\title{
OS SENTIDOS ATRIBUÍdOS À VOZ POR MULHERES APÓS A MENOPAUSA
}

\author{
Tese de Doutorado apresentada ao Departamento de \\ Saúde Materno Infantil da Faculdade de Saúde Pública \\ da Universidade de São Paulo para obtenção do Grau \\ de Doutor. \\ Área de concentração: Saúde Materno Infantil \\ Orientador: Professor Associado José Mendes Aldrighi
}

\section{SÃO PAULO}

2003 
Dedico este trabalho ao Professor Doutor João Yunes, in memorian

Menos do que poucos, apenas uma mínima parcela de pessoas, com uma profunda, particular e específica visão de mundo, é capaz de redirecionar valores e sentimentos, de estabelecer dissociações e originais vinculações, com bondade, gentileza, senso crítico, sensibilidade e idoneidade.

Foi um imenso cristal que, descobrindo o raio de sol repentinamente jorrou uma luz nova, radiante, energética, operando de maneira gradativa, transformações perenes e flexiveis ao seu redor.

Ser humano insubstituivel, que tive a graça e a honra de conviver.

A mais premente necessidade de um ser humano era tomar-se um ser humano. Clarice Lispector 
À Pontifícia Universidade Católica do Paraná (PUCPR) e ao Conselho Nacional de Desenvolvimento Científico e Tecnológico (CNPq).

À professora doutora Rosana Benini que indicou um caminho a tomar.

À professora doutora Cleybe $\mathrm{H}$. Vieira que agilizou, com carinho, os processos de mestrado e doutorado nos trâmites da PUCPR.

Às colegas e amigas do Curso de Fonoaudiologia da PUCPR que, apesar da minha ausência mantiveram o coração aberto e acolhedor ao meu retorno.

Vocês viabilizaram efetivamente a realização deste doutorado.

Aos professores da Faculdade de Saúde Pública que, com suas aulas revelaram-me um mundo pressentido (pré-sentido?), e até então, pouco vivenciado. Em especial aos professores Sabina Gotlieb, Keiko Ogura (in memorian), Augusta Alvarenga, Néia Schor, Paulo Fortes, Roberto Castellanos, Eliseu Waldmann, Délsio Natal, Oswaldo Forattini, Ana Isabel Paraguay, por cederem seu tempo e vasto conhecimento para discussões e diretrizes particulares.

Ao professor José Mendes Aldrighi, que antes de tornar-se meu orientador, estava sempre disponivel às discussões e, sobretudo, incentivava-me a pesquisar na área do Climatério.

À professora Leslie Ferreira, imensa instância de saberes, que, em primeiras palavras trocadas aceitou prontamente meu trabalho e minha pessoa.

À professora Fumika Peres, notável intelectual, com quem re-apreendi valores como a simplicidade, a humildade e a solidariedade.

Ao professor Fernando Lefévre, pelo acolhimento inicial, ainda quando eu era orientanda do professor Yunes, e pela paciência durante as discussões para compreensão da metodologia, ao longo dos anos.

Ao Dr. Francesco Viscome, por repartir seu grande conhecimento. 
À professora Silmar da Silva, responsável pelo Programa do Climatério do setor de Ginecologia da Irmandade Santa Casa de Misericórdia de Curitiba, amável e disponivel profissional, que possibilitou a ocorrência das entrevistas, servindo de elo de confiança entre as suas pacientes e a pesquisadora.

À professora Miriam Fontoura e sua aluna Priscilla Cordeiro Luparelli, do Núcleo de Produção Digital (PRODIGI), do curso de Comunicação Social da PUCPR, por prepararem em tempo recorde, com carinho e profissionalismo, o Compact Disc (CD) de acompanhamento e de apresentação da defesa da tese.

Aos muitos colegas que suportaram a minha falta de conhecimento, dividiram suas dúvidas e certezas ou conviveram durante a rotina diária (in)disciplinada.

Aos grandes amigos que cotidianamente sofreram questionamentos, exigências, solicitações, momentos de mal-humor e irritação, e, apesar de tudo, incondicionalmente apoiaram, auxiliaram, dividiram, somaram e multiplicaram carinho e respeito, fazendo com que eu crescesse pessoal e profissionalmente. Vocês estão instalados dentro do meu coração: Ana Paula, Patrícia, Kimy, Wladithe, Maria Cristina, Neide, Sueli, Luzia, Cassia, Julicristie, Paulo André, Paulo Rebelo, Gisele, Sumaia, Eneide, Nadia, Giselton, Joyce, Ideraldo, Marcia, Vera, Maisa, Simone, Daniela, Cecilia, Regina, Mirta, Mariza, Elma, Isabella, Betina, Janaina, Cintia, Maria Aparecida, Rita, Ana, Yuri, Carla, Luciana e Elba.

Às mulheres usuárias do Ambulatório da Saúde da Mulher no Climatério (ASMUC) do Centro de Saúde Escola "Geraldo de Paula Souza", que participaram do projeto piloto, oferecendo a possibilidade de aprimoramento da pesquisa.

Às mulheres do Programa da Saúde da Mulher no Climatério do Ambulatório de Ginecologia da Irmandade Santa Casa de Misericórdia do Paraná, que participaram, mesmo espantadas, da investigação que ora é apresentada.

Às bibliotecárias e funcionários da (maravilhosa) Biblioteca que, com muito profissionalismo e paciência sustentaram as minhas perquirições e imediatismo, sobretudo à Maria Lúcia, Carmem, Sueli e Márcia.

Todas as vezes que releio pormenorizadamente esta tese, reencontro cada um de vocês. A minha gratidão será eterna. 
Ao Doutor André Duprat e professora Mariuccia Lourenção que tão despojadamente confiaram em meu trabalho, cedendo material para pesquisa.

A todos os funcionários da Faculdade de Saúde Pública, e, em particular àqueles do Departamento de Saúde Materno Infantil - Iara, Leandro, Sonia, Ivany, Meirezilda - a quem considero grandes amigos.

Às funcionárias da Secretaria da Pós-Graduação - Angela, Silvia e Marilene, e do Setor de Aprimoramento - Maria Aparecida, Marcia e Renilda.

Aos funcionários do setor de Ginecologia da Irmandade Santa Casa de Misericórdia de Curitiba, especialmente à enfermeira Ana, que sem queixas admitiram minha presença anotando dados de prontuários e ocupando espaço absolutamente necessário.

Agradeço imensamente a colaboração e a as palavras de incentivo.

À minha mãe, que aos 72 anos, com muita energia, cuidou para que a infraestrutura da vida diária estivesse ao meu contento, concedendo o suporte para os meus estudos obsessivos.

À minha querida, dedicada e amorosa irmã Sonia, que esteve presente sempre que precisei, mesmo não tendo disponibilidade.

Ao meu irmão Paulo, grande, profundo e intenso interlocutor, que várias vezes, mesmo sem intenção, fez com que eu mudasse acertadamente o rumo da investigação.

Especialmente, ao Francisco José, marido dedicado, amparo incontestável, e aos filhos, Vinícius e Caroline que, ao longo de três anos toleraram a minha (benigna) ausência, mantiveram meu lugar sempre aquecido, aguardaram meu retorno, sustentando minha segurança emocional. Amo vocês por isso e por tudo que se tornaram na vida.

E, sobretudo, a Deus, que tem orientado e acompanhado meus passos ao longo de minha vida. 


\section{ÍNDICE}

Resumo

I - Problematizando o tema de pesquisa 1

1. Em busca 1

1a. Refazendo os passos 1

1b. A formação do fonoaudiólogo: a influência dos campos cientíicos 4

1c. O fonoaudiólogo na Saúde Pública 8

2. O Climatério

2a. Estabelecimento do cenário 13

2b. "Viemos do barro e à terra tornaremos": a abordagem biológica do climatério

3. A voz como âmbito de estudos para a Fonoaudiologia

3a. Voz: suas várias faces

3b. "Corpore sano": a estruturação anatômica da laringe e o processo fisiológico da voz

3c. "O crepúsculo das divas": a voz das mulheres na pós-menopausa

4. Delineamento dos pressupostos teóricos

4a. "As coisas que são vistas são transitórias, mas as coisas que não são vistas são eternas: a mirada social sobre a menopausa

4b. "E no princípio fez-se o Verbo": a função de comunicação da voz

III- Metodologia 
1a. Grounded Theory $\quad 61$

1b. Hemenêutica-dialética 64

2. Critérios e procedimentos para seleção dos sujeitos 66

3. Processo de coleta dos dados 67

4. Descrição da metodologia 69

$\begin{array}{ll}\text { IV - Resultados } & 76\end{array}$

$\begin{array}{ll}\text { V- Discussão } & 98\end{array}$

$\begin{array}{lr}\text { VI - Considerações Finais } & 127\end{array}$

Referências $\quad 131$

Anexo I - Roteiro Temático para Entrevista 1 A-Anexos

Anexo II - Instrumento de análise do Discurso do Sujeito Coletivo 2 A-Anexos

Anexo III - Termo de compromisso ético da pesquisa 79A-Anexos

Anexo IV - Consentimento livre e esclarecido 80A-Anexos

Figura 1 - Período do Climatério 16

Figura 2 - Relação entre os determinantes da pesquisa 57

Figura 3 - Sumário das etapas para aplicação do Discurso do Sujeito Coletivo 75

Quadro 1- Caracterização da população 77 


\section{RESUMO}

Machado MAMP. Os sentidos atribuidos à voz por mulheres após a menopausa. 2003 [Tese de Doutorado - Faculdade de Saúde Pública USP].

Descritores: voz, menopausa, climatério, prevenção primária, saúde ocupacional

O presente estudo evidenciou a voz humana após a menopausa, período em que a carência hormonal, em uma fração significativa da população feminina, costuma acarretar perturbações na saúde que exacerbam ou favorecem o afloramento de questões psicossociais.

A laringe, por ser um órgão hormônio-dependente, de sensivel funcionalidade, sofre a privação ovariana, apresentando alterações vocais, que se tornam mais acentuadas com a proximidade da senectude.

$O$ objetivo do estudo centrou-se na análise dos sentidos atribuidos à voz por mulheres após a menopausa.

A averiguação da relevância do tema na vida cotidiana iniciou com a coleta de dados de mulheres, em148 prontuários médicos, entre fevereiro de 2000 e outubro de 2001, no Programa de Saúde da Mulher no Climatério, do Ambulatório de Ginecologia da Santa Casa de Misericórdia de Curitiba, Paraná. Dentre a população total foram selecionadas 30 mulheres entre 48 e 59 anos, que estavam pelo menos há 12 meses em amenorréia, que não se consideravam profissionais da voz, e que foram entrevistadas com um roteiro temático constituído de questões semi-estruturadas, sendo utilizada a gravação e, posteriormente a transcrição, permitindo uma exploração em profundidade dos depoimentos, opiniões e justificativas.

A descrição, análise e interpretação foram fundamentadas pelas representações sociais, por meio do Discurso do Sujeito Coletivo, com aproximações a Hemenêutica-Dialética.

Considerando os 27 discursos coletivos estruturados, foi possivel observar representações sociais de natureza comunicacional e funcional que salientaram a voz como elemento de constituição da identidade pessoal, concebida na pertinência social.

A pesquisa sugere novas investigações fundamentadas nas Ciências Sociais, simultâneas aos estudos epidemiológicos, e a necessidade de se refletir a respeito do processo de terapêutica vocal aplicada sobre uma laringe mais fragilizada, além de priorizar uma proposta de assistência integral à mulher no climatério, com enfoque sobre a saúde da voz. 


\section{SUMMARY}

Machado MAMP. The meanings attributed to the voice by women after menopause (Os sentidos atribuídos à voz por mulheres após a menopausa). 2003 [Tese de Doutorado Faculdade de Saúde Pública USP].

Key words: voice, menopause, climateric, primary prevention, occupational health

The present work has focused on the human voice after the menopause, when the hormone depletion in a significant portion of the female population leads to health disturbances that exacerbate or favor the emergence of psychosocial issues.

Being a hormone-dependent organ presenting functional sensitivity, the larynx suffers the ovarian privation presenting vocal alterations that increase with the proximity of senectitude.

The objective of the research were focalised in analyze the meanings attributed to the voice by women after menopause.

The investigation of relevance the argument in daily life begined data from 148 medical register of women attended by gynecologists were collected between February 2000 and October 2001 in the Climacteric Women's Health Program of the Irmandade Santa Casa de Misericórdia 's Gynecology Outpatient Clinic in Curitiba - Paraná State. From the total population (148) 30 women between 48 and 59 years old that did not consider themselves as voice professionals and that were at least 12 months in amenorrhoea were selected. They were interviewed with a thematic guide of semi-structured interview questions. The interviews were recorded and transcribed permitting thoroughness examination. The description, analysis and interpretation were grounded on Social Representation, means Discourse of the Collective's Subject with approximation to Hermeneutic-Dialectics.

The resulting 27 collective discourses when social representations of communicational and functional nature were observed. These highlight the voice as an element of personal identity constitution conceived in the social sphere.

The research suggests new investigations based on Social Sciences simultaneous to the epidemiological studies. It also suggests the need to reflect on the vocal therapeutic process applied to a more frail larynx besides the prioritization of a voice health proposal with full assistance to climacteric women. 


\section{I - INTRODUÇÃO}

Sair de seu lugar e colocar-se no lugar alheio é uma viagem sem volta. Não se retorna mais à inocência do ponto de partida, porque este necessariamente se perde no caminho.

Cynthia Sarti (antropóloga) 


\section{I - INTRODUÇÃO}

\section{Em busca}

$\mathrm{Na}$ Introdução deste trabalho houve a possibilidade de analisar a experiência adquirida profissionalmente nas diversas atividades exercidas como fonoaudióloga e professora, salientando o ponto comum que suscitou as questões a respeito da menopausa. Também favoreceu problematizar os conhecimentos proporcionados pela Fonoaudiologia apontando os campos científicos mais enfatizados e a lacuna na exploração das Ciências Sociais. Tendo em vista a tarefa que se configurava, oportunizou delinear o cenário e os parâmetros que constituiriam os argumentos na estruturação da tese.

\section{1a. Refazendo os passos}

Atuando em Unidade Básica de Saúde por dez anos, pude observar amplamente, por um lado, muitas dúvidas quanto às ações fonoaudiológicas empregadas, e por outro, de forma restrita, queixas comuns de voz entre os vários segmentos atendidos.

O trabalho realizado, clínico e preventivo ao público em geral, e profilaticamente, em equipes multiprofissionais, com programas implantados para grupos mais específicos de recém-nascidos, crianças, gestantes e idosos, além da atuação junto à Perícia Médica Ocupacional, conduziram-me a suspeitas, estudos e investigações.

Como professora e supervisora do estágio em Fonoaudiologia Educacional, mantinha contato pessoal com o cotidiano extenuante do sistema 
educativo. As dúvidas dos(as) estagiários(as) serviram de mote para a reflexão. As contínuas remodelagens das atividades para adequar ao tempo sempre muito escasso dos professores, incomodava imensamente. O insuficiente envolvimento e a reduzida conscientização quanto aos cuidados vocais, chegava, às vezes, a provocar revolta aos grupos de alunos.

As ações em consultório particular, e em atividades como cursos e orientações aos professores e professoras de escolas municipais, do pré-escolar e ensino fundamental, também contribuíram para o surgimento de inquietações e incertezas.

Essas experiências conduziram à reflexão e dentre as abundantes questões que me intrigaram, uma delas era o aumento de sintomatologia vocal entre mulheres em torno dos 50 anos, preferencialmente das professoras, pois apresentavam maior demanda no serviço público e privado. Os sinais apresentados levavam a crer, em primeiro plano, que o desgaste genérico ocasionado ao longo do tempo de serviço fosse o principal responsável.

Em literatura, a observação dos autores voltava-se para o envelhecimento das estruturas laríngeas na senescência, o mau uso ou abuso vocal e a influência hormonal na sua fisiologia, contudo, as explicações organicistas me aparentavam pouco aprofundadas e não de todo convincentes (SATALOFF e col. 1998; LE HUCHE e ALLAL 1999, HUNGRIA 2000b), pois não distinguiam a repercussão de cada elemento nas alterações e pouco esclareciam, isoladamente, o processo de atuação dos esteróides na voz.

A análise simultânea de todo esses elementos reforçava a minha primeira hipótese de uso excessivo das estruturas do trato vocal e até o estresse emocional. Porém, não levava em conta os múltiplos fatores sociais que envolvem 
habilidades de relacionamento e sequer aqueles decorrentes da implantação e mudanças de políticas na organização do trabalho, das condições trabalhistas e de salários, que sobrecarregam a vida diária desses profissionais (PENTEADO e PEREIRA 1996). Comparada aos problemas abrangentes, desde de ausência de recursos materiais e ambientais adequados até a escassez de valorização do papel exercido pelo professor e de incentivo para uma carreira docente, a questão 'saúde vocal' talvez fique difusa e minimizada.

Aprovada como doutoranda na Faculdade de Saúde Pública, passei a freqüentar uma disciplina voltada aos estudos multiprofissionais da mulher no climatério que me possibilitou entrever o relacionamento das queixas comuns entre os vários segmentos que relatavam mudanças vocais em períodos críticos de suas vidas. Portanto, a hipótese desencadeada anteriormente - exercer a função de professor e trazer mais queixas vocais, por volta dos 50 anos - era falsa. Enfim, o vínculo deveria ser constituído articulando a fase da vida da mulher, considerando a própria perda dos hormônios sexuais, suas conseqüências no entorno psicossocial e não apenas a ocupação, freqüência de uso e processo de envelhecimento.

Algumas reflexões passaram a ser investigadas sob as premissas das diversas disciplinas e múltiplas perspectivas dos professores com os quais mantinina contato propiciado pela convivência diária na Universidade. A expectativa centrouse na possibilidade de que minhas primeiras inquietações pudessem ser respondidas (ou mais questionadas) se o tema "voz" fosse tomado sob um enfoque da Saúde Pública.

Desse modo, sendo o objeto inserido em um grande dominio de conhecimentos, em um campo científico organizado tanto para assistência quanto para pesquisa, e focalizado no binômio saúde e doença, com explanação mais 
integrada sob a ótica das Ciências Sociais, foram se delineando questões pontuais a respeito da relação voz e pós-menopausa. Nesse sentido, as alterações da fonação produzidas por um esgotamento da função esteróidica ocorreriam apenas pela privação hormonal? O desequilíbrio genérico orgânico e psicossocial possuiria responsabilidades? Seriam perceptíveis pela maioria das mulheres? Quais relações as mulheres produziriam entre voz e identidade pessoal e social? E entre voz e menopausa? Estas foram algumas das proposições singulares que foram se revelando no decorrer da investigação.

Após um projeto piloto (MACHADO e YUNES 2001) centrou-se, então, na hipótese de que mulheres, não-profissionais da voz, têm a possibilidade de notar as transformações ocorridas no processo vocal de pós-menopausa, e que dão sentidos a esses movimentos. Aproximar-me de uma acepção social que considerasse a linguagem e a comunicação na vida cotidiana, em muito contribuiu para a compreensão deste fenômeno.

Todavia, necessitei retroceder para analisar e administrar o conhecimento adquirido e desenvolvido durante a minha formação como fonoaudióloga e professora, no decorrer da carreira profissional, para poder pesquisar dominada por estas noções.

\section{1b. A formação do fonoaudiólogo: a influência dos campos científicos}

O hibridismo da Fonoaudiologia obriga a visita aos múltiplos setores de atualização das fontes cientificas, e no Brasil, a sua história ímpar assinala o desenvolvimento crescente ao longo de seus 50 anos (VIEIRA e col. 2000). No presente, várias instituições oferecem especialidades e cursos de pós-graduação, 
sendo a Fonoaudiologia apontada por revistas especializadas ou de assuntos gerais, como uma das profissões do futuro, pois está relacionada aos cuidados de saúde que aumentam a longevidade, importante índice do atual perfil epidemiológico da sociedade, e aos processos vigentes de comunicação deste mundo globalizado.

Na formação do fonoaudiólogo a influência das Ciências Biológicas, geralmente preponderante, como a Medicina, Odontologia e suas diversas especialidades, tende a conduzir o profissional para pesquisa e atuação sobre as estruturas e a funcionalidade da audição, voz, linguagem oral e escrita, abrangendo a fala e as funções estomatognáticas em seus diversos âmbitos de ocorrência atípica. Aliás, nessa abordagem, sem os devidos questionamentos, os parâmetros de anomalia são assumidos apenas sob um ponto de vista orgânico e funcional, fundamentados pela Biologia, Fisiologia e/ou Neurologia.

Sob a ascendência das Ciências Humanas, a Lingüística, a Psicologia e a Pedagogia alicerçam as posições de pesquisa fonoaudiológica com abordagens das diversas linhas explicativas da linguagem oral e escrita, apoiadas ou não por fundamentos da Psicanálise e/ou da Antropologia, mais recentemente. A ressalva justifica-se no enfoque terapêutico que nem sempre apresenta coerência aos modelos elucidativos adotados.

As investigações sustentadas pelas Ciências Sociais (tomadas aqui no seu sentido amplo, com uma natureza de compartilhamento de domínios e não como sinônimo de Sociologia, de acordo com ADORNO 1998), são relativamente poucas e somente alguns profissionais enfatizam esta perspectiva. Dentre eles, FERREIRA (1977, 1985, 1988, 1991, 1995, 1998, 2000), ao longo de toda sua trajetória como pesquisadora, vem indagando situações fonoaudiológicas voltadas aos grupos, comunidades e instituições. Ao mesmo tempo MAIA (1987/1993/1997), 
FIGUEIREDO NETO (1988), ANDRADE (1991), MENDES (1994), MASSON (1995) e LEWIS (1996) buscam trazer à luz os pressupostos sociais teóricos apontando a exigência de uma visão mais íntegra da Fonoaudiologia.

No entanto, a discussão fundamentada por concepções das Ciências Sociais sobre as ações de interferência no processo de aquisição e no uso apropriado das capacidades nas áreas de audição, voz, linguagem e motricidade oral, ainda são estudos esporádicos, solitários e recentes como de FREIRE (1992), IÓRIO (1999), LOPES (2001).

Não obstante, a Fonoaudiologia abarca um extenso universo desde o recém-nascido até 0 idoso, e grande parte de suas sub-segmentações e categorizações, sejam estas realizadas por sintomatologia, faixa etária, profissão ou outra qualidade comum eleita, que justificaria a exploração em um âmbito social.

O predomínio das pesquisas organicistas, centradas em metodologias positivistas e quantitativas, provavelmente deveu-se à busca de cientificidade, tendo os parâmetros estabelecidos pelas ciências enfatizadas na formação do profissional ou aquelas perante as quais a Fonoaudiologia se submetia na tentativa de aprovação e reconhecimento.

O positivismo de Comte, reagindo às questões metafísicas do racionalismo cartesiano e do idealismo alemão, propõe o compartilhamento das mesmas condições de pesquisa e análise para todas as ciências (HAGUETTE 2000), negando "o caráter racional a todas as formas de conhecimento que não se pautarem pelos seus princípios epistemológicos e pelas suas regras metodológicas" (SANTOS 1993, p.10). 
Porém, como poderiam as ciências humanas e sociais investigarem sob os conceitos e pressupostos de uma metodologia indutiva, com ponto de vista empirista e partindo de uma observação e descrição objetivas, sem excluir ou marginalizar o sujeito?

HABERMAS (1984), entre muitos autores, criticou o posicionamento distinguindo ciências naturais e humanas (nesta última incluindo as ciências sociais) apontando que os interesses cognitivos de ambas são característicos, exigindo a elaboração de metodologias diferenciadas. Salienta que, às ciências sociais, é facultada a capacidade de inferir dados teóricos com fins explicativos, e a possibilidade de interpretá-los. No entanto, SANTOS (1995, p.24) questiona, como um exercício de perplexidade produtiva para identificar os desafios diante das circunstâncias da pós-modernidade, se "em condições de aceleração da história como as que vivemos hoje é possível por a realidade no seu lugar sem correr o risco de criar conceitos e teorias fora do lugar?".

Ora, perpassar os conhecimentos das diversas áreas não é tarefa fácil, pois, o entrelaçamento e a permeabilidade entre eles, segundo FREIRE (1992), exigem que se formem fios sutis de condução ao diálogo efetivo ou resvalarão em uma transferência direta infeliz e ineficiente para a prática do profissional. A potencialidade fica comprometida diante dos equívocos, tais como incorporação dos conceitos sem o devido rigor, a falsa aparência da transitividade da polissemia das noções comuns e a substituição das análises fragmentadas por sínteses simplificadoras, conforme MINAYO-GOMES e THEDIM-COSTA (1997)

A Fonoaudiologia, devedora de tantos saberes e lugar promissor de abrangência de muitos outros, pela complexidade que o cuidar do ser humano 
exibe, arrisca-se a atuar em espaços sociais mantendo sua prática centralizada no aspecto clínico unidirecional e na noção assimétrica de poder e conhecimento.

\section{1c. O fonoaudiólogo na Saúde Pública}

Apesar de a Fonoaudiologia ter nascido social, na Educação, e se tomado clínica e individualizante no decorrer de sua história, na Saúde (BERBERIAN 1993), a inserção do fonoaudiólogo em Unidades de Saúde Pública do Sistema Único de Saúde (SUS) deu-se sem muita clareza da necessidade do profissional nesse campo de ação. As circunstâncias dificultaram as situações de ensino e principalmente a introdução de disciplinas na formação do aluno, talvez, também, porque uma parte do corpo docente das Instituições de Ensino não vislumbrasse essa linha de trabalho. Por motivos aparentes, isto "concorreu para o desconhecimento do contexto histórico geral da saúde pública e da clientela a quem ela é tradicionalmente oferecida e retardou a experiência junto aos serviços públicos", segundo FREIRE (1992).

o produto constituiu-se de um espaço vazio entre a teoria e a prática, que resultou, por um lado na falta de políticas voltadas para a implantação dos serviços fonoaudiológicos, e por outro lado, na dificuldade do profissional repensar o seu papel e os conceitos de atuação (FREIRE 1992). Genericamente, essas ações são caracterizadas por atividades educativas e de tentativas de inserção da população em comportamentos e valores pertencentes à sociedade que detém o poder, canibalizando o conhecimento popular.

Aliás, sobre a prática antropofágica das culturas minoritárias SANTOS (1997, p.121), em sua orientação metodológica para tornar possivel a comunicação e a cumplicidade, propõe a hermenêutica diatópica, "um exercício de reciprocidade 
entre culturas que consiste em transformar as premissas de argumentação de uma dada cultura em argumentos inteligíveis e criveis noutra cultura".

LOPES (2001), corroborando com o autor anteriormente citado, introduz a questão - "o que temos a aprender com a Saúde Pública?" - e responde, atentando para a necessidade de se pensar em uma Fonoaudiologia Social reflexiva e que dialogue com a população para (des)construir o cotidiano.

Na Saúde Pública, as campanhas de prevenção e os programas educativos, voltados às doenças laríngeas e de distúrbios vocais, recebem pouca aderência, mesmo de grupos profissionais que utilizam a voz como principal instrumento de trabalho.

Para ilustrar, toma-se o exemplo dos professores (PENTEADO e PEREIRA 1996; SCALCO e col. 1996), ou das educadoras de creche (SIMÕES e col. 2000), que percebem a instalação das disfonias ou o seu agravo, convivem com o problema e consideram desnecessárias as intervenções especializadas. Provavelmente, este posicionamento deva-se à habituação das condições de trabalho com qualidade de vida reduzida, à falta de interpretação da saúde como um direito social (PENTEADO e PEREIRA 1996), ou por não assumirem a voz como um instrumento de trabalho (VIOLA e col. 2000), naturalizando a situação.

Contudo, as atividades propostas também não são fundamentadas por sịgnificados da própria população. Apresentam quase sempre um caráter técnico e de demanda dos profissionais envolvidos, os quais, muitas vezes, não têm esclarecimentos necessários sobre os modos de viver, as experiências sociais, os sentidos imputados a estas vivências, conhecimentos de extrema importância para qualquer intervenção, conforme MORIN (2000). 
Enquanto nega ou coloca à margem o poder da ancestralidade na transmissão das informações àquelas pessoas que procuram os serviços de saúde ou à comunidade que se pretende atingir, inviabiliza ou, ao menos, dificulta a transformação do hábito em atitude reflexiva.

Aparentemente, em muitas ocasiões, a ação do fonoaudiólogo em grupos comunitários é realizada sem os pressupostos sociais necessários de coletividade, apenas adotando-a como uma soma de individuos, não alcançando, com isso, uma visão de totalidade.

Assim, o processo de conhecimento torna-se unilateral ou lacunar, e MARTINELLI (1999) destaca como os dados obtidos acabam não sendo geradores dos avanços da prática, e insuficientes para a possibilidade de sua construção coletiva.

Com a visão futurística de relacionar teoria e prática com questões do âmbito da saúde pública, a Resolução que institui as Diretrizes Curriculares Nacionais estabelecidas pela Câmara de Educação Superior do Conselho Nacional de Educação para organização, desenvolvimento e avaliação dos projetos pedagógicos dos Cursos de Graduação em Fonoaudiologia das Instituições do Sistema de Ensino Superior (2002) reconheceu o valor na profissão de uma "formação generalista, humanista, crítica e reflexiva" que capacita o "egresso/profissional Fonoaudiólogo [...] para atuar pautado em princípios éticos, no campo clínico-terapêutico e preventivo das práticas fonoaudiológicas". A primeira competência e habilidade, entre outras estabelecidas, é a de atenção à saúde com "ações de prevenção, promoção, proteção e reabilitação da saúde, tanto em nível individual quanto coletivo", contemplando no currículo do Curso a direção para o conhecimento e a preservação "das culturas nacionais, regionais, 
internacionais e históricas, em um contexto de pluralismo e diversidade cultural", mantendo a coerência para uma atuação pautada em principios éticos.

Atualmente, para CHUN e col. (2000), a grande maioria das escolas de Fonoaudiologia incorporou conhecimentos e estágios que contemplam, além das ações curativas, a atuação preventiva e descentralizada dos distúrbios, enfatizando a promoção de saúde e a proteção específica "procurando uma maior compreensão das relações homem/mundo e do processo saúde/doença" (p.80).

Năo obstante, restam questões centrais: pela formação, vivência e investimento até muito recentemente no campo clínico-terapêutico, estarão os professores dos cursos de Fonoaudiologia aptos a desenvolverem essas habilidades em seus alunos? Estarão sendo capazes de preparar os profissionais para enfrentarem o mercado contemporâneo de trabalho? Estarão conseguindo responder às exigências e desafios que a conturbação e as transformações da contemporaneidade apresentam aos indivíduos, profissionais e cidadãos?

MORIN (2000) discute essas questões quando evidencia os saberes necessários à educação do futuro e aponta a aprendizagem para lidar com a verdade ilusória e fugaz, as transformações da realidade, as incertezas e imprevistos da contemporaneidade, por meio das competências de compreensão e tolerância entre os diferentes e os iguais, do desenvolvimento da consciência e ética do gênero humano, conduzindo ao sentido de pertencimento ao universo, isto é, ao reconhecimento do indivíduo como parte da sociedade e parte da espécie humana.

Exceção à parte, na área profissional, uma das poucas investigações sobre a percepção e capacidade de julgamento da qualidade vocal, foi realizada com alunos de Fonoaudiologia, fonoaudiólogos e leigos. Os resultados obtidos apresentaram-se semelhantes, apesar de cada grupo utilizar recursos diferenciados 
de avaliação (GRILLO e col. 2000). Embora as habilidades perceptuais dos leigos sejam menos flexiveis, com padrões semelhantes utilizados para análise das amostras, esses dados sugerem a atenção conferida ao processo vocal pela população, com uma lógica própria imputada.

Sob os conceitos de Saúde Pública, tomada aqui sob seu sentido de coletivo, de pluralidade e diversidade, essa atribuição justificaria o empreendimento para conhecer não apenas a demanda, mas também o pensamento e o saber cultural e cotidiano de grupos particulares da sociedade.

A atuação e investigação no campo da Saúde Pública talvez estejam exigindo uma nova postura criativa, social e menos matemática, ou de intersecção das epistemologias naturais e sociais nas abordagens dos fenômenos fonoaudiológicos, sejam intermediadas por ações preventivas em seus diversos níveis (LEAVELL e CLARK 1976), sejam permeadas por reflexão (com o significado de reciprocidade e de ponderação) de todo o conjunto de relação entre profissionais e comunidade, entre o senso comum e o conhecimento científico.

O climatério, pano de fundo neste trabalho, apresenta algumas especificidades pouco conhecidas à grande maioria dos profissionais de saúde, em especial nos serviços públicos e/ou coletivos, principalmente em se tratando de algo tão particular quanto o objeto de pesquisa.

Por conseguinte, passam a ser explorados os assuntos climatério, menopausa, voz e voz da mulher após a menopausa, situando-os em umạ perspectiva descritiva biofisiológica, para, em seguida, estabelecerem-se os pressupostos teóricos que norteiam esta investigação. 


\section{O Climatério}

\section{2a. Estabelecimento do cenário}

Em uma análise de problemas específicos de saúde no Brasil, por grupos de população, a Organização Panamericana de Assistência à Saúde da Organização Mundial de Saúde (1998) detectou que "as informações disponiveis sobre as condições de saúde da mulher se referem, sobretudo, a aspectos reprodutivos", o que exclui o período de pós-menopausa, enquanto que no grupo de idosos as internações corresponderam, em 1995, a 17\% de um total de 12,7 milhões. Esses dados revelam um alto consumo de recursos (nesse caso, equivalente a $20,8 \%$ do total de hospitalizações em 1995) e a existência de um hiato nas pesquisas em saúde do adulto, exatamente na transição entre os dois grupos, que poderia estar reduzindo os custos com a terceira idade.

\section{2b. "Viemos do barro e à terra tornaremos": a abordagem biológica do climatério}

O senhor escute meu coração, segure meu puiso. O senhor avista os meus cabelos brancos... Viver - não é? - é muito perigoso. João Guimarães Rosa (escritor)

Partindo de uma acepção biológica, o climatério é conceituado como o período de modificação entre a função completa do ovário e seu estado de repouso, ou seja, representa a transição da vida reprodutiva para a pós-reprodutiva (SÁ e PETRACCO 2001).

KASE (1989) explica o processo fisiológico que ocorre no climatério, observando que por volta dos 40 anos o ciclo menstrual muda em relação ao tempo 
e ao funcionamento, quando os níveis de hormônios ovarianos reduzem-se de forma lenta e gradativa, promovendo alterações menstruais que culminam com a última menstruação ao redor dos 50 anos, denominada menopausa (FONSECA e col.1985).

A rigor, a unidade reprodutora básica do ovário é o folículo primário, que tem a quantidade estabelecida no período fetal e a atresia é iniciada ainda na vida intra-uterina, sendo que, de 6 a 8 milhões de células germinativas nesta fase apresenta-se por volta de dois a três milhões na recém-nascida, trezentos a quatrocentos mil na púbere, aproximadamente oito mil na adulta até 40 anos e algumas poucas unidades na mulher de 50 - 60 anos (MCARTHUR 1981). Durante toda a vida, somente cerca de quatrocentos desses folículos alcançam o desenvolvimento completo, liberando o ovócito (HALBE 2000b; GOLDFIEN e MONROE 2000).

$\mathrm{Na}$ transição menopausal, aparentemente, os folículos que permaneceram nos ovários tornam-se menos sensiveis à função das gonadotropinas. Isto contribui para o aumento progressivo do hormônio folicular estimulante (FSH) e a produção reduzida de estrógenos e progestogênios, surgindo, então, os lapsos na ciclicidade e a diminuição nos intervalos entre os períodos de menstruação (GOLDFIEN e MONROE 2000). As células do estroma ovariano produzem mais androstenediona e mínimas quantidades de estrogênio, respondendo a uma estimulação do hormônio luteinizante (LH), segundo SÁ e PETRACCO (2001).

Assim, a produção média do estradiol restringe-se, e o circulante encontrado provém da estrona convertida perifericamente da androstenediona. A escala dessa conversão correlaciona-se com o peso corporal incidindo na 
capacidade das células adiposas de englobar e aromatizar andrógenos em taxas eficientes, de acordo com HALBE (2000b).

Por seu turno, o nível de progesterona diminui sensivelmente e tem origem na supra-renal. Por assim dizer, a síntese e a secreção dos hormônios ovarianos não são mais suficientes para proliferar uma quantidade do endométrio que produza menstruação, conduzindo a mulher a atingir a menopausa. Nesta fase a secreção de testosterona não muda, aparentemente porque o estroma do ovário continua estimulando o hormônio luteinizante (GOLDFIEN e MONROE 2000).

Entretanto, com o passar dos anos, o estroma ovariano primeiramente, e depois a contribuição dos precursores corticais da supra-renal tornam-se inadequados e insuficientes para manter os tecidos sexuais secundários, seguindose a atrofia dos órgãos hormônio-dependentes, peculiar da senectude, conforme KASE (1989).

Assim, tendo em vista as concepções referidas e o conhecimento da atuação dos hormônios, alguns autores dividem o período do climatério em três fases - pré, peri e pós menopausa - mantendo a última menstruação como ponto de referência (TRIEN 1994; TOLOSA 1997). Outros autores preferem estabelecer o início do climatério em uma faixa de idade entre 35 - 40 anos (transição menopausal) e o final (pós-menopausa) entre 60 - 65 anos, sem muita unanimidade (HEGG e col. 1994; NAHOUM e SIMÕES 1989; ALDRIGHI e PIRES 2001) devido à freqüência das perturbações menstruais, e a idade de menopausa girando em torno dos 50 anos (FONSECA e col. 1985; KASE 1989; HALBE 2000b; ALDRIGHI e PIRES 2001). 
Figura 1: Período do Climatério
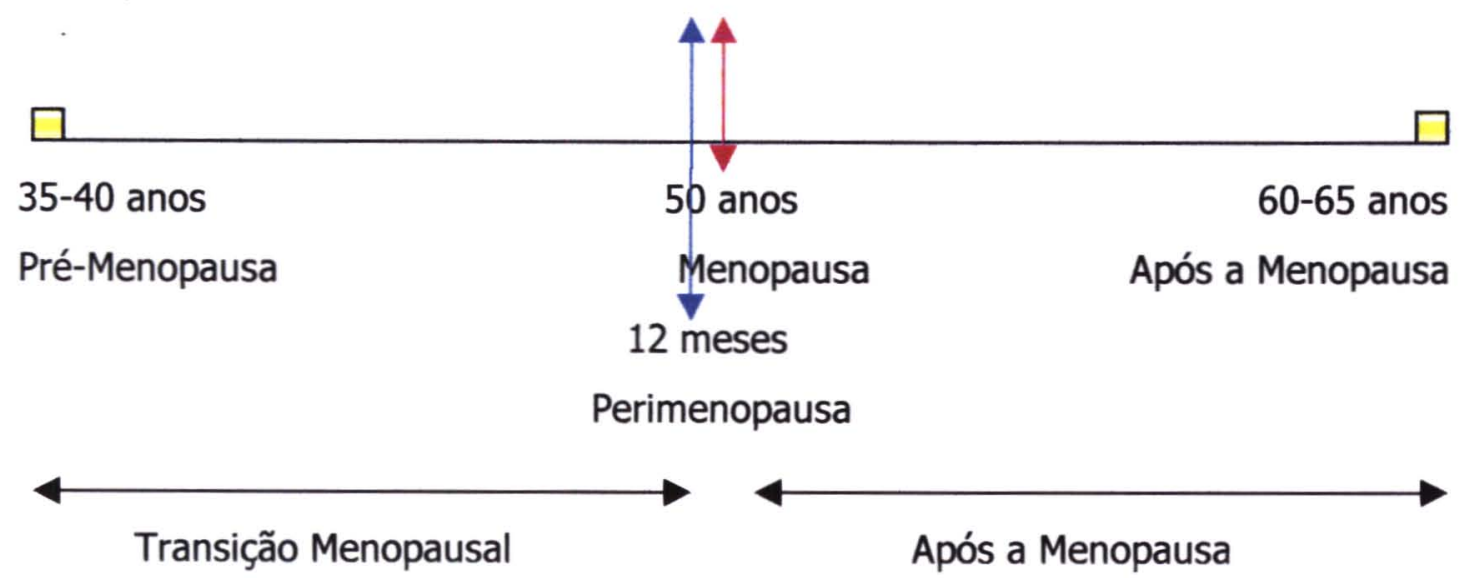

Apesar de ser um fenômeno natural, aparentemente a evolução dos sintomas, como o aumento da vulnerabilidade cardiovascular e perda da massa óssea (osteoporose), flacidez muscular generalizada e progressiva, ressecamento da pele e da mucosa vaginal, constituem-se em sérias repercussões na saúde da mulher e na qualidade de vida após a menopausa (ALDRIGHI 1996).

As queixas de cansaço, nervosismo, cefaléia, insônia, irritabilidade, dor articular e muscular, tontura, palpitação, formigamento, entre outras, surgem com certa regularidade, segundo KASE (1989).

Para ALDRIGHI e PIRES (2001), polêmicas são levantadas a respeito de conseqüências como aceleramento da doença de Alzheimer, susceptibilidade ao câncer cólon-retal e os fatores de risco que se apresentam na terapia de reposição hormonal para o endométrio e a mama.

Nessa época, portanto, todas as interfaces da vivência humana são condicionalmente afetadas, e a partir de um marco biológico e natural do desenvolvimento, a saúde da mulher é alterada significativa e negativamente (FEBRASGO 1995). 
Vemos, então, que a menopausa é formalmente caracterizada pela falência dos ovários. O desequilibrio entre o sistema hipotálamo-hipófise-ovário e o processo de envelhecimento que se instala lenta, progressiva e inexoravelmente no decorrer de toda a vida, e que agora está mais acentuado, transformam a relação entre o sistema endócrino, os alvos de atuação dos hormônios, todo o metabolismo orgânico e a dinâmica sistêmica corporal em uma atividade mais frágil, mais sujeita a falhas e debilidades.

Assim, são observados os agravos em órgãos como o figado que, dentre muitas atividades, realiza a formação de glicose (e em conjunto ao pâncreas regulam a glicemia sistêmica) e metaboliza inclusive os androgênios convertendo uma porção em estrona. Instalam-se alterações no metabolismo dos rins, que retêm a água e governam a pressão sangüínea. Surgem os transtornos dos mediadores responsáveis por sinapses nervosas, da imunidade orgânica e de todo o sistema genital urinário. O processo metabólico das glândulas tireóide e paratireóide, incluindo a absorção e assimilação do cálcio, tornam-se comprovadamente afetados. Institui-se uma nova fase de debilidades e da necessidade de cuidados, em grande parte medicamentosa na Medicina ocidental, para manter-se a qualidade da saúde.

A partir dessas noções, restam questões tais como: estaria sendo refletido na atividade vocal o agravamento da saúde feminina? Ou, conhecendo a natureza mais complexa da produção da voz, há como salientar pontos básicos que alavanquem ações necessárias individuais e coletivas, para impedir ou amenizar a possivel instalação de alterações prejudiciais? 


\section{A voz como âmbito de estudos para a Fonoaudiologia}

\section{3a. Voz: suas várias faces}

A voz é o veículo de nossa inter-relação, de comunicação, um meio de atingir o outro. Nada nos assusta mais do que encontrarmos alguém que fala sozinho pelas ruas. Imediatamente $o$ consideramos louco, única $e$ exclusivamente porque não há o outro. E a voz só existe porque existe 0 outro.

Mara Behlau (fonoaudióloga)

Durante o século $\chi \chi$, a intensidade das duas grandes guerras, dos conflitos que espocaram em vários locais do globo terrestre, incluindo a violência das grandes cidades, da popularização da indústria automobilística, do uso indiscriminado do tabaco e de produtos inalados ou ingeridos, voluntária ou involuntariamente, renderam um farto material de estudo. Os resultados foram as intervenções sobre a laringe (e em todo o corpo humano), com uma tecnologia, invasiva ou não, cada vez mais sofisticada, e a explanação acurada da dinâmica vacal.

Com o surgimento dos novos meios de comunicação originaram-se outras profissões em que a oralidade ganhou maior importância e, segundo SOUZA e FERREIRA $(2000$, p.1), "... nunca se precisou tanto da voz como neste século...".

O emprego dos conceitos dos modelos da física geral atual e da física acústica, e noções da Inteligência Artificial aplicados às medidas das características vocais e suas propriedades, analisam, de forma cada vez mais minuciosas, as implicações entre voz e fala, e as relações e envolvimento com o canto (CAMARGO 1999). 
A tendência quantificadora e de aperfeiçoamento da tecnologia, incluindo os conhecimentos da Genética, parece ser também a proposta desse início de século XXI (TITZE 1995). As idas e vindas de um campo funcional ao outro, da teoria à prática e os recursos tecnológicos, especializaram e refinaram as técnicas empregadas, que mesmo assim, muitas vezes são excedidas pelas condições psiquicas que interferem, influenciam e são denunciadas em um processo comunicativo, exigente da formação de um eu pós-convencional (HALL 1999).

Os conhecimentos descontínuos adquiridos ao longo da história da humanidade possibilitaram que fossem utilizadas as intervenções cirúrgicas ou terapêuticas, alcançando a minudência do estabelecimento de critérios para se criarem sistemas de segurança na área da Internet (SÓRIA 2002) empregando a voz humana. Assim, tomadas ou retomadas de habilidades pessoais resultaram da recuperação dos pacientes com paralisia de prega vocal, ou do estabelecimento da voz nas exéreses de laringe. Outras decorreram de procedimentos voltados para as situações sócio-culturais atuais que afetam as questões de gênero, como cirurgias de redução do tamanho das pregas vocais para gerar frequiências mais agudas na voz dos transexuais, em alguns paises que aprovam a mudança de sexo legalmente (GIELOW 1996). E ainda, aptidões estéticas e ocupacionais são desenvolvidas pelo refinamento na quantificação das características de uma voz ideal, por exemplo, para o treino de um cantor (TITZE 1995).

Vemos, então, que os avanços se deram principalmente pela intenção de aprimorar a ação comunicativa, conduzindo ao entrelaçamento dos enfoques estético, ocupacional e curativo. Desse modo, em consonância a HABERMAS (1997, p.93), constata-se que "o poder comunicativo só se forma naqueles espaços 
públicos que produzem relações intersubjetivas na base do reconhecimento mútuo e que possibilitam o uso das liberdades comunicativas".

Conhecer como ocorrem as mudanças na voz e como reagem as pessoas implicadas pode esclarecer também processos relativos e especificos da senescência vocal, e trazer à luz dados que poderão servir para diagnóstico preventivo de doenças particulares das diversas faixas etárias, ou à abertura de novas pesquisas sobre a temática deste trabalho.

No Brasil, a voz vem sendo pesquisada principalmente sob uma perspectiva biológica por profissionais reconhecidos, em especial médicos e fonoaudiólogos. Apesar de todos apontarem as interfaces psicológica e sociológica, poucos discorrem sobre essas pautas, e quase nada se sabe do que pensa a população a respeito da relação do sujeito com sua própria voz e com a voz do outro, isto é, dos significados atribuídos à voz como identidade pessoal e social.

\section{3b. "Corpore sano": a estruturação anatômica da laringe e o processo fisiológico da voz}

Se há a possibilidade de distinção dessas interfaces, para melhor discutir suas particularidades, o principal objetivo passa a ser, nesse momento, resgatar uma imagem biofuncional garantindo a apreensão clara do interrelacionamento dos diversos aspectos que compõem a produção vocal nessa perspectiva.

Dessa forma, pode-se dizer que, do ponto de vista fisiológico, a voz é denominada como o som produzido pela vibração das pregas vocais à passagem do ar no percurso laringeo e modificado pelas cavidades de ressonância supra e infra glóticas (BEHLAU e PONTES 1995). Ao longo dos anos, várias correntes explicativas 
da função fonatória concorreram entre si, ou se complementaram, e progressivamente tornaram possivel o refinamento na compreensão dos numerosos e complexos fatores que se relacionam na funcionalidade da laringe.

Atualmente, é possivel reconhecer que a voz é produzida pela passagem do fluxo aéreo em alta velocidade, provocando uma pressão negativa ao criar um vácuo parcial entre as pregas vocais que propicia o contato inicial por sucção, denominado fenômeno de Bernouilli, e pela retração elástica que opõe-se, conduzindo a um retorno à posição inicial (CAMARGO 1999; HUNGRIA 2000b). O resultado harmônico e equilibrado entre essas duas forças concorrentes é considerado, pelos estudiosos da voz, o centro básico para a higidez do trato vocal e para o estabelecimento da eufonia, isto é, da produção de sons que são agradáveis aos ouvidos (BEHLAU e PONTES 1996; BLOCH 2000).

Durante a constituição embriológica (MÜLLER 1996; HENICK e SÁTALOFF 2002), até a senescência, a formação anatômica e a composição histológica da laringe sofrem alterações que possibilitam uma fisiologia apropriada aos respectivos períodos e que resulta em uma voz adequada para cada idade, própria para cada época da vida (BEHLAU 1995; LE HUCHE e ALLALI 1999; SATALOFF 1997).

Assim, a sua posição, forma e tamanho interferem na função vital que exerce e na amplificação, intensidade e altura sonora; os ligamentos e articulações estabelecem os movimentos funcionais, alguns bastante complexos, por meio de força muscular, permitindo ajustes no calibre e no comprimento da laringe, e em especial das pregas vocais, atuando sobre a qualidade de fonação (BEHLAU 1995; MÜLLER 1996; COLTON E CASPER 1996; SATALOFF 1997; LE HUCHE E ALLALI 1999; HUNGRIA 2000a). 
A histologia aponta que a mucosa revestida por epitélio cilíndrico ciliado vibrátil e lâmina própria, com o cório não diferenciado que o une firmemente às paredes da laringe, é especializada no processo respiratório em toda sua extensão. Contudo, nas pregas vocais, modifica-se para epitélio malpigiano estratificado e pavimentoso, capaz de suportar melhor os micro-traumatismos cotidianos (GUYTON e HALL 1998), apesar de não-coriáceo (LE HUCHE e ALLALI 1999), com glândulas secretoras e de circulação linfática diminuida.

Dé acordo com HIRANO (1998), as pregas vocais não são uniformes, mas formadas por uma estrutura de cinco camadas. A primeira e mais externa é o epitélio. Abaixo dele há a lâmina própria, dividida em três camadas: a superficial, formada pelo espaço de Reinke, em que o tecido conjuntivo frouxo permite uma movimentação variada que participa da ondulação vibratória, e, junto com 0 epitélio, compõe a cobertura; a camada de transição intermediária, que consiste principalmente de fibras elásticas; e a profunda, composta primeiramente de fibras de colágeno. As duas últimas camadas conformam o ligamento vocal, que na laringe infantil apresenta-se imaturo (BEHLAU 1995) ou, segundo LE HUCHE e ALLALI (1999, p.104) "só aparece entre um e quatro anos". Sob a lâmina própria está o músculo vocal, o corpo vocal propriamente dito, muito flexível, constituído por múltiplas camadas com propriedades mecânicas diferentes, com grande capacidade de vibração.

Conforme ABITBOL e ABITBOL (1998), ABITBOL e col. (1999), todo revestimento do trato vocal é extremamente suscetível às variações e, essencialmente, à privação dos hormônios sexuais femininos.

A sensibilidade hormonal dos receptores de estrogênio disseminados nạ laringe, semelhantes aos dos órgãos sexuais (ABITBOL e ABITBOL 1998), ocorre 
por meio de dois mecanismos básicos, segundo GUYTON (1986): a formação do segundo mensageiro (ativação da molécula AMP cíclica - acetato de medroxiprogesterona) que inicia múltiplas funções celulares, e a ativação dos genęs que enceta a função celular especifica.

Os átomos esteróide 18 carbono formam a base molecular para a sensibilização aos esteróides na laringe (ABITBOL 2001). Assim, para GUYTON (1986), o processo ocorre em função dos esteróides serem formados por estruturas semelhantes ao colesterol e os receptores, proteinas grandes, encontrarem-se no citoplasma das células. Na sinapse há a indução da síntese de proteína na célulaaivo que, atuando como enzimas, proteínas de transporte ou proteinas estruturais, ațivam outras funções celulares, penetram no citoplasma celular, ligando-se à proteina receptora especifica.

Essa constituição é transportada até o núcleo e as novas combinações ativarão os genes traduzindo o processo específico para o mensageiro ácido ribonucleico (RNA), que se difunde no citoplasma promovendo a formação de outras proteinas no ribossoma.

Dessa forma, a privação hormonal trará os mesmos prejuízos à mucosa laríngea que podem ser encontrados nos tecidos dos órgãos sexuais femininos, como desidratação, atrofia muscular, modificação da espessura, perda da elasticidade das fibras, dentre outras, assunto explanado mais detalhadamente adiante.

O requintado e complexo empréstimo do sistema digestório e respiratório, realizado para fonação, é coordenado pelo sistema nervoso central, nas suas diversas funções (respiratória, fonatória, esfincteriana). Nesse processo é auxiliado pela inervação autônoma, vascularização e circulação linfática, 
responsáveis pelo aporte sangüíneo e de linfócitos, respectivamente, importantes para a manutenção e lubrificação dos tecidos, e imunização sistêmica e local. As secreções glandulares sustentam uma cota apreciável de responsabilidade em todo o funcionamento otimizado do tubo laríngeo (GUYTON e HALL 1998), mantendo as condições de excelência da respiração e da fonação.

Também é favorecido pelo sistema auditivo, com um processo de ajustes entre o som produzido e aquele que se faz necessário (SATALOFF 1998a). Quando se trata de voz, fica impossível fugir da relação básica entre som e audição, pois a voz humana é captada como sons complexos, isto é, ondas sonoras formadas por mais de uma frequiência e que podem diferir em amplitude (RUSSO 1993). Assim, essa composição determina as noções essenciais de sensação do som emitido e captado.

A freqüência está relacionada à tonalidade ou altura da voz, com uma sensação psicoacústica ( $p$ itch) entre agudo e grave e representa o número de ciclos (adução e abdução das pregas vocais) realizadas em um segundo. É medida em Hertze determinada pelas propriedades de massa, rigidez ou tensão (RUSSO 1993; HIRANO e BLESS, 1997) e tamanho (comprimento) da fonte (ABITBOL e col. 1999; BEHLAU 1991). A vibração da prega vocal ocasiona uma freqüência primitiva, de maior amplitude, e o movimento ondulatório da mucosa gera freqüências adicionais, múltiplas da freqüência fundamental, conhecidas como harmônicos que, por efeito de ressonância - compatibilidade da onda às dimensões do tubo laríngeo - ș̃o amplificadas nas cavidades supraglóticas estabelecendo os formantes (PINHO e CAMARGO 2001), que representa a banda de maior energia no espectrograma (PITTAM 1994). 
O conjunto de freqüências, capaz de ser produzido por um indivíduo, do som mais agudo ao mais grave, é denominado extensão vocal (ou tessitura da voz, no canto) de acordo com LE HUCHE e ALLAL (1999) e HIRANO e BLESS (1997), traduzindo a habilidade de alterar a forma e o comprimento das pregas vocais, do controle respiratório, além da competência neuromotora (HIRANO e BLESS 1997).

A amplitude da onda sonora é a quantidade de energia conduzida por segundo sobre o metro quadrado (RUSSO 1993). Está vinculada à intensidade de um som e representa a variação de pressão subglótica, a princípio, e por contrações laringeas e supra-laringeas (LE HUCHE e ALLAL 1999), sendo classificada, auditivamente, por uma escala entre fraco e forte, denominada loudnesss (PINHO e CAMARGO 2001) e é medida em decibels (ABTTBOL 1999).

A qualidade vocal ou timbre está subordinado à relação dos harmônicos e também dos formantes, ou seja, é estabelecido pelas características da fonte sonora (RUSSO 1993). Depende, dessa forma, das "modalidades de aproximação das pregas vocais e das características anatômicas das cavidades de ressonância, [...] assim como do arranjo entre elas" (LE HUCHE e ALLAL 1999, p.153). Porém, PIT AM (1994) insiste que o termo deveria ser utilizado apenas para a produção sonora dos locais laríngeos, e não supralaríngeos, por ser este o diferencial individualizado.

DE acordo com essas informações, se o sistema auditivo apresentar alterações, seja por enfermidades associadas ou por comprometimento local, o feedback sonoro conduzirá aos ajustes necessários à utilização da voz modificando o funcionamento laríngeo, de forma que pode acarretar sobrecarga ou desequilíbrio entre as forças vigentes, propiciando desgastes aliados aos naturalmente ocorridos pela idade (FERREIRA e col. 1992). 
As propriedades acústicas do som glótico (altura, intensidade e qualidade) são resultantes da ação vibratória horizontal e vertical, sendo esta última explicada pelo modelo do vibrador duplo de corpo-cobertura (HIRANO 1974) e aperfeiçoada pela proposta de TITZE (1980) em relação à natureza dos movimentos. KITZING (1985) ainda elucida a teoria salientando a diferença entre as fases da borda superior e inferior na abdução e adução glótică.

Fatores como tônus, alongamento ou tensão, espessura, massa muscular vibrátil, pressão de justaposição, duração da fase de coaptação, dentre outros, segundo LE HUCHE e ALLALI (1999), dependem das condições físicas das pregas vocais, e as alterações, afetarão as características acústicas da voz.

Para SATALOFF (1998a), fundamentado na física e na fonética acústica, com pressupostos do modelo linear de fonte-filtro discutido por FANT em 1970, a voz é resultante da interação entre a energia da fonte, o vibrador e o ressonador, sendo expressa por um espectro harmônico. Inclui basicamente como fatores que influenciam a altura e a intensidade do som, a pressão subglótica, a impedância glotal, a velocidade da glote e a pressão supraglotal. HIRANO e BLESS (1997), sob os mesmos preceitos, discutem a tensão laríngea, a amplitude de vibração, força muscular da laringe e pressão subglótica como elementos de predomínio no estabelecimento da altura e da intensidade sonora.

Além disso, ainda há interferência do sistema endócrino, que, direta ou indiretamente, desde a formação embriológica (MÜLLER 1996, HENICK e SATALOFF 2002), opera mudanças sistêmicas ou laríngeas específicas e localizadas nos revestimentos (como citado anteriormente), articulações, cartilagens e músculos revelando o impacto causado, motivo de pesquisa deste projeto. 
Todos os componentes atuantes e caracteristicas sonoras elencados pelos autores são passiveis das influências exercidas pelos hormônios sexuais.

Para ABITBOL (1999), a qualidade vocal é o elemento diretamente hormônio-dependente, e aquele que caracteriza cada indivíduo, "é o espelho do ciclo hormonal da vida" (ABTTBOL 2001). É a qualidade fônica que dará personalidade, identidade à voz, segundo BLOCH (2000). PITAM (1994) concorda com a caracterização individual, porém, refere que a qualidade vocal encontra-se entre a produção e a percepção da voz, discutindo que a teoria do modelo único (suposta identificação do individuo, aparentemente com o mesmo valor de exclusividade da impressão digital) é contestada enfrentando contraposições relacionadas à sua natureza, pois a voz é passivel de distorções no espectograma, a subjetividade acarreta alterações em certos aspectos do processo, e há sérias implicações sociais nos equivocos de sua análise.

As técnicas e a tecnologia para a visualização das estruturas em movimento, como a eletromiografia, eletroglotografia, a nasolaringo endoscopia, estroboscopia, as medidas aerodinâmicas, o potencial evocado laríngeo, a quimografia, as análises computadorizadas da voz, dentre outras, muito contribuíram para o avanço dos modelos teóricos e, principalmente, para a atuação terapêutica do fonoaudiólogo, ou pedagógica dos professores de canto.

A complexidade e fragilidade brotada até então, manteve-se ainda em uma escala biológica e de funcionalidade das estruturas laríngeas e sistemas de produção vocal, tornando a voz mecânica, inerte, impermeável, higienizada e asséptica, por assim dizer - quase não humana.

Ainda sob esta perspectiva, as repercussões da menopausa, sobre a laringe e a voz das mulheres, são observadas e descritas com maior freqüência. 


\section{3c - "O crepúsculo das divas": a voz das mulheres na pós- menopausa}

A preocupação histórica sobre a influência dos hormônios gonadotróficos na laringe e na voz feminina aparentemente surgiu em 1851, com uma citação de Thilbert no Dicionário de Medicina, conforme assinala PERELLÓ e MIQUEL (1973). Alguns resultados de pesquisas são publicados por autores como AMADO (1953), GREENE e DALTON (1953); HILDERNESSE (1956); TARNEAUD (1961); GALLI e col. (1965); GREENE (1980), e as investigações desenvolveramse, no decorrer das décadas, sobre períodos de gravidez, durante o ciclo menstrual e em algumas disfunções endócrinas. Os estudos foram demonstrando as semelhanças entre os processos da mucosa vaginal e da laringe, que resultava em disfonias pré-menstruais, com queda da freqüência fundamental e rouquidão, provocadas pelo espessamento da mucosa devido à elevação da taxa de estrogênio no sangue, aumentando as células eosófilas e cariopicnóticas; ou edema, congestão e leve paresia das pregas vocais na gravidez.

Somente em 1981, GONZALES apresentou resultados sobre a voz de mulheres cantoras com mais de 40 anos, e o impacto da menopausa e dos contraceptivos orais passaram a ser pesquisados.

JACKSON-MENALDI (1992) envolveu-se com estudos dos impactos da menopausa e dos contraceptivos orais sobre a voz cantada e, principalmente, sobre os tons agudos.

Em 1994, BOONE e MACFARLAINE, acusam a disfunção endócrina como causa de mudanças na frequiência fundamental, tornando a voz extremamente grave ou aguda. A secreção excessiva de androgênios na menopausa passa a ser 
vista como responsável pelo espessamento da borda glótica e do aumento da massa da pregas vocais, capazes de produzir redução na altura e aspereza vocal.

BOULET e ODDENS (1996) aplicaram um questionário na Bélgica, Holanda e Áustria para cantores clássicos (48 mulheres e 24 homens) entre 40 e 74 anos, e reconheceram que, geralmente, ocorrem mudanças na voz por volta dos 50 anos, principalmente para as mulheres. Apesar da população investigada ter conhecimento da importância da voz em suas atividades profissionais, uma grande parte não procurou especialistas, anteriormente à pesquisa, porque não tinha informações a respeito do que poderia ser realizado para retardar ou amenizar os efeitos do tempo sobre o processo vocal.

As mulheres associaram as mudanças na qualidade vocal à menopausa, ao uso do contraceptivo oral ou aos períodos de menstruação. Fases essas referentes às mudanças processuais dos hormônios atuantes.

A comparação entre esfregaços ${ }^{1}$ das pregas vocais e do colo uterino, realizada por ABITBOL e ABTTBOL (1998), com 100 mulheres em menopausa de 48 a 60 anos, apresentaram aspectos citológicos e histológicos surpreendentemente semelhantes.

Neste estudo, $42 \%$ dos profissionais da voz revelaram mudanças laríngeas e vocais nesse período. Somente 17 mulheres queixaram-se de problemas vocais, porém, na exploração dinâmica realizada nas 83 mulheres que não notaram distúrbios, foram encontradas características alteradas.

Algumas poucas pesquisas foram encontradas no Brasil no âmbito do relacionamento entre os componentes voz e hormônios sexuais, por

\footnotetext{
'Esgregaço é "a preparação para estudo microscópico, que se obtém pela distensão, sobre uma lâmina de uma camada delgada de matéria orgânica", segundo o Novo Aurélio, dicionário da língua portuguesa, século XXI.
} 
fonoaudiólogos, e em um mundo onde a comunicação verbal é essencial, a necessidade é premente.

Artigos com estudos quantitativos fonoaudiológicos que incidiram sọbre a repercussão dos hormônios nas pregas vocais e na voz envolviam situações de ciclo menstrual. SILVA e DE BIASE (2000) não obtiveram resultados significativos nos valores das mudanças da freqüência fundamental, em estudos da mulher na sindrome pré-menstrual. MOLINA e col. (2000) demonstraram que há tendência da voz agravar-se no período pré-menstrual, em relação ao trans e pós-menstrual, contudo não encontraram relação significativa entre número de sintomas de tensão pré-menstrual e a redução de frequiência fundamental da voz.

Foram encontrados, ainda, trabalhos de discussão do assunto em iniciação científica e monografias de especialização em Fonoaudiologia, na área de voz. MAGNO (1999), discutindo sobre a voz da mulher na menopausa, aponta as causas hormonais das mudanças vocais, e a eficiência da terapia vocal. VASCONCELOS (2000), com um trabalho de percepção vocal, conclui que a maioria das mulheres não associa mudanças vocais com alterações hormonais. BICALHO e MARQUES (2001) relatam a atuação dos anticoncepcionais sobre a voz, concluindo que o agravo é real, que os profissionais da voz devem ser advertidos e que a terapia fonoaudiológica pode ser prejudicada em função da manutenção do hormônio administrado, desprezando a evidência da disfonia instalada em função do medicamento.

Sobre o envelhecimento, pesquisadores como BEHLAU e PONTES (1995); MAGALHÃES (1996); FEJJó e col. (1998), CASSOL e BEHLAU (2000), estabeleceram alguns marcadores de voz, por meio de análise perceptiva auditiva e 
acústica, que apontam ou especificam a senescência vocal em sujeitos com mais de 60 anos, ultrapassando os efeitos imediatos da menopausa.

Aparentemente, a Fonoaudiologia está iniciando um processo de sondagem mais específica e profunda sobre a relação voz e esteróides, contudo, vários autores da área da saúde incluem explanações minuciosas das condições vocais durante a atuação e privação hormonal.

Para BOULET e ODDENS (1996), durante a menopausa as mulheres apresentaram rouquidão, compressão do registro, menor flexibilidade das pregas vocais e estabilidade vocal reduzida. Todos os cantores participantes da amostra (72) tiveram alguma experiência negativa com mudanças de voz entre 40 e 60 anos. As mulheres relataram problemas relacionados à emissão vocal, controle da voz, efeitos sobre as pregas vocais e manutenção dos registros agudos. Diferente dos homens em que o problema vocal geralmente foi associado ou tinha uma causa identificada como diabetes, alergias, perda de peso. Estes referem rouquidão, voz escura e débil, aumento da fragilidade/sensibilidade vocal e dificuldades na transição de registro.

ABITBOL e ABITBOL (1998) salientaram a atrofia muscular de pregas vocais uni ou bilateral, diminuição da espessura da mucosa, e aumento de massa, com redução da amplitude na fonação e assimetria vibratória, perda da característica da cor nacarada e aparecimento de microvarizes, rebaixamento da vibração intraglótica e da intensidade da voz gritada, da voz projetada e da cantada, compressão do registro, com perda de certas freqüências e qualidade monocórdia.

Nessa pesquisa, mesmo em mulheres sem queixas, foram encontradas diminuição das respostas rápidas nos extremos dos registros, menor agilidade das pregas vocais, alteração na constrição do ligamento vocal, mucosa da prega vocal 
mais delgada, amplitude de vibração débil e reduzida, com zonas de rigidez, mucosa sub-atrófica com células basófilas, e células glandulares diminuidas nas bandas ventriculares, compressão do registro e perda dos formantes nos agudos, perceptível na voz falada cotidiana.

SATALOFF e col. (1997) incluem componentes que geram prejuízos vocais como decréscimo da força pulmonar, atrofia dos músculos laríngeos, enrijecimento das cartilagens da laringe, maior massa das pregas vocais, virilização da voz, mucosa adelgaçada com perda da elasticidade e das fibras de colágeno. Isso corresponderia à capacidade respiratória reduzida, decréscimo em toda a extensão vocal, principalmente nos agudos, mudanças nas características de vibração, desenvolvimento do tremor, decréscimo do controle respiratório e imprecisão do pitch (tonalidade).

Afirmam, ainda, que o problema se agrava quando doenças sistêmicas como o diabete, hipertensão, disfunções tireoidianas, ou enfermidades específicas como afecções do sistema respiratório, alterações auditivas, distúrbios gastroesofágicos bastantes comuns, instalam-se nesse periodo (SATALOFF e col. 1998).

Atualmente, tem-se claro como a laringe é particularmente atingida pelos processos sistêmicos e pode estar refletindo o estado de saúde geral por meio de sua mobilidade, coloração, condições de vascularização e de hidratação.

Quando cessa a função dos esteróides, a ausência dos hormônios interfere generalizadamente na hidratação da mucosa, reduzindo a secreção da glândula epitelial e da lubrificação que otimiza a atividade e a elasticidade da laringe, propiciando a introdução de agentes prejudiciais à saúde, acordado em SATALOFF e col. (1998). 
Ao mesmo tempo e em conformidade às circunstâncias de redução dos hormônios ovarianos, a testosterona e seus derivados, produzidos pelas células theca e pelo córtex da supra-renal, continuam sendo secretados sem depararem-se com seus antagônicos, agindo diretamente sobre os tecidos da laringe.

A secreção do cortisol pelas adrenais varia durante o dia em função do controle hipotalâmico, interferindo com o metabolismo de vários sistemas corporais, incluindo a ação da água sobre os eletrólitos (GUYTON e HALL 1998; DÂNGELO e FATTINI 1998).

A associação desses fatores conduz a uma tendência da camada superficial da lâmina própria das pregas vocais, ao redor dos 40 anos, ir tornandose mais espessa e edemaciada, e aos 50 anos, a camada intermediária inicia um processo de atrofia das fibras elásticas encurtando a porção membranosa. $\mathrm{Na}$ camada profunda há o adensamento das fibras de colágeno, espessando as pregas vocais, enquanto o músculo vocal, por ser estriado, está propenso ao atrofiamento (HIRANO 1974; LINVILLE 1996; SATALOFF e col. 1998).

A mudança de epitélio que, de maneira discreta, apresenta-se citologicamente sub-atrófica, isto é, quase sem queratinização, e com células basais externas, esféricas, cujo citoplasma é basófilo e o núcleo tem a cromatina dispersa, conduz a uma redução da amplitude e da rapidez dos movimentos das pregas vocais e dos ajustes laringeos.

Em 2003, ABITBOL e col., médicos, investigam a respeito da síndrome pré-menstrual e as complicações nas fonocirurgias. Os fonoaudiólogos GASPARINA e BEHLAU descrevem as características da voz senil nos filmes americanos e FIGUEIREDO avalia a voz de 30 mulheres por meio de análise acústica (variação da intensidade, freqüência do som e número de vibrações por segundo) durante o 
período pré-menstrual, concluindo que há alterações vocais que prejudicam aos profissionais da voz. ROTHMAN e col. apontam as características vocais percebidas em falantes adultos jovens e idosos, aparentemente objetivando compreender o processo natural de cada fase da vida.

Para BEHLAU e PONTES (1995), "as alterações estruturais produzem alterações funcionais" e, assim, com toda a dinâmica vibratória prejudicada, a fonação transparece as características subseqüentes ao processo normal de modificação ou de envelhecimento da laringe.

A redução da extensão vocal deve-se à menor variação do comprimento, da elasticidade e da plasticidade dos ligamentos e músculos intrinsecos e extrínsecos da laringe (BEHLAU e col. 1988).

O espessamento, o enrijecimento das pregas vocais e o deslocamento para baixo da laringe com o avanço da idade ocasionam o agravamento da voz, com a diminuição da freqüência fundamental (BEHLAU e col. 1988; SATALOFF 1997).

Nos idosos, os sinais mais presentes envolvem a atrofia dos músculos intrínsecos, desidratação e diminuição da mucosa, perda da elasticidade dos ligamentos, calcificação das cartilagens, arqueamento e flacidez das pregas vocais (MUELLER 1982; BEHLAU e PONTES 1995; FEIJÓ e col. 1998; BLOCH 2000).

É possivel que variáveis, como extensão e sincronismo respiratório, possam estar refletindo estados de transição e tensão individual, que interferem na projeção da voz (BLOCH 2000). Também é provável que a ocorrência maior das intensidades máxima e mínima encontradas nas freqüências mais graves, indique maior controle e conforto vocal, em idosos (MAGALHÃES 1996), ou de acomodação entre os fatores biológicos e fisiológicos, de acordo com PITTAM (1994). 
Sem dúvidas, no processo de adaptação da ausência do estrogênio e do progesterona, consequiências sobre a produção sonora são observadas e vão acentuando-se com o decorrer dos anos. Contudo, a intensidade vocal sofre também o impacto do processo geral de decadência do tônus muscular e da dinâmica respiratória.

Conforme SATALOFF e col. (1997), a idade está associada com a deterioração de todas as funções corporais: as estruturas mudam, e não apenas o seu desempenho. As teorias explicam o fato focando em processos celulares individuais, transmissão genética, entre outras. Mas todas elas indicam como o envelhecimento é percebido no corpo. Os tecidos e o sistema nervoso se atrofiam, e a química responsável pela transmissão nervosa é alterada. Os ligamentos se debilitam, as cartilagens se ossificam, as articulações desenvolvem irregularidades que interferem no movimento fluente. A precisão, a velocidade, a resistência, a estabilidade, força, coordenação, capacidade respiratória, rapidez na condução nervosa, potência cardíaca e função renal demonstram o envelhecimento.

As pregas vocais também se deterioram, perdendo fibras colágenas e elásticas, responsáveis pela resistência, diminuindo a suavidade, estabelecendo as mudanças vocais que surgem com a idade. Em cantores notam-se mais tipicamente as mudanças de perda da extensão vocal, alteração das características do vibrato, desenvolvimento do tremor, perda do controle respiratório, fadiga vocal, pitch impreciso, e outros aspectos indesejáveis.

Não obstante, esse declínio ocorre gradual e progressivamente encetando um novo desafio.

Portanto, se pensarmos apenas pela vertente da fisiologia, a voz da mulher após a menopausa apresentará os primeiros sintomas e sinais, nem sempre 
perceptiveis auditivamente na fala cotidiana, seguindo um processo natural, que irá tornando-se mais intenso quanto mais idade atingir.

Porém, a manutenção da integridade sistêmica e das estruturas locais, mediante um modo de vida saudável, em toda a sua amplitude de sentido, pressupõe um retardamento na degeneração, expressando uma juventude prolongada, traduzida, inclusive, nas características vocais.

Assim é possível que, mesmo após a menopausa, a voz mantenha-se sem denunciar as condições estruturais por tempo mais ou menos indeterminado. Ou o seu inverso, delatar a ausência de saúde, mesmo durante a juventude cronológica.

O tema tem suscitado a atenção dos estudiosos, especialmente dos médicos, em todo o mundo, e assim, vemos novas investigações ocorrendo em Israel (AMIR e col. 2002), na Rússia (CHERNOBELSKY 2002) e na Suécia (SAMSIOE 2002). Discutem os efeitos dos contraceptivos orais, (em que os resultados sugerem melhora da voz na sua administração), das técnicas de canto durante o ciclo menstrual (decrescendo as mudanças laríngeas na sua utilização), da terapia de reposição hormonal com androgênio (em que há o agravamento da voz), respectivamente. A respeito da reposição hormonal, os estudos de ALLYN e BRIZEL (2002) concluem que a administração balanceada de estradiol/progesterona tornam as alterações vocais menos intensas.

Contudo, após as investigações de BERAL e col. (2003), em que se reconhece o risco aumentado da incidência e da mortalidade de câncer de mama e colon-retal, e o acréscimo do risco para tromboembolismo, na população usuária da Terapia de Reposição Hormonal (TRH), os pressupostos, conceitos e aplicação aludidos exigem uma revisão criteriosa. Em especial, se considerarmos os 
contundentes comentários de LAGRO-JANSSEN e col. (2003) que desencorajaram a sua administração, e propuseram a discussão de outras alternativas solucionadoras. Admitiram a utilização da TRH como mais uma lição histórica para extremas precauções no exercício da Medicina, alegando que "a falta de evidências de riscos (ou benefícios) é diferente das evidências de não-riscos (ou beneficios)". Reconheceram que a regra de evidência fundamentada na medicina foi quase completamente despercebida durante a promoção da TRH, e que portanto, o evento deverá servir de advertência para que possam melhor proteger e promover a saúde da população.

Finalmente, tendo em vista os conhecimentos abordados, passaram a ser desenvolvidos os pressupostos desta investigação.

\section{Delineamento dos pressupostos teóricos}

Existindo a possibilidade de rompimento com a concepção hegemônica que estabelece um vínculo causal entre a condição orgânica e os reflexos nos resultados da fisiologia, deve haver, no conjunto, a implicância de fatores não salientados nesta vertente de estudos.

Assim, embora os argumentos organicistas sejam convenientes, não são de todo convincentes, e a natureza humana implícita, tanto na menopausa quanto na voz exige, metodologicamente, uma investigação mais totalizante que articule os hiatos multivariados e a diversidade das faces existentes internamente entre cada uma e, de forma mais ampla, entre ambas. 


\section{4a. - "As coisas que são vistas são transitórias, mas as coisas que não são vistas são eternas"- a mirada social sobre a menopausa}

Quando se elege um periodo distinto como cenário para estudo, correse o risco de reducionismo, aplicando um ponto de vista mecanicista e um método analítico cartesiano de raciocínio que, utilizado com excessiva ênfase, "levou à fragmentação do pensamento em geral" (CAPRA 1982, p.55) conduzindo a uma atitude generalizadora na ciência, transformando os fenômenos complexos em partes constituintes a serem compreendidas.

No entanto, para BAUER (1997) é possivel, quando se realiza essa predileção, reconhecer o agente que construiu sua história; tomar o tempo como razão de ligação e também de ruptura entre esse sujeito e o objeto; utilizar o valor simbólico do tempo, implantado no íntimo dos indivíduos. As datas (e por extensão, os períodos e fases), portanto, dariam relevância aos pontos de luz nas ocorrências dos séculos e desvendariam os ápices dos icebergs, marcos naturais que assinalam as grandes massas submersas, pois

Entender uma época é estabelecer uma leitura da relação do homem com a realidade, produto de estar com ela e de estar nela, pelos gestos de criação, recriação e decisão, é participar de um processo dinamizador do mundo [...] Uma época permite-nos identificar, de forma panorâmica, o trabalho criador do homem, temporalizando os espaços geográficos que o cercam e produzindo cultura (p.48).

É nesse sentido amplo historicamente e abrangente no que diz respeito ao ser humano que se investigou a mulher no Climatério, após a menopausa, 
diferenciando-a da perspectiva biologizante adotada por grande maioria dos estudiosos.

Embora NOTELOVITZ (1984) tenha apontado uma medicina do climatério com exigências sociais, sua relevante tentativa de 'somar visões', salientando conhecimentos profissionais das áreas biológica, psicológica, sociológica e antropológica, aparentemente manifestou-se ineficiente para provocar mudanças no paradigma objetificante.

É provável que a complexidade que esse cenário circunscreve, obstaculize a visão de um sujeito completo, dificultando a posição mais abrangente dos profissionais de saúde, conduzindo-os a pontos de partida centrados nos padrões estereotipados simplistas e fragmentados, como apontam HEGG e col. (1994).

Contrapondo-se ao estabelecimento dessa visão reduzida, HALBE (1995) critica o valor atribuido pelo modelo médico aos sintomas biológicos, enfatizando o poder das características psicossociais.

Atribui relevância aos pontos críticos do climatério: as ondas de calor, as mudanças corpóreas importantes, a sexualidade e erotismo, a perspectiva do marido diante dos problemas enfrentados pela mulher (inclusive quanto ao uso do Viagra). Acusa, como agravante, a intensidade dos sintomas, a caracterização intrapsíquica, a qualidade de vida pessoal e familiar, os fatores socioculturais.

O vigor desses fatores desponta na maneira evidente de algumas mulheres enfrentarem todas as questões cotidianas, e também, as mudanças mais significativas, ou no seu inverso, em como se deixam envolver entrando em conflitos perenes. 
Em momentos de alteração hormonal, como gravidez, menopausa, adolescência, entre outras, embora também, em ocasiões mais estanques ou prolongadas de ansiedade, tensão ou angústia, ou sempre que seja exigido um posicionamento ou transformação na sua visão de mundo, observa-se a instauração de uma crise. Crise compreendida aqui como em algumas filosofias orientais, significando revolução, passagem para um outro tipo de vida.

Assim, para HALBE (2000a), a crise da meia-idade é resultante da constatação do envelhecimento e da finalização da vida - a menopausa é apenas um mote para questionamentos, um marco concreto para introspecção. Dessa forma, com a realidade impondo os limites, quase obrigatoriamente ocorrem mudanças psicológicas significativas que alteram a identidade, induzindo a novos ajustes.

Concordando, de maneira plena, com HABERMAS (1993, p.100), que define emancipação como "transformações descontínuas na auto-compreensão prática das pessoas", ordenando, também de forma não-linear, as (re)construções da identidade.

Os estereótipos da mulher nessa fase da vida são incorporados por diferentes processos educativos, porém, calca-se no "valor do útil, do produtivo, e aliam-se a uma visão patriarcal da posição da mulher na sociedade", consoante HARDY e col. (1995, p.35), induzindo às noções de declínio e marginalidade. Semelhante às rotulagens de qualquer natureza ou domínio, tanto homens como mulheres são de tal forma envolvidos que tudo passa a ser naturalizado.

Para COSTA (1995, p.23), "a mulher que sobrevive aos seus ovários parece ainda não ter direito de sobreviver decentemente a certas limitações 
impostas pela idade [...] uma vez que o consumismo é a tônica e o valor maior é a produção".

SEVERINO (1995, p.15), em concordância, delata que "o corpo humano, concretamente e na forma como é percebido pelas mulheres, acompanha a gradação de valores gestados pelo sistema dominante", que, não se negando estar a opressão feminina ocorrendo sob mãos masculinas, considera-se que tanto um quanto o outro sofrem os efeitos das forças coercitivas dos modelos sociais e o peso da sua violência na expropriação da vontade.

Referindo-se às mesmas condições de lugar social concedido à mulher, HALBE (2000a) salienta como o simbolismo cultural que envolve a menarca, a menstruação e a menopausa, e os valores imputados a esses eventos, contribuem para o modo de se trabalhar com essas questões.

Os papéis assumidos pela pressão social são "reguladores das ações [...] e trazem em seu bojo as emoções e atitudes a elas relacionadas" (HARDY e col. 1995, p.31). Dessa forma, não se admira que a menarca seja comemorada e a menopausa temida: o cerne do papel assumido pela mulher vista como reprodutora da espécie, sustentado socialmente, é o de mãe, isto é, daquela que cuida.

Muitos estudos antropológicos em diversos países não ocidentais, relatam a assintomatologia e a falta de potencialidade de crise da menopausa explicada pela simples aquisição de um estado social diferente, com ganhos para todos os implicados (mulher, marido, família, grupo social de inclusão).

Favorecendo essa posição mais totalizante, surge por exemplo, na realidade da maioria das práticas de Medicina alternativa, provenientes de concepções orientais, a ênfase no doente, e a convicção de que a doença é principalmente um desequilíbrio interno, adotando-se "uma postura holística e 
naturalística diante da saúde e da doença", conforme define QUEIROZ (2000, p.364).

Caminhando pelo terreno da Homeopatia, que parte de conceitos globais da Medicina Holistica, segundo MORAES (2003), o que ocorre em primeiro lugar é o desequilíbrio do ser integral, que vai perdendo a sintonia com a vida, desarmonizando o funcionamento dos órgãos do corpo, debilitando a saúde, iniciando a enfermidade, manifestada em cada um de uma maneira peculiar. 0 papel do médico é de localizar o fator desencadeante do estado atual do ser que está enfermo, da gravidade deste estado, identificando o desequilibrio. Dessa forma, o indivíduo é tratado considerando suas características físicas e emocionais, e como cada um demonstra sua doença mediante uma maneira particular e única do seu sofrer, assim a seleção de medicamentos será diferente para cada uma das pessoas.

O tratamento pelo princípio da Homeopatia, de acordo com MELLO (2003), implica no uso de substâncias em doses mínimas oriundas de vegetais, minerais ou animais. Seus principios foram expostos por Samuel Hahnemann no final do século XVIII, e está baseada na cura pelo semelhante (Similia Similibus Curentur). Isto quer dizer que, se uma substância é capaz de produzir determinada alteração (sintoma) em um indivíduo são, teria a capacidade de curar esta alteração, em uma condição de doença, quando dada em doses pequenas, sob determinadas condições de diluição.

Para a Homeopatia, a menopausa é uma fase natural na vida das mulheres, assim quem deve ser tratada é a mulher, não a menopausa. Cada uma viverá sua própria menopausa, da sua maneira particular, com seus sintomas individuais (MORAES 2003). 
Em investigações centradas nas concepções da Medicina Tradicional Chinesa, datada de mais de 5000 anos, de acordo com NGHI (1996), desde há muito, é conhecida a relação entre a laringe e os órgãos sexuais femininos.

Dentre os canais de energia, há os denominados "curiosos" (com sentido de isolado, singular) que possuem a função de estabelecer relação e harmonia no campo que compreende os trajetos dos canais de energia principais. Os canais de energia curiosos são peculiares, originam-se todos nos rins, não obedecendo regras de alternância do Yang e do Yin. Contrariamente aos outros canais, formam sistemas de conexão chamados "anfitrião-hóspede" (associação Yin-Yin e Yang-Yang), circulam de baixo para cima, não penetram nos órgãos e conduzem a quintessência energética para a região cefálica. Os distúrbios de um desses canais, designado Chong-Mai, considerado Yin, são provocados por agentes etiopatogênicos energéticos e manifestam-se por sinais e sintomas, que são queixas nas mulheres, surgidas geralmente em situações de mudanças hormonais ou doenças genito-urinárias. Entre eles estão a lombalgia, sensação de subida de energia da região pélvica, dor e plenitude abdominal, vômitos, prurido vaginal, dor e inchaço vaginais, hemorragia uterina, endometriose, prolapso uterino, espasmo vaginal, dismenorréia, leucorréia, esterilidade. Quando o acometimento é do canal toracofacial, uma de suas subdivisões, manifesta-se por precordalgia, dispnéia com sensação de subida de energia, amigdalite e afonia ou disfonia, com sensação de contração da faringe, secura da boca e do nariz.

Segundo IÓRIO (2001), a Medicina Tradicional Chinesa "identifica o fator emocional como fundamental na fisiologia das afecções da mulher" (p.12). Os transtornos psíquicos desequilibram Yin/Yang, afetando o "fígado [...] essencial no desenvolvimento harmonioso das funções biológicas, emocionais, sexuais e 
reprodutivas" (p.12). A sua alteração transtorna o eixo hipotálamo-hipofisário e sistema límbico, perturbando a organização do processo hormonal.

Diferentemente da perspectiva do oriente, a tradição ocidental desconsiderou quase completamente as determinantes culturais, ignorando que a relação do corpo humano realiza-se somente quando está espacialmente referida numa relação social. Mais do que isso, arenas escassas foram e são abertas para que a mulher levasse em consideração o saber que ela própria tem de si (SEVERINO 1995).

Como apresentar uma relação dialética de alteridade, se além de não se externar sobre o tema, ainda encontra poucas situações de se contrapor ao equivalente (será que é?) do climatério masculino, por exemplo? Assim, a andropausa deverá ser debatida por homens (de quem é de direito) e por mulheres, que também sofrem a suas conseqüências, para ser validada.

Dessa forma, as relações que se constroem por meio da poderosa força social, estão permeadas por situações e circunstâncias comunicacionais que, consoante JODELET (2001), propiciam a abordagem do fenômeno cognitivo, desempenhando um papel fundamental nas interações e contribuindo para a criação de um universo consensual.

\section{4b. "E no princípio fez-se o Verbo": a função de comunicação da voz}

Entendendo processo comunicacional como ação comunicativa de acordo com HABERMAS (1993), salienta-se a voz humana não somente como resultante da dinâmica entre as partes que constituem o trato vocal, mas efetivamente adotada na interação entre o indivíduo e o mundo. A implicação vai 
muito além da tradição do contexto comunicacional de emissor-receptor, abrangendo a relação desenvolvida que

realiza-se normalmente numa linguagem comum e num mundo explorado pela linguagem, pré-interpretado, em formas de vida compartilhadas culturalmente, em contextos normativos, em tradições, rotinas [...] mundos da vida que são porosos uns em relação aos outros, que se interpenetram e se interligam (p. 106).

A fonação compreende, portanto, um elemento da linguagem cotidiana, que conduz obrigatoriamente ao ato de comunicação. Assim, assumida em uma "perspectiva ampla, relacionada às necessidades do trabalho [...], às expectativas do sujeito sobre a vida, às funcionalidades da voz em sua realidade e contextos cotidianos, às possibilidades de expressão do sujeito e às vinculações com a sua auto-imagem e auto-estima", conforme PENTEADO (2003, p. 65).

Para uma grande maioria dos autores (FERREIRA 1977, 1985, 1988, 1991, 1995, 1998, 2000; BRANDI 1984; PITTAM 1994; BEHLAU E PONTES 1995; COLTON E CASPER 1996; HIRANO e BLESS 1997; LE HUCHE e ALLALI 1999; BLOCH 2000; CHUN 2000; RAMECK 2001, para citar alguns dentre muitos) a voz é apontada também como expressão maior de emoções, como identidade pessoal e como uma das maneiras de comunicação interpessoal, de relacionamento com o outro.

Para VYGOTSKY (1987), a fala originou-se das mesmas respostas vocais expressivas de estados afetivos observados em muitos animais, contudo, reações com função social à voz humana são notadas desde o segundo mês de vida. Pensando o desenvolvimento ontogenético como a atualização da filogenia, o autor deduz que os primeiros sons produzidos pelos hominideos e seus descendentes 
vinham fundamentalmente submeter-se à função social de relacionamento e comunicação.

WASZ-HOCKERT ${ }^{11}$ e col., apud BEHLAU (1991), apontam os sinais característicos dos estados emocionais do recém-nascido até cerca de sete meses, que exigem interpretação da mãe. Manifestações estas que dependem, então, da aprendizagem de ambos na constituição de um relacionamento, envolto pela linguagem e, no momento, traduzido muito mais por recursos prosódicos que, ao longo da vida irão refletir sempre os estados internos e de intenção do discurso, apesar de manterem-se como cenário ou segundo plano para um código lingüístico.

Evidenciando esses preceitos, BEHLAU e PONTES (1995) afirmam que a qualidade vocal sofrerá influência das condições fisicas e psicológicas do indivíduo, porém, inserido em um contexto de fala (dimensão sócio-cultural).

MOSES, em 1954, categorizou e conceituou os parâmetros sócioculturais mais perceptivos para análise cotidiana da voz, como características utilizadas não-intencional ou intencionalmente, assumidas durante a convivência social e afetiva, que identificam o individuo em um determinado grupo, expressando, portanto, as relações consigo e com a comunidade da qual é integrante.

Denominou os conceitos como pathos (ímpetos autênticos de apelo e rejeição); maneirismo (exacerbação intencional de qualificadores do pathos), melisma (apelo deliberado, natural e legitimo, sem os exageros do maneirismo), precisão (vinculada à força, exatidão e coordenação articulatória) e pausa entre as palavras (estabelecida principalmente pela velocidade de fala).

\footnotetext{
1 Wasz-Hockert $O$, Lind J, Vuorenkoski $V$, Partanen $T$, Valanne $E$ The infant cry: a spectographic and auditory analysis. Clinic in developmental medicine, 29, London, England: Heinemann
} 
Quando há ênfase em um ou em vários determinantes da voz, esta poderá manter a função estabelecida de apelo em momentos específicos e de entendimento social, refletindo o enredamento dos envolvidos nas tramas da linguagem dessa coletividade em que se encontram, apesar de essa "nunca ser um meio de reflexão transparente", de acordo com INGRAM (1994, p.146). Para ultrapassar a ausência de transparência da linguagem é que HABERMAS (1989, p.384) elucida: "A razão comunicativa se faz valer pela força do vínculo que possuem $o$ entendimento intersubjetivo e o reconhecimento reciproco; circunscreve, por sua vez, o universo de uma forma de vida comum" (tradução da pesquisadora).

Segundo PITAM (1994), o interesse e estudo sobre a voz, particularmente para a educação, teatro e a retórica, remonta à antiga Grécia e ao Império Romano. Nas artes, as técnicas estabelecidas para expressar as qualidades fisicas e fisionômicas empregavam a característica da voz grave e tensa para indicar bravura varonil, enquanto que a voz não-tensa e aguda representava a covardia. Tanto Cicero, quanto Quintiliano, na Roma antiga, comentam o fato de a voz ter a função de marcar a identidade cultural ou nacional, evidenciando como os ouvintes distinguem com acurácia muitas e especificas emoções na voz, principalmente, as básicas como a raiva, tristeza e alegria.

Atualmente, a análise acústica esclarece que a raiva é caracterizada mais pela freqüência, com o aumento da média e instabilidade da freqüência fundamental, elevação da energia, intensidade média e ritmo articulatório aumentado. Na tristeza há o decréscimo da média de freqüência fundamental, da energia, da intensidade e do ritmo articulatório. A alegria torna-se evidente com o aumento e variação na média da freqüência fundamental, variabilidade das médias 
de intensidade, maior uso de freqüências altas e ritmo articulatório acelerado (PITTAM 1994).

Sob essa visão, a distintividade da voz crepitante e tensa relaciona-se, para os homens, ao alto status, enquanto que para as mulheres, alta solidariedade, principalmente se apresentar soprosidade conjuntamente. A voz hiponasal indicará um status inferior, mas revelará grande solidariedade. A velocidade rápida revela pessoas dominantes, com maior nível de extroversão, dinamismo, competência e credibilidade, em especial, para confidências. Uma velocidade lentificada indica uma menor conotação de honestidade e fidedignidade.

As representações emergidas por MOSES (1954) trazem a oralidade da voz como expressão de ódio e a nasalidade contida na voz amorosa; o desgosto, repressão, ou agressão manifestados pelo golpe de glote. A voz que ele atribui a assim denominada "personalidade normal", em uma fala particular, usa pausas entre as sentenças, examinando e coordenando depois com o que virá em continuidade. Em contraposição, a expressão vocal da "personalidade neurótica ansiosa" sofre a falta de sincronização da pressão laríngea e do diafragma, resultando em tremor, rouquidão áspera, com a inspiração ruidosa. Os fenômenos determinados indicam que a voz é muito mais que uma mera conseqüência do estado orgânico e funcional da laringe, e essa, uma área em que a emoção e a personalidade se entrelaçam.

A externalização de estados psicológicos e de características culturalmente determinadas induzem o ouvinte a inferir os estados afetivos ou emocionais no sinal acústico. Por isso, de acordo com PITTAM (1994),

a voz é um dos recursos de interação social: por meio dela o ouvinte pode inferir traços do falante, tais como personalidade, 
classe social ou condição emocional. A maneira de uma pessoa se expressar pode levar a diversos julgamentos por parte do ouvinte, fazendo com que este atribua ao falante caracteristicas que, muitas vezes, ele nem gostaria de possuir (p. 60).

PITAM (1994) pesquisa a voz falada em interação social, descrita sob a proposta fonética de análise acústica. Adota um modelo de comunicação centrado em uma análise representacional em que o pressuposto, segundo MINAYO (1994, p. 205), "é de que a linguagem representa e reflete quem a utiliza, [...] e o conceito básico é a atitude". Atitude é compreendida como reação, "em forma de opinião ou de ato em presença do objeto", produzindo e traduzindo "um conjunto de juizos de valor", com o objetivo de se ater às unidades de significação "em termos de direção e intensidade dos juízos". Os conceitos de percepção irão fornecer a base para a interpretação das categorias e a relação necessária entre as medidas perceptuais e os correlatos fisiológicos.

Apesar de fundamentar-se em uma teoria caudatária das metodologias positivistas, inerentes à descrição que assume, busca respaldo na teoria de identidade social de TAJFEL (1981) para explicar os valores associados aos componentes que formam a identidade social e a habilidade de comunicação. Acordado aos preceitos desse autor, a identidade pessoal e grupal não se mostram por contigüidade, mas são independentes e interagentes e assim, a comunicação intergrupo e interpessoal.

A comunicação é um complexo multifuncional, de acordo com PITAM (1994), em que aspectos como identidade de grupo, identidade pessoal, emoção, atitude, interagem por vias confusas, dificultando o isolamento de cada um. Assim, 
[...] a voz pode ter muitas funções e um grande número de caminhos para associar os papéis que nós empreendemos, as nossas metas, as atitudes com outras pessoas, os sentimentos ou emoções sobre diferentes aspectos da interação, a nossa identidade e a fática relação entre falante, ouvinte e todos os aspectos envolvidos no gerenciamento e monitoramento da comunicação (p.158).

Assim também, BEHLAU e ZIEMER (1995) revelam que a altura vocal está relacionada com a intenção do discurso, portanto, voltada para o outro, e geralmente indica as características particulares do falante. Apontam o clima alegre e festivo, marcado por maior velocidade ou, ao inverso, o clima triste e melancólico. A freqüência fundamental grave pode refletir energia, proteção ou autoritarismo; mais aguda, dependência, insegurança, imaturidade. Reflete também a relação de gênero, com passagens consideradas vexatórias, desastrosas ou no mínimo cômicas pelos protagonistas.

A extensão vocal refere-se às escolhas de uma sociedade na utilização de maior ou menor gama de sons na fala e no canto, e é muito representativa na decisão das características psicológicas dos papéis de uma ópera por ressaltarem o caráter e o controle emocional do indivíduo.

Os registros vocais, apesar de ser um termo controvertido na literatura, traduzem o contexto entoacional do discurso lingüístico, refletindo uma condição de hạrmonia psicológica.

Na utilização da intensidade vocal é apontada a dimensão do outro e o espaço de cada um, sendo bastante relacionada ao modelo familiar e valores culturais. 
A ressonância indica uma relação com as características emocionais do discurso e do falante, que sugerem narcisismo e sensualidade, sentimentos de raiva e agressividade, preocupação, tensão ou facilidade de expressar emoções, podendo ser influenciada pelo clima regional.

Na articulação, o ritmo e a velocidade permitem assinalar algumas características psicológicas, como depressão, ansiedade, tensão, egocentrismo, raiva, fluência de pensamento, clareza de idéias, mas também relacionar-se aos grupos etários e profissionais, dentre outros. A acurácia da fala e a precisão articulatória conferem credibilidade e organização mental, sendo atualmente consideradas como importantes índices do desejo comunicativo.

LE HUCHE e ALLALI (1999) assinalam que a altura tonal, para além do falante, varia conforme o tipo de emissão e situação: é tão mais aguda quanto se projeta para ser ouvida por todos; é modulada e mais aguda em tom alegre; quase monocórdia na tristeza ou em contextos autoritários.

BLOCH (2000, p.237), tratando das alterações vocais, afirma que "o homem escolhe sua disfonia, cultiva-a com a sua vida, e com a vida de seu ambiente e do mundo em que vivemos". Para ele, a voz identifica, individualiza "porque a laringe registra tudo" (p.250), e tem a capacidade de exprimir "o que somos, fomos e, até, o que seremos" (p.244).

Aponta que sentimentos e sensações podem ser revelados por características da voz empregadas habitualmente nos discursos cotidianos. Assim, em situação difícil, a voz denuncia emoção correndo para o agudo, ou racionalidade descendo para o grave; felicidade agudiza a voz, e a depressão a agrava; a tristeza diminui a intensidade e o timbre empobrece, enquanto que a alegria gera ricos hạrmônicos. 
No que concerne aos estudos da língua oral, sob os vários enfoques, como Análise do Discurso, Sociolingüística, Estilistica, Análise da Conversação, Gramática e outros, a voz destaca-se como fator importante de auxílio à construção e compreensão dos sentidos e significados veiculados, por conseguinte, elemento de distintividade no ato comunicativo.

A propósito, PRETI (1999) elucida que a compreensão da linguagem se faz a partir dos frames, indices que, além do vocabulário e da sintaxe gramatical, abrangem altura, tom e inflexões de voz, mudança de ritmo, entonação e expressões faciais, que denunciam estados de agressividade, humor, malíciā, crítica, avaliação, formalidade ou informalidade, que conduzem o ouvinte ao entendimento do discurso oral. Dessa forma, esses indicativos encerram vinculações sócio-culturais, que o desconhecimento ou inobservância, poderá levar ao fracasso a interação naquele contexto comunicativo.

BARROS (1999) assinala que, na construção dos argumentos ou da persuasão-argumentativa e dos papéis sociais e pessoais em uma conversação, incluem-se processos de reformulação e recursos lingüístico-discursivos como a pausa, o prolongamento da vogal, a interrupção lexical, a repetição - elementos prosódicos - que sinalizam a continuidade do discurso, assumindo "os papéis e a função que Ihes cabem na construção dos sentidos da conversação" (p.68).

A Estilistica apresenta a expressividade, uma importante qualidade da linguagem, principalmente oral, como a capacidade dos falantes de manifestar suas emoções, despertando nos interlocutores sentimentos semelhantes, em um intercâmbio de mensagens comunicativas.

A motivação da expressividade, conforme URBANO (1999), está centrada nas características psicológicas e sociais da linguagem falada, 
distinguindo, pois, traços e efeitos vinculados à expressão dos elementos subjetivos e afetivos, e à expressão dos aspectos interacionais. São efeitos que com o "tempo e o uso perdem sua energia [...] e são substituidos, revitalizados ou recuperados de alguma forma" (p. 122), por conseguinte, não garantem indefinidamente seu valor expressivo e seu sentido no discurso.

Classifica, ainda esse autor, a potencialidade expressiva da linguagem oral de acordo com sua natureza lingüística - os elementos verbais ou segmentais e os elementos prosódicos supra-segmentais e co-segmentais; ou não-lingüística - os elementos cinésicos ou situacionais. Dentre os lingüísticos enfatiza a inerência dos elementos prosódicos à expressão oral, e exemplifica, citando "o tom, o acento, a entonação, a duração, a silabação, as inflexões de voz, os alongamentos, o ritmo, a fluência" (p. 123) e inclui nos co-segmentais "a pausa, a ordem, os deslocamentos" (idem), destacando peremptoriamente a importância da entonação.

Em MARCUSCHI (1999), um dos expedientes para marcar a atenção, sinal evidenciado para contextualização, é a prosódia, composta de "entonação, mudança de altura do som, intensidade, alongamento das vogais, pausa e velocidade, ritmo e mudanças de registro no som" (p.35). Aponta a entonação como um recurso na construção de interesses comuns entre os falantes ou de sugestão na manutenção do discurso e salienta as pausas enfáticas como um ref́orçador ou marca de atenção ao pensamento expresso.

Para RAMECK (2001) as diferenças segmentais na fala são motivadas por características sociais e não tanto por propriedades funcionais, quando considerado o sexo. Entretanto, as diferenças não-segmentais são fontes que revelam informações sobre atitudes e emoções do falante em um ato comunicativo. 
Assim, cantores eruditos e populares, atores, até mesmo poetas, compositores e escritores são especialistas em envolver 0 indivíduo ou a coletividade por intermédio de uma correspondência complexa e multivariada de sentimentos e sensações tendo como base material a sonoridade (SCHURMANN 1989), que reforça as aproximações de certas retóricas grupal ou individual, incluindo a escrita, pois " há sempre soando ao fundo uma contínua presença de ritmo" (MANOEL 1985).

A acentuação ou ênfase nas frases, palavras ou sílabas e também as pausas "fazem aflorar as imagens do texto", conforme GAYOTTO (2000, p.143). Sentindo-se "a dança das palavras, a sua coreografia" (p. 144), o intérprete de um texto revela seu discurso.

Também para locutores, operadores de telemarketing, políticos e outros grupos ocupacionais em que a voz é de essencial utilidade, o conceito de sonoridade torna-se presença marcante na utilização da eloqüência, arte de persuadir, convencer, deleitar ou comover pela palavra (HABERMAS 1987), induzindo à sua verdade ou, ao menos, validade.

Para PITTAM (1994), Aristóteles na antiga Grécia, referia as características de volume, ritmo e harmonia na prática da persuasão, e a combinação entre as variantes grave, agudo e intermediárias para expressar diferentes emoções na retórica. Enquanto o orador Cícero, no Império Romano, enfatizava que as emoções fortes são associadas a um particular tom de voz.

Adotando a relação interativo-social na dinâmica da voz, sob uma perspectiva de gênero, na investigação de RAMECK (2001) com mulheres que assumem papéis de liderança e poder em grandes empresas brasileiras, as entrevistadas, entre 39 e 52 anos, apresentaram, dentre outras marcas, o 
agravamento da tonalidade vocal. Embora a pesquisadora caracterize como a acomodação, consciente ou inconsciente, ao padrão masculino para obtenção de aprovação social, respaldada teoricamente nas concepções praticadas, desconsidera qualquer vinculação com o período do climatério, capaz de proporcionar as condições para a concretização de tal quadro.

Ora, a voz, por ser um atributo representante individualizado do desenvolvimento do ser humano, desde o nascimento (BEHLAU e PONTES 1995), oferece a possibilidade de estar com a qualidade reduzida, também pela dependência hormonal, implicando alterações que são iluminadas e explicitadas por pressupostos sociais, quando tomadas inclusas na linguagem cotidiana e na cultura de uma comunidade.

As características vocais estão, a propósito, sempre permeadas por valores pessoais e sociais que formam o ethos de um povo ou de uma comunidade. Embora, sendo utilizadas cotidianamente, essas propriedades tomam a forma de não-consciência, da qual HABERMAS (1993) relata;

A prática cotidiana orientada pelo entendimento está permeada de idealizações inevitáveis. Estas simplesmente pertencem ao médium da linguagem coloquial comum, através do qual se realiza a reprodução de nossa vida.[...] isto é, [...] os conteúdos normativos encontráveis em nossas práticas, dos quais não podemos prescindir, porque a linguagem, junto com as idealizações que ela impõe aos falantes, é constitutiva para as formas de vida socioculturais.

Desta forma, a voz estudada pelo viés da cultura e da linguagem, como ação comunicativa, pode ser capaz de exibir manifestações próprias de um grupo 
com caracteristicas comuns, para além da análise estética ou da profissionalização, embora, segundo PENTEADO (2003), cada pessoa reaja de uma maneira particular no processo de adoecimento.

Embora os critérios de decomposição sejam pessoais, o enfoque é determinado socialmente e a função comunicativa da voz que enreda e trespassa o tecido da coletividade, é o amálgama que sustenta e fusiona um estabelecido código lingüístico, agindo em contraposição ou em consenso às informações transmitidas pelos elementos segmentais.

Essa disposição possibilita entrever que "...o sentido de convivialidade que fazia do privado e do público não termos opositivos, mas congeniais" (PAES 1997, p.13), herança da pólis grega, é mantido ainda hoje, em relação à voz, e aparentemente se solidifica quando na eleição de um grupo mais específico, como o de mulheres na pós-menopausa, desinência do climatério.

Assim, a voz e a ocorrência de alterações vocais no período da pósmenopausa, como em outros períodos críticos, possibilitam uma sinergia de conhecimentos que revela a complexidade encerrada nesse objeto.

A propósito, temos em uma investigação, elementos que se relacionam e determinam o rumo desses conhecimentos, podendo ser resumidos na seguinte circunstância para este estudo: 


\section{Figura 2 - Relação entre os determinantes da pesquisa}

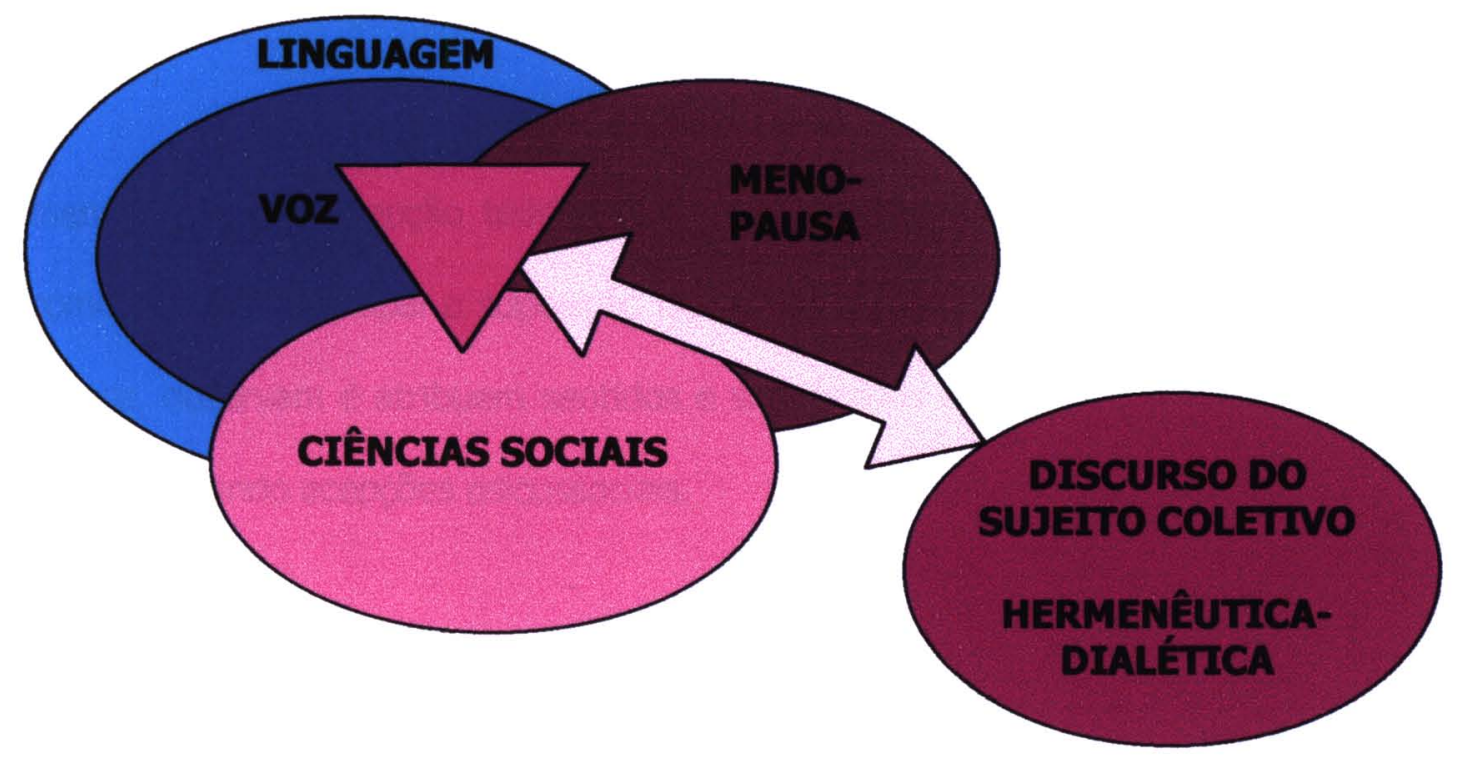

Nesse sentido, o presente empreendimento, de certa forma muito ambicioso, tencionou esquivar-se do lugar comum proposto pela Fonoaudiologia, analisando um segmento da sociedade pouco explorado por seus profissionais (mulheres após a menopausa). Inseriu um campo fonoaudiológico em outro (voz em linguagem, assumida como linguagem do cotidiano), exercitando a vinculação entre os diversos conhecimentos por uma aproximação às Ciências Sociais. Pretendendo investigar sob as concepções da pesquisa qualitativa, foi aplicada uma metodologia para descrição e análise, aparentemente ainda inédita nos estudos circunscritos da Fonoaudiologia - o Discurso do Sujeito Coletivo. Para as interpretações, cultivaram-se aproximações à hermenêutica-dialética.

A expectativa, com este estudo, foi, por seu turno, propiciar aos fonoaudiólogos uma abordagem que privilegie a voz na interação social, e mais que 
isso, na comunicação, na linguagem ordinária do dia-a-dia. Ao mesmo tempo, a médicos ginecologistas e gineco-endocrinologistas, possibilitar uma advertência sobre a importância da voz na vida cotidiana das mulheres e salientar a complexidade que envolve a saúde vocal.

Assim, tendo sido delineados os pressupostos em relação à voz e à menopausa, a concepção teórica deste trabalho evidencia a sua natureza: adota como hipótese principal a suposição de que as mulheres, mesmo não profissionais da voz, observam e atribuem sentidos e significados à voz, para além da fisiologia vocal, atingindo acepções psicossociais. 
O rigor de uma ciência é diretamente proporcional à rotina do objeto.

Rubem Alves (escritor) 


\section{II - OBJETIVO}

Para compor e estudar o objeto em destaque - a voz da mulher após a menopausa - fundamentada por reflexões oriundas de uma interpelação às Ciências Sociais, propôs-se nesta pesquisa:

Analisar os sentidos atribuidos à voz e às mudanças vocais ocorridas após a menopausa por participantes do Programa de Saúde da Mulher no Climatério. 


\section{III - METODOLOGIA}

Só uma pessoa muito delicada pode entrar num quarto vazio onde há um espelho vazio, e com tal leveza, com tal ausência de si mesma, que a imagem não marca. Como prêmio essa pessoa delicada terá então penetrado num dos segredos invioláveis das coisas: viu o espelho propriamente dito.

Clarice Lispector 


\section{III - METODOLOGIA}

\section{Desenho do Estudo}

A pesquisa foi iniciada coletando-se os dados de interesse de 148 mulheres nos prontuários médicos, entre fevereiro de 2000 e outubro de 2001, no Programa da Saúde da Mulher no Climatério, do Ambulatório de Ginecologia da Irmandade Santa Casa de Misericórdia na cidade de Curitiba, capital do Paraná.

Dentre a população total, selecionamos, intencionalmente, 58 mulheres dentro dos critérios estabelecidos, que foram sendo convidadas a participar das entrevistas conforme compareciam para as consultas do Programa. Com as voluntárias empregou-se a técnica de Entrevista (ANEXO I), permitindo uma exploração em profundidade dos depoimentos, devido a qualidade essencial interativa desse processo, assumido como o recurso mais apropriado para promover a compreensão dos sentidos atribuídos à voz e às mudanças vocais que ocorrem após menopausa.

Dada a ampla natureza do objeto abordado - a voz humana pretendemos no presente trabalho, essencialmente a adoção de uma metodologia qualitativa, que possibilita a ênfase nas especificidades complexas concedidas pela articulação das margens biológica, social e psíquica de abrangência desse fenômeno, principalmente quando o interesse do investigador é a compreensão dos significados atribuídos pelos sujeitos sobre um tema peculiar estudado, segundo ALVES-MAZZOTTI E GEWANDSZNAJDER (2000).

A pesquisa qualitativa, tendo um caráter inovador, remete à dimensão cultural de um conjunto de práticas, com um campo significativo de trabalho na sua 
dimensão política. Como uma construção coletiva, vai se realizando por recursos de complementaridade e não de exclusão, pois o sujeito é ativo e com experiência social que, na relação com a prática do profissional, dá um sentido de aprofundamento ao saber e à aplicação dele, retornando aos implicados de forma crítica e criativa, conforme MARTINELLI (1999).

DINIZ (1999, p. 52) refere que é "a dimensão epistemológica que garante a objetividade da realidade investigada e o esforço metodológico de fidelidade à realidade".

Dessa forma, realizar 0 estabelecimento dos pressupostos rīetodológicos garante a dimensão epistemológica e a observância da exatidão para apreender e compreender a realidade investigada.

\section{1a. Grounded Theory}

Partindo-se do pressuposto que "as pessoas agem em função das suas crenças, percepções, sentimentos e valores e que seu comportamento tem sempre um sentido, um significado que não se dá a conhecer de modo imediato, precisando ser desvelado" (ALVES-MAZZOTTI e GEWANDSZNAJDER 2000, p.131), empregaram-se os referenciais das Representações Sociais.

Assim, a referência teórica para o desenvolvimento dessa investigação centra-se nos conceitos da Semiótica que alicerçam a Psicologia Social, vertente da qual derivam os pressupostos da Representação Social.

A concepção primordial refere-se à apreensão da realidade que não se dá de forma direta, mas é mediada pela capacidade de evocar imagens e símbolos, de atribuir significados, de criar, inventar, não reproduzindo apenas aquilo que está instituido, apresentando estruturas com duas faces indissociáveis: a figurativa e a 
simbólica (MOSCOVICI 1976). Tendo este caráter dinâmico que se reflete na construção da identidade, as representações carregam marcas singulares de grupos sociais, conflitos e contradições, nem sempre articulados coerentemente.

DURKHEIM, em 1957, primeiramente trouxe o conceito sociológico de dependência do plano perceptivo em relação à dimensão social, opondo-se às noções vigentes do inatismo, e MOSCOVICI (1972) foi aperfeiçoando de forma notável, desde 1961, a concepção de representação social, sem definições rígidas dos termos teóricos, favorecendo o impedimento da cristalização dos pressupostos fundamentais e oportunizando a abertura para uma 'grande teoria'(SÁ 1996, SPINK 1996). Preocupou-se em estabelecer uma dinâmica entre as dimensões individual e soxial, intermediada por um processo cognitivo, permeado pelos aspectos emocionais, afetivos e do inconsciente, na acepção freudiana. Apoiado em propostas piagetiana e vygostikiana, "buscou a gênese profundamente social da construção do saber [...] resgatou o entendimento de que o saber social é simbólico e, enquanto tal é de uma só vez produto da ação, da comunicação e da construção dó sujeito" (JOVCHELOVITCH 1998, p. 57). Essa diligência, conforme dispõe a realidade, institui significados ao relacionamento entre os integrantes de uma comunidade, permitindo a atividade comunicativa.

Assim, determina uma vertente européia da Psicologia Social, antitética à americana, principalmente por recuperar o caráter social, mediante a 'grande teoria', no sentido de proposição de conceitos básicos (em contraposição à microteorização) orientados pelo cognitivismo (que é diferenciado do cognitivismo individual e das relações sociais específicas americanos) e pelo historicismo (contrastando com o a-historicismo americano) dos fenômenos representacionais, conforme SÁ (1996). 
É possivel, portanto, igualmente a QUEIROZ (2000), definir representações sociais como "conhecimentos culturalmente carregados, que adquirem sentido e significado pleno no contexto sócio-cultural e situacional em que se manifestam" (p.365).

Para MINAYO (1994, p.158), as representações sociais são definidas nas Ciências Sociais como "categorias de pensamento, de ação e de sentimento que expressam a realidade, explicam-na, justificando-a ou questionando-a", que se manifestam em condutas da linguagem do senso comum, "tomada como forma de conhecimento e de interação social" na vivência cotidiana (p.173). Não são necessariamente conscientes, apresentando diversidade na nitidez e intenção.

A implicação de transparência absoluta dos sujeitos sociais, se e quando aplicada sem a crítica e a reflexão quanto ao conteúdo e instrumentalização, torna polêmica a utilização diversificada das representações sociais. Contudo, não se pode negar o mérito conferido pelo seu emprego por autoridades de prestígio, como princípio norteador de estudos valorizados na área da saúde e doença, conforme advertem CARDOSO e GOMES (2000).

Para capturar as categorias, a metodologia empregada para descrição e análise é a coletivização da expressão do pensamento que conforma o Discurso do Sujeito Coletivo, entidade artificial, cujo objetivo é reconstruir o imaginário social ou coletivo, em que "as formações sociais e as culturas falam através das práticas discursivas das pessoas que compõem estas sociedades e culturas" (LEFÈVRE e LEFÈVRE, 2000, p.6). 


\section{1b. Hermenêutica - Dialética}

Para interpretação do material coletado, socorreu-se à hermenêuticadialética, conforme apresenta MINAYO (1994, p.218), ou seja," como um caminho do pensamento, uma via de encontro entre as ciências sociais e a filosofia".

Vią de regra, para HABERMAS (1987), a hermenêutica é capaz de propiciar reflexões sobre a objetividade da práxis na compreensão da comunicação, ou seja, dos sentidos formados na relação cotidiana entre os seres humanos, pertinentes a um determinado tempo histórico. Fundamentado pelo marxismo, o termo práxis traz uma conotação de condições indispensáveis à sociedade, criadas por meio do conjunto de atividades que tem por finalidade a produção. Portanto, a leitura simplista da conexão entre a aparência do dado e o enunciado teórico, e a concepção da verdade extra práxis são rejeitadas. Nesse sentido, ação é o elo entre a hermenêutica e a dialética.

A dialética é adotada tendo em vista que, para compreender a realidade, a racionalidade torna-se produto da ação humana e tanto pode reunir quanto dissociar durante o exercício da crítica, sendo que "a tradição cultural que se expressa na linguagem está marcada pelo caráter ideológico das relações de trabalho e poder" (MINAYO 1994).

Diante disso, a linguagem conduz a conotações e significados que pedem ser consensuais ou conflitivos, compondo um índice de reificação e de dominação nas relações de trabalho e de poder. Um exercício crítico de comunicação recorrerá aos métodos interpretativos de transformação do objeto e do próprio exercício. 
Ainda de acordo com MINAYO (1994), o texto (unidade de análise) passa a ser "a representação social de uma realidade que se mostra e se esconde na comunicação".

Portanto, não obstante a maneira como PITTAM (1994) esclarece questões relacionadas à identidade, atitude, a influência dos estados emocionais, na relação entre falante - ouvinte, como uma face subjetiva dos valores culturais, sua perspectiva fundamental difere da teoria da ação comunicativa adotada nesse estudo, por estar pautada em uma vertente mais próxima da Psicologia Social norte-americana (SPINK 1996). Em especial, pelo fato de que Habermas, um niiósofo sistemático, isto é, integrador das grandes linhas teóricas, transita por uma piuralidade de conceitos psicossociais e lingüísticos, assentando suas concepções na experiência proporcionada pela vinculação intuitiva da razão estética e da razão comunicativa na harmonização dialética dos valores, ou seja, a racionalidade estética reunirá a reflexão e a crítica discursiva à experiência vivida e à compreensão cotidiañạ.

Asssim, a ação comunicativa, a competência lingüística, é sempre uma passibilidade imanente para a humanidade, capaz de promover consensos e de realizar discursos argumentativos, dentro dos quais a voz, representante individual e social, está contida como um dos elementos de desempenho cotidiano. Dai, a dẹscrição e a análise se centrarem em representações sociais, e a interpretação adotar as noções da hermenêutica-dialética, de permeabilidade entre linguagem e práxis. 


\section{Critérios e Procedimentos Para a Seleção dos Sujeitos}

Dentre os 148 prontuários, foram selecionadas e entrevistadas 30 mulheres, todas voluntárias, que não se consideravam profissionais da voz, estavam em uma faixa etária entre 48 e 59 anos, e no mínimo há doze meses sem menstruação (amenorréia), caracterizando a instalação de uma nova fase da vida - a menopausa. O grupo formou, portanto, uma amostragem por conveniência, ex-postfacto. A independência às quaisquer outras variáveis, residiu na relevância da investigação centrar-se na análise de discursos representativos, em relação às suas vozes, suscitados nessas mulheres pela passagem da privação hormonal e as possiveis aiterações daí advindas.

O início da faixa etária foi estabelecido como critério de seleção dos sujeitos do estudo, tendo em vista que a média de idade de ocorrência da menopausa no Brasil é de 48,1 anos, "sendo que $74,8 \%$ das mulheres apresentaram menopausa aos 50 anos ou menos, e 25,2\% apresentaram com 51 anos ou mais" [...] De um modo geral, a menopausa natural ocorre ao redor dos 50 anos (FONSECA e col.1985). O término da faixa foi fixado pela determinação do Ministério da Previdência e Assistência Social de entrada, aos 60 anos, em um outro grupo etário denominado terceira idade, quando são mais considerados os processos de senescência, próprios da espécie humana.

Embora a representatividade não seja preocupação para a metodologia qualitativa, por seu caráter compreensivo e não quantitativo, foram entrevistadas 30 minheres, que representou $20.27 \%$ da população total estudada e atendida no Ambulatório, até a data da última entrevista (29/10/01). O critério levado em consideração para manutenção da continuidade e extensão do convite foi a circularidade e repetição das respostas. Tendo em vista que o estudo interessou-se 
pela profundidade da concepção na construção do cotidiano individual do grupo investigado, compreender particularmente um grupo, permite que os conhecimentos sejam expandidos para outras populações, como parâmetro comparativo.

\section{Processo de Coleta de Dados}

No processo de coleta foi utilizado um Roteiro Temático semiestruturado, constando de quatro questões abertas básicas (em ANEXO I), que deram oportunidade de aprofundar o procedimento de compreensão dos significados atribuídos à voz e à menopausa, de cada entrevistada. Para cada depoimento observaram-se os critérios estabelecidos no Termo de Compromisso Ético (ANEXO iii), tendo sido o Consentimento Livre e Esclarecido (ANEXO IV) assinado apenas ao final da entrevista, quando ficava evidente do que se tratava a pesquisa e as mulheres podiam optar autonomamente pela manutenção ou não das informações discursivas. A decisão foi tomada, também, em razão da resistência de uma parte das mulheres que temiam algum tipo de prejuízo, principalmente econômico, quando da assinatura anterior ao depoimento.

Durante as entrevistas, sempre que necessário para entender o significado individual empregado, era realizado questionamento que eliciasse uma resposta explicitadora. Por exemplo: quando a entrevistada dizia que era 'uma voz feia', a pesquisadora a incentivava a esclarecer, de alguma forma, como era uma voz feia para ela, especificamente.

Os depoimentos foram tomados enquanto as mulheres aguardavam sua vez na sala de espera, ou após a consulta com o médico ginecologista. No início, foram marcadas, por telefone, algumas entrevistas, independentes do horário com o médico, na tentativa de agilizar o processo de coleção das declarações. Porém, como estava 
gerando desconfiança, temor e tensão em participantes, que ficavam preocupadas e buscavam certificar-se com a médica responsável pelo Ambulatório de Climatério sobre a seriedade desta pesquisa, houve, por bem, continuar as entrevistas somente nos horários das consultas médicas.

Enquanto essas se mantiveram no prédio da Santa Casa, as mulheres eram entrevistadas, isoladamente, em qualquer sala disponivel no momento, contudo, com a mudança ocorrida para um prédio utilizado pelo SUS (Centro de Referência de Especialidades - CRE), a única possibilidade era tomar os depoimentos individuais na própria sala em que cada médico residente realizava a anamnese de sua paciente, buscando-se a mesa mais resguardada para manter a privacidade das depoentes no momento de maior vulnerabilidade, em que poderiam ser vinculadas às suas narrativas.

Cada entrevista foi gravada e transcrita, respeitando as peculiaridades de expressão discursiva dos sujeitos implicados. As transcrições foram, então, enumeradas de 01 a 30 e designadas por nomes de mulheres das composições de Chico Buarque de Holanda, preservando a identidade pessoal.

Para estruturar o quadro de caracterização da população (ver em Resultados) foram associados dados dos prontuários das mulheres entrevistadas e declarações de interesse dos depoimentos (Alteração vocal na menopausa e Autoimagem vocal) para a descrição. 


\section{Descrição da metodologia aplicada}

Dentre as representações sociais, a utilização da Análise do Discurso do Sujeito Coletivo foi a opção para desenvolver o tema, pois, para LEFĖVRE e LEFĖVRE (2000) "o pensamento de uma coletividade é composto pelos discursos ou matrizes discursivas disponíveis nesta sociedade" (p.1). A abordagem qualitativa permite a compreensão mais profunda da intencionalidade e do significado, conferindo proeminência e naturalidade aos discursos (LEFĖVRE e col. 2000) que irrompem, reprimem ou moldam as relações das pessoas.

A expectativa era a de que os elementos qualitativos coletados, depois de transcritos e analisados, permitissem a apreensão do significado dos núcleos ou matrizes discursivas das Representações Sociais, buscando-se, portanto, na metodologia de descrição e análise do Discurso do Sujeito Coletivo (ANEXO II), "resgatar o discurso como signo de conhecimentos dos próprios discursos" (LEFÈVRE e col. 2000).

Se, por um lado, os discursos abordados por um corte qualitativo "permitem a compreensão mais aprofundada dos campos sociais e dos sentidos neles presentes, na medida que remetem a uma teia de significados $[\ldots]^{\prime \prime}$, conforme LEFÈVRE e LEFÈVRE (2000, p.15); por outro lado, "uma pessoa é o imaginário social personificado" (p.5), isto é, comunica-se utilizando o "idioma ideológico disponivel, num dado momento, na sua cultura e na sua formação social" (p.6).

De acordo com os autores para assumir o discurso "como forma de expressão do pensamento social" (p.3) faz-se necessário "resgatar a fala do social" (p.3), somando qualitativamente os discursos e compondo o Discurso do Sujeito Coletivo, ou seja, agregando discursos individuais para formar um discurso geral ou o 
texto a ser analisado. Para tanto, foram observados e aplicados os conceitos-base da proposta metodológica: tema, expressões-chave, idéias centrais e ancoragem, por meio dos dois instrumentos de análise - Instrumento de Análise 1 e Instrumento de Análise 2.

Entende-se por Tema aquilo que "diz respeito ao assunto em pauta" (LEFÈVRE 2000, p.4), o objeto sobre o qual o depoente fala. No nosso caso, sobre voz e menopausa.

As expressões-chave são "pedaços, ou trechos, ou segmentos, contínuos ou descontínuos do discurso" (p.3) do entrevistado, selecionado pelo pesquisador, a partir da idéia do que seja essencial e acessório. São "concretas, expressivas, descritivas, abundantes, afetivas, literárias" (p.4). É exatamente o quê foi dito e transcrito a respeito do tema. Por exemplo: na Questão 1, Entrevista 9 (Q1E9) do Anexo II: Achu qui pra mim ta senu um períodu assim muituuu, di muito nervosismu.., queu achu qui não é normal... Fica nervosa assim, as vezes até por

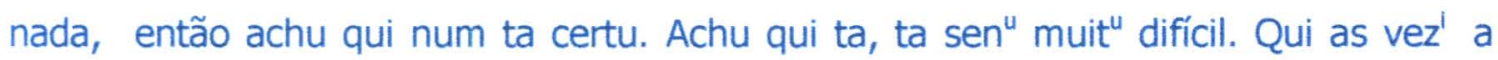
gente qué é dize qui é algum poblema, mas as veiz é poblema da gent mesmu, né? Eu achu qui é issu...

No corpus (ANEXO II), as "Expressões-chave" foram distintas por um tipo de letra e de cor, tornando mais visível a classificação para "Idéia Central" e "Ancoragem". Assim, à letra Tahoma corresponde a cor azul-claro, para assinalar as idéias centrais; e à letra Monotype Corsiva, a cor azul-escuro, correspondente às ancoragens. Algumas ancoragens representavam, também, idéias centrais.

Idéia Central é a "expressão lingüística que revela e descreve, da maneira mais sintética e precisa possível, o sentido, ou o sentido e o tema das expressões-chave de cada um dos discursos analisados e de cada conjunto 
homogêneo de expressões-chave" (p.4). É a síntese que o investigador realiza daquilo que o entrevistado quis dizer e, portanto, são "abstratas, conceituais, sintéticas, frias e poucas" (p.4). Em relação ao exemplo de expressão-chave citada (Q1E9), originaram-se duas idéias centrais:

(1) A menopausa está sendo um período difícil.

(2) Sente muito nervosismo que não acha certo, nem normal.

A Ancoragem é "a expressão de uma dada teoria, ideologia, crença religiosa que o autor do discurso professa e que está embutida no seu discurso como se fosse uma afirmação qualquer" (p.3). Logo, é a instância de representação dos conceitos sociais que movimentam os discursos, de forma não-intencional, embora estejam delineando o processo de comunicação; é uma generalização para enquadrar um evento particular, ou a particularização de uma generalidade. Um exemplo relativo à expressão-chave citada no Anexo II: (Q1E4) Agora pra mim eu num,.. eu num senti aqueles calor, aquelas coisa qui nem as mulher falam. $\mathrm{Na}$ ancoragem salientada dessa expressão-chave - "A menopausa não é igual ao que todos dizem" - há a particularização daquilo que ela assume como uma generalidade (as mulheres dizem, eu não sinto) a respeito da menopausa. Enquanto, por exemplo, na Q1E6 Afw.. a minfia dificuldade dela é qui.. é qui as mulher ingorda... Ainda bem que eu não preciso repor hormônio... Qui eu precisassse aí ia ficar difícil... Porque dai queu ia ingorda mesmo... trouxe a ancoragem "Todas as mulheres sofrem os sintomas igual a mim" em que é adotada a generalização de um evento particular (eu engordo na menopausa, todas as mulheres engordam também).

O Discurso do Sujeito Coletivo é conceituado, então, por LEFÈVRE e LEFÈVRE $(2000$, p.6) como "descrição ou representação discursiva do imaginário social" no qual o pesquisado é "o imaginário social personificado" e o papel do 
pesquisador em representações sociais é o de "reconstruir este imaginário a partir dos pensamentos expressos pelos indivíduos".

No primeiro instrumento - Análise do Discurso 1 - composto por expressões-chave, idéias centrais e ancoragem, que pode ser visualizado no exemplo abaixo, no qual se estrutura a análise e categorizam as idéias centrais e ancoragens.

Assim, retomando, após a transcrição dos depoimentos foi transferido para o Instrumento de Análise do Discurso 1 (IAD1) as trinta respostas para cada uma das quatro questões, nas caselas "expressões-chave". Em seguida, utilizandose de leitura das trancrições e escuta das fitas gravadas, buscaram-se referências lingüísticas segmentais e supra-segmentais, gramaticais fonética, morfológica e sintática para estabelecer a(s) "idéia(s) central(ais)" e as "ancoragens" que se evidenciavam, sendo anotadas nas devidas caselas e categorizadas, segundo os mesmos critérios lingüísticos e gramaticais, por semelhança de sentidos. Exemplo: Q1E6

\section{Instrumento de Análise 1}

\begin{tabular}{|l|c|c|}
\hline $\begin{array}{l}\text { EXPRESSÕES - CHAVE Questão1 } \\
\text { Como está sendo a menopausa para você? }\end{array}$ & IDÉIAS CENTRAIS & ANCORAGEM \\
\hline
\end{tabular}

6E Ahr, a minha dificuldade dela é qui..., é qui as mulheringorda, né dotora? Ainda 6em que eu num preciso repor hormônio, né? Qui eu precisasse aí ia fica dificil, né? Purque dá queu ia ingorda mesmo, né? , e até mi deu remédio i tudo, né? Eu num tomei, não. Aí..., claru nunca eu precisei dissu, né? Nunca tomei anticoncepcional, então agora num vo toma, né? To na menopausa, né? Num precisu toma. Então, dotora, a dificuldade minha é esse negóciu di cria mais é.. seiu, quadril, essas coisa, né? Só minha dificuldade é essa, purque eu perdi toda minha ropa. Então a dificuldade é essa....

(1) Engordou, criou seio, quadril. E (2) Apesar de difícil, acha bom não ter que repor hormônios para não engordar mais, pois perdeu todas as roupas. Fez todos os exames, estava tudo bem e acha que como nunca precisou tomar anticoncepcional também não precisará de hormônios agora (na menopausa)
Todas as mulheres sofrem os sintomas igual a mim. B 
No segundo instrumento - Análise do Discurso 2 - as expressões-chave estão categorizadas, formando grupos que foram denominados segundo as idéias centrais e as ancoragens.

A categorização (em letras maiúsculas do alfabeto, em vermelho, representada pela letra Tahoma, para as idéias centrais e, em rosa, representada pela letra Lucida Handwriting, para as ancoragens) possibilitou uma denominação para cada grupo, sendo sintetizada por uma frase, constituindo uma categoria empírica. Exemplo: A letra "B" da Idéia Central da Q1E6 acima, foi denominada, junto às demais com o mesmo sentido, como: "A menopausa é um período difícil de ser enfrentado".

Cada frase tornou-se representativa das "expressões-chave" de mesmo sentido no Instrumento de Análise do Discurso2 (IAD2). Um exemplo pode ser ànalisado abaixo, na Q2:

\section{Instrumento de Análise 2}

$\mathbf{E}=$ Experiência profissional com o assunto

\begin{tabular}{|c|c|}
\hline EXPRESSÕES - CHAVE & DISCURSO DO SUJEITO COLETIVO \\
\hline $\begin{array}{l}\text { (1) Quanu tava... um ano atrás eu fazia } \\
\text { parte do coral... Então a gente... fazia } \\
\text { ensaio, é... a minha... professora disse } \\
\text { que gostava da minha voz, apesar qui eu } \\
\text { dizia que não, mas, eu gostava de } \\
\text { cantar, ia lá e ensaiava dipois a genti... } \\
\text { é... cantava, apesar qui vai cantar prá } \\
\text { Jesus... Cantora não... No coral assim } \\
\text { não dá pra vê a voz direto... } \\
\text { (5) Eu traba...eu também faço muito... } \\
\text { física (exercícios), massagi na garganta. } \\
\text { Num sei si issu ajuda também.... purque } \\
\text { te ajuda abri... canais, não dexa tranca a } \\
\text { voz, achu que muda purque eu fico } \\
\text { cuidando tamem... alimentação.... não } \\
\text { que tivesse que eu faze, mas eu sei qué } \\
\text { bom, então a genti obedeci. }\end{array}$ & $\begin{array}{l}\text { Há um ano atrás eu fazia parte do coral. } \\
\text { Havia ensaios e a professora gostava da } \\
\text { minha voz. Não que eu fosse cantora } \\
\text { porque em um coral não dá para ouvir a } \\
\text { voz individual. Eu faço exercícios e } \\
\text { massagem na garganta para não trancar } \\
\text { a voz e cuido da alimentação porque eu } \\
\text { sei que é bom e obedeço. }\end{array}$ \\
\hline
\end{tabular}


A ordenação em uma sequiência lógica para a conformação do Discurso do Sujeito Coletivo (DSC) seguiu um esquema clássico de estruturação das narrativas, utilizando todo o material das expressões-chave: começo, meio e fim, atuando sobre o mais geral para o mais particularizado. A ligação entre as partes do discurso ou parágrafos foi realizada introduzindo-se conectivos como: assim, então, logo, enfim, entre outros. Foram eliminados os particularismos de idade, parentescos, eventos, doenças, como parte do processo denominado desparticularização (LEFÈVRE e LEFÈVRE 2000). Igualmente, foram eliminadas as repetições de idéias, porém não aquelas expressas de modos ou com palavras ou expressões distintas, ainda que semelhantes, sobre o mesmo sentido.

A partir dai, assumindo-se a liberdade de interpretação propiciada pela ground theory, as referências, parâmetros e os fundamentos das Representações Sociais, as concepções de comunicação e da hermenêutica-dialética de Habermas, os discursos conformados foram analisados por meio de uma semântica relacional elementar para cada categoria empirica criada. A crítica dialética "enfatiza a diferença, o contraste, o dissenso e a ruptura de sentido", enquanto a hermenêutica "destaca a mediação, o acordo e a unidade de sentido" (MINAYO 1994). Dessa forma, HABERMAS (1987) reconhece na hermenêutica-dialética o pensamento ético-político na práxis social, objeto de sua análise.

Em suma, abaixo, são apresentadas as etapas seguidas, em conformidade à metodologia do Discurso do Sujeito Coletivo: 
Figura 3: Sumário das etapas para aplicação do Discurso do Sujeito Coletivo

1. Entrevistas e transcrição integral das respostas

2. Cópia no Instrumento Análise do Discurso 1 das respostas integrais na coluna "Expressõeschave"

3. Leitura e escuta para identificação das "Idéias Centrais"e das "Ancoragens"

4. Transposição das "Idéias Centrais" e das "Ancoragens" para as caselas correspondentes

5. Categorização das "Idéias Centrais"e "Ancoragens" de mesmo sentido

6. Denominação de cada grupamento

7. Transposição das "Expressões-chave" de cada grupamento do Instrumento de Análise do Discurso 1 para a coluna "Expressóes-chave" do Instrumento de Análise do Discurso 2

8. Construção do Discurso do Sujeito Coletivo de cada grupamento

9. Análise dos discursos coletivos 


\section{IV - RESULTADOS}

Dados são apenas provocações - peças avulsas de um quebracabeça - que sacodem a imaginação, pedindo que ela resolva o enigma.

Rubem Alves (escritor) 


\section{IV - Resultados}

O perfil da população foi adotado como resultado dos dados dos prontuário das mulheres entrevistadas, somados à duas questões retiradas dos depoimentos e que, portanto, constituem representações particulares.

Sendo as representações sociais uma "teoria sobre a produção dos saberes sociais", sobretudo os saberes que se produzem no cotidiano (JOVCHELOVITCH, 1998, p.55), tornou-se de considerável valor caracterizar o grupo de mulheres estudadas, para auxiliar a compreensão das representações obtidas.

Além disso, buscamos estabelecer alguns hábitos que poderiam estar repercutindo diretamente sobre o funcionamento da laringe, para possibilitar a visualização dos estilos de vida, permitindo compreender a influência, sobre a voz, ao longo da vida. 


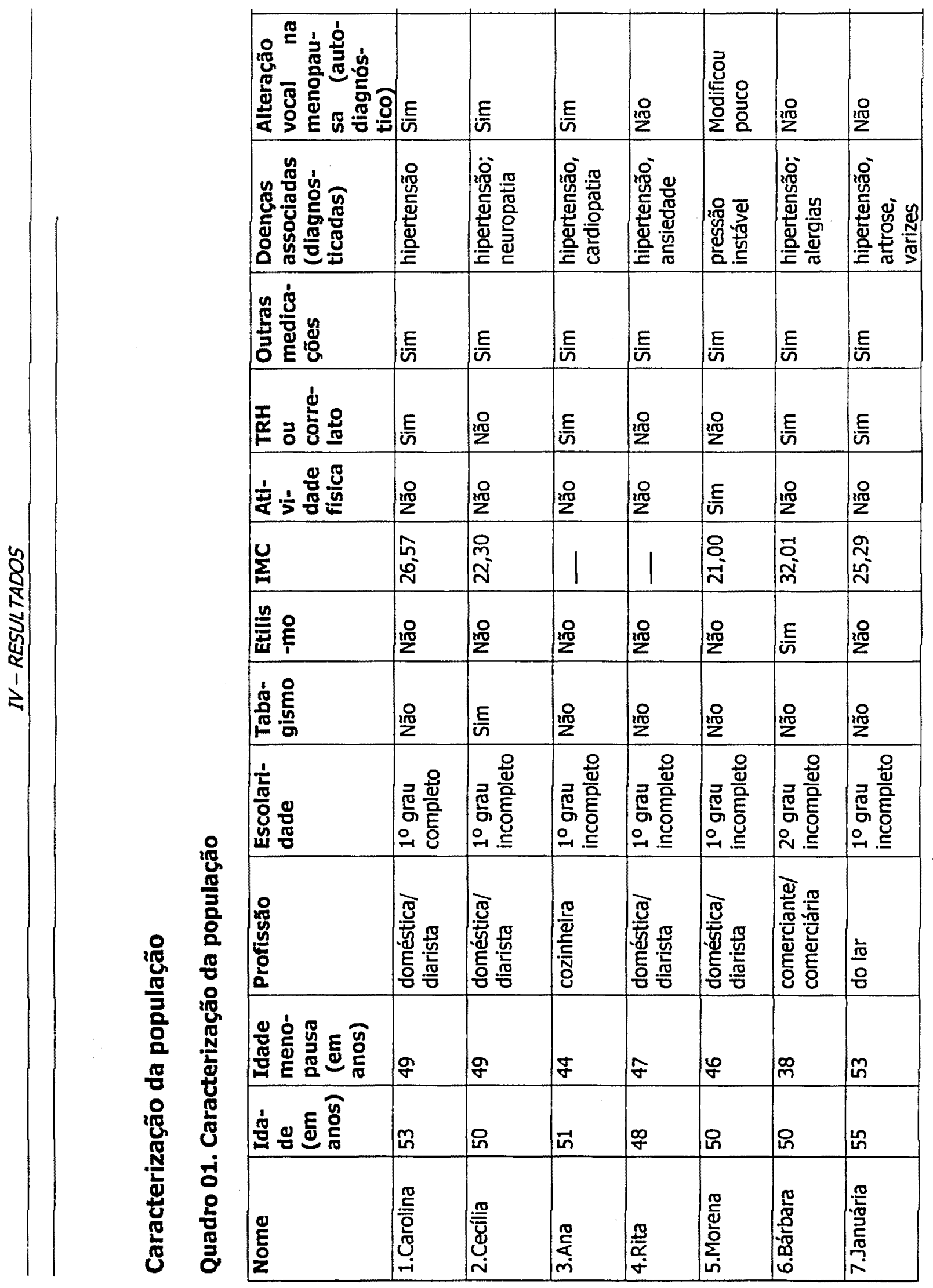




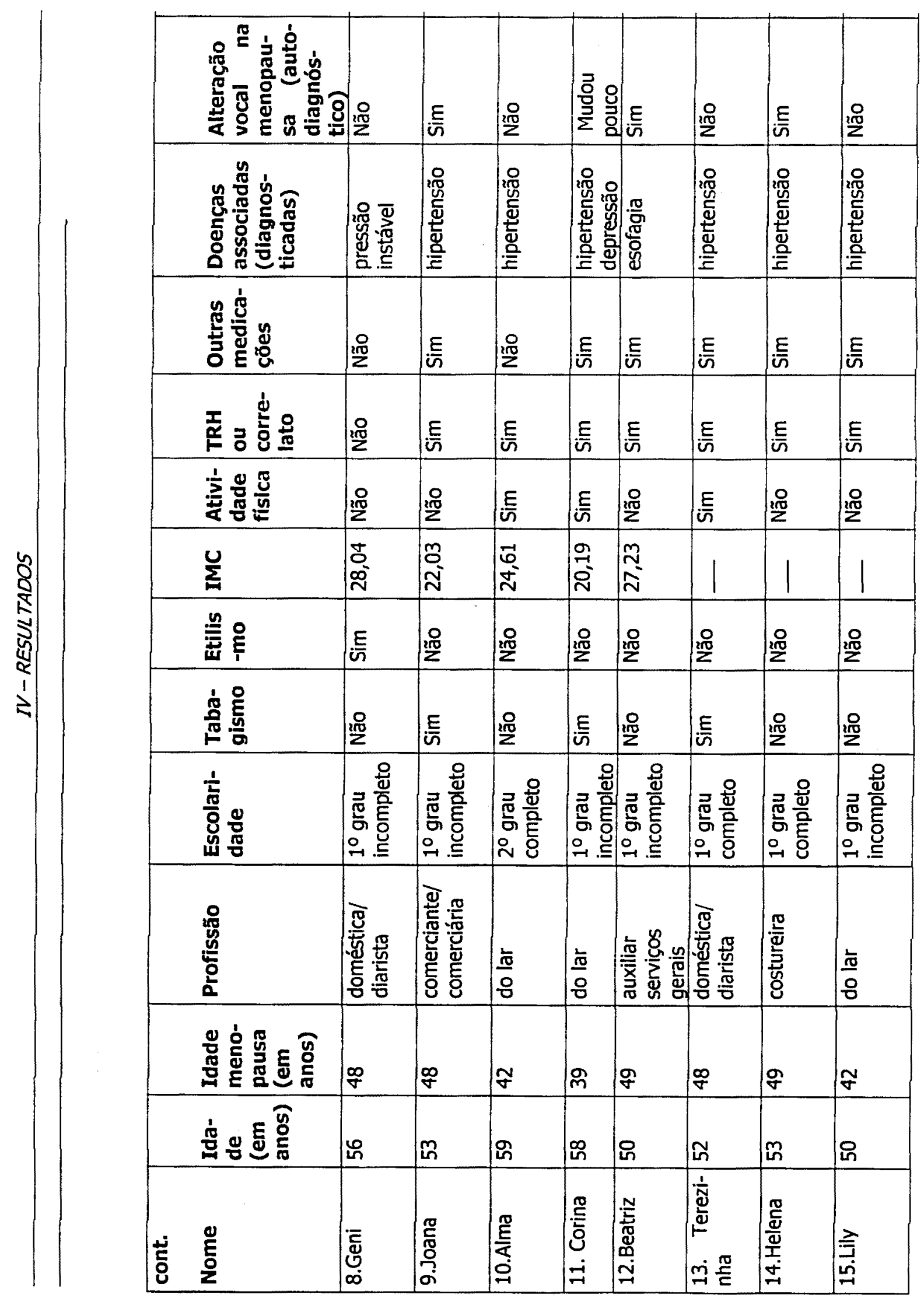




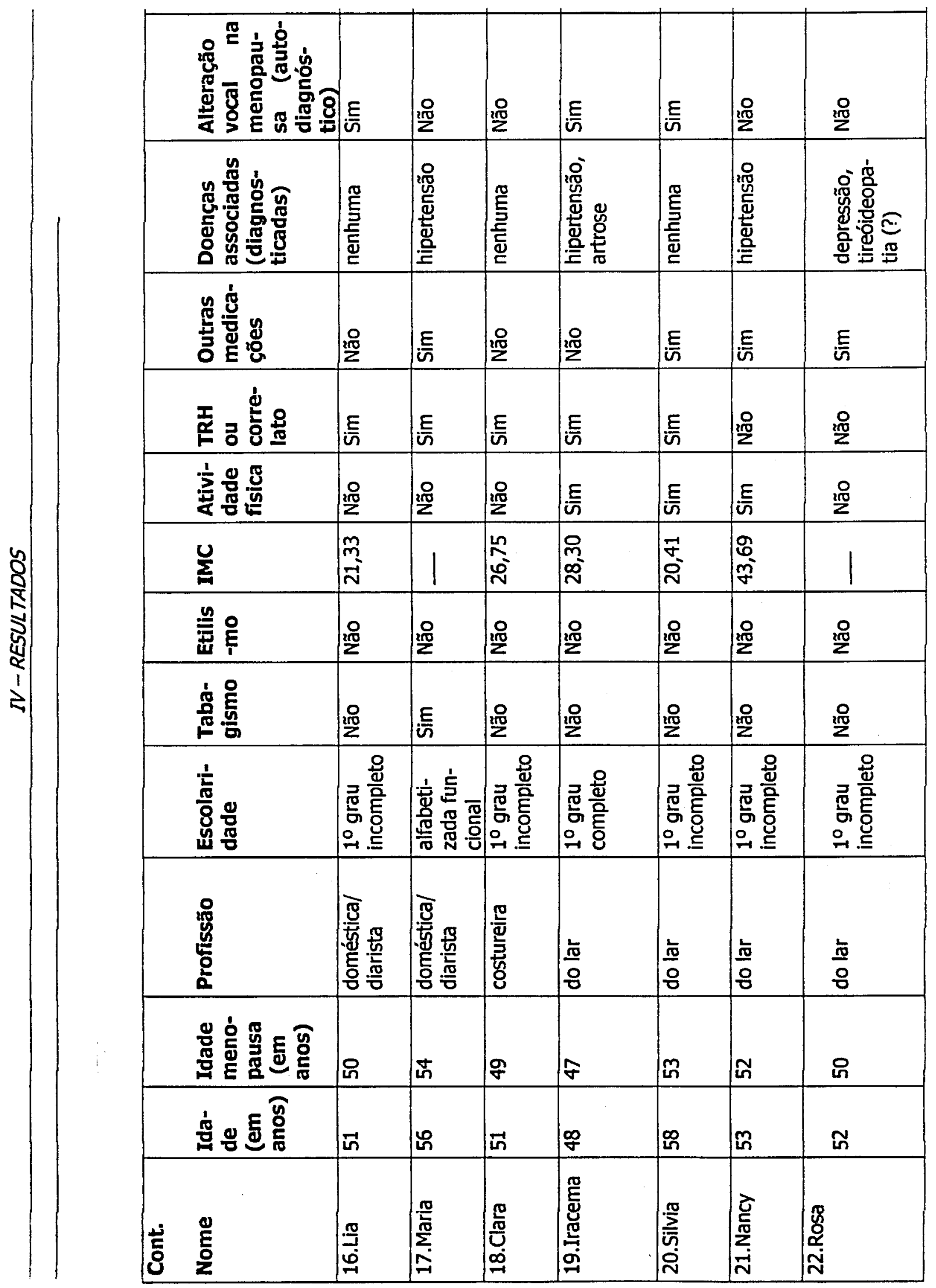




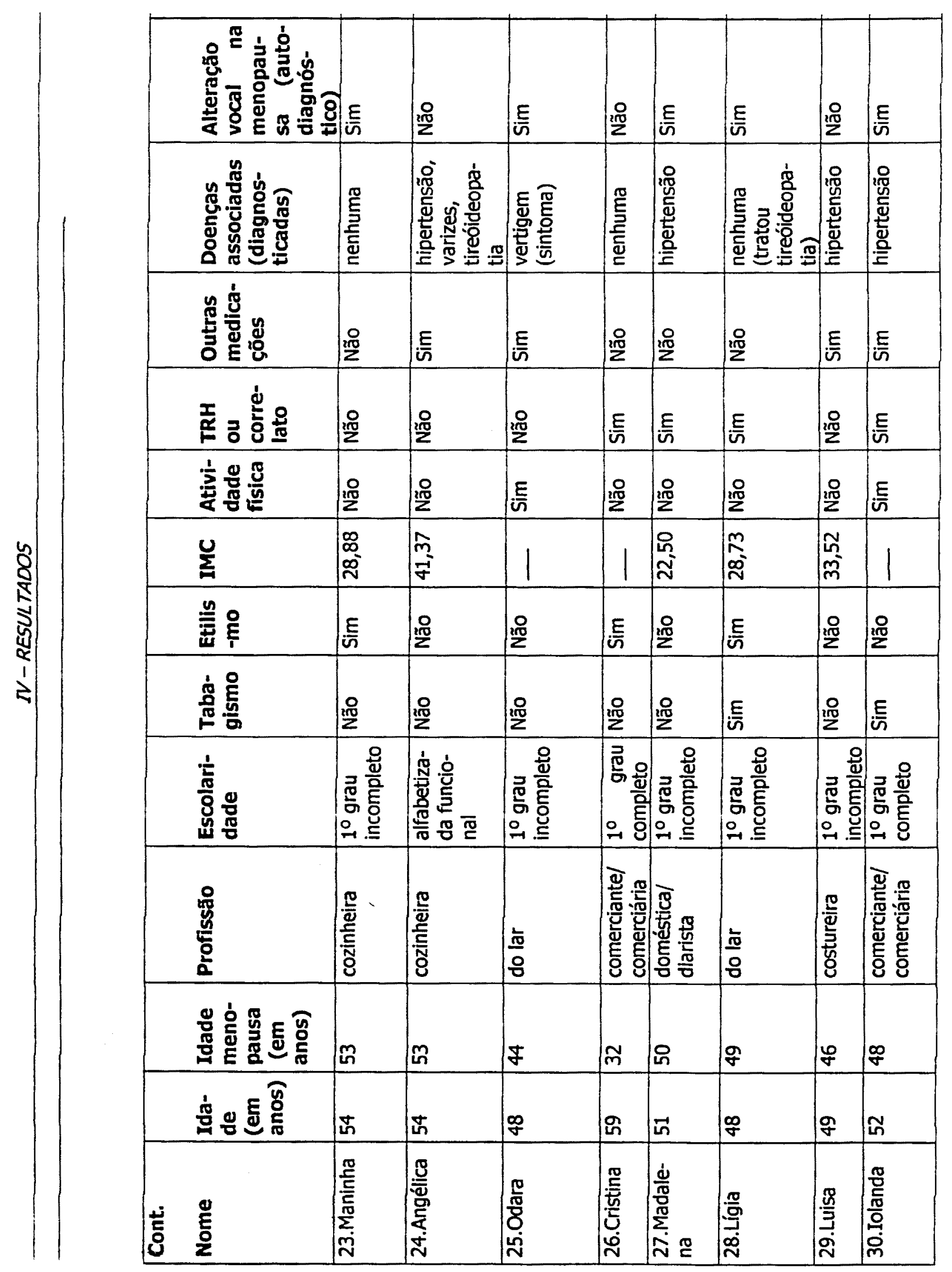


Em relação aos discursos, para os quatro grupamentos ou temas foram estruturados (27) vinte e sete discursos coletivos, a seguir:

Em relação à Questão 1- "Como está sendo a menopausa para você?"as idéias centrais constituíram seis discursos distintos:

Discurso 1.A: "A menopausa não é um periodo tão dificil de ser enfrentado"

Não deu para sentir, porque a menopausa não está sendo um bicho terrivel que todos dizem, não estou sentindo assim. Agora estão começando aqueles calorões famosos, está pouco ainda, está razoável e ainda estou dando conta do que sinto. Eu me sinto bem em tudo depois que parou a menstruação - natural ou cirurgicamente. Não posso reclamar. Na verdade eu não teria nem procurado o médico se alguém não tivesse insistido, porque eu me sentia bem. Enfim, não estou achando diferença.

Discurso 1.B: "A menopausa é um período difícil de ser enfrentado"

A menopausa é terrível, péssima, está sendo bem difícil, é um problema muito sério pensando no sofrimento que tive. Judiou bastante, tinha muita aflição, foi bem complicada, Nossa Senhora! Foi a coisa mais horrivel do mundo! Tive problemas de calorão, falta de ar, dor de cabeça, pressão alta, aumento de peso, chegando a perder todas as minhas roupas. Com o calorão e a insônia incomodava o marido de tanto que me movimentava à noite. Mas também é difícil para quem mora sozinha passar por todo problema. Por isso fui procurar tratamento há um tempo e só agora deu certo. Com o atendimento estou me sentindo bem, 
acalmou os sintomas, mas se não fosse a doutora acho que nem viva estava.

Discurso 1.C: "A menopausa é um periodo melhor que a fase reprodutiva"

O periodo de menopausa tem sido bom para mim: eu não tenho mais menstruação, mas a vida continua igual no casamento porque não tive problemas na área sexual, tudo continua da mesma forma, nada mudou. Antigamente, quando tinha a menstruação era difícil, muitas vezes tinha dores no corpo, muita cólica, indisposição. Isso é um incômodo, a gente tem aquela preocupação todos os meses. Agora que parou achei melhor ficar sem a menstruação. Eu não tenho nada, não me atingiu em nada, não tenho dor de cabeça, não tenho calorão, não tenho indisposição, me sinto super bem em tudo.

Discurso 1.D: "A menopausa com tratamento não é nada"

A mienopausa está sendo normal porque estou tratando. Desde que procurei tratamento passei a tomar o hormônio, o remédio que a doutora receitou e estou me sentindo bem melhor, ótima. Então, não pesa, está sendo sem problemas. Pouca ou muita tontura, dor de cabeça e embaraçamento da visão retornam se deixo de tomar a medicação. Enquanto realizava os exames para saber a necessidade e possibilidade de reposição hormonal tomava remédios para melhorar alguns sintomas. Chás caseiros e remédios da farmácia de ervas também dizem que ajudam a melhorar o calorão. Tomando hormônios ou usando adesivo o efeito pode não ser o desejado, mas pode aliviar as sensações e não ter 
mais problemas. A mudança de medicação ou de dose, ou ainda, parar de tomar o hormônio pode trazer de volta as más sensações. Ficar sem repor - hormônio pode deixar os ossos e os cabelos fracos, a pele feia, porém, às vezes a menstruação retorna e até a hemorragia. Agora eu estou me sentindo bem com o remédio que a doutora me receitou e acho que tem que controlar tomando hormônio para não começar tudo de novo; está normal porque estou tratando.

Discurso 1.E: "A menopausa apresenta sinais e sintomas biológicos"

Na menopausa (natural ou cirúrgica, em tempo ou precoce) o calorão pode ser aquele comum que eu já sentia normalmente não conseguindo usar roupas fechadas; ou o calorão famoso, como as mulheres falam, que dá suador, e pode ser seguido de frio, ou que aparece nas costas e sobe para a cabeça, ou ainda aquele que precisa tomar banho duas, três vezes ao dia, mesmo no inverno. Além dos calorões, depois que entrei na menopausa fiquei com excesso de peso, precisando controlar o quê e quanto comer. A pressão (arterial) ficou instável ou alta, podendo infartar. Tenho canseira (ou fadiga) e falta de ar. Às vezes, a menopausa inicia com cólicas e peso abdominal, hemorragia vaginal ou nasal que levam a uma anemia e uma fraqueza profunda. As varizes dolorosas, causadas pela menstruação suspensa, e os problemas de bexiga aparecem e perturbam a rotina da vida, ou às vezes, como as hemorragias, necessitam de cirurgias. Pela orientação que tenho assistido na televisão, se é normal ou não o que estou sentindo, todio mundo sente a mesma coisa que eu sinto, e passa por essa fase dificii. 
Discurso 1.F: "A menopausa traz também resultados psicossociais"

Não sei se os sintomas orgânicos causam nervosismo ou se são causados por ele, mas, a diferença é que estou mais explosiva, mais irritada, triste, aflita, infeliz, chateada, aborrecida, perturbada, não tenho mais aquela paz e acho que tudo isso é devido à menopausa porque não tinha antes. Acho que deixa as mulheres aborrecidas, nervosas, com malestar ou aflição. A insônia, por causa dos calorões, incomoda também as pessoas com quem a gente convive e o marido precisa compreender a situação toda, inclusive sexual, para auxiliar. Não mudou a vida com o marido porque ele entende e tem um pouco de dificuldade por causa do problema cardíaco. Não tenho mais desejo sexual - tenho prazer, mas não mais aquela vontade como no começo do casamento, porém, cheguei perder o prazer de tudo. Pode ser a medicação conjunta que diminuísse o desejo, mas com o hormônio também não melhorou. Não esperava que fosse desse jeito porque não sou de fazer coisa errada, então quero dar um jeito de melhorar. Por isso eu resolvi procurar meios de tratamento para chegar na meia-idade mais feliz. No entanto, existem empecilhos, principalmente a demora, para marcar a consulta, os exames e os rêtornos, dificultando o tratamento e atrasando a resolução dos problemas. 
O Tema suscitou duas Ancoragens mais relevantes:

Discurso Ancoragem 1.A - "A menopausa não é igual ao que todos dizem"

Eu acho que, para mim, a menopausa não está sendo aquela coisa terrivel que todo mundo diz, não é aquele bicho. Não senti os calores nem aquelas coisas como as mulheres falam.

Discurso Ancoragem 1.B - "Todas as mulheres sofrem os sintomas igual a mim"

Todas as mulheres no começo do casamento sentem mais desejo sexual que na menopausa. Porém, engordar e sentir os calorões sempre dizem ser da menopausa. Então, eu acho que todo mundo sente as mesmas coisas que estou sentindo e passa por essa fase que eu estou passando.

Na questão 2 -"A voz das pessoas revela algo sobre elas, não é verdade? Fale sobre isso"- os discursos formados estão relatados abaixo:

Discurso 2.A: "Concordam com a afirmação"

Pode ser que tenha um fundo de verdade: o tom de voz faz com que se perceba como o outro está pessoalmente e até por telefone. Acho que conversando a gente vai se entendendo e vê como cada um é. Eu concordo, porque falando no dia-a-dia eu consigo demonstrar para as pessoas carinho, interesse, auxílio quando estão com problemas. 


\section{Discurso 2.B: "Discordância da afirmação"}

Eu acho que não. Agora você me pegou. Eu acho que não tem nada a ver uma coisa com a outra - a voz e revelação da pessoa. Na voz não, mas no rosto. Quando uma pessoa está enganando faz uma cara diferente. Eu percebo que os olhos da pessoa dizem muita coisa, porque se ela estiver falando a verdade tem que chegar e olhar bem nos seus olhos, assumir aquilo. Eu diria que a voz auxilia a dizer quem a pessoa é, mas são os seus atos, a maneira de se comportar, de viver que fala mais alto.

Discurso 2.C: "Considera-se sem conhecimento no assunto"

Não tenho noção do que a voz possa mostrar da pessoa. Não sei me expressar e explicar. Estou ficando nervosa e está me dando um "branco", não consigo responder sua pergunta. Não sei, nunca percebi, não notei que a voz fosse capaz de mostrar o que é a pessoa e não conheço quem diz isso.

Discurso 2.D: "Experiência leiga com o assunto"

Acho que tem pessoas que prevalecem (ficam arrogantes), quando estão acompanhadas de outras mais poderosas, querem deixar a gente menor que elas, e isso se percebe pelo tom de voz. Eu me sinto arrasada quando isso acontece. Pelo tom da voz eu percebo também se a pessoa é agressiva, é alterada. Quando a pessoa se altera, ela muda de voz: se está nervosa responde da mau jeito, e se está calma responde diferente, modifica mesmo. Assim, parece que conforme você conversa 
com a pessoa mais ou menos entende, sente, vê como ela é: má, mais ou menos ou melhor, com idéias melhores. Se ela é má, agride com palavras, se não vai com a minha cara, é melhor me afastar, não ficar perto. Eu converso, às vezes, com a vizinha e sinto na voz que ela está nervosa. A minha nora eu noto porque ela grita muito com o filho e se eu estou na casa deles é terrível, isso me deixa muito nervosa e me sentindo mal. Se estou nervosa a minha voz sai diferente, eu quase não consigo soltar a voz e se estou muito nervosa, não consigo falar, só choro. Eu acho que conforme a pessoa conversa é possivel perceber se gosta da gente, mas não se sente bem com quem parece que está com raiva. Às vezes, olhando uma pessoa a gente acha que ela é antipática, muito chata, mas conversando vemos que não é nada disso, que é uma pessoa muito boa. A gente vê que quando a pessoa está se sentindo bem, tem um jeito de conversar, de falar tudo, e aquela que não está se sentindo bem, tem um jeito diferente, tem dificuldade, é meio triste, meio aborrecida, reclama, e isso aparece na voz. Pode ser também da imaginação da gente ou porque sou meio parada no tempo, preferindo ouvir mais o que os outros falam, sem entrar em muitos detalhes. Não sei se isso é da minha natureza ou se é da educação que tive. Tem pessoas que quando falam deixam os outros agitados. Se a voz é muito estranha, eu sinto que incomoda. Parece que, conforme a pessoa fala muito ou assim de um certo jeito, incomoda. A minha filha fala muito forte, é o jeito dela, mas eu já faço sinal para diminuir. Ninguém se sente bem com uma pessoa que fala assim; a gente se irrita, não se sente bem porque não gosta de agressividade. Eu digo para os meus filhos que a gente procura a paz. E agora outros têm a voz 
que agrada. Algumas pessoas falam mansinho e dão muita energia. Várias dizem que conhecem a minha voz porque ela é calma e romântica. E acho que eu sou assim porque eu gosto de tratar bem as pessoas, os amigos, o filho, o ex-marido, esse é o meu jeito. Os mais íntimos, pela minha voz, percebem se estou com algum probleminha, mesmo que eu não queira demonstrar. Eu também percebo se estão com problema ou nervosos. Eu acho que a minha demonstração é na voz. Eu percebo isso na voz das pessoas, na forma de se expressar. Entre as colegas você sente pela voz quando elas estão tristes, muda totalmente. As mulheres com quem converso, eu vejo se estão passando ou não por maior dificuldade, por um período difícil. Então, eu vejo diferença: a voz alegre é mais clara, mais ativa; e a voz triste é para dentro, falta entusiasmo, é pausada. Quando a pessoa está alegre ela sorri, conversa bastante, fala alto, forte e para frente. Eu acho que quando as pessoas estão bem elas têm mais alegria na conversa, de modo que ela se sente mais feliz, com a felicidade sstampada no rosto e na voz. Quando está deprimida, triste, a pessoa parece que tem medo de conversar, fica escondida, se recolhe, conversa pouco. Eu percebo se estão alegres ou tristes pela voz. A pessoa triste ela não é solta, é mais presa, para dentro, a conversa é insegura ou mais agitada, eu acho que está com problema sério. Se está alegre fica diferente, a conversa tem mais alegria, é mais solta. No telefone, algumas pessoas amigas percebem quando algo não está bem, ou quando se está alegre, porque fica com uma voz diferente. A minha nora percebe quando estou triste e diz que a voz está borocoxô, que é a quela vozinha triste. Com algumas pessoas é mais difícil perceber, pessoalmente fica mais 
fácil. Então, eu acho que só conversando entendemos melhor e vemos o que a pessoa é na realidade e que a voz está determinando o que os outros conhecem. A voz declara o que a pessoa está sentindo, a voz é quem manda: é no falar que a gente vê o que a pessoa é.

Discurso 2.E: "Experiência profissional com o assunto"

Há um ano atrás eu fazia parte do coral. Havia ensaios e a professora gostava da minha voz. Não que eu fosse cantora porque em um coral não dá para ouvir a voz individual. Eu faço exercícios e massagem na garganta para não trancar a voz e cuido da alimentação porque eu sei que é bom e obedeço.

A Questão 2 apresentou as seguintes Ancoragens a respeito do Tema:

Discurso Ancoragem 2.A- "Apenas aquele que tem conhecimento formal (maior escolaridade, ou estudo especializado) consegue opinar completamente"

Eu acho que quem estudou pode entender o que a voz revela da pessoa e vai peceber se há alguma coisa diferente, que não está bem, conforme conversar.

Discurso Ancoragem 2.B- "As pessoas agem igual a mim"

Acho que da mesma forma que eu noto nas pessoas questões relacionadas à voz, elas notam em mim. Agem da mesma maneira que eu: quando passam por problemas ficam tristes, conversam pouco e se afastam das pessoas que demonstram maldade no tom de voz. 
A Questão 3 - "E a sua voz? Fale um pouco sobre ela" - derivou sete discursos:

Discurso 3.A: "Características positivas observadas na própria voz"

Eu tenho um tom suave na voz. Fazia parte das sopranos, sustentando com o tom elevado, agudo, o contralto e o tenor. Porém, como meu trabalho é agitado, ficava cansada e deixei de ensaiar. A minha voz é tão forte, que quando cantei na Igreja da comunidade, o padre segurou os óculos (para as lentes não se quebrarem) e minha amiga, que estava dormindo, acordou. Eu gosto de conversar com todo mundo, porque se estou me sentindo bem, falo coisas bonitas. Desse modo, eu adoro a minha voz, porém, não sei o que as pessoas pensam a respeito deia, ou se agrada alguém, mas eu acho que gostam, porque é suave. Contudo, às vezes, reclamam que a voz é forte. Assim, eu gosto, acho bonita, bem, porque não é rouca, e creio que ela seja boa porque eu consigo falar direito. Ela sempre foi assim normal, desde criança me criei assim e até hoje estou vivendo. Enfim, é um pouco dificil definir a minha voz, porque, dependendo da maneira como eu falo, ela pode se tornar irritanṫe até para mim, como quando se grita. Existem várias maneiras de se faiar e tenho aprendido que, se for de forma branda, com amor, as pessoas e eu ganhamos muito mais.

Discurso 3.B: "Características negativas notadas na própria voz"

Antigamente, eu soltava mais a voz, era mais fácil, mais limpa. Atualmente minha voz mudou, ficou mais grossa, perdeu a suavidade, 
tanto para falar, quanto para cantar, ficou rouca, mais presa, trancada, não é uma coisa perfeita, mostra um pouco de dificuldade, que notei de uns anos para cá. Eu queria cantar, mas não tenho os agudos, ficou ruim demais para cantar. É uma voz que saì lá de dentro, não posso explicar, é uma voz apertada, não é gritada nem fina, é meio grossa, foi engrossando, é forçada, feia, e eu não gosto, parece voz de homem. Deve ser horrivel ouvi-la, ou pode até ser melhor do que eu penso. Dizem que eu falo muito intenso, mas hoje estou com a voz deprimida, forçada, não está bem. Contudo, também não gosto quando ela fica muito aguda, ardida, engraçada, irreconhecível para mim, estalada, um pouco rápida demais, parecendo uma matraca.

Discurso 3.C: "Condição e estado de observação da voz"

Conforme o estado, a gente tem uma certa postura, elevando a voz. Assim, pode aparecer suavidade ou agressividade e, se eu estiver agitada, fico com a voz fraca e todos em casa percebem. Além disso, a minha voz é um pouco fina e vagarosa para conversar ao telefone.

Discurso 3.D: "Funções exercidas pela voz"

Eu pretendo voltar a ensaiar e cantar no coral porque é gratificante passar a mensagem do evangelho. Isso aumenta a sua fé. À̀s vezes, faz muito bem e as pessoas param para elogiar e incentivar, embora tenha saido no telejornal como coral da terceira idade. Então, eu creio que com a minha voz, a minha fala, eu posso demonstrar amor pelas pessoas, aconselhar ou falar o que elas necessitam ouvir por estarem 
passando por algum problema. Posso até tirar uma pessoa do fundo de um buraco, e trazê-la de volta à vida. É possível agradar às pessoas ou fingir para alguém com a voz. A minha voz é sempre assim, toda vida; eu gosto de ser alegre, conversar, dar risada e de dançar, mesmo que seja escondida do marido. Minha voz não mudou porque eu gosto de contar piadas, estórias, de rir, e nenhuma amiga minha falou que a voz estava diferente. Conforme o seu estado, pode aparecer agressividade ou suavidade na sua voz. Isso acontece com todos, quando se altera, muda o tom de voz, mesmo que não queira. Às vezes, as pessoas são agressivas e conforme você conversa com elas, já nota isso e decide se deve conviver ou não. Eu me afasto, sempre fiz assim. E quando as coisas estão problemáticas, precisa-se de mais sensibilidade, mais suavidade, aprendendo a ser menos amargo, irritado e agressivo. 0 amor, o carinho, a atenção que dedicamos a alguém pode ser a melhor terapia. E esses sentimentos transparecem na voz: se você está feliz, a voz está cantandor ãgora, na situação inversa evitamos fazer barulho, conversamos em baixa intensidade, ouvimos música sossegada, com pouco volume. A minha voz mostra se sou para dentro, bastante fechada, e se estou nervosa, conforme a pessoa com quem converso. Se fico com medo de estar ralando bobagens, a voz modifica um pouco. Se eu estiver bem nervosa a minha voz modifica e eu falo forte ou fraco demais. Aqui eu me senti segura, conversei bem, porém se me tratam com gritos, eu grito também, que é para me defender ou impor respeito, nem sempre conseguido. Quando estou triste, meio deprimida, com probiemas, por mais que eu sinta vontade de mostrar alegria, a voz demonstra a depressão, fica 
apertada, fraca e os mais intimos adivinham, deduzem minha tristeza só pela voz. Se estou alegre, estou bem, aí a voz muda e fica mais agitada.

Discurso 3.E: "Fatores referidos de interferência na qualidade vocal"

Tudo na gente muda, muda muito e dizem que a menopausa modifica a voz, que ela fica mais grossa, como de homem. Os sentimentos e sensações podem afetar a voz, contudo, as tireoideopatias também deixam a voz mais rouca. Algumas pessoas, durante uma gripe, apresentam a voz tapada e rouca e alguns exercícios para a laringe, também, influenciam.

Discurso 3.F: "Fatores referidos de interferência na vida cotidiana"

A pressão alta, o excesso de peso, a menopausa, problemas de memória e atenção, a idade, problemas de saúde e o cansaço interferem na vida das pessoas. Podem modificar a vida sexual diminuindo o entusiasmo e dificultar as atividades diárias. No entanto, deve-se aprender com as dificuldades e tirar proveito para a vida.

Na Questão 3 a Ancoragem que emerge está a seguir:

Discurso Ancoragem 3.A - "A maioria diz que a menopausa muda a vida da gente"

A maioria das pessoas diz que na menopausa há mudança na voz a de comportamento. Pode ser que eu ainda vá sofrer com os problemas, além da voz engrossada. 
Com a Questão 4 "Fale um pouco sobre a sua voz na menopausa", são formados quatro discursos:

Discurso 4.A: "Houve mudanças na voz"

Se há alguma coisa que muda na pessoa depois da menopausa é a voz; a voz muda bastante, dá para sentir a diferença para cantar e para falar. Fica um pouco diferente de quando era jovem: voz de gente nova é mais elegante, não sei se mais fina ou mais grossa. Agora ficou uma voz mais envelhecida, que vai engrossando, às vezes rouca, às vezes não, porém mais travada, trancada. Sinto que tenho que forçar para falar, pois o tom está mais baixo, mais rouco, parece mais fanhosa, dá a impressão de mais fechada. Não sei se é devido ao cansaço físico ou da voz, à ardência e secura da laringe, ou pigarro, mas não é mais feminina. Eu não tinha isso antes da menopausa, por isso acho que modificou, pois era mais fina e agora às vezes a gente sente mal de conversar; parece que se conversa demais fica mais rouca, ou estou com mais facilidade de ficar rouca. Então, eu conversava mais, mas agora prefiro ficar calada. No entanto, para alguns, a mudança não é para pior.

Discurso 4.B: "Não houve modificações na voz"

Eu não senti diferença da minha voz de antes da menopausa para agora. Acho que continua a mesma coisa; não percebi se realmente houve algo porque já estava com problema de voz, então acho que não teve modificação. Portanto, na voz não, na voz não senti mudança nem para cantar, ela sempre foi assim. 
Discurso 4.C: "Ponderações constituídas sobre a própria voz"

Voz feminina é aguda e fina. A voz engrossada da menopausa, ou do cigarro, parece de homem, principalmente no telefone. Ela incomoda tanto por esta confusão quanto por não poder cantar mais em casa ou na Igreja - para quem conseguia, não era desafinada - e por representar que é uma pessoa esquisita, muito feia. As mudanças na voz podem ser produzidas pelo calorão que exacerba o nervoso, pela ansiedade e pela solidão daquelas que moram sozinhas. Aparentemente se vai ficando velha e a voz fica diferente, algo acontece, porque se há emoção ou uso freqüente da voz, aparece o pigarro, que atrapalha, mas é bem diferente de um calo nas pregas vocais; o tom envelhecido da voz faz as pessoas desconhecidas chamarem a gente de senhora - apesar de que o jeito e os assuntos também serem outros da conversa de um jovem - e as conhecidas passarem a estranhar aquela voz. E acho também que a gente chega em uma idade sabendo dar mais valor às coisas, à vida, a essa sensação é transmitida pela voz.

A menopausa ampliou minha sensibilidade: dores, tontura, fraqueza, cansaço físico e da voz, choradeira, depressão, e aumentou o peso corporal que parece só diminuir com exercícios, independente da quantia de alimentos, a não ser que se passe somente com água, trabalhando de oito a dezesseis horas por dia. Algumas informações que recebi sobre sintomas da menopausa, inclusive sobre voz, se concretizaram, outras não. Existem tratamentos com hormônios, até em adesivo para não prejudicar o fígado de quem toma outros remédios, mas os medicamentos também podem trazer mudanças como aumento de 
pêlos, voz de homem perpetuamente. Talvez tenha algum que faça a gente sentir-se melhor, incluindo a voz, apesar de eu não estar doente, porque trabalhar como eu trabalho nenhum doente consegue. E se tem como cuidar da voz grossa é melhor tratar, porque incomoda, pois mesmo falando baixo, igual a todos da família, tem hora que precisa forçar, principalmente se estiver deprimida. A falta de treino (ensaios, exercicios ou cuidados) para cantar, ou problemas de garganta podem prejudicar a voz. Às vezes, o que me incomoda não é a voz, mas os ruidos produzidos durante o sono, o que está sendo pesquisado, pois alteração na tireóide pode provocar isto. As mudanças ocorreram apenas no rosto em que as rugas e a flacidez se instalaram rapidamente ou foram observadas alterações de criança para adulto. Outras alegam sempre falarem calmamente e em baixa intensidade, gostarem da sua voz, ou ainda ter uma voz forte, podendo gritar intensamente com a voz limpa, melhor do que pessoas mais novas.

Discurso 4.D: "Ponderações constituidas sobre a voz dos outros"

Eu leio revistas, escuto reportagens, vi minha mãe e outras pessoas mais velhas que cantavam e percebo que a voz vai mudandio. Quando os idosos apertam a garganta para cantar sai uma voz chiada, apertada, fraca, suja, parecendo estar com algo engasgado na garganta. Então, eu sei que isso poderá acontecer comigo e me preparo. Eu tenho uma irmã que, dizem, depois de descer a menstruação ficou rouca para sempre por ter tomado uma chuva. Tenho também uma colega que tomou uma medicação e a sua voz mudou. Ela tinha que fazer depilação no rosto, 
mas hoje não precisa mais, porque a idade vai amortecendo a necessidade.

Na Questão 4 surge a seguinte situação de Ancoragem:

Discurso Ancoragem 4.A : "Menstruada, tomar chuva deixa rouca"

As pessoas que moram na zona rural dizem que não pode tomar chuva estando menstruada. Isso pode deixar rouco para sempre. 


\section{V - DISCUSSÃO}

Eu quase que nada não sei. Mas desconfio de muita coisa.

João Guimarães Rosa (escritor) 


\section{V - Discussão}

Neste capítulo, é apresentada a análise evidenciada por dois momentos: o primeiro permitido pelos dados dos prontuários e de duas questões surgidas durante as entrevistas (Alteração vocal na menopausa e Auto-imagem vocal) que serviram para caracterizar a população, e o segundo, a análise dos conteúdos dos discursos coletivos, a partir dos depoimentos das mulheres.

De acordo com isso, passamos à análise dos dados de caracterização da população.

A faixa de idade foi pré-estabelecida como critério de seleção (amostra por conveniência) sendo a maior idade apresentada no grupo de 59 anos e a menor de 48; média de idade foi de 52.36 anos; a mediana centrou-se aos 52 anos; e a moda em 50 años.

Todas estavam em menopausa há pelo menos 01 ano (critério préestabelecido); 23 de tipo natural, equivalente a $76,66 \%$; e 07 do tipo cirúrgico $23,33 \%$. A média de idade da menopausa foi 47,3 ; a mediana 48 anos e a moda 49 anos.

A profissão/categoria com maior número de mulheres (10) foi a "do lar", equivalente a 33,33\%; 09 domésticas/diaristas, perfazendo 30\%; 04 mulheres comerciantes/comerciárias (13.33\%); 03 cozinheiras (10\%) e 03 costureiras (10\%); 01 auxiliar de serviços gerais (3,33\%). As profissões indicaram a manutenção de práticas clássicas e tradicionais da região, em funções consideradas femininas. Um terço dessas mulheres (do lar) não era remunerada, indicando maior dependência do cônjuge. 
Sem exceção, as atividades laborais das profissões apontadas necessitam de informações educativas, com vistas à prevenção de alterações vocais, que tanto podem ser ocasionadas mais diretamente por maior freqüência de uso da voz, como é o caso das comerciantes/comerciárias (Bárbara, Joana, Cristina e Iolanda), que não se consideram profissionais da voz, porém são consideradas como tal por fonoaudiólogos, como FERREIRA (1995), quanto indiretamente, por comportarem riscos químicos, físicos, ergonômicos e psicossociais (Ministério da Saúde 2001). Dentre as comerciantes/comerciárias, apenas uma atribuiu a inalterabilidade da sua voz na pós-menopausa ao fato de falar sempre em baixa intensidade.

Apesar de serem amadoras, duas mulheres (Morena e Carolina) haviam, anteriormente, participado do coro de suas igrejas, e, embora recebessem informações mínimas, estavam mais sensibilizadas quanto aos cuidados preventivos necessários para saúde vocal.

A escolaridade foi marcadamente alta entre o ensino fundamental incompleto - 20 mulheres, ensino fundamental completo (06) e alfabetizadas funcionais (02), que, somados, completam 28 mulheres equivalentes a 93,32\% com baixa escolaridade; 01 com ensino médio incompleto (3,33\%); e 01 com ensino médio completo (3,33\%). A escolaridade confirmava as escolhas funcionais, mas não garantia exercer uma profissão condizente com o grau de estudos.

Por definição, os hábitos, costumes e estilos de vida são assim considerados pela freqüência de incorporação na vida cotidiana. Atuam de forma positiva ou negativa, em conformidade aos resultados obtidos. Alguns, por sua natureza, repercutem sobre a qualidade da fonaçăo. 
Assim, a mucosa da laringe é atingida pela utilização do tabaco por efeitos diretos como o calor que a resseca e agride; a destruição dos cílios vibráteis do epitélio cilíndrico do trato respiratório, por meio dos agentes tóxicos inalados (SOUZA e FERREIRA 2000); e a reativa descarga de muco, acarretando uma sobrecarga aos refinados mio-movimentos, capazes de intervir na qualidade da voz. Indiretamente, acomete essa região quando seus inúmeros produtos naturais ou químicos inibem a aromatase dos hormônios das supra-renais e da theca ovariana em hormônios femininos nas células adiposas periféricas, virilizando a voz. Também quando desestabiliza as forças de atuação na laringe durante a fonação, pelas lesões ocasionadas nas paredes pulmonares, ou ainda quando desencadeia enfermidades como as alergias de vias aéreas, ou os cânceres de boca, esôfago, laringe, pulmão (SILVA 1990). Os resultados dessa droga, a curto, médio e longo prazo são tão maléficos que a prescrição de medicamentos (incluindo os hormônios), por profissionais de saúde, aos seus usuários, deve ter cuidados redobrados para que não sejam exacerbados os efeitos colaterais, conforme alertam BARRET e col. (1994). As mulheres entrevistadas tabagistas formam um percentual de $23,33 \%$ (07), apresentando um consumo mínimo 03 e no máximo 20 cigarros/dia.

Visto que o álcool, em pequenas doses, atua como um analgésico sobre as mucosas e cerebelo, ele atenua as sensações físicas (SOUZA e FERREIRA 2000). Por ser um potente desinibidor do comportamento, agindo sobre o sistema límbico, dando a ilusão de potência e destemor, estimula a euforia (EDWARDS 1995). Assim, possibilita gestos mentais, físicos e vocais mais amplos, mais intensos, mais desmedidos, associação que pode culminar com momentos de grandes abusos vocais. Em doses maiores, prejudica o controle vocal e articulatório, alterando a 
entonação (PINHO 1997). Sua constância pode causar irritabilidade na laringe, tosse seca e pigarro, disfonias e afonia, facilitando a instalação do câncer, principalmente de pregas vocais, ou, se associado ao potencializador tabaco, de laringe (SCHUCKT 1991; MILAM e KETCHAM 1986). Entre as mulheres entrevistadas, $16,66 \%$ (05) foram consideradas etilistas por critérios somados de regularidade, constância e quantidade.

O peso corporal é classificado mais comumente pelo método de Índice de Massa Corporal (IMC), de acordo com CUDDY e col. (2000), estando vinculado a algumas queixas vocais (ABITBOL e ABITBOL 1998, 1999) pela aptidão das células adiposas em transformar perifericamente os androgênios em estrona. O Índice de Massa Corporal de 14 mulheres encontrava-se entre 21 e 30 (entre a normalidade e a leve obesidade); de de 02 delas era igual ou menor que 20 (abaixo do peso); 02 estavam entre 31 e 40 (obesidade moderada); e 02 era igual ou maior que 41 (grave obesidade); e 10 não sabiam referir peso ou altura, impossibilitando a composição do IMC, equivalendo a 33,33\% desta população

Os benefícios da prática de exercícios físicos, que atua na prevenção, no auxilio às drogas administradas e na recuperação do tratamento não medicamentoso de múltiplas enfermidades que podem afetar a mulher no climatério, são surpreendentes. Seus efeitos cardiovasculares e metabólicos gerais € endócrinos, a manutenção da força muscular, relevante fator de locomoção, a diminuição do sedentarismo, 0 apoio à conservação da função sexual (KALACHE 1998; MANIDI e MICHEL 1998), ou, ainda, o contato social que proporciona a impressão de estar incluso em um determinado grupo, são fatores relevantes de manutenção de um quadro mais estável de saúde e qualidade de vida (KATCH e MCARDLE 1996). Dentre as mulheres entrevistadas 09 realizavam atividade fisica 
regular (30\%). Dessas, a justificativa para a prática de atividade fisica centrou-se em: 06, na hipertensão; 01, na obesidade, 01 na irritabilidade; 01, na depressão.

A terapia de reposição hormonal ou medicação aos sintomas da menopausa eram administradas em 20 mulheres (66,66\%), dentre as quais 13 $(43,33 \%)$ recebiam também outros medicamentos. Em 08 mulheres $(26,66 \%)$ eram administradas medicações não referentes ao climatério. Apenas $02(6,66 \%)$ não eram medicadas, seja por estarem em pesquisa prévia, seja por não apresentarem nenhuma alteração da saúde.

As enfermidades sistêmicas, ou tópicas, são fatores relevantes que podem modificar ou afetar a condição e funcionalidade das estruturas utilizadas para a fonação (SATALOFF 1998) diretamente, ou por indução, à ingesta de medicamentos.

Os medicamentos e drogas empregados, lícitos ou não, a curto ou longo prazo, podem ocasionar reações gástricas, diuréticas, fragilidade capilar, vasodilatação, edema e diminuição da tonicidade muscular das pregas vocais (SOUZA e FERREIRA 2000), além de modificações histológicas irreversíveis na laringe, no caso dos hormônios andrógenos.

Dentre as mulheres da população de estudo, $16(53,33 \%)$ notam alterações vocais após a menopausa, com apenas $05(16,66 \%)$ delas relacionando a uma boa auto-imagem vocal. Das $14(46,66 \%)$ que não referem mudanças, 11 (36,66\% do total de mulheres e $78,57 \%$ desse grupo) relatam uma boa autoimagem vocal.

Portanto, se a auto-imagem vocal, de acordo com BLOCH (2000), pode estar traduzindo a auto-imagem pessoal, é possível que a imagem (alterada ou não) 
que faz da sua própria voz após a menopausa reflita, também, a sua representação das conseqüências sofridas em razão da menopausa.

Analisaremos, a seguir, os conteúdos dos discursos coletivos compostos considerando que cada um salienta uma representação social, formada a partir de um dado momento em uma determinada cultura, com aproximações à hemenêutica-dialética.

Assim, sobre a Questão 1 ("Como está sendo a menopausa para você?"), no discurso 1.A ("A menopausa não é um período tão difícil de ser enfrentado"), as mulheres relataram a existência de poucos elementos sintomáticos desconfortáveis, que incomodavam com menor intensidade e freqüência, mas que não impediam de manter o controle da situação. Portanto, a menopausa é observada como um processo normal de um período da vida, e a medicação, quando utilizada, tem a finalidade de manter o conforto.

Diferentemente no discurso 1.B ("A menopausa é um período difíil de ser enfrentado"), os sintomas relatados são variados e em grande intensidade e freqüência, importunando, inclusive, outras pessoas de convivência. Dessa forma, a menopausa é vivida como um processo de muito sofrimento, uma doença que necessita de tratamento e atendimento profissionalizado, que requer medicação, de maneira alopática ou natural.

Em contraposição, no discurso 1.C ("A menopausa é um período melhor que a fase reprodutiva"), uma minoria, despreocupada por não apresentarem os sintomas citados, aparentava a sensação de bem-estar e de maior liberdade sexual - aqui a menstruação é vista como doença, e a menopausa, a cura. A concepção do ciclo menstrual trazia para elas uma conotação desagradável e vinculada a 
sofrimentos durante o período reprodutivo, e por isso não desejavam que houvesse sangramento nem como efeito dos hormânios de reposição.

Olhando por este prisma, SEVERINO (1995) concebe-o como a reação contra os modelos tradicionais estruturados, deixando transparecer uma quebra sobre os mitos e preconceitos fundados na sexualidade, mais liberada culturalmente. Assim,

a emergência de novos padrões de relacionamento da mulher na modernidade abriu espaços para que aflorem novas modalidades de crises existenciais. Sozinha, pressionada pelas novas responsabilidades e pelos meios de comunicação que a instigam a lutar por sua emancipação, a mulher se põe a reavaliar sua sexualidade e tudo o que a ela se refira (p.17).

Contudo, a mulher pode estar manipulando, de forma não intencional, o sentido de impureza que acompanha o sangue da menstruação. A conotação positiva livra-a do estigma de sujeira e perigo, no entanto, situa o ritual da passagem de criança para adulta no lugar de objeto em desuso.

Embora os discursos 1.A, 1.B e 1.C possam ser divergentes entre si, no discurso 1.D ("A menopausa com tratamento não é nada") mulheres apontam que a menopausa precisa ser tratada. Deste modo, deixa de ser considerada uma circunstância natural, para constituir um período em que sintomas e sinais orgânicos e psicossociais que interferem na vida cotidiana pessoal e social necessitam ser amenizados.

Daí, a busca de uma medicação mágica, que cure os males, sem causar outros (MENEGON 1999). Um remédio próprio para o seu caso, mais que um̃ 
agente quimioterápico, de acordo com LEFÉVRE (1991), com a função maior de reificação da saúde.

O tratamento, às vezes alivia, e outras vezes não cumpre as expectativas, até traz mais problemas. É possível que o conflito gerado pela ambivalência dos efeitos dos medicamentos, em contraposição ao sofrimento do ciclo menstrual, o temor de uma gravidez indesejada, associados à vida pósmoderna, tenha originado novos sentidos para as mulheres que passam a considerar a menopausa como uma fase menos problemática que a reprodutiva. Afinal, a medicação que mitiga o mal-estar interno, limpa, purifica o corpo que não expele mais o sangue, pode ocasionar os temiveis cânceres de útero e mama (símbolos da sexualidade feminina - lugar de reprodução e manutenção da vida dos descendentes, respectivamente). Dessa forma, há uma certa dialética que afirma, vacila e nega na busca de deixar de ser cúmplice do processo que a submete (SEVERINO 1995).

Assim, a menopausa tratada conduziria certas mulheres ao momento de libertação e sapiência, de igualdade de condições às dos homens, como em algumas tribos indígenas do alto Amazonas, regiões da África e da Índia (HELMAN, 1994). Para outras, entretanto, os efeitos colaterais da medicação produzem ameaças inquietantes que conduzem a decisões pouco esclarecidas, respaldadas apenas pela confiança depositada no profissional de saúde. Deste modo, a menopausa passa a ser um 'processo naturalizado' controlado por medicação alopática ou fitoterápica.

O discurso 1.E ("A menopausa apresenta sinais e sintomas biológicos") culmina em representações sociais construidas por informações mais técnicas veiculadas pela mídia e por profissionais de saúde contactados, por experiência 
própria e como resultado de relacionamento com pessoas, mais ou menos íntimas, na convivência cotidiana.

No discurso 1.F ("A menopausa traz também resultados psicossociais) referem interferência na sexualidade e, por conseguinte, no casamento, com a diminuição do desejo e/ou do prazer. A rigor, o envelhecimento biológico e a adaptação psicossocial são desafios diários. A sexualidade é desequilibrada pelo envelhecimento sexual, pelo medo e pelo mito da incapacidade de relacionar-se sexualmente (HALBE 1995). Todavia, para algumas, o conflito pode ser tamanho (talvez pela intensidade dos sintomas ou por ter sido transformado em representante de um momento de adaptação à perda de um ente íntimo), que passa a ser um 'castigo' às 'coisas erradas cometidas na vida'.

Assim, se tomarmos uma grande parte do mundo ocidental, observamos a predominância da população jovem, com valores e costumes convergentes para essa faixa de idade, preponderando a beleza do corpo, com padrões voltados, psicológica e socialmente, para a juventude, a saúde, a energia física. Em conseqüência, essa fragmentação e reificação do processo saúde leva à sua correspondência reversa da doença, velhice, feiúra e morte (SEVERINO 1995).

Entre os discursos 1.E e 1.F, para algumas, as conseqüências são apenas orgânicas e, para uma delas, a preocupação não era propriamente a menopausa, mas o sangramento intenso que apresentava no momento, e que poderia estar indicando anormalidades na saúde. Outra trouxe a concepção de que, pelo fato de cessar a menstruação, o sangue iria para as pernas, ocasionando varizes, e/ou para a cabeça, resultando em cefaléia. Contudo, para a maioria, os efeitos se estendem aos aspectos psíquicos e sociais. Queixam-se energicamente da intensidade e das conseqüências que as perturbações ocasionam. 
Diante disso, HALBE (1995) explica que no relacionamento familiar œorrem mudanças de papéis da mulher com os filhos e o companheiro, e até mesmo com sua família de origem (não sendo raro a coincidência dessa fase com o cuidar dos pais velhos e/ou doentes). As alterações do papel de mãe podem propiciar retomadas de antigos sonhos e desejos, porém qualquer um que não agrade aos demais é taxado como comportamento de menopausa, sinônimo de envelhecimento.

Pode ser, no entanto, um período que culmine com a aposentadoria, requerendo reformulações nos modos de vida; ou o desemprego e a necessidade de uma luta frenética por um lugar no escasso mercado de trabalho. Ou ainda, conforme COSTA (1995), um momento em que se necessita garantir a continuidade da vida sem a aniquilação da esperança, da curiosidade e da vontade de viver.

Esses valores com os quais as mulheres ocidentais se defrontam na fase do climatério, obrigam-nas a uma reavaliação perante a vida, que refletirá em um maior ou menor conformismo, de acordo com as mudanças que estabelecem, $e$, portanto, em consonância ao conflito gerado. Assim, a incompatibilidade desestabiliza atitudes e implica em sofrimento, que transparece nas relações pessoais e sociais (PICCOLO 1998).

Desequilibrios emocionais, principalmente a depressão e a irritabilidade, também, podem ser freqüentes, em especial se essas mulheres depararem-se com conflitos previamente existentes relativos à feminilidade e identidade (HALBE 1995). Dessa forma, a menopausa pode trazer sentimentos contraditórios de "perda de identidade, obscurantismo, morte e fuga [...] que desnorteiam quem ousa sobre elas refletir" (SEVERINO 1995, p.13). 
Portanto, o profissional que ameniza ou afasta os sintomas, estará suportando um lugar de suposto saber, isto é, de sentimentos e reações mobilizados, distorcidos, resultante do estabelecimento da relação com pessoas significativas (HALBE 2000). Diante disso, visto como placebo, é que se apontam os elementos psicológicos envolvidos na relação paciente-profissional da saúde. Assim, é possivel compreender quando se ouve que 'eu achei que se não fosse ela ( $a$ doutora) nem viva eu estava'.

Em compensação, uma das mulheres, com sinais de enfermidade mental moderada, salientou o impacto da medicação ingerida, como crítica aos profissionais de saúde: calmantes que ocasionavam a perda da libido e a utilização dos hormônios que não auxiliaram na melhora desse sintoma. Outra, amenizando a situação, apontou a possibilidade dessa sensação ser, também, em função do cansaço no trabalho ou da perda da juventude do início do casamento.

Surgem críticas em relação às dificuldades para conseguir atendimento na saúde pública - a demora que impede um tratamento adequado. No entanto, salientam o benefício da prevenção ofertada na assistência pública e relatam valer a pena participar, porque, pode trazer a 'felicidade' durante o processo de envelhecimento.

A ancoragem 1.A ("A menopausa não é igual ao que todos dizem") indica como algumas das mulheres sentiram-se surpresas, pois os sintomas foram diferentes de suas expectativas, por não se assemelharem às queixas apresentadas por pessoas com as quais haviam convivido.

$\mathrm{Na}$ ancoragem 1.B ("Todas as mulheres sofrem os sintomas igual a mim") está centrada em concepções de julgamento, a partir de seu próprio olhar. São 'teorias' elaboradas sobre as relações entre a razão e a emoção, entre a 
subjetividade e a objetividade, "são dois polos de um mesmo processo guiados pelas práticas comunicativas de uma sociedade e sua cultura", conforme analisa (JOVCHELOVITCH 1998, p.60)

Assim, a primeira questão suscitou inúmeras afirmações e representações relacionando a menopausa aos aspectos orgânicos, psíquicos e sociais.

Em relação à Questão 2 ("A voz das pessoas revela algo sobre elas, não é verdade? Fale sobre isso"), no discurso 2.A ("Concordam com a afirmação"), mulheres referem-se à voz com a possibilidade de comunicação da identidade, como membro de uma categoria social particular (PITTAM 1994).

Não obstante, no discurso 2.B ("Discordam da afirmação") há surpresa, dúvida, compreensão confusa da questão, ponderação e, por fim, a discordância. Consideram que a voz não desvela a pessoa (talvez porque não tenham notado mudanças na sua voz), porém os olhos revelam, e o fato de estar olhando nos olhos do outro impede de tentar enganar, mentir.

Sem dúvida, a visão é outro potente canal perceptivo. Nesse sentido, é bastante demandada para suprir, por exemplo, uma perda auditiva (SACHS 1990), ou para leitura de sinais faciais e gestos corporais que ocorrem na linguagem cotidiana.

Também no discurso 2.C ('Considera-se sem conhecimento no assunto") surge a surpresa, a confusão para compreender o questionamento. Há fuga da resposta e ausência de argumentação que culmina com a constatação de desconhecimento sobre o assunto. Por conseguinte, a lógica do pensamento sugerida pela ancoragem A ("Apenas aquele que tem conhecimento formai - maior escolaridade, ou estudo especializado - consegue opinar completamente"), 
complementa o sentido: se existe a questão, apenas quem possui estudo formal, específico a respeito, ou estudo geral, tem a possibilidade de observar e trazer respostas.

Diante disso, THIOLLENT (2000, p. 67) elucida que a relação entre "o saber formal dos especialistas (dotado de certa capacidade de abstração) e o saber informal, baseado na experiência concreta dos participantes comuns" pode gerar dificuldades de compreensão mútua.

Segundo ADORNO e col. (1987, p.408), "o 'poder dizer sobre' está próximo do 'prescrever para', e este poder assume o caráter de controle sobre a relação" estabelecendo regras e hierarquias. Assim, em nossa sociedade, no cenário cotidiano, nas relações entre pessoas e instituições, é bastante aceito pelo senso comum a vinculação entre saber algo e o poder.

Entre os discursos 2.D ("Experiência leiga com o assunto") e 2.E ("Experiência profissional com o assunto") mulheres apresentaram argumentos e experiências de vida para explicitar como a voz revela a pessoa, com diferenças muito sutis entre eles: no discurso 2.E surgiu uma classificação hierarquizada da voz cantada, e uma primeira tentativa de estabelecer situações de prevenção para saúde vocal; no discurso 2.D utilizaram termos técnicos como tom, forte (de grande intensidade), e termos leigos como voz para frente (bem projetada), solta (fluente), alta/baixa (forte/fraca).

A rigor, a voz foi classificada clara, pausada, alegre, triste, nervosa, ativa, borocoxô, diferente, estranha, que agrada, de quem está se sentindo bem/mal. 
Apontaram mudanças notadas na intensidade, na tonalidade, velocidade e ritmo da voz e, algumas, demonstraram como era a voz citada e como ficou após a alteração.

Além disso, distinguiram relações de valoração que a voz instiga, como a pessoa ser boa/má, o grau de vulnerabilidade e de agressividade.

Salientaram a relação de poder, concebendo a submissão e o mando. Determinaram a exclusão do domínio de sua convivência à voz agressiva ou muito intensa, fatores que podem ser percebidos, inclusive, por telefone.

Assim, também, referiram que a voz manda, demonstra o que se sente e determina o que se quer que o outro pense a respeito da pessoa. Os estados de emoção e sentimento modificam a maneira de falar e a tonalidade da voz, ou impedem a sua expressão, quando exacerbados.

Sob essa mesma perspectiva, BEHLAU e ZIEMER (1988), PITTAM (1994), LE HUCHE e ALLALI (1999) e BLOCH (2000) observaram alguns atributos culturais e psicológicos de emissão da voz, relacionando os parâmetros com a caracterização da qualidade vocal e apontando estados, sentimentos e sensações que podem ser revelados por características da voz, empregadas habitualmente nos discursos cotidianos. Evidenciaram a influência da dinâmica emocional, da religião, da "forma de estar no mundo" de um povo, do tipo e modo de relacionamento entre as pessoas, da percepção de dimensão do espaço do outro, da intenção do discurso, das relações de gênero e sexuais, das escolhas valorativas de uma sociedade, do clima regional.

Esses autores denotaram ainda que as interferências podem ser percebidas por intermédio da observação da respiração, da altura, extensão, modulação e intensidade vocal, da freqüência fundamental, dos registros e 
ressonância vocais, do ritmo, velocidade, precisão e acurácia da articulação. Dessa forma, as características vocais individuais perceptivas irão refletir indícios de ritmo de vida, energia, sensação/sentimento de ansiedade, excitação, reação de defesa, persistência, proteção, autoritarismo, dependência, insegurança, imaturidade, raiva, agressividade, preocupação, facilidade de expressar emoções, alegria, festividade, tristeza, melancolia, depressão, tensão, egocentrismo, valores culturais, saúde, fiuência de pensamento, clareza de idéias, grupos etários e profissionais, dentre muitas, podendo conferir credibilidade, organização mental e manifestação de desejo comunicativo, ou gradativamente até o seu inverso.

Mulheres estudadas salientaram a univocidade entre voz e fala, entrelaçando o sentido da palavra com o indício vocal. A esse respeito, PПTAM (1994, p.101) assinala: "na interação os participantes podem usar diversos canais simultaneamente e consecutivamente sem determinar como será transportada a relevante informação", contudo, "no instante final a voz é que carrega a emoção dentro do contexto comunicativo".

Referiram que a voz causa reação no outro, como agitar, incomodar, agradar e irritar. Desse modo, PRETI (1999) e BARROS (1999) evidenciaram os recursos prosódicos na construção dos argumentos ou da persuasão-argumentativa e dos papéis sociais e pessoais na conversação. Assim também URBANO (1999) e MARCUSCHI (1999) relevaram a inerência dos elementos supra-segmentais para a expressividade e sua motivação.

For seu turno, as mulheres entrevistadas, leigas, não-profissionais da voz, discorreram sobre as mesmas questões encontrando apoio em MARCUSCHI (1999), URBANO (1999), BARROS (1999) e PRETI (1999), quando apontaram os elementos prosódicos que, sinalizando o discurso, conduzem à contextualização e 
construção de interesses comuns; ou em MOSES (1954), PITTAM (1994), BLOCH (1999), e LE HUCHE e ALLALI (1999) quando citam as repercussões produzidas, mediante as características assumidas na convivência social e afetiva, esclarecendo as relações, denunciando os estados emocionais e situacionais.

Diante disso, os indicativos apresentados encerraram vinculações sócioculturais, as quais o desconhecimento, ou inobservância, poderá levar a interação ao fracasso naquele contexto comunicativo.

Algumas mulheres, contudo, relataram que olhar nos olhos ou no rosto da pessoa auxilia para o desvendamento dela, e a voz passa ser mais um componente para análise e julgamento. ARENDT (1995) resgata, no simbolismo do mundo sonoro, o movimento corporal, visual e tátil, assumindo que voz e gesto são o que há de mais importante na experiência humana.

$\mathrm{Na}$ ancoragem 2.B ("As pessoas agem igual a $\mathrm{mim}^{\prime \prime}$ ) novamente demonstram uma particular maneira de juízo de valor, para se solidarizarem com o outro.

Com a Questão 3 ("E a sua voz? Fale um pouco sobre ela"), no discurso 3.A ("Características positivas observadas na própria voz") e no discurso 3.B ("Características negativas observadas na própria voz"), novamente, são evidenciados termos técnicos (agudos, rouquidão, rouco, voz limpa, clara, forte/fraca/débil) e leigos (falar alto/baixo, brando, voz fina, estalada, ardida, engraçada, presa, estranha, trancada, grossa, ter o dó para cantar).

Surge a valoração - gostar ou não gostar da própria voz, e as vozes graves são apontadas como feias, porque se parecem com voz de homem. Aparentemente, a sexualidade é confrontada quando a voz se agrava. As vozes agudas também não são bonitas porque 'estalam' ao ouvido. 
Dessa forma, tomando como ponto de partida a definição de disfonia, uma 'boa ou bonita voz' pode ser compreendida como o som produzido sem esforço pela laringe humana, que agrada aos ouvidos próprios e do outro e que se harmoniza com aquele que o produz. Assim, o estabelecimento dos padrões vocais são parâmetros que envolvem o psiquismo e as relações humanas, sociais, e, apesar de juízos individualizados, a valoração é, também, mediada por conceitos de pertencimento e inclusão, inerentes à cultura e linguagem dos grupos.

Manifestaram a preocupação com o fato de outro valorar sua voz e ponderaram se percebem a reação positiva ou negativa do interlocutor, indicando o ato comunicacional envolvido com a questão da alteridade. Para PITTAM (1994, p. 158)

Na interação, a voz pode ter muitas funções e um número de caminhos para relacionar os papéis que nós empreendemos: nossas metas, nossas atitudes com outras pessoas; os sentimentos ou emoções sobre diferentes aspectos da interação, nossa identidade, e a fática relação entre falante, ouvinte e todos os aspectos envolvidos em relação ao gerenciamento e monitoramento da interação.

Referiram claramente a sinonímia voz e manifestação verbal, quando consideraram que falar direito fez parte de sua educação, ou quando relataram que dizem coisas bonitas em momentos de bem-estar. A inclusão do elemento voz na linguagem cotidiana evidencia o que JOVCHELOVITCH $(1998$, p. 55) discute como "problema de produção" apontando que "é na análise da produção que as relações entre representação, subjetividade, linguagem, cultura, identidade e atos comunicativos podem ser clarificados". 
Apontaram diferenças e/ou semelhanças da voz em algumas fases da viḍa, em situações emocionais, e entre a voz feminina e masculina.

O discurso 3.C ("Condição e estado para observação da voz") engloba os fatores de estados - emocional, situacional e comportamental - para observação da própria voz e da voz do outro, concordando com PITTAM (1994, p.123), quando estabelece os princípios de funcionamento da expressão vocal na interação social, resumidos como: 1) a voz é um canal de comunicação que compreende comportamentos não-verbais, especificamente vocais; 2) igual a outro canal nãoverbal, a voz pode ser usada em interações sociais para comunicar identidade, emoções, atitudes (e assim por diante) grupais e pessoais; 3) a voz é usada com fala em muitas interações e como subliminar em todas as falas; 4) a voz pode ser descrita usando muitos tipos de parâmetros articulatórios e acústicos usados para a fala.

No discurso 3.D ("Funções exercidas pela voz") mulheres entrevistadas referiram que a voz tem a função de passar mensagens, por intermédio da fala e de estados que transparecem pelo tom utilizado. Desempenha o papel de demonstrar o jeito de ser/modo de viver que, segundo HABERMAS (1993), são as decisões cotidianas permeadas pela cultura corrente: estados, sensações ou sentimentos como alegria, felicidade, agressividade, suavidade, introversão, nervosismo, depressão.

Apresentam a expressão vocal como capaz de gerar juigamentos, reações (agrado, agressividade, defesa, imposição de respeito), e contra-reações (distanciamento ou proximidade, inclusão/exclusão em um determinado grupo ou em vinculação pessoal). 
Observamos, portanto, que pelos significados que as mulheres estudadas atribuem, podemos assumir, além do efeito de sentido, uma relação de intersubjetividade, em uma prática cotidiana permeada de idealizações (conteúdos normativos) orientada para o entendimento, conforme HABERMAS (1993), em que "o conteúdo expresso constitui uma categoria autêntica de significado"(INGRAM 1994, p.63).

Embora o discurso 3.E ("Fatores referidos de interferência na qualidade vocal"), tenha trazido a menopausa, os estados emocionais, as condições de saúde, em especial das estruturas respiratórias e endocrinológicas, como fatores intervenientes na qualidade vocal, relacionaram às mudanças na vida ("Tudo na gente muda, muda muito").

Nessas circunstâncias, tantos são os fatores e motivos capazes de interferir sobre a laringe e a voz, que a suposição de que apenas os efeitos da ausência dos hormônios gonadotróficos, durante e após a menopausa, sejam os elementos mais relevantes para originarem as alterações relatadas, parece prematura. Cada estrutura vinculada à fonação, ou elemento que ocasiona ajustes orgânicos, somados ao processo de saúde psíquica e de habilidades individuais em lidar com a conjunção de vulnerabilidades coincidentes no momento atual e anteriores, no enfrentamento de circunstâncias diárias ou freqüentes, pessoais ou sociais, resultam em tensões que podem culminar com uma sintomatologia vocal particularizada.

Desse modo, se os fatores orgânicos podem transtornar as caracteristicas vocais, assim também os aspectos psíquicos, como capacidade de administração do tempo entre trabalho e lazer, e de enfrentamento de situações de vida ocasionadas por satisfação e realização, ou ainda aquelas conflituosas, de 
estresses, frustrações, expectativas, planos e objetivos de vida. As circunstâncias de relacionamento com outros, de dificuldades econômicas, de sexualidade, além do temperamento e personalidade, são fatores que interagem todo o tempo, no correr dos anos, cotidianamente, proporcionando tensões físicas e psíquicas, capazes de possibilitar interferências orgânicas, e até mesmo, a somatização (ÉPINAY 1988).

Visto que os aspectos sociais também intervêem, a idade, profissão, etnia, gênero, origem e procedência abrangem determinadas vulnerabilidades e tendências que são minuciosamente particulares (BEHLAU e PONTES 1995; LE HUCHE e ALLALI 1999), distinguindo cada um de nós. Contudo, observações recentes sugerem que as alterações etárias podem ser menos notórias, ou mesmo não ocorrerem, em usuários profissionais da voz (HENICK e SATALOFF 2002).

No discurso 3.F ("Fatores referidos de interferência na vida cotidiana") ao se referirem à possibilidade de a menopausa interferir na sexualidade e no casamento, continuadamente, desde a primeira questão, estendendo-se pelas outras de forma clara ou velada, vincularam fortemente as duas situações.

Para GIDDENS (1993), atualmente, a sexualidade é propícia ao surgimento dos variados estilos de vida, funcionando "como aspecto maleável do eu, um ponto de conexão primário entre o corpo, a auto-identidade e as normas sociais" (p.25). A democratização da vida pessoal pode ter um aliado na emancipação sexual, estendendo-se e reorganizando emocionalmente a vida social.

Contudo, para HABERMAS (1993), "o conceito de modernidade não está mais ligado a nenhuma promessa de felicidade" e a emancipação "torna os homens mais independentes, mas não necessária e automaticamente mais felizes".

Pela tradição, a sexualidade e a reprodução estruturam-se uma à outra (GIDDENS 1993, p.220), isto é, a definição dos papéis sexuais está atrelada à 
reprodução. A menopausa quebra essa regra e a lacuna na identidade pode surgir como perda de feminilidade, que é confirmada pelo agravamento da voz, emergindo concepções de velhice incorporadas às doenças e à sua prevenção.

A mulher, após a menopausa, está em um instante de crise e, portanto, de exarcebação, avaliação e emancipação dos processos pessoais, como casamento, sexualidade, amizade, relação entre pais e filhos, entre tantos outros. Concomitantemente, sofre a interferência da difusão dos movimentos sociais, das transformações nas organizações econômicas, e das relações internacionais. Logo, tem a identidade afetada por cada um dos ângulos distintivos que proporcionam o diálogo entre as franjas biológicas, funcionais e emocionais, com os conseqüentes problemas de ordem social.

Dessa forma, em qualquer uma das situações citadas, necessitar-se-á da construção de uma nova identidade sustentada socialmente (HARDY e col. 1995). Assim, "nas sociedades integradas pelo parentesco [...] esta determina a atribuição de papéis e tarefas dentro da economia doméstica e define, também, a natureza do intercâmbio entre diferentes grupos sociais" (INGRAM 1994, p.166).

Para GIDDENS (1996), "a identidade de uma pessoa necessita, em grande parte, ser descoberta, construída, sustentada ativamente" (p.97), pois as principais mudanças, influenciadas pela globalização, ocorrem na "urdidura da vida cotidiana" (p.97), sendo reordenadas de maneira reflexiva e contínua sobre "as condições das ações de cada um" (p.101). As profundas mudanças sociais, as quais denominou "modernização reflexiva", provocam reações diferentes em cada indivíduo, conforme a capacidade de sofrer o "impacto da globalização, as mudanças que ocorrem na vida cotidiana e pessoal, e o surgimento de uma sociedade pós-tradicional" (p.95). 
Assim, também, para SANTOS (1997), a construção social da identidade e da transformação na pós-modernidade ocidental passa por "um processo de profunda desestabilização que se figura irreversivel" (p. 111) e que torna vulnerável as formas de subjetividade e de sociabilidade.

Enquanto esses dois autores identificam e enfatizam a tradição como um dos pontos de apoio da noção de identidade, HALL (1999) ilumina um sujeito pós-moderno com uma identidade móvel, transformado continuamente, fragmentado, "composto de várias identidades, algumas vezes contraditórias ou não resolvidas (p.10) [...] resultado de mudanças estruturais e institucionais ${ }^{\prime \prime}(p .12)$ que ocasionam um sistema de significação e representação cultural múltiplo e instável de identidades temporárias.

A ancoragem 3.A ("A maioria diz que a menopausa muda a vida da gente") traduz as situações citadas e, embora, para algumas mulheres, as alterações vocais sejam tomadas no conjunto dos sintomas, de forma que tumultuam espaços da vida cotidiana, para outras tendem a pesar menos que os sintomas do climatério e das doenças que se estabelecem neste período.

Com a questão 4 , os discursos são retomados de concep̧ões discutidas nas questões 1, 2 e 3, como voz ser a representação de estados, sensações e sentimentos ou uma preocupação secundária; menopausa como sinônimo de doença (que deve ser tratada); prevenção por meio de exercícios e cuidados, muitas vezes vendida como mais um objeto da perspectiva saúde e doença; menopausa e sexualidade; voz e sexualidade; voz e velhice; menopausa e velhice, aflorando, aí, uma importante relação - a solidão.

Para as mulheres que não tiveram filhos e viveram para cuidar do marido, com a morte deste - comum, por terem uma expectativa de vida maior que 
dos homens - dificilmente responsabilizam-se por, ou possuem menor chance de refazer uma vida conjugal. Aquelas que estão sem os filhos, ou as que (por inúmeras razões) resolveram morar com eles, queixaram-se de solidão ou de sensação de inutilidade, mesmo que em algumas circunstâncias.

Outra representação emergida é de que a mulher tem que passar por isso, ou seja, é do destino da mulher sofrer durante a vida (com a menstruação, com a gravidez e o parto, com a menopausa, com a velhice, com a solidão...). Caso esses rituais não ocorram, ela não será uma mulher completa (HELMAN 1994).

Os termos técnicos e sociais, incluindo enfermidades da laringe, originaram concepções, reflexões e explicações próprias, bastantes condizentes com todo o saber particular, até então demonstrado. Mudanças surgidas, durante e após a menopausa, são citadas nos discursos dessas mulheres, independentes de conhecimento profissional, mas pelo senso comum, indicando quão forte é a presença do objeto de estudo desta pesquisa na cultura e na vida cotidiana.

O trato vocal e sua funcionalidade adequada, nas interfaces com as situações sociais, psíquicas e orgânicas, exigem condições mínimas de equilíbrio geral, aparentemente abalado nesse período transitório, caracterizado pela instabilidade.

O fato de a voz ter se alterado, ou não, tornou-se menos preponderante à medida que as mulheres explicitaram mudanças que ocorreram em razão de doenças associadas, ou durante toda a vida.

Manifestou-se uma representação, ainda inusitada, na ancoragem 4.A ("Menstruada, tomar chuva deixa rouca"): a mulher menstruada não deve molharse, como a puépera também não, com os mais diversos riscos, desde cefaléia, reumatismo, até a possibilidade de tornar-se "louca", mito e representação social 
que imperava fortemente e que incluía a noção de (falta de) higiene corporal (HELMAN 1994).

A partir de tudo que foi aludido, presume-se que uma mulher entre 5060 anos, imersa na pós-modernidade do mundo ocidental, tenha passado por experiências pessoais e sociais suficientes para movimentar-se, com uma certa eficácia, em seus processos comunicativos intra e interpessoais, refletindo as circunstâncias de crescimento emocional permitido pela reflexão, elaboração e emancipação dos problemas inesperados anteriores, ou advindos do fato de se atingir o início de uma nova fase na vida da mulher (HALBE 1995).

Assim, o "preferir ficar calada" pode indicar sabedoria (saber calar-se quando necessário ou saber ouvir), vergonha da própria voz (que não é mais "feminina") ou desestímulo à comunicação (seja por quais motivos, justificativas ou causas forem), necessitando ser investigado.

Corroborando, HALBE (2000a) assinala como a mulher ainda é discriminada por uma parte da sociedade que continua fazendo questão de manter o tradicionalismo, e de realçar determinadas crenças e mitos remanescentes das forças hegemônicas, que são sopesadas e administradas de jus acordo à capacidade de cada uma para adaptar-se às mudanças.

Embora o panorama feminino mundial esteja sendo alterado, dados obtidos por ADELMAN (2002) ressaltam que, em Curitiba, ainda se luta para manter uma cultura convencional, conservando os valores tradicionais, a desigualdade sexual, com o domínio masculino no casamento, sendo esse o provedor e a autoridade máxima no núcleo familiar. O poder compartilhado predomina apenas para casais em que a mulher trabalha fora, tem mais estudos e melhores condições econômicas. 
Para uma sociedade tradicional, patriarcal e cristã, a menarca e o ciclo menstrual são símbolos da reprodução que organiza o parentesco, tornando-se meio de transcendência. A mulher com a possibilidade de procriação é, portanto, desejada e desejante, com uma vida sexual ativa.

Nos discursos das mulheres investigadas poderiamos dizer que a saúde está fundamentada na capacidade do sangue (ausência ou presença) de estabelecer uma identidade feminina, e da medicação para restabelecer a ordem dos cosmos (MENEGON 1999).

A ausência do sangue fica, então, vinculada à perda da identidade e sexualidade, à falta de saúde (guarda as impurezas do corpo) e utilidade (não serve mais para procriar). A alteração de voz durante a menopausa, quando ocorre e é percebida, apenas confirma o sentido de perda da feminilidade, pois a voz agravada é o estereótipo do homem para elas, e também da dificuldade de encantar, de envolver, de seduzir (como as sereias), pois as tornam feias. Poucas percebem a voz com leve agravamento e um pouco nasalizada como sensual, ou que possa transmitir maior autoridade, segurança e maturidade (MOSES 1954; BEHLAU e ZIEMER 1988).

Há, porém, aquelas que, perdendo o companheiro de toda uma vida de casada, dão sentidos que se vinculam ao conceito de viuvez e de reconstrução dos seus parâmetros e valores, em que a menopausa é recebida como um castigo não merecido para a existência de uma mulher que sofreu e vivenciou todos os simbolismos inerentes à feminilidade.

Saúde e doença, de acordo com MINAYO (1996), estão intrínseca e inquestionavelmente relacionados aos sentidos de vida e morte. Arrisco dizer que todos os processos cíclicos, por sua concepção teleológica, também apresentam 
este aspecto. A menopausa, de uma certa forma, constituiria o último estágio de vida de uma mulher: é a entrada para um grupo do qual não se retorna - a velhice e o fim. Embora para algumas mulheres, que se sentem extremamente realizadas ou vencidas, isto faça parte do processo natural da vida, para outras, a promessa ou a sensação de imortalidade, ainda acena com certo furor.

Não se pode esquecer, também, que os discursos partiram de um grupo de mulheres que estavam assumindo o tratamento de sintomas da menopausa, e que, portanto, traziam determinados pressupostos exclusivos. Possivelmente, se não fossem participantes de um Programa de Climatério, o estabelecimento das representações estivesse em outra instância.

À vista disso, para HABERMAS (1993), "nós descobrimos quem nós somos porque aprendemos, ao mesmo tempo, a nos ver numa relação com ós outros", e sendo lingüisticamente competentes entramos em consenso por meio do discurso, obrigados a agir comunicativamente.

Daí, o papel de importância fundamental da voz na comunicação e relacionamento humanos, em uma cultura construida na linguagem corriqueira e cotidiana. Nesse sentido, de acordo com PENTEADO (2003)

nos diversos contextos interativos/comunicativos que se estabelecem no seu cotidiano de vida [...] sua voz está ali, presente na mediação afetiva e na intersubjetividade, sofrendo os impactos dos desejos, das intenções, dos interesses, das emoções, das tensões, dos conflitos, das diferenças, dos sentimentos contraditórios e da qualidade das relações dialógicas e vínculos que se constituem (p.62). 
Dessa forma, a expressão vocal estará refletindo, por conseguinte, as transformações sofridas pela nova identidade assumida, diante de um meio paradoxal.

Conforme Ferreira (1999) a voz é conceituada por diferentes modos de abordagem: é tomada como sons emitidos pelo aparelho fonador; é a faculdade de falar, é a manifestação verbal, é a palavra, o clamor público ou a súplica, é o boato; é o direito de falar, opinar, decidir, eleger, ordenar e comandar, advertir, anunciar; uma sugestão íntima; é a forma com que um verbo indica a ação praticada (voz ativa), recebida (voz passiva), ou simultaneamente praticada e recebida (voz reflexa) pelo sujeito da frase; o som resultante da vibração das pregas vocais; é o trecho vocal de uma composição musical, ou as várias alturas em que o tema é desenvolvido nas fugas para piano e órgã̃.

Ora, aparentemente, os sentidos atribuídos à voz pelo grupo estudado de mulheres, em sua maioria com baixa escolaridade, não deixaram nada a dever às pesquisas dos investigadorés.

A univocidade do sentido imputado à voz e fala, determinado pelos discursos das mulheres, é correspondente ao liame intrínseco que vai se desenvolvendo na aquisição do código lingüístico, cujo valor, para o adulto, é mais ressaltado, enquanto que os elementos lingüisticos supra-segmentais formam o cenário de apoio. A visão integralizadora dessas representações remete à posição de JOVCHELOVITCH (1998, p.59) em que discorre sobre a linguagem como emergência da subjetividade, "a linguagem é fundamentalmente representação - o desejo da linguagem é representar, e na relação entre linguagem e fala nós encontraremos as categorias centrais de um sistema representacional". 
Afinal, quando se estuda a voz, compreende-se, de acordo com PEDROSO (2000), "o equilibrio entre razão e sensibilidade, ciência e arte, corpo e mente" (p.19).

Em compensação, grande parte dos fonoaudiólogos recorta a conotação técnica e especializada, apossando-se dos órgãos produtores dos sons e das suas funções. Como herança da Medicina, afasta as outras possibilidades históricas e culturais de uso do conceito de voz pelo senso comum, fragmentando o sujeito, durante quaisquer dos processos interventivos: de prevenção, avaliação ou tratamento. Em geral, o olhar e pressupostos da promoção de saúde ainda trazem a relação com as ciências médicas e não com as ações educativas.

É possivel que a Fonoaudiologia, de modo geral, saindo da sua posição elitista, viesse a aprender ao realizar estudos a respeito de assuntos da sua área científica, partindo do senso comum, sobretudo para atuar na Saúde Pública. Assim, "as relações [...] podem estabelecer-se nos dois sentidos, sem uma dependência em sentido único, mas com vaivéns entre o pensamento erudito e o pensamento de senso comum", conforme HERZLICH (1991, p.30), quando discute o fenômeno deença.

Dessa forma, a investigação de mulheres sob uma perspectiva dè gênero, poderia conduzir a achados inusitados, como a consideração efetuada por RAMECK (2001).

A cantora Rita Lee, em entrevista concedida a ALBUQUERQUE e COSTA (2001), designa a menopausa ("menopower") como uma iniciação feminina das mais poderosas, como um tempo de reflexão para decidir o próprio envelhecimento: perua fútil em busca da fonte da juventude, ou feiticeira sábia, com o objetivo de autoconhecimento. 
Também, JABOR (2002), argumenta que em um mundo destroçado pelos homens, talvez somente as mulheres feiticeiras consigam responder e salvar a humanidade: "A visão das mulheres poderá ser mais democrática, mais tolerante, mais sutil, nesta época tão dura de transição para uma democracia social", pois trazem reflexões "repassadas de uma subjetividade emocionada de onde sai um pensamento não-fálico, não definitivọ".

Fundamentada nos resultados do último censo do IBGE, SIMONETTI (2000), na revista VEJA, exibiu uma reportagem especial apontando as mudanças sociais conseguidas e sofridas pelas mulheres na última década. Direitos qué geraram deveres e responsabilidades encaradas frontalmente. Desfila mulheres que venceram no mercado de trabalho ou despontaram em suas profissões, convencionalmente femininas, ou não, e das mais de 60 fotografadas e entrevistadas, 46 estão com 40 anos ou mais. Críticas e polêmicas à parte (pois as heroínas que sustentam a família com o salário mínimo, ou aquelas que deixam tudo para dedicarem-se ao apoio e cuidados dos mais desprotegidos, ou para estudar, revertendo o conhecimento em ganhos para o país, entre outros casos, novamente foram mantidas no anonimato), a reportagem ressalta em tom otimista que as características femininas, mal vistas em épocas recentes, tornaram-se qualidades mais valorizadas e até solicitadas profissionalmente na resolução dos problemas atuais. A situação coloca a mulher na vanguarda do poder, alçando-a, em pé de igualdades ou até com vantagens, para uma competição com os homens, como nunca percebida anteriormente no Brasil. Aparentemente, mais um paradoxo neste país de desigualdades. 


\section{VI - CONSIDERAÇÕES FINAIS}

Então escrever é um modo de quem tem a palavra como isca: a palavra pescando o que não é palavra. Quando essa não-palavra - a entrelinha - morde a isca, alguma coisa se escreveu. Uma vez que se pescou a entrelinha poder-se-ia com alívio jogar a palavra fora. Mas aí cessa a analogia: a nãopalavra, ao morder a isca, incorporou-a.

Clarice Lispector 


\section{VI - CONSIDERAÇÕES FINAIS}

Em síntese, os 27 discursos coletivos ou categorias empíricas obtidas das 30 entrevistas realizadas, denotam que as mulheres relacionaram a voz e a menopausa às características biológicas, psicológicas e aspectos sociais do cotidiano.

Nos discursos coletivos da população estudada, ao discorrer sobre a menopausa, mais precisamente sobre a facilidade ou dificuldade de enfrentamento desse período, deparamo-nos com representações, cujos sentidos descortinaram situações extremamente subjetivas, e até íntimas, de posicionamento pessoal perante o mundo.

Os discursos referentes à voz surgiram mesclados por conhecimentos técnicos e do senso comum, e, principalmente, envolvidos por um olhar abrangente, conjuntural, propondo sentidos completos, sociais e coletivos.

Deste modo, foi possivel observar que mulheres do estudo, mesmo não sendo cantoras, divas clássicas ou contemporâneas, nem profissionais da comunicação, que dependem da fonação como instrumento ocupacional, em sua maioria, atribuíram sentidos à voz, salientando suas propriedades de forma clara, em profundidade.

Em conveniência à função comunicativa, no imaginário dessas mulheres, a expressão vocal traz recursos para o conhecimento do outro, estabelecendo o tipo de relacionamento, determinando os papéis assumidos pelos atores sociais. Intermediada pela função estética, a voz humana transmitiria mensagens capazes de beneficiar o outro e a si, gerando estesia e trazendo 
plenitude de sentimentos, enquanto a função subjetiva traduziria estados, sensações e sentimentos, apoiada na expressão de uma cultura.

No que concerne à vinculação existente entre a menopausa e o processo de fonação, as representações transpuseram a mera relação entre idade e característica vocal. Mulheres da população estudada notaram transformações sutis, significando estes movimentos de maneira que ultrapassassem as condições das estruturas orgânicas, indicando períodos, situações e estados psiquicos críticos, para as mudanças vocais e alterações proporcionadas pela menopausa.

Dessa forma, as representações coletivas que emergiram, iluminaram a possibilidade de compreender a natureza comunicacional, ressaltando o objeto de estudo como constitutivo da nova identidade pessoal, concebida na pertinência social.

Ao mesmo tempo, a deflagração dos critérios de análise social privilegiou o aprofundamento da significação de alteridade, oportunizando colocarse sob o ponto de vista do outro, além de auto-conhecimento e auto-reflexão, circunstâncias que conduzem à emancipação.

Analisados sob parâmetros desenvolvidos durante a elaboração da pesquisa, os achados do presente trabalho indicaram a necessidade de outras investigações apoiadas teórico-metodologicamente nas Ciências Sociais, com o objetivo de conhecer e agir sobre os fenômenos fundamentais da relação comunicacional humana. Pela abrangência da abordagem, isto quer dizer que se trata de uma empreitada interdisciplinar, tencionando uma compreensão mais integral e integrada da voz da mulher na menopausa.

Simultaneamente, necessárias, também, a realização de investigações epidemiológicas analíticas, prospectivas e longitudinais, para melhor conhecimento 
da problemática, em padrão populacional. O propósito seria de esclarecimento de hipóteses etiológicas, atingindo fatores causais passados e atuais, utilizando medidas vocais computadorizadas para visualização transversal das condições estruturais e funcionais, e para estabelecimento de critérios individuais e coletivos.

Contudo, esses mesmos achados, solicitam e propiciam a implantação de ações que, somadas às intervenções técnicas de prevenção, em seus vários níveis, ofertem condições sociais de diálogo e vivência com mulheres em sua cotidianeidade, tendo em vista apreender os vários aspectos que influenciam e interferem na qualidade vocal. A proposta conduziria mulheres à reflexão e emancipação, auxiliando a prepararem-se para assumir seu(s) papel(papéis) na sociedade pós-moderna, inseridas no panorama dos contextos atuais de ação, exigentes de definição e remodelação sucessivas.

Ademais, conduziu à necessidade de se ponderar sobre um processo terapêutico vocal preciso e definido, próprio para ser empregado em uma laringe mais vulnerável e alterada, condições que requerem orientação e apoio técnico especifico, priorizando, no entanto, uma proposta de assistência integral à mulher no climatério, com enfoque sobre a saúde da voz.

A ênfase na quantificação por medidas acústicas computadorizadas, exige conhecimentos atualizados da física acústica e da informática. No entanto, 0 aperfeiçoamento de técnicas vocais para prevenção de enfermidades $\mathrm{e}$ aprimoramento da expressão vocal ocupacional, implica conhecer mais das ciências humanas e sociais, pois evidencia as condições psicossociais do indivíduo ou do grupo de profissionais a quem se destina, fazendo emergir as funções de comunicação e estética, sobre as quais se atuará. 
Em particular, para o caso da população estudada, a devolutiva pretende levar à discussão a proposta para atuação e pesquisa, sob a perspectiva interprofissional, no atendimento das mulheres do ambulatório de ginecologia, considerando e incentivando a implementação das concepções da Saúde Pública, nas instituições envolvidas.

Para finalizar, compor a urdidura de um tecido que apresentasse em suas tramas a atualização dos conhecimentos da área fonoaudiológica, médica e de investigação, trançando com concepções sociais, foi um imenso e agradável desafio. Adicionado aos movimentos da vivência de uma pesquisa qualitativa e suas implicações durante a preparação, aplicação, descrição e análise, constituiu-se um exercício, uma dança coreográfica mágica e de ampliação de visão do mundo. 


\section{REFERÊNCIAS}

Abtibol J, Abtibol B. Voix et menopause : crepuscule des divas. Contracept Fertil Sex 1998; 26: 649-55.

Abtibol J, Abitbol P, Abitbol B. Sex hormones and the female voice. J Voice 1999; 13:424-46.

Abitbol J. Voice and hormones. [on line] available from <URL: http://www.voicefoundation.org/VFARBITBOLVOICE\&HORM.html [2003 Jun 9]

Abitbol J, Abitbol P, Abitbol B. Premenstrual voice syndrome and phonosurgical complications. The Voice Foundation's 32 nd Annual Symposium Care of the Professional Voice. Jun 4-8 2003, Philadelphia, Pensylvania [on line] available from <URL: http://www.voicefoundation.org/VFARBITBOLVOICE\&HORM.html [2003 Jun 9]

Adelman M. No caminho da igualdade? Relaçōes de gênero e poder no casamento. 2002. [Tese de Doutorado em Ciências Sociais - Universidade Federal do Paraná].

Adorno RCF. Sociologia: um ensaio de introdução ao seu campo e a algumas de suas vertentes. In: Botazzo C e Freitas SFT, editores. Ciências sociais e saúde bucal: questões e perspectivas. São Paulo: UNESP e EDUSC, 1998; p.104-26.

Adorno RCF, Zione F, Lefèvre F, Silva MEL. O conhecimento e o poder: de quem é a palavra - relato de uma experiência de pesquisa participante. Rev Saúde Pública 1987; 21:405-12.

Albuquerque R, Costa V. Menopower. Rev Seasons. 2001; 9:10-4.

Aldrighi JM Balanço risco/benefício da terapêutica de reposição hormonal: direções para o futuro. Rev Soc Cardiol Estado São Paulo. 1996; 6 :734-8.

Aldrighi JM, Pires ALR. Climatério/ TRH - morbidade, contra-indicações, relação custoeficácia. Rev Reprod Climatério 2001; 16 Supl 2:24-30.

Allyn A, Brizel MD. HRT and the voice. 2002 [on line] available from <URL: http://www.natural-hrt.com/artman/publish/article 73.shtml [2003 Jun 9]

Alves-Mazzotti AJ, Gewandesznajder F. O método nas ciências naturais e sociais: pesquisa quantitativa e qualitativa. São Paulo: Guazzelli; 2000. 
Amado JH. Tableau géneral des problemes poséses par laction des hormones sur le developpment du larinx. Ann Otolaryng 1953; :70-117.

Amir $O$, Kishon-Rabin $L$, Muchnik $C$. The effect of oral contraceptives on voice: preliminary observations. J. Voice. 2002; 16:267-73.

Andrade CRF. Conceito de saúde e saúde fonoaudiológica: uma análise dos discursos profissionais da saúde e dos usuários dos serviços de fonoaudiologia. São Paulo, 2001. [Dissertação de Mestrado da Faculdade de Filosofia, Ciências e Letras da Universidade de São Paulo].

Arendt H. Hannah Arendt. Folha de São Paulo 1995 jun 18; cad 2. Barret DH, Anda RF, Escobedo LG, Croft JB, Williamson DF, Marks JS. Trends in oral contraceptive use and cigarette smoking. Behavioral Risk Factor Surveillance System, 1982 and 1988. Arch Fam Med. 1994; 3:438-43.

Barros DLP. Procedimentos e recursos discursivos na conversação. In: Preti D., organizador. Estudos de língua falada: variações e confrontos. São Paulo: Humanitas Publicações FFLCH/USP; 1999. p.47-69.

Bauer C. Reflexões sobre o tempo e a construção da história. São Paulo: Pulsar; 1997.

Behlau M. Voz. In: Anais do Segundo Simpósio de Fonoaudiologia. Faculdades Metodistas Integradas Izabela Hendrix. Belo Horizonte, 1991.

Behlau M, Ziemer R. Psicodinâmica vocal. In: Behlau M e Pontes P. Avaliação e tratamento das disfonias. São Paulo : Lovise; 1995. p.71-88.

Behlau M, Pontes P. Avaliação e tratamento das disfonias. São Paulo: Lovise; 1995.

Behlau M, Pontes P. Disfonias funcionais. In: Costa, Cruz, Oliveira Otorrinolaringologia. Rio de Janeiro: Guanabara-Koogan, 1996, p.444-53.

Beral V., colaboradores da Million Women Study. Breast cancer and hormonereplacement therapy in the Million Women Study. The Lancet. 2003;362: 419-27.

Berberian AP. A normatização da língua nacional: práticas fonoaudiológicas. São Paulo, 1993 [Dissertação de Mestrado em Distúrbios da Comunicação, Pontifícia Universidade Católica].

Bicalho ICS, Marques JMM. A influência na voz dos anticoncepcionais. Anais IX Congresso de Fonoaudiologia. 2001. 
Boone DR, MC Farlaine SC. A voz e a terapia vocal. Porto Alegre: Artes Médicas, 1994.

Bordieu P. O campo científico. São Paulo :Ática; 1983.

Boulet MJ, Oddens BJ. Female voice changes around and after the menopause: an initial investigation. Maturitas. 1996, 23:15-21.

Bloch P. Noções de Foniatria. In: Hungria, H. Otorrinolaringologia. Rio de Janeiro: Guanabara-Koogan, 2000; p.230-52.

Brandi ESM. Educaçäo da voz falada. Rio de Janeiro: Atheneu; 1984.

Camargo Z. Da fonação à articulação - princípios fisiológicos e acústicos. Rev Fonoaudiologia Brasil. 1999; 2:14-19.

Capra F. O ponto de mutação. São Paulo: Cultrix; 1982.

Cardoso MH, Gomes R. Representações sociais e história: referenciais teóricometodológicos para o campo da saúde coletiva. Cad Saúde Pública. 2000; 16:499506.

Cassol M, Behlau M. Análise perceptiva-auditiva e acústica da voz de individuos idosos pré e pós intervenção fonoaudiológica. Rev Fonoaudiologia Brasil. 2000; 4:32-43.

Chernobelsky SI. A study of menses - related changes to the larinx in singers with voice abuse. Folia Phoniatr Logop 2002; 54:2-7.

Colton $\mathrm{RH}$, Casper J. Compreendendo os problemas de voz. Porto Alegre: Artes Médicas; 1996.

Costa RR. Mulher climatérica: ponto de vista do ginecologista. In: Pinotti JA, Halbe HW e Hegg R. Menopausa. São Paulo: Roca, 1995; p. 21-3.

Chun RYS, Dijk E, Furlan CE, Silvério KCA. Voz profissional: grupos de voz na comunidade de Piracicaba. In: Ferreira LP e Costa HO. Voz ativa - falando sobre o profissional da voz. São Paulo: Roca, 2000; p.79-90.

Cuddy P, Fessler T, Pemberton B. Manejo nutricional da perda de peso. In: Way III CW. Segredos em nutrição: respostas necessárias ao dia-a-dia. Porto Alegre: Artes Médicas Sul; 2000; p. 107-13.

Dângelo JG, Fattini CA. Anatomia básica dos sistemas orgânicos com a descrição dos ossos, junturas, músculos, vasos e nervos. São Paulo: Atheneu; 1998. 
Diniz TMRG. O estudo de caso: suas implicações metodológicas na pesquisa em Serviço Social. In: Martinelli ML. Pesquisa qualitativa: um instigante desario. São Paulo: Veras; 1999; p. 41-59.

Durkheim E. The Elementary forms of the religious life. London: Allen \& Unwin; 1957.

Edwards G. O tratamento do alcoolismo. São Paulo: Martins Fontes; 1995.

Épinay ML. Grodeck: a doença como linguagem. Campinas: Papirus; 1988.

Fant G. Acoustic theory of speech production. Paris: Mouton; 1970.

[FEBRASGO] Federação Brasileira de Ginecologia e Obstetrícia. Climatério - manual de orientação. : Fernandes CE, Soares Fo , São Paulo; 1995.

Feijó AV, Estrela F, Scalco MAG. Análise perceptiva e avaliação quantitativa da voz em indivíduos com idade a partir de 65 anos. In: Behlau M. Laringologia e Voz Hoje :Revinter, São Paulo; 1998.

Fernandes CE, Melo NR, Wehba S. Climatério Climaterium. Rev Bras Med 1992; (ediç esp) 49:123-147.

Ferreira $A B H$. Novo Aurélio: o dicionário da língua portuguesa, século XXI. Rio de Janeiro : Nova Fronteira, 1999.

Ferreira LP. Técnicas de impostação e comunicação oral. São Paulo: Loyola; 1977.

Ferreira LP. Temas de Fonoaudiologia. São Paulo: Loyola; 1985/ 1993/ 1998.

Ferreira LP. Trabalhando a voz: vários enfoques em Fonoaudiologia. São Paulo: Summus; 1988.

Ferreira LP. O fonoaudiólogo e a escola. São Paulo: Summus; 1991.

Ferreira LP. Um pouco de nós sobre voz. Carapicuiba: Pró-Fono; 1995.

Ferreira LP. Dissertando sobre voz. Carapicuíba: Pró-Fono; 1998.

Ferreira LP, Costa HO. Voz ativa - falando sobre o profissional da voz. São Paulo: Roca; 2000.

Ferreira $\mathrm{HJ}$, Colafêmina JF, Iannetta O. Investigação audiométrica no climatério. RBM-Ginecol Obstet. 1992; 3:230-4. 
Figueiredo L. Fora do tom. Jornal da Paulista [on line] Disponível em <URL www.unifesp.br/comunicacao/ipta/ed183/pesquisa4.htm [2003 out 15]

Figueiredo $\mathrm{N}^{\circ}$. O início da prática fonoaudiológica na cidade de São Paulo seus determinantes históricos e sociais. São Paulo; 1988 [Dissertação de Mestrado em Distúrbios da Comunicação na Pontifícia Universidade Católica].

Fonseca AM, Hegg R., Guarniere N C, Melo NR, Filassi JR, Salvatore CA. Climatério: aspectos epidemiológicos e clínicos. Rev Bras de ClinTerap1985;14:43.

Freire RM. Fonoaudiologia em Saúde Pública. Rev Saúde Pública 1992; 26:179-184.

Galli LA, Curia JD, Perzzo I. Disfonias por transtornos do ciclo menstrual feminino. Rev Assoc Argentina Logop Foniat Audiol. 1965; 2:74-5.

Gasparina G, Behlau M. Vocal quality description of senile characters in Holywood films. The Voice Foundation's 32 nd Annual Symposium Care of the Professional Voice. Jun 4-8 2003, Philadelphia, Pensylvania [on line] available from <URL: http://www.voicefoundation.org/VFARBITBOLVOICE\&HORM.html [2003 Jun 9]

Gayoto LH. Trabalho de voz no texto. In: Ferreira LP, Costa HO. Voz ativa - falando sobre o profissional da voz. São Paulo: Roca, 2000; p.137-44.

Giddens A. Para além da esquerda e da direita - o futuro da política radical. São Paulo: Universidade Estadual Paulista; 1996.

Giddens A. A transformação da intimidade. São Paulo: UNESP; 1993.

Gielow I. Nova técnica cirúrgica afina voz de transexual masculino. Folha de São Paulo 1996; ago 18; cad 2.

Goldfien A, Monroe SE. Ovários. In: Greenspan FS, Strewler GJ. Endocrinologia Básica \& Clínica. Rio de Janeiro: Guanabara-Koogan, 2000; p.322-59.

Greene $R$, Dalton K. The premenstrual syndrome. Brit. Med. J. 1953; 1: 41-8.

Greene MCL. Distúrbios da voz. São Paulo: Manole; 1980.

Grillo MHMM, Felício CM, Bignelli PMM, Baroni TM. Percepção da qualidade vocal por diferentes grupos de ouvintes. J Bras Fonoaudiologia 2000; 4: 34-40.

Guyton AC. Textbook of medical physiology. $7^{a}$ ed.,:WB Saunders Company; 1986. 
Guyton AC, Hall JE. Fisiologia humana e mecanismos das doenças. Rio de Janeiro: Guanabara-Koogan; 1998.

Gonzales JN. Fonación y alteraciones de la laringe. Buenos Aires: Editorial Médica Panamericana AS; 1981.

Habermas J. The theorie of communicative action. vol one; Boston: Beacon Press; 1984.

Habermas J. Dialética e hermenêutica. Porto Alegre: LPM; 1987.

Habermas J. El discurso filosófico de la modernidad (doce lecciones) Madrid:Taurus Humanidades; 1989.

Habermas J. Passado como futuro. Rio de Janeiro: Tempo Brasileiro; 1993.

Habermas J. Uma conversa sobre questões da teoria política. Novos Estudos. 1997; 47.

Haguette TMF. Metodologias qualitativas na sociologia. Rio de Janeiro: Vozes; 2000.

Hall S. A identidade cultural na pós-modernidade. Rio de Janeiro: DP\&A; 1999.

Haibe AFP. Aspectos emocionais do climatério. In: Pinotti JA, Halbe HW e Hegg R. Menopausa. São Paulo : Roca, 1995; p.25-30.

Halbe AFP. Repercussões emocionais do climatério. In: Halbe HW. Tratado de ginecologia. São Paulo: Roca; 2000a, p.197-04.

Halbe HW. Controle neuroendócrino do ciclo menstrual. In: Halbe HW. Tratado de ginecologia. São Paulo: Roca, 2000b; p.363-94.

Hardy E, Alves G, Osis MJD. Sociologia no climatério. In: Pinotti JA, Halbe HW e Hegg R. Menopausa. São Paulo: Roca, 1995; p. 31-36.

Hegg R, Melo MR, Pinotti M. Síndrome do climatério-conceito, importância e epidemiologia. Rev Bras Méd 1994; 51:327-30.

Helman CG. Cultura, saúde e doença. Porto Alegre: Artes Médicas; 1994.

Henick DH, Sataloff RT. Desenvolvimento vocal e embriologia da laringe. In: Sataloff RT; Gould W]; Spiegel JR. Manual prático de fonocirurgia. Rio de Janeiro: Revinter; 2002, p.123-36. 
Herzlich C. A problemática da representação social e sua utilidade no campo da doença. Physis Rio de Janeiro 1991; 1(2):23-36

Hildernesse LW. Voice diagnosis. Act Physiol Pharmacol Neerl 1956; :5-73.

Hirano M. Morphological structure of the vocal cord as a vibrator and its variations Folia Phoniat. 1974; 26: 89-94.

Hirano M e Bless D. Exame videoestroboscopio da laringe. Porto Alegre:Artes Médicas, 1997; p.207-24.

Hirano M. Vocal mechanisms in singing: laryngological and phoniatric aspects. In: Sataloff. Voice perspectives. San Diego : Singular Publishing Group, Inc., 1998; p.127-145.

Hungria $H$. Anatomia e fisiologia. In: Otorrinolaringologia. Rio de Janeiro: Guanabara - Koogan, 2000 a; p.201-204.

Hungria $H$. Noções de foniatria - a voz humana. In: Otorrinolaringologia Rio de Janeiro: Guanabara - Koogan; 2000b; p.230-52

Ingram D. Habermas e a razão da dialética. Brasília: UnB; 1994.

Iório C. Avaliação dos encaminhamentos realizados por professores do ciclo básico para o serviço de fonaudiologia da unidade básica de saúde de Vila Palmeiras - São Paulo. São Paulo, 1999 [Dissertação de Mestrado da Faculdade de Saúde Pública da Universidade de São Paulo].

Iório RC. Acupuntura em Ginecologia. Assoc Méd Bras Acupuntura. 2001; 31:12.

Jabor A. Mulheres pensam e falam com o corpo. O Estado de São Paulo 2002; mai, 28 , cad. 3.

Jackson-Menaldi MCA. La voz normal. Buenos Aires: Panamericana; 1992.

Jodelet D. As representaçöes sociais. Rio de Janeiro: UERJ, 2001; p.17-44.

Jovchelovitch S. Representações sociais:para uma fenomenologia dos saberes sociais. Psicologia \& Sociedade. 1998; 10:54-68

Kalache A. Prefácio. In: Manidi MJ, Michel JP. Atividade fisica para adultos com mais de 55 anos. São Paulo : Manole; 1998.

Kase NG. Tratamento da mulher em menopausa. In: Glass RH. Ginecologia de onsultório. São Paulo: Manole; 1989, p.215-25. 
Katch FI, McArdle WD. Nutrição, exercício e saúde. Rio de Janeiro: Medsi; 1996.

Kitzing P. Stroboscopy - a pertinent laryngological examination. J Otolaryngol 1985; 14:151-157.

Lagro-Janssen T, Rosser WW, Weel C. Breast cancer and hormone-replacement therapy: up to general practice to pick up the pieces. The Lancet. 2003; 362: 414-15.

Le Huche F e Allali A. A voz : anatomia e fisiologia dos órgãos da voz e da fala. Porto Alegre: Artes Médicas; 1999.

Lefèvre F. O medicamento como mercadoria simbólica. São Paulo: Cortez; 1991.

Lefèvre F, Lefèfre AMC. Discurso do sujeito coletivo passo a passo [on line] São Paulo, 2000 Disponivel em <URL http://www.fsp.usp.br/qualisaude/dscpassoapasso.html

Lefèvre F, Lefèvre AMC, Teixeira JJV. O discurso do sujeito coletivo: uma nova abordagem metodológica em pesquisa qualitativa. Caxias do Sul: EDUCS; 2000.

Leavell HR, Clark EG. Medicina Preventiva. Rio de Janeiro: FENAME; 1976.

Lewis DR. A prática do fonoaudiólogo em serviço de atenção primária à saúde em São Paulo: um estudo de representações sociais. São Paulo, 1996 [Tese de Doutorado na Faculdade de Saúde Pública da Universidade de São Paulo]. Linville SE. The sound of senescence. J Voice 1996; 10:199-200.

Lopes SMB. Cultura, Linguagem e Fonoaudiologia: uma escuta do discurso familiar no contexto da Saúde Pública. São Paulo, 2001 [Dissertação de Mestrado na Faculdade de Saúde Pública da Universidade de São Paulo].

Machado MAMP, Yunes J. A voz das mulheres na pós-menopausa. In: Anais do VII Congresso de Saúde Pública. Santos; 2001

Maia SM. Repensando a Fonoaudiologia. Rev Dist Com São Paulo;1987: EDUC, 2, $3 / 4$.

Maia SM. Fonoaudiologia e Saúde Pública: perspectivas de trabalho nas UBS. VIII Encontro Nacional de Audiologia. Bauru; 1993.

Maia SM. Implicações sociais do trabalho fonoaudiológico na atenção primária à saúde. In: Befi D. Fonoaudiologia na atenção primária. São Paulo : Lovise; 1997.

Magalhães LCT. Análise da voz em mulheres da terceira idade por meio da fonetografia. São Paulo, 1996 [Dissertação de Mestrado da Pontifícia Universidade Católica]. 
Magno LCL. A voz na menopausa. Porto Alegre, 1999 [Monografia de especialização na área de voz no CEFAC].

Manidi MJ, Michel JP. Atividade física para adultos com mais de $\mathbf{5 5}$ anos. São Paulo: Manole; 1998.

Manoel A. Apresentação. In: Daghlian C. Poesia e música. São Paulo:Perspectiva; 1985.

Martinelli ML. Pesquisa qualitativa: um instigante desafio. São Paulo:Veras; 1999.

Masson MLV. É melhor prevenir ou remediar? Um estudo sobre a construção do conceito de prevenção em fonoaudiologia. São Paulo, 1995 [Dissertação de Mestrado em Distúrbios da Comunicação na Pontifícia Universidade Católica].

Marcuschi LA. Atividades de compreensão na interação verbal. In: Preti D. O discurso oral culto. São Paulo: Humanitas Publicações FFLCH/USP, 1999; p.15-45.

MCArthur, JW. The contemporany menopause. Primary Care 1981; 8:141-64.

Mello MLV. A homeopatia como arte. Disponivel [online] www.homeopatiaonline.com/ver_textoh.asp?id=9 ano V, agosto de 2003.

Mendes VLF. Fonoaudiologia nas UBS: a relação com os usuários. São Paulo, 1994 [Dissertação de Mestrado em Distúrbios da Comunicação Pontifícia Universidade Católica].

Menegon VM. Por que jogar conversa fora? Pesquisando no cotidiano. In: Spink MJ Práticas discursivas e produção de sentido no cotidiano: aproximaçōes teóricas e metodológicas. São Paulo: Cortez, 1999; p.215-41.

Milam JR, Ketcham K. Alcoolismo: mitos e realidades. São Paulo: Nobel; 1986.

Minayo MCS. O desafio do conhecimento: pesquisa qualitativa em saúde. São Paulo-Rio de Janeiro: Hucitec - Abrasco; 1994.

Minayo-Gomes C; Thedim-Costa SMF. A construção do campo da saúde do trabalhador: percurso e dilemas. Cad Saúde Públ 1997; 13 Supl 2: 21-32.

Ministério da Previdência e Assistência Social - Secretaria de Assistência Social. Política Nacional do Idoso. Lei $n^{\circ} 8842,24$ de janeiro de 1994, cap. I (Da finalidade), art. $2^{\circ}$.

Ministério da Saúde do Brasil - Representação do Brasil da OPAS/OMS. Doenças relacionadas ao trabalho: manual de procedimentos para os serviços de saúde. Brasília, DF, Brasil; 2001. 
Molina KL, Brasolotto AG, Felix GB, Cristovam LS. Modificação na freqüência fundamental da voz associada a manifestações de tensão pré-menstrual. Rev Fonoaudiologia Brasil 2000; 4:12-7.

Moraes MD. Como a homeopatia vê a doença. www.homeopatiaonline.com/ver_textoh.asp?id=2 ano V, agosto de 2003 .

Moraes MD. O que você deveria saber sobre a homeopatia. www.homeopatiaonline.com/ver textoh.asp?id=4 ano V, agosto de 2003.

Moraes MD. A homeopatia a menopausa - a opção saudável II www.homeopatiaonline.com/ver_textoh.asp.id=6 ano V, agosto de 2003.

Morin E. Os sete saberes necessários à educação do futuro. São Paulo: Cortez; 2000.

Moscovici S. Introduction à la psychologie sociale. Paris: Larousse; 1972.

Moscovici S. La psychanalys, son image et son public. Paris: Presses Universitaires de France; 1976.

Moses P. The voice of neurosis. Nova York: Grune \& Stratton; 1954.

Mueller PB. Voice characteristics of octogenerian and nonagenerian persons. Ear Nose Throat J 1982; 61:204-07.

Müller OB. Anatomia e fisiologia da laringe. cap. 48 In: Costa, Cruz e Oliveira Otorrinolaringologia. Rio de Janeiro: Guanabara - Koogan, 1996; p.423-34.

Nahoun JC, Simões PM. Climatério e senilidade. Femina. 1986; 14:996-8.

Nghi Nv. Sistemas de canais de energia curiosos: Chong Mai/Yin Wei e Du Mai/Yang Qiao Mai. Rev Paulista de Acupuntura. São Paulo, 1996: 2:51-60.

Notelovitz M. The climateric in perspective. Lancaster, England: MTP Press Limited; 1984.

Paes JP. Ovídio: poemas da carne e do exílio. São Paulo: Companhia das Letras, 1997.

Pedroso MIL. Técnicas vocais para profissionais da voz. In: Ferreira LP, Costa HO. Voz ativa: falando sobre o profissional da voz. São Paulo: Roca, 2000; p.119-36.

Penteado RZ, Pereira IMTB. A voz do professor: relações entre trabalho, saúde e qualidade de vida. Rev Bras Saúde Ocupacional. 1996; 25:109-30. 
Penteado RZ. Aspectos de qualidade de vida e de subjetividade na promoção da saúde vocal do professor. São Paulo, 2003 [Tese de Doutorado. Faculdade de Saúde Pública, Universidade de São Paulo]

Perelló J, Miguel JAS. Alteraciones de la voz. Barcelona: Científico-Médica; 1973.

Piccolo F. Assistência de enfermagem à mulher no climatério. Itajaí, 1998 [Dissertação de Mestrado, Assistência de Enfermagem, Universidade Federal de Santa Catarina].

Pinho SMR. Manual de higiene vocal para profissionais da voz. Carapicuíba : Pró-Fono; 1997.

Pinho SMR, Camargo Z. Introdução à análise acústica da voz e da fala. In: Pinho SMR Tópicos em voz. Rio de Janeiro : Guanabara-Koogan, 2001; p.19-44.

Pittam J. Voice in interaction - an interdisciplinary approach. Califónia - USA, : Sage; 1994.

Preti, D. Estudos de língua falada - variações e confrontos. São Paulo: Humanitas Publicações FFLCH/USP, 1999. Tipos de frame e falantes cultos; p.71-86.

Queiroz MS. O itinerário rumo às medicinas alternativas: uma análise em representações sociais de profissionais da saúde. Cad Saúde Pública 2000; 16:36375.

Rameck MF. Dinâmicas da voz e do gênero: uma questão de poder. São Paulo, 2001 [Tese de Doutorado em Lingüistica Aplicada e Estudos da Linguagem. Pontifícia Universidade Católica].

Rothman $H$, Brown WS, Shiravastav R, Hollien $H$. Temporal characteristics between individuals perceived as young adult and aged speakers. The Voice Foundation's 32 nd Annual Symposium Care of the Professional Voice. Jun 4-8 2003, Philadelphia, Pensylvania <URL: http://www.voicefoundation.ora/VFARBITBOLVOICE\&HORM.html [2003 Jun 9]

Russo IP. Acústica e psicoacústica aplicadas à fonoaudiologia. Rio de Janeiro: Lovise; 1993.

Sá CP. Núcleo central das representações sociais. Petrópolis: Vozes; 1996.

Sá MFS, Petracco A. Endocrinologia do climatério. Reprod Climatério. 2001; Supl.II,16:6-10.

Sacks OW. Vendo vozes. Rio de Janeiro: Imago; 1990. 
Samsioe G. The role of ERT/HRT. Best Pract Res Clin Obstet Gynaecol. 2002; 16: 371-81.

Santos BS. Um discurso sobre as ciências. Porto - Portugal: Afrontamento; 1993.

Santos BS. Pela mão de Alice - o social e o político na pós-modernidade. Lisboa: Afrontamento; 1995.

Santos BS. A queda do Angelus Novus - para além da equação moderna entre raízes e opções. Novos Estudos. 1997; 47:103-24.

Sataloff RT, Spiegel JR, Rosen DC. The effects of age on the voice. In: Sataloff RT. Professional voice: the science and art clinical care. San Diego: Singular Publishing Group Inc.; 1997, p. 259-67.

Sataloff RT. Vocal health and pedagogy. San Diego: Singular Publishing Group Inc.; 1997; Clinical anatomy and physiology of voice, p. 5-25.

Sataloff RT. Voice perspectives. San Diego: Singular Publishing Group Inc.; 1998a; The physics of sounds, p. 65-77.

Sataloff RT. Vocal health and pedagogy. San Diego: Singular Publishing Group Inc., 1998b, Common medical diagnoses and treatments in profissional voice users, p.107-21.

Sataloff RT, Emerich KA, Hoover CA. Endocrine Dysfunction. In: Sataloff RT. Voice perspectives. San Diego : Singular Publishing Group Inc.; 1998, p.291-7.

Scalco MAG, Pimentel RM, Pilz W. A saúde vocal do professor: levantamento junto a escolas particulares de Porto Alegre. Prófono Rev de Atualização Cient 1996; 8:25-30.

Schuckit M. Abuso de álcool e drogas - uma orientação clínica ao diagnóstico e tratamento. Porto Alegre: Artes Médicas; 1991.

Schurmann E. A música como linguagem - uma abordagem histórica. São Paulo: Brasiliense/CNPq; 1989.

Seifer DB. Acompanhando o declínio ovariano. Orgyn. 1999; 4:47-50.

Severino FES. Mulher climatérica - ponto de vista da mulher. In: Pinotti JA, Halbe HW, Hegg R. Menopausa. São Paulo: Roca, 1995; p.11-19.

Silva VLC. Tabagismo - um problema de saúde pública no Brasil. JBM. 1990; 59:1423. 
Silva MC, De Biase N. Estudo da freqüência fundamental em mulheres jovens com síndrome pré-menstrual. Rev Dist Comunicação. 2000; 11:301-11.

Simões M, Latorre MRDO, Bitar ML. Uso profissional da voz por educadores de creches. Rev Soc Bras Fonoaudiologia. 2000; 7:28-35.Simonetti EG. Elas venceram. Rev Veja. 2000, : Abril, ed. 1674, ano 33, no 45.

Sória RAB. Nova tecnologia para reconhecer a voz humana. J Voz do Paraná. Curitiba; 2002, 1762.

Souza TMT, Ferreira LP. Um século de cuidados com a voz profissional falada: a contribuição da Fonoaudiologia. In: Ferreira LP e Costa HO Voz ativa: falando sobre o profissional da voz. São Paulo: Roca, 2000; p.1-19.

Spink MJP. Representações sociais:questionando o estado da arte. Psicologia \& Sociedade. 1996; 8:166-186

Tajfel H. Human groups and social categories. Cambridge: Cambridge University Press; 1981.

Tarneaud J. Trité pratique de phonologie et phoniatric. Paris: Maloine; 1961.

Thiollent M. Metodologia da pesquisa-ação. São Paulo: Cortez e Autores Associados; 2000.

Tize IR. Comments on the myoelastic aerodynamic theory of phonation. J Speech Hear. 1980; 23: 492-510.

Titze IR. Segredos de uma voz. Folha de São Paulo. 1995; 29 out, cad. Mais!

Tolosa H. Menopausa: mitos e verdades._ São Paulo : Contexto; 1997.

Trien SF. Menopausa a grande transformação. Rio de Janeiro : Rosa dos Tempos; 1994.

Urbano H. A expressividade na língua falada de pessoas cultas. In: Preti D. 0 discurso oral culto. São Paulo : Humanitas Publicações FFLCH/USP; 1999, p. 131-51.

Vasconcelos AM. Percepções vocais relacionadas às alterações hormonais em mulheres. São Paulo, 2000 [Relatório final de pesquisa de Iniciação Científica (PIBIC - CEPE) da Pontifícia Universidade Católica].

Vieira MEMG, Sá MOSM, Costa ACCS, Parreira AP, Alves EO, Castro M, Oliveira SHS. 50 anos da Fonoaudiologia nos 500 anos de Brasil. Rev Soc Bras Fonoaudiologia 2000; 7:18-21. 
Viola IC, Ferreira LP, Sene CD, Villas Boas DC, Souza SM. A voz do professor: levantamento das publicações brasileiras. Rev Soc Bras Fonoaudiologia. 2000;7:3645

Vygotsky LS. Pensamento e Linguagem. São Paulo : Martins Fontes; 1987. 


\section{ANEXOS}

O ato criador depende de um amor intelectual pelos objetos da experiência.

Einsten (cientista) 


\section{ANEXO I}

FACULDADE DE SAÚDE PÚBLICA DA UNIVERSIDADE DE SÃO PAULO

SANTA CASA DE MISERICÓRDIA DE CURITIBA

AMBULATÓRIO DE GINECOLOGIA - PROGRAMA DA MULHER NO CLIMATÉRIO

\section{ROTEIRO TEMÁTICO}

1) Como está sendo a menopausa para você?

2) A voz das pessoas revela algo sobre elas, não é verdade? Fale sobre isso.

3) E a sua voz? Fale um pouco sobre ela.

4) Fale um pouco sobre a sua voz na menopausa. 


\section{ANEXO II}

\section{INSTRUMENTO DE ANÁLISE DO DISCURSO 1}

\begin{tabular}{|c|c|c|}
\hline \begin{tabular}{|l|} 
EXPRESSÕES - CHAVE Questão1 \\
Como está sendo a menopausa para você?
\end{tabular} & IDÉIAS CENTRAIS & ANCORAGEM \\
\hline 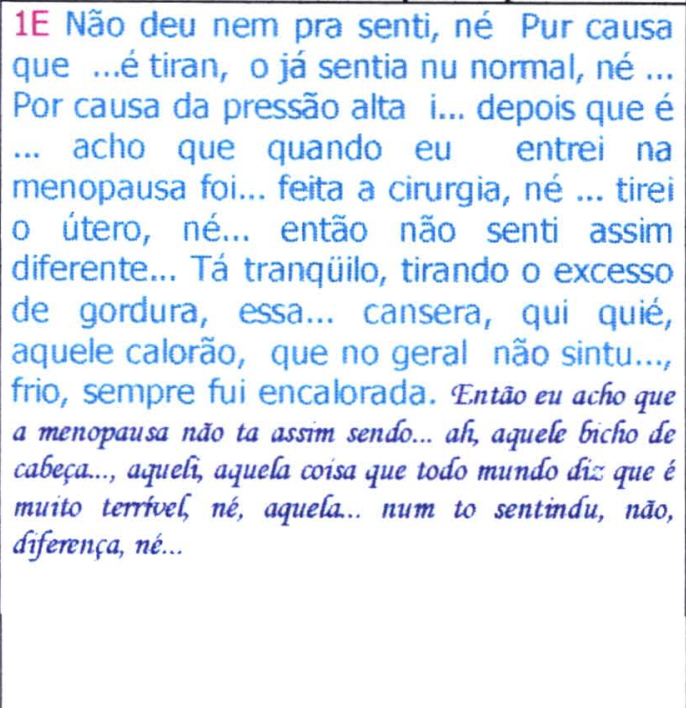 & $\begin{array}{l}\text { (2) Sente muito calor, mas é } \\
\text { por causa da pressão alta, } \\
\text { tem canseira e engordou } \\
\text { depois que entrou na } \\
\text { menopausa cirúrgica. } \\
\text { E }\end{array}$ & $\begin{array}{l}\text { A menopausa } \\
\text { não é igual ao } \\
\text { que todos } \\
\text { dizem. } \\
\text { A }\end{array}$ \\
\hline $\begin{array}{l}\text { 2E Olha, eu acho assim, eu to começando... } \\
\text { aqueles calorões que é o famoso...Ta poco } \\
\text { ainda mais ... já começo, né... I euo ... } \\
\text { resolvi procurą meios, é justamente nem pelo } \\
\text { fato de ... di ja num to tendo mais desejo sexuaf...e eu } \\
\text { sinto prazer mas num tenfo aquela como toda... nu } \\
\text { começo a gente tem, né Então..., ta razoável pur } \\
\text { enquantu tá razoável. Ainda to dando conta } \\
\text { do que sinto. }\end{array}$ & $\begin{array}{l}\text { (1) Está começando um } \\
\text { pouco dos calorões famosos, } \\
\text { de forma razoável, e acha que } \\
\text { dá conta do que sente. } \\
\text { Resolveu buscar meios (para } \\
\text { tratar) } \\
\text { A } \\
\text { (2) Tem prazer sexual, mas } \\
\text { diminuiu muito o desejo. } \\
\text { E }\end{array}$ & $\begin{array}{c}\text { Todas as } \\
\text { mulheres } \\
\text { sofrem os } \\
\text { sintomas igual } \\
\text { a mim. } \\
B\end{array}$ \\
\hline $\begin{array}{l}\text { 3E É horrível, né... Péssima!! Calorão, } \\
\text { né... e daí é horrivel, ... Por issu to } \\
\text { buscando ajuda, sim pra vida toda... }\end{array}$ & $\begin{array}{l}\text { (1) A menopausa é horrível, } \\
\text { terrível. Por isso foi buscar } \\
\text { ajuda e acha que é para a } \\
\text { vida toda. B } \\
\text { (2) Sente muito calorão. E }\end{array}$ & \\
\hline $\begin{array}{l}\text { 4E Agora pra mim eu num... senti aqueles calor, } \\
\text { aquelas coisa qui nem as muther falam, safí? purque } \\
\text { pra mim faiz tempu que termino a ... } \\
\text { menstruação, faiz uns ... oito anu já... } \\
\text { cabo assim dai... Só num consigo usa essas } \\
\text { coisa fechada assim qui nem a blusa... } \\
\text { Nunca consegui... fora isso... eu mi sintu } \\
\text { bem em tudu... }\end{array}$ & $\begin{array}{l}\text { (1) Não sentiu muito calor } \\
\text { como as mulheres falam, mas } \\
\text { não consegue usar blusas } \\
\text { fechadas. E } \\
\text { (2) Fora isso se sente bem. } \\
\text { A }\end{array}$ & $\begin{array}{l}\text { A menopausa } \\
\text { não é igual ao } \\
\text { que todos } \\
\text { dizem. } \\
\text { A }\end{array}$ \\
\hline $\begin{array}{l}\text { 5E A menopausa... eu já tive problema de } \\
\text { calorão, senti falta de ar, mas daí eu }\end{array}$ & $\begin{array}{l}\text { (1) Teve problema de calorão } \\
\text { e falta de ar na menopausa. E }\end{array}$ & \\
\hline
\end{tabular}




\begin{tabular}{|c|c|c|}
\hline $\begin{array}{l}\text { procurei um tratamento agora, né ...é mais } \\
\text { nada... agora eu to me sentindo bem. }\end{array}$ & $\begin{array}{l}\text { (2) Procurou tratamento e } \\
\text { agora se sente bem. D }\end{array}$ & \\
\hline 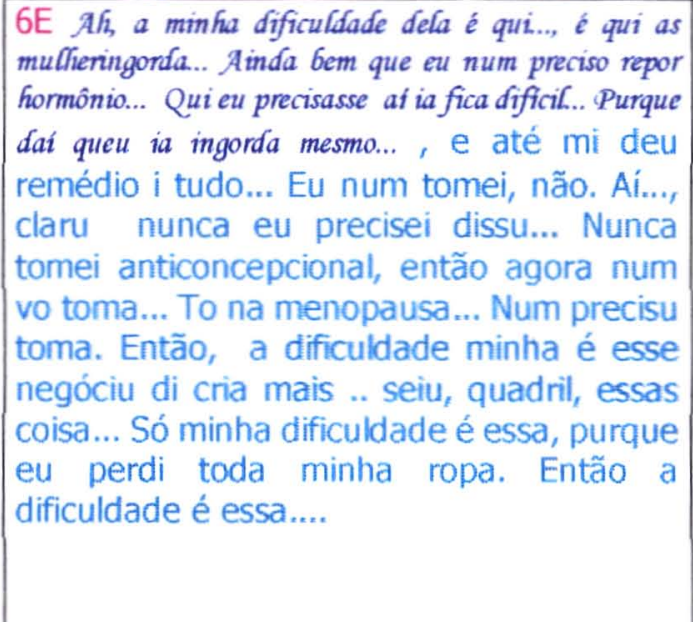 & $\begin{array}{l}\text { (1) Engordou, criou seio, } \\
\text { quadril. E } \\
\text { (2) Apesar de dificil, acha } \\
\text { bom não ter que repor } \\
\text { hormônios para não engordar } \\
\text { mais, pois perdeu todas as } \\
\text { roupas. Fez todos os exames, } \\
\text { estava tudo bem e acha que } \\
\text { como nunca precisou tomar } \\
\text { anticoncepcional também não } \\
\text { precisará de hormônios agora } \\
\text { (na menopausa) } \\
\text { B }\end{array}$ & $\begin{array}{c}\text { Todas as } \\
\text { mulheres } \\
\text { sofrem os } \\
\text { sintomas igual } \\
\text { a mim. } \\
\text { B }\end{array}$ \\
\hline $\begin{array}{l}\text { 7E Olha, menopausa ta sendo um poblema } \\
\text { muuito sério pra mim, eu tenho muuito } \\
\text { calor, eu tenhu qui toma banhu.... duas, } \\
\text { treis vezis, eu me., dipois quieu tive aqui a } \\
\text { primeira vez, quiessa é a.. tercera veiz } \\
\text { quieu estou aqui, eu fiquei bem pior. Minha } \\
\text { pressão não normaliza, as veis ta doze por } \\
\text { nove, assim como sobe e podi infarta... } \\
\text { mas no meu limite mesmo, purque pode } \\
\text { aumenta di cansera... Mi sintu tristi ... } \\
\text { purque a gente num consegui vim aqui... } \\
\text { era pra mim ter vindo aqui em abril, agora } \\
\text { qui o posto conseguiu pra mim volta qui. } \\
\text { Então a gente num consegue faze o } \\
\text { tratamento direitu... }\end{array}$ & $\begin{array}{l}\text { (1) A menopausa é um } \\
\text { problema sério. Fica triste } \\
\text { porque não consegue voltar } \\
\text { com a freqüência necessária } \\
\text { ao médico para fazer direito o } \\
\text { tratamento } \\
\text { B } \\
\text { (2)Sente muito calor tendo } \\
\text { que tomar muitos banhos } \\
\text { durante o dia para aliviar. } \\
\text { Tem problemas de pressão } \\
\text { instável e cansaço, apesar de } \\
\text { estar voltando pela terceira } \\
\text { vez para consulta. } \\
\text { E }\end{array}$ & \\
\hline $\begin{array}{l}\text { 8E Bom, a menopausa pra mim, tá me } \\
\text { danu ua, assim uma tristeza que não sabia } \\
\text { queu ia passar por isso aí queu to passano, } \\
\text { queu nunca tomei comprimido, sim desses } \\
\text { comprimido di evita filho... então eu queu } \\
\text { to sintino assim oh, fatigada, me dá } \\
\text { tristeza... eu fiz, que nem eu, so sozinha, } \\
\text { num tem maridu, num tem relação, num } \\
\text { tem nada, eu to sintino uma coisa bem... } \\
\text { bem triste pra mim. Que é uma coisa eu } \\
\text { pensava queu num ia passa por isso aí. } \\
\text { Purque num so intristida faze muitas coisa } \\
\text { errada, num so de faze e agora i... também } \\
\text { to pensando três anos qui sofri..., então eu } \\
\text { acho que, qui pra mim ta sendo bem dificil, } \\
\text { purque eu moro sozinha... e ta sendo bem } \\
\text { difícil pra mim. Iiiii, isperava queu dasse um }\end{array}$ & $\begin{array}{l}\text { (1) A menopausa está sendo } \\
\text { difícil e sofrido. Nunca tomou } \\
\text { anticoncepcional, nem fez } \\
\text { nada errado e não esperava } \\
\text { isso. Faz três anos que busca } \\
\text { um tratamento e só agora } \\
\text { conseguiu. Está na na } \\
\text { expectativa de cirurgia ou } \\
\text { tratamento medicamentoso. } \\
\text { B }\end{array}$ & \\
\hline
\end{tabular}




\begin{tabular}{|c|c|}
\hline $\begin{array}{l}\text { jeito deu melhora... pra mim sinti a ... mais } \\
\text { pro final assim da, da meia idadi, issu } \\
\text { sintia mais feliz... purque, seu era tão feliz } \\
\text { até agora, agora dispois do poblema de } \\
\text { menopausa me dexo desse jeito aí então... } \\
\text { eu fiquei meio chatiada. Por isso to } \\
\text { buscando tratamento, to buscando já ta } \\
\text { com três ano queu to atrás de faze } \\
\text { tratamento. Mas só que num deu certo de } \\
\text { faze, quando é agora to com cosulta } \\
\text { marcada dêsdo mes de maio, consegui hoje } \\
\text { aqui a cosulta, to desdo meio de maio } \\
\text { cuessa cosulta marcada, então.. agora vô } \\
\text { vê o que o médico vai fala, ... é pra opera } \\
\text { a gente opera, si num é tamém a gente vai } \\
\text { fica, purque... u serviçu... Então, é isso ai } \\
\text { quieu to passano. }\end{array}$ & \begin{tabular}{|l|} 
porque se sente fatigada, e \\
chateada, é sozinha (viúva). É \\
difícil chegar à meia-idade \\
dessa forma infeliz. Gostaria \\
de melhorar para voltar a ser \\
feliz. Não pensava que \\
passaria por tudo isso \\
E
\end{tabular} \\
\hline $\begin{array}{l}\text { 9E Achu qui pra mim ta senu um períodu } \\
\text { assim muituuu, di muito nervosismu... queu } \\
\text { achu qui não é normal... Fica nervosa } \\
\text { assim, as vezes até por nada... então achu } \\
\text { qui num ta certu. Achu qui ta, ta sen" muit" } \\
\text { difícil. Qui as vez a gente qué é dize qui é } \\
\text { algum poblema, mas as veiz é poblema da } \\
\text { gent' mesmu.. Eu achu qui é issu... }\end{array}$ & $\begin{array}{l}\text { (1) A menopausa está sendo } \\
\text { um período difícil } \\
\text { B } \\
\text { (2) Sente } \\
\text { quito nervosismo } \\
\text { não acha } \\
\text { normal certo nem } \\
\end{array}$ \\
\hline $\begin{array}{l}\text { 10E Ah, eu creiu qui ta senu bom pra mim, } \\
\text { purque eu já tenhuuo... quatru anus, eu } \\
\text { estava fazenu a conta, queu num tenhu } \\
\text { mais menstruação, mais a minha vida } \\
\text { continuaa.. igual, tantu na manera di do } \\
\text { meu casamento... se falanu em sexu, vamu } \\
\text { dize, continua sendo igual pra mim, então } \\
\text { eu num tive problemas nessa área... di.. di } \\
\text { qui paroo, a coisa mudoo... pra mim } \\
\text { continua senu a mesma forma, por } \\
\text { exemplo, siii antigament }{ }^{\mathrm{e}} \text { quando se tem } \\
\text { menstruação é difícil... muitas vezes se } \\
\text { tem dores, i eu num tenhu nada, eu mi } \\
\text { sintu super bem. }\end{array}$ & $\begin{array}{l}\text { A menopausa está sendo um } \\
\text { período bom porque faz anos } \\
\text { que não menstrua, época em } \\
\text { que tinha muitas dores. Não } \\
\text { modificou seu casamento nem } \\
\text { o sexo. Está se sentindo super } \\
\text { bem }\end{array}$ \\
\hline $\begin{array}{l}11 E \text { Ah, sab }{ }^{1} \text { que judio bastanti... Eééé, por } \\
\text { causa do calorão... deixa a genti assim.... } \\
\text { pareci ner, pareci aborrecidu... não, num } \\
\text { contu assim quié nervosu, é aborr }{ }^{e} \text {, } \\
\text { aborrecimento dentu da genti.., Mais agorá } \\
\text { já carmo, num ta taaanto mais aqueli } \\
\text { calorão mais... }\end{array}$ & $\begin{array}{l}\text { (1) A menopausa judiou } \\
\text { bastante. B } \\
\text { (2) Agora melhorou (após } \\
\text { TRH). D } \\
\text { (3) O calorão a deixava muito } \\
\text { aborrecida. E }\end{array}$ \\
\hline $\begin{array}{l}\text { 12E pra mim sempri foi tudu bem, porque } \\
\text { a minha menopausia i antis de para eu } \\
\text { fiquei muito calorzâo, tinha muita friçấo... } \\
\text { Mais agor depois qui paro, eu sintu bem, } \\
\text { só num sintu bem pur casu.. muito bem } \\
\text { assim, pur casu tem muita dor di cabeça }\end{array}$ & $\begin{array}{l}\text { (1) Antes de parar a } \\
\text { menstruação tinha muito calor } \\
\text { e aflição. } \\
\text { A } \\
\text { (2) Depois que entrou na }\end{array}$ \\
\hline
\end{tabular}




\begin{tabular}{|c|c|c|}
\hline $\begin{array}{l}\text { ainda, mais eeu, recramu só da pressão } \\
\text { alta... Eu tomu remédiu pra pressão. Não } \\
\text { tomu hormônio pur enquantu não. Pur } \\
\text { enquantu não purque a dotora falo qui tem } \\
\text { qui faze todu tratamento pra toma, né. Aí } \\
\text { ela pidiu us tratamento di modu eu pude } \\
\text { toma. Num tumei nenhum ainda. }\end{array}$ & $\begin{array}{l}\text { menopausa sente-se bem, } \\
\text { Mas precisa tomar remédios } \\
\text { para pressão alta e tem dor } \\
\text { de cabeça. Não toma } \\
\text { hormônios porque está } \\
\text { fazendo exames para saber } \\
\text { dos riscos. } \\
\text { E }\end{array}$ & \\
\hline $\begin{array}{l}\text { 13E Bão, a menopausa é muito calorão... } \\
\text { um pouco di tontura, às vezes me dá um } \\
\text { poquinho di dor di cabeça, mais é bem } \\
\text { poquinho... Iii, eu mi sinto muito mal } \\
\text { tamém di madrugada, percu sono... ii.... } \\
\text { qui mais queu possu dize? É um poco } \\
\text { difícil... um poco purqueee.. purque teim...é } \\
\text { pertuba...i a genti fica assim, dá aquele } \\
\text { suado... I, da vontadi di levanta, das veiz } \\
\text { eu puxo a cuberta, i eu tenho friu eu puxo } \\
\text { a cuberta... dali a poco eu sintu calor, eu } \\
\text { jogu a cuberta... i viru pra lá, i viru pra cá... } \\
\text { Meu maridu fica acomodadu, i fala "Poxa, } \\
\text { mais ce dormi"... I, mais ié eu qui to cu, } \\
\text { cum calorão... cumé qui vo faze... ... eu } \\
\text { tomanu comprimiidu, diminuiu um poco... } \\
\text { Nossa, quandu eu num tomu, ai u negóciu } \\
\text { fica feio mesmu, daí piora... Dá aquele } \\
\text { suado assim.... i as vezi mi dá } \\
\text { embaçamento di vista tamém, quanu ta pra } \\
\text { vim... daí eu ficu com a vista meio } \\
\text { imbaraçada. Assim.. inxergu quelas } \\
\text { luuzinha correnu... }\end{array}$ & $\begin{array}{l}\text { (2) Perturba porque traz } \\
\text { muito calorão, tontura, um } \\
\text { pouquinho de dor de cabeça e } \\
\text { insônia por causa do suador. } \\
\text { Incomoda o marido de tanto } \\
\text { que se movimenta de } \\
\text { madrugada, por causa do } \\
\text { calor e frio que sente. } \\
\text { E }\end{array}$ & \\
\hline 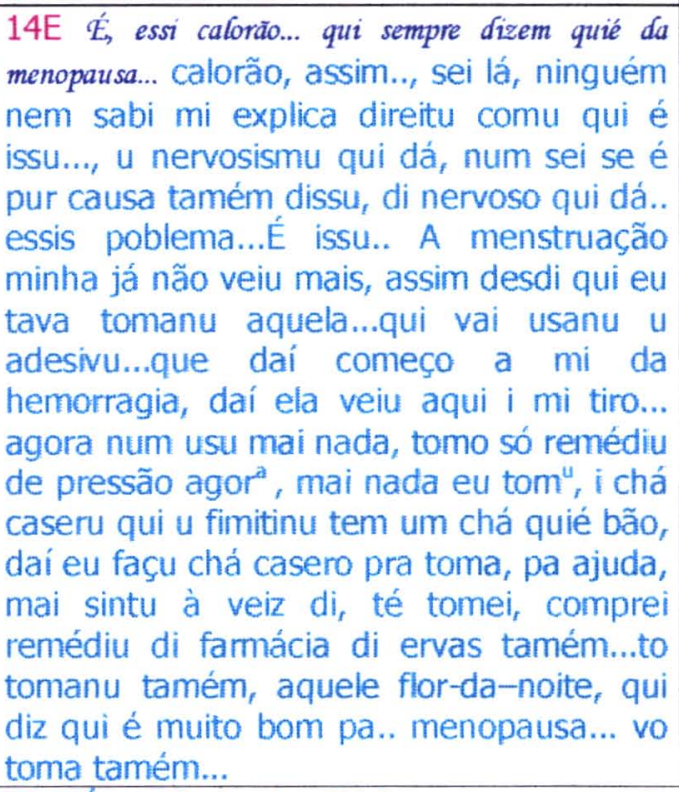 & $\begin{array}{l}\text { (1) Não sabe se o calorão é } \\
\text { da menopausa e ninguém } \\
\text { explicou direito o nervosismo } \\
\text { que sente ou se os problemas } \\
\text { são devido ao nervosismo. A } \\
\text { menstruação não veio mais } \\
\text { desde que usou o adesivo. } \\
\text { Daí deu hemorragia, foi } \\
\text { retirado e não usou mais. B } \\
\text { (2) Só toma remédios para a } \\
\text { pressão (alta), chá caseiro e } \\
\text { um da farmácia de ervas (flor- } \\
\text { da-noite) que dizem ser muito } \\
\text { bom para a época da } \\
\text { menopausa, pois acha que os } \\
\text { sintomas de calor e } \\
\text { nervosismo melhorarão. } \\
\text { E }\end{array}$ & $\begin{array}{c}\text { Todas as } \\
\text { mulheres } \\
\text { sofrem os } \\
\text { sintomas igual } \\
\text { a mim. } \\
\text { B }\end{array}$ \\
\hline $\begin{array}{l}15 \mathrm{E} \hat{E}_{r} \text { está sendo difícil por causa dessis } \\
\text { poblemas... qui depois de treis anu... }\end{array}$ & $\begin{array}{l}\text { (1) A menopausa está sen } \\
\text { difícil. B }\end{array}$ & \\
\hline
\end{tabular}




\begin{tabular}{|c|c|}
\hline $\begin{array}{l}\text { agora... começa o sangramentu tudu... Eu } \\
\text { achu qui issu aí num devia acontece... Deve } \\
\text { ter alguum.. motivu pá contece issu aí... }\end{array}$ & $\begin{array}{l}\text { (2) Depois de três anos sem } \\
\text { menstruação apresenta } \\
\text { sangramento novamente. } \\
\text { Acha que deve ter algum } \\
\text { motivo para isso. E }\end{array}$ \\
\hline $\begin{array}{l}\text { 16E Quase eu num tive, porque cum trinta } \\
\text { e dois anu... euo tivi qui extrai os ovário.... } \\
\text { Já tinha extraido um, dai tivi que extrai o } \\
\text { outru. Então, desdi então, sempri tomandu } \\
\text { u remediu... dava quele mal estar, queli } \\
\text { calorão, tudu aquelas coisa... então } \\
\text { menospausa..... craramente eu num tivi. } \\
\text { Hoji to sintinu purque foi mudadu u } \\
\text { medicamentu... pur causa dessi tratamentu } \\
\text { quie to fazenu... não estou me dando bem } \\
\text { com o otro medicamentu... então me dá } \\
\text { queli calorão, queli mal estar........ mas eu } \\
\text { vo até o fim, já ta terminanu a cartela pra } \\
\text { pode... vê u qui quieu vo faze daí }\end{array}$ & $\begin{array}{l}\text { (1) Extraiu os ovários muito } \\
\text { cedo, tendo mal-estar e } \\
\text { calorão. } \\
\text { (2) Desde então vem } \\
\text { tomando hormônio. Quase } \\
\text { não teve sintomas de } \\
\text { menopausa. } \\
\text { (3) Agora, o remédio foi } \\
\text { mudado, e está sentindo mal- } \\
\text { estar e calorão.Quer acabar a } \\
\text { cartela do remédio para ver o } \\
\text { que precisará fazer. } \\
\text { E }\end{array}$ \\
\hline $\begin{array}{l}\text { 17E Ah, ta sendu horrivel.... calorão, suadô, } \\
\text { às veiz depois vem uo friu... é terrivel. Ta } \\
\text { sendu dificil, bastanti. }\end{array}$ & $\begin{array}{l}\text { (1) A menopausa é horrivel, } \\
\text { terrivel, bastante difícil. B } \\
\text { (2) Traz calorão, suador e } \\
\text { depois vem o frio. E }\end{array}$ \\
\hline $\begin{array}{l}\text { 18E Quandu paro a menstruação? Ah, eu } \\
\text { sentia aquele calorãão..., de noite assim } \\
\text { dava queli friu, queli calorão mi discubria, } \\
\text { era tão.. uma sensação tão ruim... mal } \\
\text { estar..., dor di cabeça..., dor di cabeça, só } \\
\text { qui eu não fiz tratamentu. Eu num sei, } \\
\text { ninguém comento nada, não tinha } \\
\text { informação, então eu não fiz tratamentu. } \\
\text { Depois..., to melhoranu pur si mesmu, } \\
\text { fazenu chá em casa tomanu... é eu to } \\
\text { melhorandu... i comprimidu pa dor di } \\
\text { cabeça, bastanti... iiia saro por si tudu } \\
\text { aquilu, cum u tempu fui melhoranu, num } \\
\text { senti mais nada. Agora a preocupação é qui } \\
\text { to tomanu uuu hormôniu i ta descenu di } \\
\text { novu a menstruação. Pur causa duuu..., } \\
\text { tinha qui toma hormôniu pur causa dus } \\
\text { ossus, purque tinha us ossu muitu fracu... } \\
\text { cabelu cainu, a peli ta ficanu feia, ... Então } \\
\text { meu médicu sintiu, mincaminharu pra mim } \\
\text { faze um... um tratamentu, comecei a toma } \\
\text { u hormôniu... to mi sintinu bem melhor. Eu } \\
\text { não tenhu mais nem dor di cabeça, eu num } \\
\text { tenhu mai nada... U poblema é quiii nessa } \\
\text { submissa veiu minha menstruação desceu } \\
\text { dimais, dois dia ah oolhaaa, paricia uma } \\
\text { hemoragia, daí paro, mai aí depoi de uma }\end{array}$ & $\begin{array}{l}\text { (1) Quando parou a } \\
\text { menstruação sentiu aquele } \\
\text { calorão e frio, sensação ruim, } \\
\text { mal-estar, dor de cabeça, mas } \\
\text { não fez tratamento porque } \\
\text { não tinha informação para } \\
\text { isso. } \\
\text { E } \\
\text { (2) Depois foi melhorando } \\
\text { com chá caseiro e comprimido } \\
\text { para dor de cabeça. Agora } \\
\text { precisou tomar hormônio, por } \\
\text { causa dos ossos, cabelo e } \\
\text { pele, e a menstruação veio } \\
\text { novamente. } \\
\text { C } \\
\text { (3) É a única coisa que } \\
\text { incomoda porque achou } \\
\text { melhor ficar sem. Não sente } \\
\text { mais nada. }\end{array}$ \\
\hline
\end{tabular}




\begin{tabular}{|c|c|}
\hline $\begin{array}{l}\text { semana volto de novu. Agora paro, agora } \\
\text { eu queru sabe se vai volta de novu, purque } \\
\text { issu já é encomodu... tava tão bom sem } \\
\text { nada... Achei melhor sem... }\end{array}$ & \\
\hline $\begin{array}{l}\text { 19E Num paro ainda... é eu to tomanu } \\
\text { hormôniu.... Quandu paro eu senti um } \\
\text { calorão ..... Eu não tenhu apetiti sexual } \\
\text { mais. Cabo... Achu qui quanu eu tomu } \\
\text { calmante, às vezis quanu tomu calmante } \\
\text { dá... daí eu num tenhu vontadi. I quanu } \\
\text { tava tomanu hormôniu tamém num } \\
\text { ajudava... }\end{array}$ & $\begin{array}{l}\text { Tomou hormônios e continua } \\
\text { descendo a menstruação, mas } \\
\text { não tem apetite sexual, que } \\
\text { pode ser por causa do } \\
\text { calmante. O hormônio não } \\
\text { ajudou a melhorar esse } \\
\text { sintoma }\end{array}$ \\
\hline $\begin{array}{l}20 \mathrm{E} \text { To mi sintinu bemm, agora depois du } \\
\text { remediu qui a dotora me receito... }\end{array}$ & $\begin{array}{l}\text { Depois que a doutora receitou } \\
\text { o remédio (hormônio) está se } \\
\text { sentindo bem. D }\end{array}$ \\
\hline $\begin{array}{l}\text { 21E Ah, eu achei uma coisa boa, purque } \\
\text { menus a genti numsi incomoda todu } \\
\text { meis..., tem aquela preucupação... eu mi } \\
\text { sintu beim, ligui num tenhu nem um poco } \\
\text { de dor di cabeça, não tenhu calorão, não } \\
\text { tenhu indisposição, tenhu sempri disposição } \\
\text { di trabaiá, di faze tudu..., intão pra mim } \\
\text { num atingiu nada... i quanu eu tinha } \\
\text { monipausa (menstruação) eu sintia munta } \\
\text { cólica... cólica, num tinha vontade de.. faze } \\
\text { as coisa, mi doía u corpu interu... i hoji eu } \\
\text { mi sintu bem... }\end{array}$ & $\begin{array}{l}\text { Achou a menopausa uma } \\
\text { coisa boa porque a } \\
\text { menstruação mensal não } \\
\text { incomodou mais. Hoje está } \\
\text { bem: não tem dor de cabeça, } \\
\text { calorão, indisposição. Está } \\
\text { sempre disposta para } \\
\text { trabalhar e fazer tudo. } \\
\text { Menstruada sentia cólica, } \\
\text { dores no corpo todo, não } \\
\text { tinha vontade de fazer nada. } \\
\text { C }\end{array}$ \\
\hline $\begin{array}{l}\text { 22E Olha,.. num possu reclama, tirandu essi } \\
\text { calorão.. queu tinha até toma u remediu, } \\
\text { eu num, num outra coisa num tinha, num } \\
\text { tinha mais nada, daí eu comecei, até lá } \\
\text { ondi eu trabalho, tinha sangrado a..., tinha } \\
\text { saídu sangui da boca e du nariz um dia de } \\
\text { noite i eu comentei lá, pur issu quieu vim } \\
\text { nu médicu, daí a menina lá, entendeu? " } \\
\text { ce tem qui i no médico, tem qui i nu } \\
\text { médicu", senão num tinha nem procuradu u } \\
\text { médicu, porque assim eu mi sentia bem, } \\
\text { tiranu o calorâo, eu num tinha mai nada, só } \\
\text { u calorão mesmu... }\end{array}$ & $\begin{array}{l}\text { (1) Acha que não pode } \\
\text { reclamar. Só foi ao médico } \\
\text { por insistência da filha da } \\
\text { patroa. } \\
\text { (2) Teve somente o calorão e } \\
\text { sangramento pela boca e } \\
\text { nariz } \\
\text { E }\end{array}$ \\
\hline $\begin{array}{l}\text { 23E A menopausa pra mim ta senuuu } \\
\text { normal porque eu to tratandu... Intão pra } \\
\text { mim num pesa, ta senu sem problema... Eu } \\
\text { mi sintu bem, ótima... }\end{array}$ & $\begin{array}{l}\text { A menopausa não está sendo } \\
\text { problema porque trata há } \\
\text { tempos. Sente-se bem, ótima. } \\
\text { A }\end{array}$ \\
\hline $\begin{array}{l}\text { 24E Ah, a menopausa pra miiim éé... eu } \\
\text { num to achanu muita diferença, a única }\end{array}$ & \\
\hline
\end{tabular}




\begin{tabular}{|c|c|c|}
\hline $\begin{array}{l}\text { diferença é qui eu to mais ixplosiva... Mais } \\
\text { irritada, mais irritada... assimmm, otrus } \\
\text { poblema sim eu nuu, nu to tenu.... Sintu } \\
\text { um poco di calor... i essa tontura... quieu to } \\
\text { sentinu... quieu achu qui tem arguma coisa } \\
\text { a vê,, porque sempri quieu to assim cum } \\
\text { tontura quieu to pertu di farmácia, eu corru } \\
\text { lá, ela medi a minha pressão ta sempri boa, } \\
\text { Então a coisa quieu to achanu diferenti é } \\
\text { issu... essaa .. tontura qui mi dá de veiz em } \\
\text { quandu. E eu achu qui devi ta ligada à } \\
\text { menopausa, porque eu não tinha antis... } \\
\text { num tinha antis... }\end{array}$ & $\begin{array}{l}\text { (1) Não sente muita } \\
\text { diferença. } \\
\text { A } \\
\text { (2) Só está mais irritada e } \\
\text { explosiva, tem um pouco de } \\
\text { calor e tontura que acha ser } \\
\text { da menopausa porque já } \\
\text { mensurou a pressão várias } \\
\text { vezes e não estava alterada, e } \\
\text { não sentia nada disso antes } \\
\text { da menopausa } \\
\text { E }\end{array}$ & \\
\hline $\begin{array}{l}\text { 25E Olha, a menopausa minha foi uma } \\
\text { coisa bem complicada... Porque eu fiqueeii, } \\
\text { quando começo minha menopausa, eu } \\
\text { fiquei treis meis cum cólica... ii, issu aí eu } \\
\text { num prucurava médicu purqueu trabalhava } \\
\text { todas, tudo dia, eu falava pra minha mãe, } \\
\text { minha sogra qui aquilu era uma coisa } \\
\text { nomal... dai quando eu fui na } \\
\text { ginecologista, eli falo "*** não podi, ondi } \\
\text { qui si viu issu aí num ixisti" "você ta } \\
\text { anêmica, você ta fico doenti e não foi ao } \\
\text { médicu ?", daí eu foi fazeee corretagi, daí } \\
\text { já ... eu tinha muitu calorããoo, aquefis pesu qui } \\
\text { toda muther senti.. Iii, dai depois quieu fiz a } \\
\text { corretagi, fiquei cum cólica mais três } \\
\text { mesis, daí... paro, não veiu mais nada, } \\
\text { nada, i daí eu só sintia calorão, mal-estar, } \\
\text { aquelaaa ... o sexu já foi diminuindu, num } \\
\text { tinha mais vontadi, pra mim si tivessi tudu } \\
\text { bem, si num tivessi num tinha mai nada...I } \\
\text { daí, já fui uma pessoa mais .... cabo } \\
\text { aqueliss ... prazer di tudu, ii já comecei a } \\
\text { engordaaa, daí já tivi problema di bixiga } \\
\text { caída... dai faiz um anu qui ta feita a } \\
\text { cirurgia, i agora eu continuo, calorão, achu } \\
\text { qui to pricisanu di repor hormôniu, tem qui } \\
\text { faze meus ixami di volta, eu achu qui ééé, } \\
\text { nâo sei si tem mais algum problema di } \\
\text { menopausa, mais u quieu sintu é issu... } \\
\text { Euo, comu eu assistu uum, uma falência na } \\
\text { televisão todas quinta-fera, cum dotor... eu } \\
\text { acompanhu é sobri issu, eli orienta muita } \\
\text { genti... i comu eu to passanu pur issu, eu } \\
\text { falu "já quieu num possu ta inu nu médicu } \\
\text { cumeçu a orienta assim", resolve, purque } \\
\text { aquilu si é normal aquilu quieu to sintinu o } \\
\text { não... Purque a genti fica meio assim, num }\end{array}$ & $\begin{array}{l}\text { (1) A menopausa foi bem } \\
\text { complicada está em uma fase } \\
\text { difícil. } \\
\text { B } \\
\text { (2) Esteve três meses com } \\
\text { cólica. Quando foi ao } \\
\text { ginecologista precisou fazer } \\
\text { curetagem e estava anêmica. } \\
\text { Daí ficou com cólica mais três } \\
\text { meses e não veio mais (a } \\
\text { menstruação), deu calorão, } \\
\text { mal-estar, o sexo foi } \\
\text { diminuindo, perdeu o prazer } \\
\text { sexual engordou, teve } \\
\text { problemas de bexiga, foi para } \\
\text { cirurgia que complicou. Acha } \\
\text { que precisa repor os } \\
\text { hormônios porque ainda tem } \\
\text { muito calor. Assiste um } \\
\text { programa na televisão que } \\
\text { orienta sobre a menopausa } \\
\text { porque acha que não sabe } \\
\text { muita coisa sobre isso e } \\
\text { pensa que todo mundo que } \\
\text { manda perguntas (para o } \\
\text { programa) passa por essa } \\
\text { fase que considera difícil, com } \\
\text { dor de cabeça e nas pernas, } \\
\text { com varizes, às quais atribui à } \\
\text { menstruação retida. } \\
\text { E E }\end{array}$ & $\begin{array}{c}\text { Todas as } \\
\text { mulheres } \\
\text { sofrem os } \\
\text { sintomas igual } \\
\text { a mim. } \\
B\end{array}$ \\
\hline
\end{tabular}


tem muitaaa a genti num sabi, muita coisa, ... Intãão, ta, todu mundu senti u mesmu quieu sintu, Daí eu tenhu dor di cabeça... sintu muita dor nas perna, agora tamém estoro bastanti varizis, tamém a genti paro di fica menstruada, intão muita dor nas perna, muitaaaa .. fica tudu muitu paradu, sei lá, se é issu, né.... Intâo, achu qui ééé, sei lá si todu mundu passa pur issu aí, eu to passanu, né, por essa fasi... Agora, ta uma fasi dificil ...

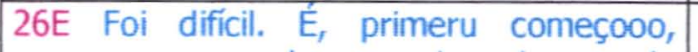
começo cum hemorragia, i aquela hemorragia fico dois anu digamus assim pra iquilibra; demoro. foi recuperanu i graças qui agora eu to, to achanu qui ta melhor... Com atendimento da dotora S., eu achei qui si não fosse ela, nem viva eu num estava. Porque a hemorragia muito tempu, ela acabo cumigu, eu fraca, muitu fraca, fraca, oi istres nu últimu, eu vim aqui cu istres lá im, lá imbaxu...Intão, ela mi deu remediu i agora devu a vida à dotora.

27E ...a sensação quieu sintu? É, tenhuuu, a sensação tenhu calor, nas costas bastant , qui dá i sobi pa cabeça, á noit aí não consigu mi cubri.. É u quieu mais quieu sintu, ... Sintu bastant necessidad' di come assim, mai não, mi controlu porque, por causa du meu pesu qui ta muitu. Eu achu qui é issu quieu sintu.. Iii, tem mais, dificuldadi di assuntu assim, porque tamem não tenhu vontade de ... manter relação sexual, não, não tenhu. Essi, eu tamém não tenhu não. Não mudo a vida com o marido porque eli também é meiu assim, eli entende, bastant, eli tamém tem um poco de dificuldade por causa do poblema deli, tamém eli já fez cirurgia do coração, então já fico mais.... é uma coisa qui não fico muitu...

28E Eu me sintuuu.. calor, dor di cabeça i friu na hora qui dá u calor i é só... mais forti é. É u qui mais incomoda é issu. Otras coisa num mincomoda muitu... Quanu começo eu fiquei muntu nervosa, foi quandu começo a monopausa foi quieu fiquei assim ...

(1) A menopausa foi dificil e o que resolveu foi 0 atendimento e a medicação que a médica proporcionou. Acha que the deve a vida.

(2) Começou com uma hemorragia da qual levou dois anos para se recuperar. Ficou muito fraca, com estresse.

A menopausa deu uma sensação de calor nas costas que sobe para a cabeça, deixando-a ansiosa, comendo muito e com insônia.Porém, controla-se por causa do peso. Diminuiu a vontade de manter relação sexual, mas não mudou muito com 0 marido, porque ele também enfrenta dificuldades sexuais por ser cardíaco.

\section{E}

(1) A menopausa incomoda. B

(2) Trouxe a sensação de calor e frio, e dor de cabeça. Quando começou ficou muito nervosa. E 


\begin{tabular}{|c|c|}
\hline $\begin{array}{l}\text { eu sintia, sintia mal, agora não, agora to } \\
\text { bem... Mais tem qui controla, purque si } \\
\text { não controla vai começa tudu u calorão de } \\
\text { novu. Eu controlu tomanu hormônio, } \\
\text { Nossa Senhora, coisa mai horrivel du } \\
\text { mundu!!! Senti assim... parece qui tu ta... } \\
\text { muda completamenti a vida, num sei... } \\
\text { Você num tem aqueli, aquela paaz, aquela } \\
\text { coisa, ... A genti qué ta beim, de repente, ó } \\
\text { brup, muda na hora.... Então é dificil } \\
\text { dimais... }\end{array}$ & $\begin{array}{l}\text { demais, é a coisa mais } \\
\text { horrivel do mundo. } \\
\text { B } \\
\text { (2) Deu a sensação de calorão } \\
\text { e mal-estar que controla bem } \\
\text { com hormônio; mudou } \\
\text { completamente a sua vida; } \\
\text { não tem mais paz; quer estar } \\
\text { bem e de repente muda. } \\
\text { E }\end{array}$ \\
\hline $\begin{array}{l}\text { 30E Ah, eu começo cum assim, ah, quelis } \\
\text { calorão, muitu nervosa... tontura bastanti... } \\
\text { bastanti tontura, iii, assim eu num mi sintia } \\
\text { bem, eu sempri tava assim uma coisa ruim } \\
\text { assim, num tava disposta pra nada,... não } \\
\text { tinha vontade de nem de faze as coisa } \\
\text { assim... mias issu foi passandassim por } \\
\text { causa que... quandeu fui, fiz a minha } \\
\text { cirurgia, dai eu pedi pra ele "dotor, agora } \\
\text { qui tem a cirurgia não vo mais ter a } \\
\text { mestruação, dai não precisa de faze um } \\
\text { tratamentu pra menopausa?" Eli disse: } \\
\text { "Não, quem sabi não precisa, nấo precisa } \\
\text { ser..." E dai qui meu filho começo a fica } \\
\text { doenti, e daí eu me dediquei pra eli.. i } \\
\text { nunca mais fui.. a procura dessi } \\
\text { tratamentu, i agora ultimamente ali eu } \\
\text { comecei a fica ruim, a fica ruim, fica ruim.. } \\
\text { daí foi qui daí intão eu fiz o meu } \\
\text { preventivo, dai no meu preventivo acuso } \\
\text {..queu tinha que faze u tratamentu cuma ... } \\
\text { ginecologista, ... Eu tava com trinta e novi } \\
\text { anus quandu entrei na menopausa, a } \\
\text { médica falo quieu era nova, queu tinha que } \\
\text { começa logu a faze essi tratamentu, } \\
\text { trintenovi anu, eu tinha quandu eu tirei o } \\
\text { útero.... Hoji eu uso adesivu... }\end{array}$ & $\begin{array}{l}\text { A menopausa começou } \\
\text { precocemente com calorão, } \\
\text { muito nervosismo, tontura, } \\
\text { mal-estar sempre, sem } \\
\text { disposição. Fez a cirurgia } \\
\text { (histerectomia) e soube pelo } \\
\text { médico a possibilidade de } \\
\text { ocorrer uma reposição de } \\
\text { hormônios. Porém, seu filho } \\
\text { ficou doente (leucemia) e } \\
\text { dedicou-se a ele, nunca mais } \\
\text { procurando tratamento. Agora } \\
\text { (depois que o filho faleceu) } \\
\text { fez o preventivo que acusou a } \\
\text { necessidade de atendimento } \\
\text { ginecológico. } \\
\text { encaminhada e está usando } \\
\text { adesivo. }\end{array}$ \\
\hline
\end{tabular}

\section{INSTRUMENTO DE ANÁLISE DE DISCURSO 2}

\section{Questão 1 Como está sendo a menopausa para você?}

\section{A = A menopausa não é um período tão difícil de ser enfrentado}

\begin{tabular}{|c|c|}
\hline EXPRESSÕES-CHAVE & DISCURSO DO SUJETTO COLETIVO \\
\hline $\begin{array}{l}\text { (1) Não deu nem pra senti, Então eu acho } \\
\text { que a menopausa não ta assim sendo... ah, }\end{array}$ & $\begin{array}{c}\text { Não deu para sentir, porque a menopausa } \\
\text { não está sendo um bicho terrivel que todos }\end{array}$ \\
\hline
\end{tabular}


aquele bicho de cabeça..., aqueli, aquela coisa que todo mundo diz que é muito terrivel, aquela... num to sentindu, não.

(2) Olha, eu acho assim, eu to começando... aqueles calorões que é o famoso, Ta poco ainda , né, mais já começo, I o resolvi procura meios, Então..., ta razoável pur enquantu tá razoável. Ainda to dando conta do que sinto.

(4) menstruação, faiz uns... uns oito anu já...cabo assim daí..., sabi eu mi sintu bem em tudu... pra mim sempri foi tudu bem,

(22) Olha,... num possu reclama, dai a menina lá, entendeu? "ce tem qui i no médico, tem qui i nu médicu", senão num tinha nem procuradu u médicu, porque assim eu mi sentia bem,

(24) Ah, a menopausa pra miiim éé, eu num to achanu muita diferença dizem, não estou sentindo assim. Agora está começando aqueles calorões famosos, está pouco ainda, está razoável e ainda estou dando conta do que sinto. Eu me sinto bem em tudo depois que parou a menstruação natural ou cirurgicamente. Não posso reclamar. $\mathrm{Na}$ verdade eu não teria nem procurado o médico se alguém não tivesse insistido, porque eu me sentia bem. Enfim, não estou achando diferença.

\section{$B=A$ menopausa é um período difícil de ser enfrentado}

\section{EXPRESSÕ̃S-CHAVE}

(3) É horrível, Péssima!!, e daí é horrivel, ... Por issu to buscando ajuda, sim pra vida toda....

(6) Ah, a minha dificuldade dela..., é qui ingorda. Então, a dificuldade minha é esse negóciu di cria mais é.. seiu, quadril, essas coisa, Só minha dificuldade é essa, purque eu perdi toda minha ropa. Então a dificuldade é essa....

(7) Olha, menopausa ta sendo um poblema muuito sério pra mim,

(8) também to pensando três anos qui sofri..., então eu acho que, qui pra mim ta sendo bem difícil, purque eu moro sozinha, e ta sendo bem dificil pra mim. Por isso to buscando tratamento, to buscando já ta com três ano queu to atrás de faze tratamento. Mas só que num deu certo de faze,

(9) Achu qui ta, ta sen " muit" dificil.

(11) Ah, sab' que judio bastanti... Mais agora já carmo, num ta taaanto mais aqueli calorão mais...

(12) antis de para eu fiquei muito calorzão, tinha muita frição, Mais agor ${ }^{a}$ depois qui paro, eu sintu bem, só num sintu bem pur casu.. muito bem assim, pur casu tem muita dor di cabeça ainda, mais eeu, recramu só da pressão alta, ... Eu tomu remédiu pra pressão.

\section{DISCURSO DO SUJEITO COLETIVO}

A menopausa é terrivel, péssima, está sendo bem difícil, é um problema muito sério pensando no sofrimento que tive. Judiou bastante, tinha muita aflição, foi bem complicada, Nossa Senhora! Foi a coisa mais horrível do mundo! Tive problemas de calorão, falta de ar, dor de cabeça, pressão alta, aumento de peso, chegando a perder todas as minhas roupas. Com o calorão e a insônia incomodava o marido de tanto que me movimentava à noite. Mas também é difícil para quem mora sozinha passar por todo problema. Por isso fui procurar tratamento há um tempo e só agora deu certo. Com o atendimento estou me sentindo bem, acalmou os sintomas, mas se não fosse a doutora acho que nem viva estava. 
(13) É um poco difícil, né? Meu maridu fica acomodadu, i fala "Poxa, mais ce dormi", $I_{f}$ mais ié eu qui to cum calorão, cumé qui vo faze.

(15) É, está sendo difícil

(16) Hoji to sintinu purque foi mudadu u medicamentu, pur causa dessi tratamentu quie to fazenu, não estou me dando bem com o otro medicamentu... então me dá queli calorão, queli mal estar...

(17) Ah, ta sendu horrivel.... é terrivel. Ta sendu difícil, bastanti.

(18) Como assim, menopausa? Quandu paro a menstruação? Ah, eu sentia aquele calorãão..., de noite assim dava queli friu, queli calorão mi discubria, era tão.. uma sensação tão ruim, mal estar..., dor di cabeça..., só qui eu não fiz tratamentu. Eu num sei, ninguém comento nada, não tinha informação, então eu não fiz tratamentu.

(25) Olha, a menopausa minha foi uma coisa bem complicada, sabi?

(26) Foi dificil. ... Com atendimento da dotora $S_{\text {., }}$ eu achei qui si não fosse ela, nem viva eu num estava. Intão, ela mi deu remediu i agora devu a vida à dotora

(28) Eu me sintuuu.. calor, dor di cabeça i friu na hora qui dá u calor i é só... mais forti é.

(29) Nossa Senhora, coisa mai horrivel du mundu!!! Então é difícil dimais.

\section{$\mathrm{C}=\mathrm{A}$ menopausa é um período melhor que a fase reprodutiva}

\begin{tabular}{|c|c|}
\hline EXPRESSOÕES-CHAVE & DISCURSO DO SUJEITO COLETIVO \\
\hline $\begin{array}{l}\text { (10) Ah, eu creiu qui ta senu bom pra mim, } \\
\text { purque eu já tenhuua, queu num tenhu mais } \\
\text { menstruação, mais a minha vida continuaa.. } \\
\text { igual, tantu na manera di do meu } \\
\text { casamento, se falanu em sexu, vamu dize, } \\
\text { continua sendo igual pra mim, então eu num } \\
\text { tive problemas nessa área... di.. di qui paroo, } \\
\text { a coisa mudoo, tendeu? pra mim continua } \\
\text { senu a mesma forma, por exemplo, siii } \\
\text { antigament }{ }^{e} \text { quando se tem menstruação é } \\
\text { difícil, muitas vezes se tem dores, i eu num } \\
\text { tenhu nada, eu mi sintu super bem. } \\
\text { (18) Agora paro, agora eu queru sabe se vai } \\
\text { volta de novu, purque issu já é encomodu, } \\
\text { tava tão bom sem nada... Achei melhor sem } \\
\text { (21) Ah, eu achei uma coisa boa. purque }\end{array}$ & $\begin{array}{l}\text { O período de menopausa tem sido bom para } \\
\text { mim: eu não tenho mais menstruação, mas a } \\
\text { vida continua igual no casamento porque não } \\
\text { tive problemas na área sexual, tudo continua } \\
\text { da mesma forma, nada mudou. Antigamente, } \\
\text { quando tinha a menstruação era difícil, } \\
\text { muitas vezes tinha dores no corpo, muita } \\
\text { cólica, indisposição. Isso é um incômodo, a } \\
\text { gente tem aquela preocupação todos os } \\
\text { meses. Agora que parou achei melhor ficar } \\
\text { sem a menstruação. Eu não tenho nada, não } \\
\text { me atingiu em nada, não tenho dor de } \\
\text { cabeça, não tenho calorão, não tenho } \\
\text { indisposição, me sinto super bem em tudo. }\end{array}$ \\
\hline
\end{tabular}


menus a genti numsi incomoda todu meis..., tem aquela preucupação... eu mi sintu beim, num tenhu nem um poco de dor di cabeça, não tenhu calorão, não tenhu indisposição, tenhu sempri disposição di trabaiá, di faze tudu..., intão pra mim num atingiu nada.. i quanu eu tinha monipausa (menstruação) eu sintia munta cólica... cólica, num tinha vontade de.. faze as coisa, mi doía u corpu interu... i hoji eu mi sintu bem...

\section{D =A menopausa com tratamento não é nada}

\begin{tabular}{|c|c|}
\hline EXPRESSÕ̃ES-CHAVE & DISCURSO DO SUJEITO COLETIVO \\
\hline $\begin{array}{l}\text { (5) mas daí eu procurei um tratamento } \\
\text { agora...é mais nada... agora eu to me } \\
\text { sentindo bem. } \\
\text { (11) Mais agora já carmo, num ta taaanto } \\
\text { mais aqueli calorão mais... } \\
\text { (13) Nossa, quandu eu num tomu, aí u } \\
\text { negóciu fica feio mesmu, dai piora, } \\
\text { (14) A menstruação minha já não veiu mais, } \\
\text { assim desdi qui eu tava tomanu aquela...qui } \\
\text { vai usanu u adesivu, agora num usu mai } \\
\text { nada, tomo só remédiu de pressão agor }{ }^{2} \text {, } \\
\text { mai nada eu tom" , i chá caseru qui u fimitinu } \\
\text { tem um chá quié bão, daí eu façu chá casero } \\
\text { pra toma, pa ajuda, mai sintu à veiz di..., té } \\
\text { tomei, comprei remédiu di farmácia di ervas } \\
\text { tamém, to tomanu tamém, aquele flor-da- } \\
\text { noite, qui diz qui é muito bom pa.. } \\
\text { menopausa, vo toma tamém... } \\
\text { (15) agora... começa o sangramentu tudu, ... } \\
\text { Eu achu qui issu ai num devia acontece, } \\
\text { Deve ter alguum.. motivu pá contece issu } \\
\text { aí... } \\
\text { (16) Quase eu num tive, porque cum trinta e } \\
\text { dois anu, euo tivi qui extrai os ovário, Já } \\
\text { tinha extraido um, daí tivi que extrai o outru. } \\
\text { Então, desdi então, sempri tomandu u } \\
\text { remediu... Hoji to sintinu purque foi mudadu } \\
\text { u medicamentu, pur causa dessi tratamentu } \\
\text { quie to fazenu, não estou me dando bem } \\
\text { com o otro medicamentu... então me dá } \\
\text { queli calorão, queli mal estar..., mas eu vo } \\
\text { até o fim, já ta terminanu a cartela pra } \\
\text { pode... vê u qui quieu vo faze dai, } \\
\text { (18) comecei a toma u homôniu, to mi } \\
\text { sintinu bem melhor... Agora a preocupação é } \\
\text { qui to tomanu uuu hormôniu i ta descenu di } \\
\text { novu a menstruação tinha qui toma } \\
\text { hormôniu pur causa dus ossus, purque tinha }\end{array}$ & $\begin{array}{l}\text { A menopausa está sendo normal porque } \\
\text { estou tratando. Desde que procurei } \\
\text { tratamento passei a tomar o hormônio, o } \\
\text { remédio que a doutora receitou e estou } \\
\text { me sentindo bem melhor, ótima. Então, } \\
\text { não pesa, está sendo sem problemas. } \\
\text { Pouca ou muita tontura, dor de cabeça e } \\
\text { embaraçamento da visão retornam se } \\
\text { deixo de tomar a medicação. Enquanto } \\
\text { realizava os exames para saber a } \\
\text { necessidade e possibilidade de reposição } \\
\text { hormonal tomava remédios para } \\
\text { melhorar alguns sintomas. Chás caseiros } \\
\text { e remédios da farmácia de ervas também } \\
\text { dizem que ajudam a melhorar o calorão. } \\
\text { Tomando hormônios ou usando adesivo } \\
\text { o efeito pode não ser o desejado, mas } \\
\text { pode aliviar as sensações e não ter mais } \\
\text { problemas. A mudança de medicação ou } \\
\text { de dose, ou ainda, parar de tomar o } \\
\text { hormônio pode trazer de volta as más } \\
\text { sensações. Ficar sem repor o hormônio } \\
\text { pode deixar os ossos e os cabelos fracos, } \\
\text { a pele feia, porém, às vezes a } \\
\text { menstruação retorna e até a hemorragia. } \\
\text { Agora eu estou me sentindo bem com o } \\
\text { remédio que a doutora me receitou e } \\
\text { acho que tem que controlar tomando } \\
\text { hormônio para não começar tudo de } \\
\text { novo; está normal porque estou } \\
\text { tratando. }\end{array}$ \\
\hline
\end{tabular}


us ossu muitu fracu, cabelu cainu, a peli ta ficanu feia, ... comecei a toma u hormôniu, to mi sintinu bem melhor. Eu não tenhu mais nem dor di cabeça, eu num tenhu mai nada.. U poblema é quiii nessa submissa veiu minha menstruação desceu dimais, dois dia ah oolhaaa, paricia uma hemoragia, daí paro, mai ai depoi de uma semana volto de novu. (19) é eu to tomanu hormôniu.... Quandu paro eu senti um calorão .....

(20) To mi sintinu bemm, agora depois du remediu qui a dotora me receito...

(22) queu tinha até toma u remediu, num outra coisa num tinha...

(23) A menopausa pra mim ta senuuu normal porque eu to tratandu, Intão pra mim num pesa, ta senu sem problema... Eu mi sintu bem, ótima...

(24) ...Então a coisa quieu to achanu diferenti é issu, essaa .. tontura qui mi dá de veiz em quandu.

(25) achu qui to pricisanu di repor homôniu, tem qui faze meus ixami di volta...

(29) Mais tem qui controla, purque si não controla vai começa tudu u calorão de novu. Eu controlu tomanu hormônio...

\section{$\mathbf{E}=\mathrm{A}$ menopausa apresenta sinais e sintomas biológicos}

\begin{tabular}{|l|}
\hline EXPRESSÕES - CHAVE \\
\hline (1) Pur causa que...é tiran, o calorão já \\
sentia nu nomal, Por causa da pressão alta \\
i... depois que é... acho que quando eu \\
entrei na menopausa foi... não senti nada \\
assim diferente.. Tá tranqüilo, tirando o \\
excesso de gordura, essa....é, cansera, quié, \\
aquele calorão, que no geral não sintu..., \\
frio, sempre fui encalorada \\
(2) aqueles calorôes que é o famoso, é
\end{tabular} justamente pelo fato de... di

(3) Calorão...

(4) Agora pra mim eu num,.. senti aqueles calor, aquelas coisa qui nem as mulher falam, sabi... Só num consigo usa essas coisa fechada assim qui nem a blusa... Nunca consegui...

(5) eu já tive problema de calorão, senti falta de $a r_{t}$

(6) é qui ingorda, ...Ainda bem que eu num preciso repor hormônio, Qui eu precisasse aí ia fica dificil, Purque dai queu ia ingorda
DISCURSO DO SUJEITO COLETIVO

Na menopausa (natural ou cirúrgica, em tempo ou precoce) o calorão pode ser aquele comum que eu já sentia normalmente não conseguindo usar roupas fechadas; ou o calorão famoso, como as mulheres falam, que dá suador, e pode ser seguido de frio, ou que aparece nas costas e sobe para a cabeça, ou ainda aquele que precisa tomar banho duas, três vezes ao dia, mesmo no inverno. Além dos calorões, depois que entrei na menopausa fiquei com excesso de peso, precisando controlar o quê e quanto comer. A pressão (arterial) ficou instável ou alta, podendo infartar. Tenho canseira (ou fadiga) e falta de ar. Às vezes, a menopausa inicia com cólicas e peso (abdominal), hemorragia vaginal ou nasal que levam a uma anemia e uma fraqueza profunda. As varizes dolorosas, causadas pela menstruação suspensa, e os problemas de bexiga aparecem e perturbam a rotina da vida, ou às vezes, como as 
mesmo, ...e até mi deu remédio i tudo, Eu num tomei, não. Ai..., claru nunca eu precisei dissu, ...Nunca tomei anticoncepcional, então agora num vo toma, To na menopausa, Num precisu toma

(7) eu tenho muuito calor, eu tenhu qui toma banhu, duas, treis vezis, eu me., dipois quieu tive aqui a primeira vez, fiquei bem pior. Minha pressão não normaliza, as veis ta doze por nove, assim como sobe e podi infarta... mas no meu limite mesmo, purque pode aumenta di cansera,

(8) agora vô vê o que o médico vai fala, é pra opera a gente opera, si num é tamém a gente vai fica, purque... u serviçu... Então, é isso aí quieu to passano.

(11) Ééé, por causa do calorão...

(12) porque a minha menopausia i antis de para eu fiquei muito calorzão, ... pur casu tem muita dor di cabeça ainda, mais eeu, recramu só da pressão alta, Eu tomu remédiu pra pressão. Não tomu hormônio pur enquantu não. Pur enquantu não purque a dotora falo qui tem qui faze todu tratamento pra toma, Aí ela pidiu us tratamento di modu eu pude toma. Num tumei nenhum ainda.

(13) a menopausa é muitu calorão... um poco di tontura, às vezes me dá um poquinho di dor di cabeça, mais é bem poquinho, eu tomanu comprimiidu, diminuiu um poco... Dá aquele suado assim... i as vezi mi dá embaçamento di vista tamém, quanu ta pra vim, daí eu ficu com a vista meio imbaraçada. Assim.. inxergu quelas luuziinha correnu,

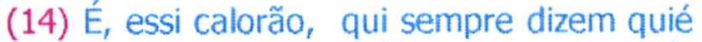
da menopausa, calorão, assim.., sei lá, ninguém nem sabi mi explica direitu comu qui é issu...,

(15) por causa dessis poblemas, qui depois de treis anu,

(16) euo tivi qui extrai os ovário, dava quele mal estar, queli calorão, tudu aquelas coisa, então menospausa..... craramente eu num tivi.

(17) calorão, suadô, às veiz depois vem uo friu...

(18) Ah, eu sentia aquele calorãão..., de noite assim dava queli friu, queli calorão mi discubria, era tão.. uma sensação tão ruim, mal estar..., dor di cabeça..., só qui eu não

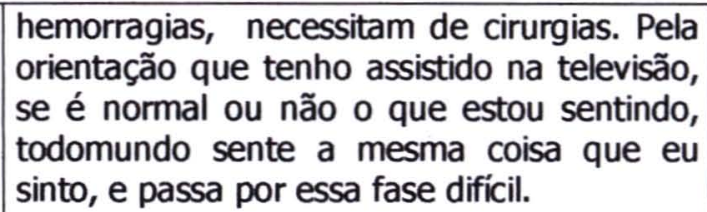

hemorragias, necessitam de cirurgias. Pela orientação que tenho assistido na televisão, se é normal ou não o que estou sentindo, todomundo sente a mesma coisa que eu sinto, e passa por essa fase dificil. 
fiz tratamentu. Eu num sei, ninguém comento nada, não tinha informação, então eu não fiz tratamentu...

(22) tirandu essi calorão.. num tinha mais nada, daí eu comecei, até lá ondi eu trabalho, tinha sangrado, tinha saídu sangui da boca e du nariz um dia de noite i eu comentei lá, pur issu quieu vim nu médicu, tiranu o calorão, eu num tinha mai nada, só u calorão mesmu

(24) Sintu um poco di calor, i essa tontura, quieu to sentinu, quieu achu qui tem arguma coisa a vê, porque sempri quieu to assim cum tontura quieu to pertu di farmácia, eu corru lá, ela medi a minha pressão ta sempri boa. E eu achu qui devi ta ligada à menopausa, porque eu não tinha antis...

(25) Porque eu fiqueeii, quando começo minha menopausa, eu fiquei treis meis cum cólica, "você ta anêmica", daí eu foi fazeee corretagi, daí já ... eu tinha muitu calorããoo, aquelis pesu qui toda mulher senti, Iii, dai depois quieu fiz corretagi, dai fiquei cum cólica mais três mesis, daí... paro, não veiu mais nada, nada, nada, i daí eu só sintia calorão, mal-estar, .... il já comecei a engordaaa, dai já tivi problema di bixiga caída, dai faiz um anu qui ta feita a cirurgia, i agora eu continuo, calorão... eu achu qui ééé, não sei si tem mais algum problema di menopausa, mais u quieu sintu é issu, bi... Euo, eu assistu uum, uma falência na televisão todas quinta-fera, cum dotor... eu acompanhu é sobri issu, eli orienta muita genti, i comu eu to passanu pur issu, eu falu "já quieu num possu ta inu nu médicu cumeçu a orienta assim", resolve, purque aquilu si é normal aquilu quieu to sintinu o não, Purque a genti fica meio assim, a genti num sabi, muita coisa, . Intãão, ta, todu mundu senti u mesmu quieu sintu, Daí eu tenhu dor di cabeça.. sintu muita dor nas perna, agora tamém estoro bastanti varizis, tamém a genti paro di fica menstruada, intão muita dor nas perna, muitaaaa .. fica tudu muitu paradu, sei lá, se é issu, .... Intão, achu qui ééé, sei lá si todu mundu passa pur issu ai, eu to passanu, por essa fasi... Agora, ta uma fasi difícil ...

(26) É, primeru começooo, cum hemorragia, i aquela hemorragia fico dois anu digamus assim pra iquilibra; demoro. Porque a 


\begin{abstract}
hemorragia muito tempu, ela acabo cumigu, eu fiquei fraca, muitu fraca, fraca, oi istres nu últimu, eu vim aqui cu istres lá im, lá imbaxu...

(27) É, tenhuuu, a sensação tenhu calor, na nas costas bastant', qui dá i sobi pa cabeça, á noit' aí não consigu mi cubri.. É u quieu mais quieu sintu, ... Sintu bastant necessidad $^{i}$ di come assim, mai não, mi controlu porque, por causa du meu pesu qui ta muitu. Eu achu qui é issu quieu sintu..

(28) Eu me sintuuu.. calor, dor di cabeça i friu na hora qui dá u calor i é só... mais forti é.

(29)Ah, eu comu tava assim cum calorão, eu sintia, sintia mal, agora não, agora to bem... (30) Ah, eu começo cum quelis calorão, ...tontura bastanti, bastanti tontura, i agora ultimamente ali eu comecei a fica ruim, a fica ruim, fica ruim.. dai foi qui eu fiz o meu preventivo, daí no meu preventivo acuso ..queu tinha que faze u tratamentu cum a .. ginecologista,... Eu tava com trinta e novi anus quandu entrei na menopausa, a médica falo quieu era nova, queu tinha que começa logu a faze essi tratamentu, trintenovi anu, eu tinha quandu eu tirei o útero.... Hoji eu uso adesivu...
\end{abstract}

\title{
$\mathbf{F}=\mathrm{A}$ menopausa traz também resultados psicossociais
}

\begin{tabular}{|c|c|}
\hline EXPRESSÕES-CHAVE & DISCURSO DO SUJETTO COLETIVO \\
\hline $\begin{array}{l}\text { (2) já num to tendo mais desejo sexual... eu } \\
\text { sinto prazer mas num tenho aquela vontade } \\
\text { como toda... nu começo a gente tem, } \\
\text { (7) dipois quieu tive aqui a primeira vez, } \\
\text { quiessa é a.. tercera veiz quieu estou aqui, } \\
\text { Mi sintu tristi ... purque a gente num } \\
\text { consegui vim aqui, ... era pra mim ter vindo } \\
\text { aqui em abril, agora qui o posto conseguiu } \\
\text { pra mim volta qui. Então a gente num } \\
\text { consegue faze o tratamento direitu... } \\
\text { (8) tá me danu ua, assim uma tristeza que } \\
\text { não sabia queu ia passar por isso aí queu to } \\
\text { passano, queu nunca tomei comprimido, sim } \\
\text { desses comprimido di evita filho, então eu to } \\
\text { sintino assim oh, fatigada, me dá tristeza... } \\
\text { que nem eu, so sozinha, num tem maridu, } \\
\text { num tem relação, num tem nada, eu to } \\
\text { sintino uma coisa bem..., bem triste pra mim. } \\
\text { Que é uma coisa eu pensava queu num ia } \\
\text { passa por isso aí. Purque num so intristida }\end{array}$ & $\begin{array}{l}\text { Não sei se os sintomas orgânicos causam } \\
\text { nervosismo ou se são causados por ele, mas, } \\
\text { a diferença é que estou mais explosiva, mais } \\
\text { irritada, triste, aflita, infeliz, chateada, } \\
\text { aborrecida, perturbada, não tenho mais } \\
\text { aquela paz e acho que tudo isso é devido à } \\
\text { menopausa porque não tinha antes. Acho } \\
\text { que deixam as mulheres aborrecidas, } \\
\text { nervosas, com mal-estar ou aflição. A } \\
\text { insônia, por causa dos calorões, incomoda } \\
\text { também as pessoas com quem a gente } \\
\text { convive e o marido precisa compreender a } \\
\text { situação toda, inclusive sexual, para auxiliar. } \\
\text { Não tenho mais desejo sexual - tenho prazer, } \\
\text { mas não mais aquela vontade como no } \\
\text { começo do casamento, porém, cheguei } \\
\text { perder o prazer de tudo. Pode ser a } \\
\text { medicação conjunta que diminuísse o desejo, } \\
\text { mas com o hormônio também não melhorou. } \\
\text { Não mudou a vida com o marido porque ele }\end{array}$ \\
\hline
\end{tabular}


faze muitas coisa errada, num so de faze e

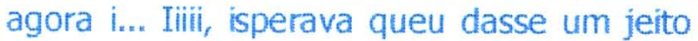
deu melhora, pra mim sinti a .. mais pro final assim da meia idadi, issu sintia mais feliz, purque, seu era tão feliz até agora, agora dispois do poblema de menopausa me dexo desse jeito ai então... eu fiquei meio chatiada. quando é agora to com cosulta marcada dêsdo mes de maio, consegui hoje aqui a cosulta, to desdo meio de maio cuessa cosulta marcada, então..

(9) Achu qui pra mim ta senu um periodu assim muituuu, di muito nervosismu..., queu achu qui não é normal, Fica nervosa assim, as vezes até por nada, então achu qui num ta certu. Qui as vez' a gente qué é dize qui é algum poblema, mas as veiz é poblema da gent' mesmu,

(11) deixa a genti assim..., pareci ner, pareci aborrecidu, não, num contu assim quié nervosu, é aborr ${ }^{\mathrm{e}}$, aborrecimento dentu da genti..,

(12) tinha muita frição

(13) Iii, eu mi sinto muito mal tamém di madrugada, percu sono, pertuba, i a genti fica assim, dá aquele suado, I, da vontadi di levanta, das veiz eu puxo a cuberta, i eu tenho friu eu puxo a cuberta, dali a poco eu sintu calor, eu jogu a cuberta, i viru pra lá, i viru pra cá, Meu maridu fica acomodadu, i fala "Poxa, mais ce dormi", I, mais ié eu qui to $\mathrm{cu}$, cum calorão, cumé qui vo faze...

(14) u nervosismu qui dá, num sei se é pur causa tamém dissu, di nervoso qui dá...

(19) Eu não tenhu apetiti sexual mais. Cabo... Achu qui quanu eu tomu calmante, às vezis quanu tomu calmante ... daí eu num tenhu vontadi. I quanu tava tomanu hormôniu tamém num ajudava...

(24) a única diferença é qui eu to mais ixplosiva... Mais irritada, mais irritada, assimmm, otrus poblema sim eu nuu, nu to tenu....

(25) o sexu já foi diminuindu, num tinha mais vontadi, pra mim si tivessi tudu bem, si num tivessi num tinha mai nada, I daí, já fui uma pessoa mais ..., cabo aqueliss .. prazer di tudu

(27) Sintu bastant' necessidad' di come assim.... Iii, tem mais, dificuldadi di assuntu assim, porque tamem não tenhu vontade de ... manter relação sexual, não, não tenhu. entende e tem um pouco de dificuldade por causa do problema cardíaco. Não esperava que fosse desse jeito porque não sou de fazer coisa errada, então quero dar um jeito de melhorar. Por isso eu resolvi procurar meios de tratamento para chegar na meiaidade mais feliz. No entanto, existem impecilhos, principalmente a demora, para marcar a consulta, os exames e os retornos, dificultando o tratamento e atrasando a resolução dos problemas. 
Essi, essi eu tamém não tenhu não... Não mudo a vida com o marido porque eli também é meiu assim, eli entende, bastant', eli tamém tem um poco de dificuldade por causa do poblema deli,

(28) Quanu começo eu fiquei muntu nervosa, foi quandu começo a monopausa foi quieu fiquei assim ...

(29) Senti assim.. muda completamenti a vida, num sei... Você num tem aqueli, aquela paaz, aquela coisa, ... A genti qué ta beim, de repente, ó brup, muda na hora....

(30) muitu nervosa, eu num mi sintia bem, eu sempri tava assim uma coisa ruim assim, num tava disposta pra nada,... não tinha vontade de nem de faze as coisa ... mias issu foi passandassim por causa qui meu filho começo a fica doenti, e daí eu me dediquei pra eli.. i nunca mais fui.. a procura dooo, dessi tratamentu,

\section{Ancoragens}

\section{$A=\mathrm{A}$ menopausa não é igual ao que todos dizem}

\begin{tabular}{|l|l|}
\hline \multicolumn{1}{|c|}{ EXPRESSÕES-CHAVE } & \multicolumn{1}{|c|}{ DISCURSO DO SUJEITO COLETIVO } \\
\hline (1) Então eu acho que a menopausa nâo ta assim & Eu acho que, para mim, a menopausa não \\
sendo... ah, aquele ficho de cafefa..., aqueli, aquela coisa & está sendo aquela coisa terrivel que todo \\
que todo mundo dĩ que é muito terrivel, aquefa... num to & mundo diz, não é aquele bicho. Não senti os \\
sentindu, não. & calores nem aquelas coisas como as \\
(4) Agora pra mim eu num,.. eu num senti aqueles calor, & mulheres falam. \\
aquefas coisa qui nem as mufher falam, sabi... & \\
\hline
\end{tabular}

\section{$B=$ Todas as mulheres sofrem os sintomas igual a mim}

\begin{tabular}{|c|c|}
\hline EXPRESSÕ̃S-CHAVE & DISCURSO DO SUJEITO COLEIIVO \\
\hline 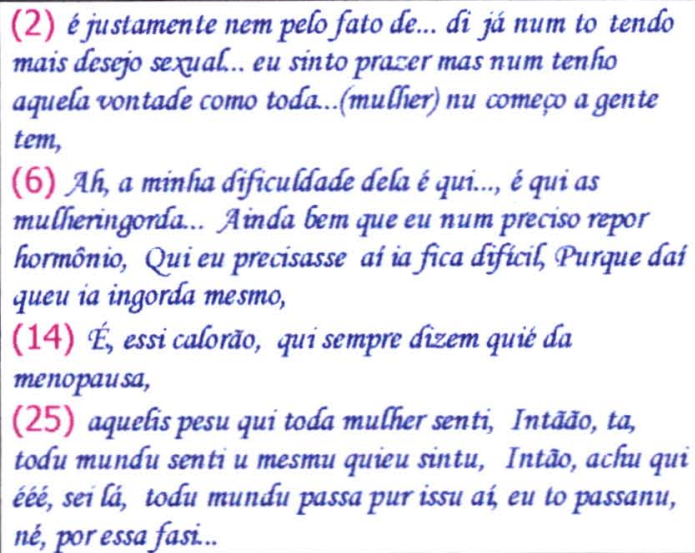 & $\begin{array}{l}\text { Todas as mulheres no começo do casamento } \\
\text { sentem mais desejo sexual que na } \\
\text { menopausa. Porém, engordar e sentir os } \\
\text { calorões sempre dizem ser da menopausa. } \\
\text { Então, eu acho que todo mundo sente as } \\
\text { mesmas coisas que estou sentindo e passa } \\
\text { por essa fase que eu estou passando. }\end{array}$ \\
\hline
\end{tabular}




\section{INSTRUMENTO DE ANÁLISE DO DISCURSO 1}

\begin{tabular}{|c|c|c|}
\hline $\begin{array}{l}\text { EXPRESSÕES - CHAVE Questão } 2 \\
\text { A voz das pessoas revela algo sobre elas, } \\
\text { não é verdade? Fale sobre isso. }\end{array}$ & IDÉIAS CENTRAIS & ANCORAGEM \\
\hline $\begin{array}{l}\text { 1E Bom, acho que as pessoas é... no falá, } \\
\text { nu dia a dia, eu achu que eu consigo } \\
\text { passá pras pessoas... é... demonstrá... } \\
\text { carinho pelas pessoas, demonstrá é... } \\
\text { interesse... quando as pessoas tão com } \\
\text { pobremas, eu procuro ajudá... então eu } \\
\text { sempre uso minha voz por essa, num fico } \\
\text { sem falá, né ... Eu achu que..., a genti ovi } \\
\text { issu. Quanu tava... um ano atrás eu fazia } \\
\text { parte do coral, né... Então a gente... fazia } \\
\text { ensaio, é... a minha... professora disse que } \\
\text { gostava da minha voz, apesar qui eu dizia } \\
\text { que não, mas, eu gostava de cantar, ia lá e } \\
\text { ensaiava dipois a genti... é... cantava, } \\
\text { apesar qui vai cantar prá Jesus, ... } \\
\text { cantora não (rindo) né... No coral assim } \\
\text { não dá pra vê u..., a voz direto, Então, eu } \\
\text { gostava muito... }\end{array}$ & $\begin{array}{l}\text { (1) Ela acha que falando, no } \\
\text { dia a dia, consegue passar, } \\
\text { demonstrar para as pessoas } \\
\text { carinho, interesse. Procura } \\
\text { ajudar falando e usando a voz } \\
\text { quando elas estão com } \\
\text { problemas e que isso é } \\
\text { reconhecido. A } \\
\text { (2) Relata que alguns anos } \\
\text { atrás, apesar dela falar que } \\
\text { não gostava de cantar, sua } \\
\text { professora de coral elogiava } \\
\text { sua voz. Ia aos ensaios e } \\
\text { cantava para Jesus. Acha que } \\
\text { não era cantora porque no } \\
\text { coral não fazia solo, mas } \\
\text { gostava. E }\end{array}$ & \\
\hline $\begin{array}{l}\text { 2E Chi, num sei se da pessoa assim. Num, } \\
\text { tenhu noção no qui que possa mostrá, mas } \\
\text { que muda, muda, no geral... }\end{array}$ & $\begin{array}{l}\text { (1) Não tem noção do que a } \\
\text { voz possa mostrar, apenas } \\
\text { percebe mudanças na voz (ao } \\
\text { longo dos anos) C }\end{array}$ & \\
\hline $\begin{array}{l}\text { 3E Sim, num sei num to ... Sim... me deu } \\
\text { um branco... Falei de mais e agora me deu } \\
\text { branco (rindo)... Estou ficando nervosa de } \\
\text { tudo... Num to sabendo responde a sua } \\
\text { pergunta. Passa pra outra. }\end{array}$ & $\begin{array}{l}\text { Fica nervosa, dá "branco", } \\
\text { porque não está sabendo } \\
\text { responder a pergunta e solicita } \\
\text { que passe para outra. C }\end{array}$ & \\
\hline $\begin{array}{l}\text { 4E Eu concordo... acho que tem as } \\
\text { pessoa, ... que prevalece mais o que eu } \\
\text { gosto.... Ah, acho que elas querem dexá } \\
\text { a gente menos do que elas, entendi? } \\
\text { (rindo)... Pelo tom que elas falam qua } \\
\text { gente... ..Ah, eu acho assim pelo tom...feito } \\
\text { que tem pessoa assim quando ta perto de } \\
\text { só da gente, demostra uma coisa lá, } \\
\text { quando ta perto de otras mais grande, } \\
\text { mostra otra, sabi?... É... eu me sintu } \\
\text { assim... mais arrasada, sabi?... }\end{array}$ & $\begin{array}{l}\text { (1) Concorda que a voz revele } \\
\text { a pessoa. A } \\
\text { (2) Acha que tem pessoas que } \\
\text { prevalecem, que querem } \\
\text { deixar os outros menos que } \\
\text { elas, dependendo de quem } \\
\text { está por perto, pelo tom que } \\
\text { utilizam falando. Sente-se } \\
\text { arrasada quando isso } \\
\text { acontece. D }\end{array}$ & \\
\hline $\begin{array}{l}5 E \text { Eu num achei diferença na minha voz... } \\
\text { Assim, mas tem umas pessoa que a gente } \\
\text { vê que tem diferença. Eu traba...eu } \\
\text { também faço muito... ah, física } \\
\text { (exercícios), né, massagi na garganta. Num } \\
\text { sei si issu ajuda também... purque te ajuda } \\
\text { abrí... canais, né, não dexá trancá a voz, }\end{array}$ & $\begin{array}{l}\text { Não achou diferença na sua } \\
\text { voz. Mas em algumas pessoas } \\
\text { dá para ver a diferença. Ela } \\
\text { faz exercícios, massagem na } \\
\text { garganta, não sabe se isso } \\
\text { ajuda também, mas acha que } \\
\text { abre canais, não deixa trancar }\end{array}$ & \\
\hline
\end{tabular}




\begin{tabular}{|c|c|c|}
\hline $\begin{array}{l}\text {... achu que fica cuidando tamem, } \\
\text { alimentação... não que tivesse que eu } \\
\text { fazé, mas eu sei qué bom, então a genti } \\
\text { obedeci. }\end{array}$ & $\begin{array}{l}\text { a voz. Crê que os cuidados } \\
\text { que tem, mesmo que não } \\
\text { sejam obrigatórios, inclusive } \\
\text { com a alimentação, são bons e } \\
\text { obedece porque auxiliam para } \\
\text { não mudar a sua voz. E }\end{array}$ & \\
\hline $\begin{array}{l}\text { 6E Concordo, concordo. Então, eu acho } \\
\text { que a pessoa conversanu comigo i ali } \\
\text { sintendeno ele já vai vê mais ou menos i } \\
\text { sinti o queu sô.. Eu acfio qui., a pessoa que é } \\
\text { estudado, qui intendí eu achio qui só no conversa a } \\
\text { dotora já vai pega alguma coisa, senfora já vai sinti } \\
\text { afguma coisa diferente em mim.., i dá vai sinti, ai ela } \\
\text { vai fala: ai a senhora acfiu qui num ta bem, pelo quela } \\
\text { me falo qui... }\end{array}$ & $\begin{array}{l}\text { (1) Concorda que a voz } \\
\text { mostra o que a pessoa é. Acha } \\
\text { que se a pessoa conversar } \\
\text { com ela e se entenderem vai } \\
\text { ver e sentir mais ou menos } \\
\text { como ela é. } \\
\text { D }\end{array}$ & $\begin{array}{c}\text { Apenas aquele que } \\
\text { tem conhecimento } \\
\text { formal (estudo } \\
\text { especializado ou } \\
\text { quantidade geral) } \\
\text { consegue opinar } \\
\text { completamente } \\
\text { A }\end{array}$ \\
\hline $\begin{array}{l}\text { 7E Não!! Eu acho qui os olho das pessoa } \\
\text { diz muita coisa, si a pessoa ta falano a } \\
\text { verdade coa senhora, ela tem qui chega e } \\
\text { olha bem nos seus olhos, seja o qui for, } \\
\text { tem que assumi aquilo, tem qui olha bem } \\
\text { pra pessoa, vê quiela ta falando realmente } \\
\text { a verdade....Então eu achu isso, a voz eu } \\
\text { nunca percebi, purque uma qui a gente } \\
\text { num intende muitu... Pa percebe issu... }\end{array}$ & $\begin{array}{l}\text { (1) Discorda. Refere que os } \\
\text { olhos das pessoas mostram se } \\
\text { ela estiver dizendo a verdade, } \\
\text { e que esta deve olhar bem nos } \\
\text { olhos e assumir. A } \\
\text { (2) Acha que não tem } \\
\text { conhecimento para falar a } \\
\text { respeito do assunto, e que } \\
\text { nunca percebeu isso na voz. } \\
\text { D }\end{array}$ & \\
\hline $\begin{array}{l}\text { 8E Eu achu qui sim, purque a genti vê } \\
\text { assim: qui quandu a pessoa ta sintinu } \\
\text { bem, assim sela num ta sintinu mal.. a } \\
\text { pessoa tem um jeitu.. di cunversa, um jeitô } \\
\text { di... fala tudo, i a genti quando não ta si } \\
\text { sintino bem, a genti tem um jeitu deferente } \\
\text { pra cunversa, a genti vê a pessoa que tem } \\
\text { a dificuldade pra cunversa... Vê a veis fala, } \\
\text { a veis senti até pena da tristeza, a genti } \\
\text { senti que a pessoa é mei tristi, meio } \\
\text { aborrecidu..., recramá... essas coisa assim, } \\
\text { eu sei que a pessoa ta sintinu alguma } \\
\text { coisa, i eu já sinti issu aí, purque ieu sinti... } \\
\text { Então eu acho que as pessoa também que ta passanu } \\
\text { pur issu.., faz o memo jeitu quieu to passanu. I issu } \\
\text { ta aparecenu na voz... }\end{array}$ & $\begin{array}{l}\text { (1) Concorda. A } \\
\text { (2) Quando uma pessoa está } \\
\text { se sentindo bem, ela tem um } \\
\text { jeito de conversar, de falar } \\
\text { tudo. E quando não está se } \\
\text { sentindo bem, tem um jeito } \\
\text { diferente de conversar, e os } \\
\text { outros vêem essa dificuldade. } \\
\text { Às vezes as pessoas falam, e } \\
\text { os outros sentem até pena da } \\
\text { tristeza delas. Acha que os } \\
\text { outros sentem que a pessoa é } \\
\text { um pouco triste, aborrecida } \\
\text { porque reclama. Como já se } \\
\text { sentiu assim acha que as } \\
\text { outras pessoas fazem do } \\
\text { mesmo jeito e que aquilo que } \\
\text { está passando aparece na voz. } \\
\text { D }\end{array}$ & $\begin{array}{l}\text { As pessoas agem } \\
\text { igual a mim. } \\
\qquad B\end{array}$ \\
\hline $\begin{array}{l}\text { 9E Acho que até concordo. } \hat{E} \text {, as veiz a } \\
\text { genti cunversanu cua pessoa a genti vê } \\
\text { qui.., olhandu às vez a genti acha assim } \\
\text { qui a pessoa é de uma certa forma... I }\end{array}$ & $\begin{array}{l}\text { (1) Acha que concorda porque } \\
\text { só olhando pode se pensar } \\
\text { que a pessoa é antipática e } \\
\text { chata. }\end{array}$ & \\
\hline
\end{tabular}


cunversanu a gente vê que às vez's num é nada diissu... É uma pessoa boa... I às vezes olhandu pra pessoa a gent' acha assim "Puxa aquela pessoa é antipática... é uma pessoaaa.. muit" chata...", mas no cunversa a gente vê qui num é nada dissu, qui às veiz é uma pessoa muitu booa, então acho qui só conversando qui a genti intendi melhor coa pessoa i vê o que a pessoa é na realidadi... Então acho que a voz da pssoa é, é manda muito, ...É no fala qui a genti vai vê o que a pssoa é...

10E Eu diria quiii ajuda, a dize quem a pessoa é, mais eu acreditu qui a pessoa si mostra o que é através de seus atos, da manera qui si comporta, da manera com que vive, eu creiu qui.. a voz pode ajuda, ma ieu creio qui a manera queu mi comporto fala mais altu.

11E Eu concordu. Ah, eu num sei é queu so meio parada no tempo... Se também quéé, talveis uma coisa assiim, vê os otro cunversanu, tudu, a genti preferi fica.. mais ouvinu qui os oto fala, .... Às veiz num prcuru num entra muito em detaalhe $\operatorname{assim}_{x .}$. E assim queu sei. Uma pessoa qui não é di fala muito podi ser parada nu tempu... Eu creio qui sim. Num sei sé purque é natureza da genti ooo sié aqueli sistema mesmu, num sei, num intend".

\section{E Concordo. Não, eu concordo}

pruquee...tem umas pessoa quee, nu fala Ihi agita, Purque minha fala é muntchu... sei lá, muitu estranha, i agora já otus pela voiz the agrada..., pareci qui pela voiz é... você ...conforma quia pessoa fala muituu, assim um jeitu muitu...conforma muitu você, agora si sua voiz lhim incomoda, eu pensu qui incomoda, Eu sintu qui incomoda, intão... eu acho quee...eu nu meu pensamentu a voiz da pessoa... é muitu bom a pessooa...

$13 \mathrm{E} \vec{E}_{t}$ é mesmu... si a pessoa é nervosu, aleeegre... Ah, às veiz eu cunversu qua vizinha, ela é muitu nervosa... i, intão ieu cunversanu cuessas pessoa, eu mi sintu mal, seu vejo qui ta nervosu, daí eu mi sintu mal, Sintu na voiz da pessoa quiela ta nervosa. I eu tenhu uma nora tamém,

\section{A}

(2) Conversando vê que às vezes não é nada disso, e que as pessoas se entendem melhor e vêem o que o outro é na realidade. Que a voz é um forte índice, porque é no falar que se vê o que a pessoa é.

Discorda apontando que a voz ajuda a dizer o que a pessoa é. Mas acredita que ela só se mostra através dos seus atos, da maneira como se comporta, como vive e que isso é mais importante que a voz. B

(1) Concorda que a voz possa revelar a pessoa.

(2) Acha que se mostra ser parada no tempo. Prefere ficar ouvindo mais e falando menos. E que talvez isso seja da natureza da pessoa ou da educação que teve.

D

(1) Concorda prontamente.

A

(2) Acha que tem pessoas que no jeito de falar deixam os outros agitados, que conforme falam muito ou com um certo jeito a voz incomoda. Acha sua fala muito estranha, mas que tem pessoas que a voz é agradável.

(1) Concorda por meio de um exemplo. A

(2) Relata que às vezes conversa com a sua vizinha e que por ela ser muito nervosa faz com que sinta-se mal. Sente na voz da pessoa que 
ela grita muitu cu filhu... Aquilo mi dexa nuns nervu... principalmenti quando eu vo assim passia na casa deles daí... é terrivel, eu já notu siela ta nervosa... Mi sintu mal...

14E Achu qui curtu concorda... As pessoa antiga sempre fala as coisa verdadera, Como quieu pudia fala isso pra você? Sei lá, num tenhu idéia pra issu aí não. Sei lá, num sei ti explica cume, cumé qui, cumé qui é issu daí.

15E Ai meu Deus num sei sieu entendi... Fala novamente pra mim... Eu achu qui sim... Fiquei sem sabe agora qui... Não sei me expressar assim... Num sei, não...

$16 E$ Podi se qui tenha uma verdade aí no fundu, só quie num cheguei. ... pela voz não, mais assim pelu tom da voiz a genti às vezis percebi si a pessoa ééé agressiiiva, é alterada... Tem uma filha minha quiela assim fala muitu altu, dai já façu assim(faz sinal com a mão para baixo) "menus, menus". É u jeitu dela, intão você já... Iii, tem pssoas qui fala mansinha, tal coisa comu eu falei pra você, na Federação elis atendi e todos elis falam muuitu.. baxiinhu, lá então você se sente aquela energia... Você não se sente bem com quem a pessoa fala muito alto. A genti se irrita... Eu achu qui a genti também não se sente muito bem... qui a genti não gosta muitu de agressividadi. A genti procura assim, eu digu assim pro meu filhu, eli não gosta de muita coisarada assim, eli gosta mais de sussegu, mais de tranqüilidade. Não é de levanta muitu a voz, só quandu eli ta muitu agressivu, quandu ta muitu... Então a genti prucura mesmu a paz..

17E Eu achu qui não, num tem nada a ve, coisa cum otra. Eu achu qui não.

18E Será ? Eu num sei não...A voz da pessoa? Será? Eu num sei não, eu nunca notei issu, nunca percebi.. Num sei não si a voz ... num possu thi dize...

$19 E$ Eu num sei purque num conheçu as pessoa... eu num sei ... ela está nervosa. Sua nora também grita muito com seu neto e quando ela está na casa deles isso faz com que fique muito nervosa $e$ sentindo-se mal. D

Relaciona a questão com dizeres das pessoas mais velhas e, apesar de achar que eles só falam coisas verdadeiras, conclui que não tem conhecimentos para explicar de que forma a voz poderia revelar as pessoas. $C$

Surpreende-se e fica confusa com a questão e acha que não sabe expressar-se para explicá-la.

(1) Concorda, após julgar que tenha um fundo de verdade.

A

(2) Pelo tom de voz pode-se perceber a agressividade, porque fica alterada. Relata sobre sua filha que fala muito forte e que ela solicita que diminua a intensidade, pois pessoas assim irritam os outros porque ninguém gosta de agressividade. $\mathrm{Na}$ Federação (centro espírita) todos falam com pouca intensidade e sente-se muita energia. O seu filho é mais sossegado, mais tranqüilo e só ergue a voz quando está muito agressivo. Acha que, então, eles (sua família) procuram a paz.

Discorda dizendo que não tem nada a ver uma coisa com a outra B

Duvida da questão, pondera e julga não ser capaz de perceber e dizer algo a respeito do assunto. C

Acha que não sabe porque não conhece as pessoas que 


\begin{tabular}{|c|c|}
\hline & dizem isso. C \\
\hline $\begin{array}{l}20 E \text { Eu achu qui não... Agora você me } \\
\text { pego... Eu não mudei nada, continuo, } \\
\text { continuo com a mesma voz i tudu... Não } \\
\text { mudei nada... }\end{array}$ & $\begin{array}{l}\text { Surpreende-se com a questão, } \\
\text { julga que não. Relaciona a voz } \\
\text { com a falta de mudanças em } \\
\text { si mesma. B }\end{array}$ \\
\hline $\begin{array}{l}21 E \text { às veiz u crienti fala "ai eu conheçu a } \\
\text { *** pela voiz, quiela fala calma i } \\
\text { romântica". I eu achu quieu so, purque eu } \\
\text { gostu sempri di trata as pissoa comu si } \\
\text { fossi sim "fala meu bem, fala meu amor, } \\
\text { diga u qui qui ta acontecenu cum você, u } \\
\text { qui você ta pricisanu" daí elis acha qui issu } \\
\text { é românticu... I essi é meu jeitu.. di trata } \\
\text { as pessoas, us amigu, meu filhu... É, tem } \\
\text { hora qui desmonsta u quieu so... I pur tudu } \\
\text { issu tamém às veiz eu tamém falu "ah, eu } \\
\text { conheçu você, ta cum pobema, ce ta } \\
\text { nevosa", purqui issu.. todus falum. Pela } \\
\text { minha voiz, te as pessoa mais íntima minha } \\
\text { sim, qui convivi na mesma casa "ah, to } \\
\text { venu qui a sinhora ta cum argum } \\
\text { pobreminha, qui aconteceu?" Si você... trata } \\
\text { assim a tua voiz ta determinandu, intão } \\
\text { achu quieu so a pessoa... qui na voiz qui us } \\
\text { otru mi conheci... Eu achu qui também meu } \\
\text { ex-maridu, i quanu eu to nevosa quieu ligu } \\
\text { pa eli o eli mi liga eli mi fala "ah, se ta cum } \\
\text { poblema hoji, purque eu to venu qui você } \\
\text { ta... talha ", "não", "não, hoji ce ta, u qui ta } \\
\text { acontecenu?" Eu achu qui a minha } \\
\text { demonstação é da voiz... }\end{array}$ & $\begin{array}{l}\text { (1) Julga a questão } \\
\text { verdadeira: para ela a voz } \\
\text { demonstra o que a pessoa } \\
\text { sente, e determina para os } \\
\text { outros. A } \\
\text { (2) Até os clientes a } \\
\text { reconhecem pela voz calma e } \\
\text { romântica (meiga) que ela } \\
\text { relaciona à sua personalidade } \\
\text { e maneira de tratar as } \\
\text { pessoas, os amigos, o filho, o } \\
\text { ex-marido. Ela percebe na voz } \\
\text { das pessoas se existe algum } \\
\text { problema, e as pessoas mais } \\
\text { intimas a conhecem pela voz. } \\
\text { D }\end{array}$ \\
\hline $\begin{array}{l}22 E \text { Eu achu qui sim porque a pessoa... si } \\
\text { se altera, ela muda de voz, ela responde às } \\
\text { vezi de mau jeitu i tudu, purque si a pessoa } \\
\text { num ta nervosa, si ela ta mais calma ela } \\
\text { responde diferente, então... modifica } \\
\text { mesmu. }\end{array}$ & $\begin{array}{l}\text { (1) Concorda. A } \\
\text { (2) Se a pessoa se altera } \\
\text { muda a voz. Se a pessoa está } \\
\text { nervosa ela responde às vezes } \\
\text { de mau jeito e se estiver } \\
\text { calma responde diferente. D }\end{array}$ \\
\hline $\begin{array}{l}\text { 23E Eu concordu. Concordu porqueee a a } \\
\text { voz... declara u que a pessoa ta sintindu... } \\
\text { Si a pessoa ta tristi, a voiz é du mesmu } \\
\text { jeitu, si ta alegri das veiz é otra... Eu } \\
\text { percebo issu na voiz das pessoa. Entre as } \\
\text {...colega lá da ginástica é assim.... você } \\
\text { senti quandu elas tão tristi, muda } \\
\text { totalmiente.... pela voiz... Inclusive nu } \\
\text { telefoni coa minha nora... Di veiz im } \\
\text { quandu quiela vai fala pra.. cumigu elaaa } \\
\text { "o dona *** purque qui ce ta tristi?", } \\
\text { "cume qui ce adivinho?" "ah, não, a sua } \\
\text { voiz ta borocochô..." Borocochô é aquela }\end{array}$ & $\begin{array}{l}\text { (1) Concorda. A } \\
\text { (2) Acha que a voz declara o } \\
\text { que a pessoa está sentindo. } \\
\text { Se a pessoa está triste a voz é } \\
\text { do mesmo jeito; se está alegre } \\
\text { às vezes é outra. Percebe } \\
\text { essas coisas na voz das } \\
\text { pessoas, nas colegas da } \\
\text { ginástica porque a voz muda } \\
\text { totalmente. Sua nora também } \\
\text { percebe quando ela fica triste } \\
\text { porque fica com uma voz } \\
\text { pequena e triste, demonstrada }\end{array}$ \\
\hline
\end{tabular}




\begin{tabular}{|c|c|c|}
\hline $\begin{array}{l}\text { voizinha tristi.. "öi, dona*** come qui ta? } \\
\text { (em baixa intensidade e velocidade } \\
\text { diminuída), depois ela se alegra e "oi, dona } \\
\text { ***, tudu bem coa sinhora?" Então é aí } \\
\text { quieu veju diferença. É uma voiz mais } \\
\text { clara, mais ativa, quanu ela fala pra dentru } \\
\text { lá, coaquela falta di intusiasmu, a voiz } \\
\text { pausada, aí eu já perguntu "u qui qui ta } \\
\text { havenu aí?" }\end{array}$ & \begin{tabular}{|lr} 
pela baixa & $\begin{array}{r}\text { intensidade e } \\
\text { velocidade rinuída, }\end{array}$ \\
enquanto que na alegria a voz \\
é demonstrada por uma maior \\
velocidade, precisãor e \\
intensidade. Na sua nora \\
percebe a alegria na voz clara, \\
mais ativa; e na tristeza é para \\
dentro, com falta de \\
entusiasmo. Então é aí que ela \\
vê a diferença. D
\end{tabular} & \\
\hline $\begin{array}{l}\text { 24E Eu achu qui sim, purque sieu to } \\
\text { nervosa a minha voz sai diferenti... eu } \\
\text { quase não consigu solta a voz, se to assim, } \\
\text { se eu to bem nervosa, queru fala uma coisa } \\
\text { eu não consigu fala, eu.., choru i num falu. } \\
\text { Noto issu nas pessoas, e as pessoas nota na minfia voz. } \\
\text { Noto, se vê qui a pessoa ta passanu pur } \\
\text { poblema difícil, nessi corredor di hospital di } \\
\text { fisiu, aquelas mulher quieu conversu, eu } \\
\text { veju qui a pessoa ta passanu pela maior } \\
\text { dificuldade i quem num ta...Só pelu jeitu da } \\
\text { pessoa si ixpressa ce já sabi, qui a pessoa } \\
\text { ta passanu pur um períudu difícil... }\end{array}$ & $\begin{array}{l}\text { (1) Concorda que a voz revela } \\
\text { a pessoa. A } \\
\text { (2)Quando está nervosa a dela } \\
\text { sai diferente, quase não } \\
\text { consegue soltar, e se estiver } \\
\text { muito nervosa não consegue } \\
\text { nem falar. Nota isso nas } \\
\text { pessoas e as pessoas notam } \\
\text { na sua voz. Nos corredores do } \\
\text { hospital (onde leva a filha } \\
\text { duas vezes por semana para } \\
\text { fazer sessões de fisioterapia) } \\
\text { fica conversando com as } \\
\text { mulheres e pelo jeito delas se } \\
\text { expressarem sabe se estão } \\
\text { passando por maiores } \\
\text { dificuldades ou não, se } \\
\text { passam por um periodo difícil. } \\
\text { D }\end{array}$ & $\begin{array}{l}\text { As pessoas agem } \\
\text { igual a mim. } \\
\qquad B\end{array}$ \\
\hline $\begin{array}{l}25 E \text { Eu achu qui sim... ... quandu as } \\
\text { pissoas ta bem, achu qui as pessoas deve } \\
\text { di te mais aligria nu conversaaa, di modu } \\
\text { qui ela si senti mais feliz, a felicidade } \\
\text { sempri ta istampadu no rostu das pessoa... } \\
\text { Quanu ta deprimida, ta tristi a pessoa } \\
\text { pareci qui tem medu di conversa, eli fica } \\
\text { iscundidu, si recolhe, que conversa mais } \\
\text { pocu, eu mi sintu assim quanu eu to Gem tristi } \\
\text { eu nu gostu, quenu fica mais nu meu cantinfu assim, só } \\
\text { coaquela pessoa quieu já curti bastanti, dai eu gostu di } \\
\text { conta... mais quandu eu to tristi eu cunversu muitu } \\
\text { pocu, Intão, eu aḉu qui todu mundu é assim, } \\
\text { quandu ta meiu deprimidu, sente a tristeza } \\
\text { já na voiz da pessoa, ... I quanu a pissoa ta } \\
\text { alegre não, eli sorri, eli cunversa bastanti, } \\
\text { fala altu, forti, é pra frenti... }\end{array}$ & $\begin{array}{l}\text { (1) Concorda com a questão. } \\
\text { A } \\
\text { (2) Acha que quando a pessoa } \\
\text { está bem, tem mais alegria na } \\
\text { conversa, no modo dela se } \\
\text { sentir, a felicidade fica } \\
\text { estampada no rosto e na voz, } \\
\text { ela sorri, conversa bastante, } \\
\text { fala alto, forte, pra frente. } \\
\text { Quando está deprimida, triste } \\
\text { a pessoa parece ter medo de } \\
\text { conversar, fica escondida, se } \\
\text { recolhe, conversa pouco, } \\
\text { sente-se a tristeza na sua voz. } \\
\text { Quando ela está triste quer } \\
\text { ficar no seu canto, só com a } \\
\text { pessoa que gosta muito, daí } \\
\text { conta o que se passa, apesar } \\
\text { de falar pouco. D }\end{array}$ & $\begin{array}{l}\text { As pessoas agem } \\
\text { igual a mim. } \\
\text { B }\end{array}$ \\
\hline $\begin{array}{l}\text { 26E Eu achu qui sim. I, caramba, é qui a } \\
\text { gente vê pelu jeitu da pessoa expressa, } \\
\text { assim já nu .... por telefoni é meiu dificil }{ }_{r}\end{array}$ & $\begin{array}{l}\text { (1) Concorda que a voz revele } \\
\text { a pessoa. A } \\
\text { (2) Nota pelo jeito dela se }\end{array}$ & \\
\hline
\end{tabular}




\begin{tabular}{|c|c|c|}
\hline assim pessoalmente é mais fácil. & $\begin{array}{l}\text { expressar. Acha que } \\
\text { pessoalmente é mais fácil de } \\
\text { perceber e no telefone mais } \\
\text { difícil. } \quad \text { D }\end{array}$ & \\
\hline $\begin{array}{l}\text { 27E Pra quem intende eu acfiu qui sim. Tem pissoas } \\
\text { qui estuda bastant... até o comportamento da pessoa } \\
\text { conforme quieu conversa, a pessoa ofhandu pra mim, } \\
\text { efa já safi, aonde quieu to. Eu percebo se tão } \\
\text { alegri, si tão triste pela voz. A voz de uma } \\
\text { pessoa qui ta triste é uma voz assim mais.. } \\
\text { ela nu é solta, ela é mais presa, pra dentru, } \\
\text { a pessoa conversa, mais ela fica insegura, o } \\
\text { intão fica agitada, eu achu qui ta... cum } \\
\text { poblema sériu. Se ta alegre fica diferente, a } \\
\text { genti nota no conversa côa pessoa, } \\
\text { conversa mais... senti alegria, pra conversa } \\
\text { ela é mais solta... }\end{array}$ & $\begin{array}{l}\text { (1) Acha que percebe tristeza } \\
\text { na voz das pessoas porque ela } \\
\text { fica mais presa, para dentro, a } \\
\text { conversa é insegura; ou então } \\
\text { fica agitada, se está com } \\
\text { problema sério. Na alegria é } \\
\text { diferente: a pessoa para } \\
\text { conversar é mais solta. D }\end{array}$ & $\begin{array}{l}\text { Apenas aquele que } \\
\text { tem conhecimento } \\
\text { formal (estudo } \\
\text { especializado ou } \\
\text { quantidade geral) } \\
\text { consegue opinar } \\
\text { completamente } \\
A\end{array}$ \\
\hline $\begin{array}{l}28 \mathrm{E} \text { Eu achu. ...conformi as pessoa } \\
\text { cunversam cua genti, a genti senti quandu } \\
\text { gosta da genti....A genti não si senti beim, } \\
\text { pra genti assim parece qui ta cum raiva da } \\
\text { genti... Eu achu qui é invenção } \\
\text { (imaginação) da genti... }\end{array}$ & $\begin{array}{l}\text { (1) Concorda com a questão. } \\
\text { A } \\
\text { Acha que, conforme a pessoa } \\
\text { conversa, é capaz de mostrar } \\
\text { se gosta do outro, e que não } \\
\text { se sente bem quando parece } \\
\text { que a pessoa está com raiva. } \\
\text { Crê que seja imaginação das } \\
\text { pessoas essa capacidade de } \\
\text { perceber. D }\end{array}$ & \\
\hline $\begin{array}{l}29 \mathrm{E} \text {...É, às vezis, conformi você conversa } \\
\text { côa pessoa, mais o menus intendi, ce vê } \\
\text { comu qui a pessoa é...Conversanu côas } \\
\text { pessoa assim, às veiz ce senti que aquela } \\
\text { pessoa é maau, otru já é mais o menu, otru } \\
\text { já é melhor, um tem idéia melhor ... Quanu } \\
\text { cê vê quié uma pessoa mau, ce si afasta, eu si afastu... } \\
\text { Eu veju qui a pessoa mi agridi, cum } \\
\text { palavra, eu veju qui não é, qui não foi ca } \\
\text { minha cara, eu saio fora... eu num ficu, } \\
\text { num ficu pertu... }\end{array}$ & $\begin{array}{l}\text { (1) Concorda, após hesitar. A } \\
\text { (2) Acha que às vezes } \\
\text { conversando com a pessoa } \\
\text { entende, sente, vê como ela } \\
\text { é: má, mais ou menos ou } \\
\text { melhor, com idéias melhores. } \\
\text { Se ela é má, agride com } \\
\text { palavras, não vai com a cara } \\
\text { dela, acha melhor se afastar, } \\
\text { não ficar perto. D D }\end{array}$ & $\begin{array}{c}\text { As pessoas agem } \\
\text { igual a mim. } \\
B\end{array}$ \\
\hline $\begin{array}{l}\text { 30E Issu depende das pissoas... Si ela ta } \\
\text { falanu a verdadi? Eu percebu. Eu sei quanu } \\
\text { uma pissoa ta mi ingananu, e uma não. ... } \\
\text { eu percebu pela cara da pissoa, não pela } \\
\text { voz, pelo rosto. ...quanu ela ta } \\
\text { mimganandu, pareci qui ela faiz uma cara } \\
\text { bem diferenti. Num sei, eu achu qui na voz } \\
\text { não... u que a pessoa ta sentinu eu } \\
\text { percebu na cara da pissoa. Nu telefoni eu } \\
\text { percebu, falandu pessoalmenti cum certas } \\
\text { pessoas eu percebu. As pessoas percebe } \\
\text { quandu eu num to bem, porque quantas } \\
\text { amigas minha ligam i pedem "u que qui ce } \\
\text { tem? Ce num ta beim?" Daí eu pegu i }\end{array}$ & \begin{tabular}{|l|}
\multicolumn{1}{|c|}{ (1) Discorda. } \\
(2) Relata perceber se as \\
pessoas estão falando a \\
verdade para ela pelo rosto e \\
não pela voz: se estão \\
enganando fazem uma cara \\
diferente. O que a pessoa está \\
sentindo pode ser visto na \\
face. D \\
(3) Porém, concorda que no \\
telefone e pessoalmente com \\
algumas pessoas pode
\end{tabular} & \\
\hline
\end{tabular}


perguntu "porque?" "Não, ta cuma voz diferente.." Ah, quanu a pessoa ta alegri tamem você percebi ... perceber pela voz quando não

está bem ou está alegre. Os outros percebem a sua também. A

\section{INSTRUMENTO DE ANÁLISE DE DISCURSO 2}

Questão 2: A voz das pessoas revela algo sobre elas, não é verdade? Fale sobre isso.

$$
\text { A = Concordam com a afirmação }
$$

\begin{tabular}{|c|c|}
\hline EXPRESSÕES - CHAVE & DISCURSO DO SUJEITO COLETIVO \\
\hline $\begin{array}{l}\text { (1)... no falá, nu dia a dia, é, eu achu qui eu, } \\
\text { que eu consigo passá pras pessoas, é, } \\
\text { demonstrá... carinho pelas pessoas, é } \\
\text { demonstrá é... interesse... quando as } \\
\text { pessoas tão com pobremas, eu procuro } \\
\text { ajudá... então eu sempre uso minha voz por } \\
\text { essa, num fico sem fala, né... } \\
\text { (4) Eu concordo } \\
\text { (6) Concordo, concordo. Então, eu tipo eu, } \\
\text { eu acho que a pessoa conversanu comigo i } \\
\text { ali sintendeno ele já vai vê mais ou menos i } \\
\text { sinti o queu sô.. eu acho isso. } \\
\text { (8) Eu achu qui sim } \\
\text { (9) Acho que até concordo. } \\
\text { (11) Eu concordu. } \\
\text { (12) Concordo. Não, eu concordo } \\
\text { (13) É, é mesmu } \\
\text { (16) Podi se qui tenha uma verdade aí no } \\
\text { fundu, né, só quie num cheguei. ... pela voz } \\
\text { não, mais assim pelu tom da voiz } \\
\text { (22) Eu achu qui sim } \\
\text { (23) Eu concordu. } \\
\text { (24) Eu achu qui sim, } \\
\text { (25) Eu achu qui sim.. } \\
\text { (26) Eu achu qui sim. } \\
\text { (28) Eu achu. } \\
\text { (29)...É, às vezis. } \\
\text { (30) Nu telefoni eu percebu, falandu } \\
\text { pessoalmenti cum certas pessoas eu } \\
\text { percebu. }\end{array}$ & $\begin{array}{l}\text { Pode ser que tenha um fundo de verdade: o } \\
\text { tom de voz faz com que se perceba como o } \\
\text { outro está pessoalmente e até por telefone. } \\
\text { Acho que conversando a gente vai se } \\
\text { entendendo e vê como cada um é. Eu } \\
\text { concordo, porque falando no dia-a-dia eu } \\
\text { consigo demonstrar para as pessoas carinho, } \\
\text { interesse, auxilio quando estão com } \\
\text { problemas. }\end{array}$ \\
\hline
\end{tabular}

$$
\text { B = Discordância da afirmação }
$$

\begin{tabular}{|l|l|}
\hline \multicolumn{1}{|c|}{ EXPRESSÕES - CHAVE } & \multicolumn{1}{c|}{ DISCURSO DO SUJEITO COLETIVO } \\
\hline (7) Não!! Eu acho qui os olho das pessoa diz & Eu acho que não. Agora você me pegou. Eu \\
muita coisa, si a pessoa ta falano a verdade & acho que não tem nada a ver uma coisa com \\
coa senhora, ela tem qui chega e olha bem & a outra - a voz e revelação da pessoa. Na \\
nos seus olhos, seja o qui for, tem que & voz não, mas no rosto. Quando uma pessoa \\
assumi aquilo, tem qui olha bem pra pessoa, & está enganando faz uma cara diferente. Eu \\
vê quiela ta falando realmente a verdade.... & percebo que os olhos da pessoa dizem muita \\
\hline
\end{tabular}


(10) Eu diria quiii ajuda, a dize quem a pessoa é, mais eu acreditu qui a pessoa si mostra o que é através de seus atos, da manera qui si comporta, da manera com que vive, eu creiu qui.. a voz pode ajuda, ma ieu creio qui a manera queu mi comporto fala mais altu.

(17) Eu achu qui não, num tem nada a ve, né, coisa cum otra.Eu achu qui não.

(20) Eu achu qui não... Agora você me pego...

(30) Issu depende das pissoas... Si ela ta falanu a verdadi? Eu percebu. Eu sei quanu uma pissoa ta mi ingananu, e uma não.... eu percebu pela cara da pissoa, não pela voz, pelo rosto. ...quanu ela ta mimganandu, pareci qui ela faiz uma cara bem diferenti. Num sei, eu achu qui na voz não... u que a pessoa eu percebu pela cara da pissoa, não pela voz, pelo rosto. coisa, porque se ela estiver falando a verdade tem que chegar e olhar bem nos seus olhos, assumir aquilo. Eu diria que a voz auxilia a dizer quem a pessoa é, mas são os seus atos, a maneira de se comportar, de viver que fala mais alto.

\section{$\mathrm{C}=$ Considera-se sem conhecimento no assunto}

\begin{tabular}{|c|c|}
\hline EXPRESSÕES - CHAVE & DISCURSO DO SUJEITO COLETIVO \\
\hline $\begin{array}{l}\text { (2) Chi, num sei se da pessoa assim. Num, } \\
\text { num tenhu noção no qui que possa mostra, } \\
\text { (3) Sim, sim, num sei num to ...Sim...me deu } \\
\text { um branco... Falei de mais e agora me deu } \\
\text { branco... Estou ficando nervosa de tudo.. } \\
\text { Num to sabendo responde a sua pergunta. } \\
\text { Passa pra outra. } \\
\text { (14) Achu qui curtu concorda... Como quieu } \\
\text { pudia fala isso pra você? Sei lá, num tenhu } \\
\text { idéia pra issu aí não. Sei lá, num sei ti } \\
\text { explica cume, cumé qui, cumé qui é issu daí. } \\
\text { (15) Ai meu Deus num sei sieu entendi... Fala } \\
\text { novamente pra mim... Eu achu qui sim... } \\
\text { Fiquei sem sabe agora qui... Não sei me } \\
\text { expressar assim... Num sei, não... } \\
\text { (18) Será ? Eu num sei não...A voz da } \\
\text { pessoa? Será? Eu num sei não, eu nunca } \\
\text { notei issu, nunca percebi.. Num sei não si a } \\
\text { voz ... num possu thi dize... } \\
\text { (19) Eu num sei purque num conheçu as } \\
\text { nessoa. eu num sei }\end{array}$ & $\begin{array}{l}\text { Não tenho noção do que a voz possa mostrar } \\
\text { da pessoa. Não sei me expressar e explicar. } \\
\text { Estou ficando nervosa e está me dando um } \\
\text { "branco", não consigo responder sua } \\
\text { pergunta. Não sei, nunca percebi, não notei } \\
\text { que a voz fosse capaz de mostrar o que é a } \\
\text { pessoa e não conheço quem diz isso. }\end{array}$ \\
\hline
\end{tabular}

\section{$\mathrm{D}=$ Experiência leiga com 0 assunto}

\begin{tabular}{|c|c|}
\hline EXPRESSÕES - CHAVE & DISCURSO DO SUJEITO COLETIVO \\
\hline (4) Pelo tom que elas falam qua gente... & Acho que tem pessoas que prevalecem, \\
\hline
\end{tabular}


feito que tem pessoa assim quando ta perto de, só da gente demostra uma.. coisa, quando ta perto de otras mais grande, mostra otra, É..., eu me sintu assim mais arrasada. É issu que eu me sintu.

(8) purque a genti vê assim: qui quandu a pessoa ta sintinu bem, assim sela num ta sintinu mal.. a pessoa tem um jeitu.. di cunversa, um jeito di... fala tudo, i a genti quando não ta si sintino bem, a genti tem um jeitu deferente pra cunversa, a genti vê a pessoa que tem a dificuldade pra cunversa... Vê a veis fala, a veis senti até pena da tristeza, a genti senti que a pessoa é mei tristi, meio aborrecidu..., recramá... essas coisa assim, eu sei que a pessoa ta sintinu alguma coisa, purque ieu sinti, I issu ta aparecenu na voz...

(9) É, as veiz a genti cunversanu cua pessoa a genti vê qui.., olhandu às vez a genti acha assim qui a pessoa é de uma certa forma, I cunversanu a gente vê que às vez's num é nada diissu... É uma pessoa boa,.. I às vezes olhandu pra pessoa a gent acha asssim "Puxa aquela pessoa é antipática... é uma pessoaaa.. muit" chata...", mas no cunversa a gente vê qui num é nada dissu, qui às veiz é uma pessoa muitu booa, então acho qui só conversando qui a genti intendi melhor coa pessoa i vê... o que a pessoa é na realidadi... Então acho que a voz da p ${ }^{\mathrm{e}}$ ssoa é, é manda muito, ...É no fala qui a genti vai vế o que a pssoa é...

(11) Ah, eu num sei é queu so meio parada no tempo... Se também quéé, talveis uma coisa assiim, vê os otro cunversanu, tudu, a genti preferi fica.. mais ouvinu qui os oto fala... Às veiz num prcuru num entra muito em detaalhe assim... Uma pessoa qui não é di fala muito podi ser parada nu tempu... Eu creio qui sim. Num sei sé purque é natureza da genti ooo sié aqueli sistema mesmu, num sei, num intend".

(12) pruquee...tem umas pessoa quee, nu fala Ihi agita... Purque minha fala é muntchu... sei lá, muitu estranha... i agora já otus pela voiz the agrada... pareci qui pela voiz é... você ...conforma quia pessoa fala muituu, assim um jeitu muitu... conforma muitu você, agora si sua voiz lhim incomoda, eu pensu qui incomoda... Eu sintu qui incomoda, intão... eu acho quee...eu nu meu quando estão acompanhadas de outras mais poderosas, querem deixar a gente menor que elas, e isso se percebe pelo tom de voz. Eu me sinto arrasada quando isso acontece. Pelo tom da voz eu percebo também se a pessoa é agressiva, é alterada. Quando a pessoa se altera, ela muda de voz: se está nervosa responde da mau jeito, e se está calma responde diferente, modifica mesmo. Assim, parece que conforme você conversa com a pessoa mais ou menos entende, sente, vê como ela é: má, mais ou menos ou melhor, com idéias melhores. Se ela é má, agride com palavras, se não vai com a minha cara, é melhor me afastar, não ficar perto. Eu converso, às vezes, com a vizinha e sinto na voz que ela está nervosa. A minha nora eu noto porque ela grita muito com o filho e se eu estou na casa deles é terrível, isso me deixa muito nervosa e me sentindo mal. Se estou nervosa a minha voz sai diferente, eu quase não consigo soltar a voz e se estou muito nervosa, não consigo falar, só choro. Eu acho que conforme a pessoa conversa é possivel perceber se gosta da gente, mas não se sente bem com quem parece que está com raiva. Às vezes, olhando uma pessoa a gente acha que ela é antipática,muito chata, mas conversando vemos que não é nada disso, que é uma pessoa muito boa. A gente vê que quando a pessoa está se sentindo bem, tem um jeito de conversar, de falar tudo, e aquela que não está se sentindo bem, tem um jeito diferente, tem dificuldade, é meio triste, meio aborrecida, reclama, e isso aparece na voz. Pode ser também da imaginação da gente ou porque sou meio parada no tempo, preferindo ouvir mais o que os outros falam, sem entrar em muitos detalhes. Não sei se isso é da minha natureza ou se é da educação que tive. Tem pessoas que quando falam deixam os outros agitados. Se é muito 
pensamentu a voiz da pessoa... é muitu bom (13) si a pessoa é nervosu, aleeegre... Ah, às veiz eu cunversu qua vizinha, ela é muitu nervosa, i, intão ieu cunversanu cuessas pessoa, eu mi sintu mal, seu vejo qui ta nervosu, daí eu mi sintu mal... Sintu na voiz da pessoa quiela ta nervosa. I eu tenhu uma nora tamém, ela grita muitu cu filhu... Aquilo mi dexa nuns nervu... principalmenti quando eu vo assim passia na casa deles daí... é terrivel, eu já notu siela ta nervosa... M sintu mal.

(16) a genti às vezis percebi si a pessoa ééé agressiiiva, é alterada... Tem uma filha minha quiela assim fala muitu altu, daí já façu assim(faz sinal com a mão para baixo) "menus, menus". É u jeitu dela, intão você já... Iii, tem pssoas qui fala mansinha, tal coisa comu eu falei pra você, na Federação elis atendi e todos elis falam muuitu.. falam baxiinhu, lá então você se sente aquela energia, Você não se sente bem com quem a pessoa fala muito alto. A genti se irrita... Eu achu qui a genti também não se sente muito

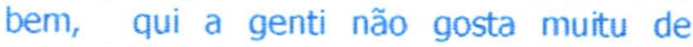
agressividadi. A genti procura assim, eu digu assim pro meu filhu, eli não gosta de muita coisarada assim, sabi, eli gosta mais de sussegu, mais de tranqüilidade. Não é de levanta muitu a voz, só quandu eli ta muitu agressivu, quandu ta muitu... Então a genti prucura mesmu a paz...

(21) às veiz u crienti fala "ai eu conheçu a **** pela voiz, quiela fala calma i romântica". I eu achu quieu so, purque eu gostu sempri di trata as pissoa comu si fossi sim "fala meu bem, fala meu amor, diga u qui qui ta acontecenu cum você, u qui você ta pricisanu" dai elis acha qui issu é românticu..

I essi é meu jeitu.. di trata as pessoas, us amigu, meu filhu... É, tem hora qui desmonsta u quieu so... I pur tudu issu tamém às veiz eu tamém falu "ah, eu conheçu você, ta cum pobema, ce ta nevosa", purqui issu.. todus falum. Pela minha voiz, te as pessoa mais intima mminha sim, qui convivi na mesma casa "ah, to venu qui a sinhora ta cum argum pobreminha, qui aconteceu? ? $^{r}$ Si você.. trata assim a tua voiz ta determinandu, intão achu quieu so a pessoa.. qui na voiz qui us otru mi conheci... Eu achu qui também meu ex-maridu, purque estranha, eu sinto que incomoda. Parece que a voz, conforme a pessoa fala muito ou assim de um certo jeito, incomoda. A minha filha fala muito forte, é o jeito dela, mas eu já faço sinal para diminuir. Ninguém se sente bem com uma pessoa que fala assim; a gente se irrita, não se sente bem porque não gosta de agressividade. Eu digo para os meus filhos que a gente procura a paz. E agora outros têm a voz que agrada. Algumas pessoas falam mansinho e dão muita energia. Várias dizem que conhecem a minha voz porque ela é calma e romântica. E acho que eu sou assim porque eu gosto de tratar bem as pessoas, os amigos, o filho, o ex-marido, esse é o meu jeito. Os mais íntimos, pela minha voz percebem se estou com algum probleminha, mesmo que eu não queira demonstrar. Eu também percebo se estão com problema ou nervosos. Eu acho que a minha demonstração é na voz. Eu percebo isso na voz das pessoas, na forma de se expressar. Entre as colegas você sente pela voz quando elas estão tristes, muda totalmente. As mulheres com quem converso eu vejo se estão passando ou não por maior dificuldade, por um período difícil. Então, eu vejo diferença: a voz alegre é mais clara, mais ativa; e a voz triste é para dentro, falta entusiasmo, é pausada. Quando a pessoa está alegre ela sorri, conversa bastante, fala alto, forte e para frente. Eu acho que quando as pessoas estão bem elas têm mais alegria na conversa, de modo que ela se sente mais feliz, com a felicidade estampada no rosto e na voz. Quando está deprimida, triste, a pessoa parece que tem medo de conversar, fica escondido, se recolhe, conversa pouco. Eu percebo se estão alegres ou tristes pela voz. A pessoa triste ela não é solta, é mais presa, para dentro, a conversa é insegura ou mais agitada, eu acho que está com problema 
a genti foi casadu i convivi há vintii seti anu, i quanu eu to nevosa quieu ligu pa eli o eli mi liga eli mi fala "ah, se ta cum poblema hoji, purque eu to venu qui você ta.. talha ", "não", "não, hoji ce ta, u qui ta acontecenu?" Eu achu qui a minha demonstação é da voiz...

(22) porque a pessoa... si se altera, ela muda de voz, ela responde às vezi de mau jeitu i tudu, purque si a pessoa num ta nervosa, si ela ta mais calma ela responde diferente, então... modifica mesmu.

(23) a voz .. declara u que a pessoa ta sintindu, ... Si a pessoa ta tristi, a voiz é du mesmu jeitu, si ta alegri das veiz é otra, Eu percebo issu na voiz das pessoa. Entre as ..colega lá da ginástica é assim.... você senti quandu elas tão tristi, muda totalmiente.... pela voiz... Inclusive nu telefoni coa minha nora... Di veiz im quandu quiela vai fala pra.. cumigu elaaa "o dona $* * *$ purque qui ce ta tristi?", "cume qui ce adivinho?" "ah, não, a sua voiz ta borocochô..." Borocochô é aquela voizinha tristi.. "öi, dona*** come qui ta?' (em baixa intensidade e velocidade diminuída), depois ela se alegra e "oi, dona ***, tudu bem coa sinhora?" (aumenta a velocidade, a precisão e a intensidade) Então é aí quieu veju diferença. É uma voiz mais clara, mais ativa, é issu memu, quanu ela fala pra dentru lá, coaquela falta di intusiasmu, a voiz pausada, aí eu já perguntu "u qui qui ta havenu ai?"

(24) purque sieu to nervosa a minha voz sai diferenti... eu quase não consigu solta a voz, se to assim, se eu to bem nervosa, queru fala uma coisa eu não consigu fala, eu..., choru i num falu. Noto, se vê qui a pessoa ta passanu pur poblema difícil, nessi corredor di hospital di fisiu, aquelas mulher quieu conversu, eu veju qui a pessoa ta passanu pela maior dificuldade i quem num ta...Só pelu jeitu da pessoa si ixpressa ce já sabi, qui a pessoa ta passanu pur um periudu difícil...

(25) ... quandu as pissoas ta bem, achu qui as pessoas deve di te mais aligria nu conversaaa, di modu qui ela si senti mais feliz, a felicidade sempri ta istampadu no rostu das pessoa...Quanu ta deprimida, ta tristi, a pessoa pareci qui tem medu di conversa, eli, fica iscundidu, si recolhe, que sério. Se está alegre fica diferente, a conversa tem mais alegria, é mais solta. No telefone, algumas pessoas amigas percebem quando algo não está bem, ou quando se está alegre, porque fica com uma voz diferente. A minha nora percebe quando estou triste e diz que a voz está borocoxô, que é a quela vozinha triste. Com algumas pessoas é mais difícil perceber, pessoalmente fica mais fácil. Então, eu acho que só conversando entendemos melhor e vemos o que a pessoa é na realidade e que a voz está determinando 0 que os outros conhecem. A voz declara o que a pessoa está sentindo, a voz é quem manda: é no falar que a gente vê o que a pessoa é. 
conversa mais pocu, eu mi sintu assim sabi, quanu eu to bem tristi eu nu gostu, queru fica mais nu meu cantinhu assim, só coaquela pessoa quieu já curti bastanti, daí eu gostu di conta, sabi, mais quandu eu to tristi eu cunversu muitu pocu, sabi... Intão, eu achu qui todu mundu é assim, quandu ta meiu deprimidu, sente a tristeza já na voiz da pessoa, ... I quanu a pissoa ta alegre não, eli sorri, eli cunversa bastanti, fala altu, forti, é pra frenti, né...

(26) I, caramba, é qui a gente vê pelu jeitu da pessoa, expressa, assim já nu .... Ah, sim, por telefoni é meiu difícil, assim pessoalmente é mais fácil.

(27) Eu percebo se tão alegri, si tão triste pela voz. A voz de uma pessoa qui ta triste é uma voz assim mais.. ela nu é solta, ela é mais presa, pra dentru, a pessoa conversa, mais ela fica insegura, o intão fica agitada, eu achu qui ta... cum poblema sériu. Se ta alegre fica diferente, a genti nota no conversa côa pessoa, conversa mais... senti alegria, pra conversa ela é mais solta...

(28) ...conformi as pessoa cunversam cua genti, a genti senti quandu gosta da genti....A genti não si senti beim, pra genti assim parece qui ta cum raiva da genti... Eu achu qui é invenção (imaginação) da genti,

(29) conformi você conversa côa pessoa, mais o menus intendi, ce vê comu qui a pessoa é...Conversanu côas pessoa assim, às veiz ce senti que aquela pessoa é maau, otru já é mais o menu, otru já é melhor, um tem idéia melhor, eu ... Quanu cê vê quié uma pessoa mau, ce si afasta, eu si afastu... Eu veju qui a pessoa mi agridi, cum palavra, eu veju qui não é, qui não foi ca minha cara, eu saio fora... eu num ficu, num ficu pertu... (30) As pessoas percebe quandu eu num to bem, porque quantas amigas minha ligam i pedem "u que qui ce tem? Ce num ta beim?" Dai eu pegu i perguntu "porque?" "Não, ta cuma voz diferente.." Ah, quanu a pessoa ta alegri tamem você percebi ...

\section{$\mathbf{E}=$ Experiência profissional com $\mathrm{o}$ assunto}

\section{EXPRESSÕES - CHAVE}

DISCURSO DO SUJEITO COLETIVO (1) Quanu tava... um ano atrás eu fazia Há um ano atrás eu fazia parte do coral. \begin{tabular}{llll} 
parte do coral... Então a gente... fazia Havia ensaios e a professora gostava da \\
\hline
\end{tabular} 
ensaio, é... a minha... professora disse que gostava da minha voz, apesar qui eu dizia que não, mas, eu gostava de cantar, ia lá e ensaiava dipois a genti... é... cantava, apesar qui vai cantar prá Jesus... Cantora não... No coral assim não dá pra vê a voz direto...

(5) Eu traba...eu também faço muito... física (exercícios), massagi na garganta. Num sei si issu ajuda também.... purque te ajuda abri.., canais, não dexa tranca a voz, achu que muda purque eu fico cuidando tamem... alimentação.... não que tivesse que eu faze, mas eu sei qué bom, então a genti obedeci. minha voz. Não que eu fosse cantora porque em um coral não dá para ouvir a voz individual. Eu faço exercícios e massagem na garganta para não trancar a voz e cuido da alimentação porque eu sei que é bom e obedeço.

\section{Ancoragens \\ $A=$ Apenas aquele que tem conhecimento formal (estudo especializado ou quantidade geral) consegue opinar completamente}

\begin{tabular}{|c|c|}
\hline EXPRESSÕES - CHAVE & DISCURSO DO SUJEITO COLEIIVO \\
\hline $\begin{array}{l}\text { (6) Eu acho qui., a pessoa que é estudado, qui intendi, eu } \\
\text { acho qui só no conversa a dotora já vai pega alguma coisa, } \\
\text { sen hora já vai sinti alguma coisa diferente em mim.., } \\
\text { (27) Pra quem intende eu achu qui sim. Tem pissoas qui } \\
\text { estuda bastanti... até o comportamento da pessoa conforme } \\
\text { quieu conversa, a pessoa ofhandu pra mim, ela já sabi, } \\
\text { aonde quieu to }\end{array}$ & $\begin{array}{l}\text { Eu acho que quem estudou pode entender o } \\
\text { que a voz revela da pessoa e vai peceber se há } \\
\text { alguma coisa diferente, que não está bem, } \\
\text { conforme conversar. }\end{array}$ \\
\hline
\end{tabular}

\section{$B=$ As pessoas agem igual a mim}

\begin{tabular}{|c|c|}
\hline EXPRESSÕES - CHAVE & DISCURSO DO SUJEITO COLEITVO \\
\hline $\begin{array}{l}\text { (8) Então eu acho que as pessoa também que ta passanu } \\
\text { pur issu.., far o memo jeitu quieu to passanu. } \\
\text { (24) Noto issu nas pessoas, e as pessoas nota na min fia } \\
\text { voz. } \\
\text { (25) quanu eu to bem tristi eu nu gostu, queru frica mais } \\
\text { nu meu cantinfiu assim, só coaquela pessoa quieu já curti } \\
\text { bastanti, dai eu gostu di conta.. mais quandu eu to tristi } \\
\text { eu cunversu muitu pocu, Intão, eu achu qui todu mundu é } \\
\text { assim, } \\
\text { (29) Quanu cê vê quié uma pessoa mau, ce si afasta, eu si } \\
\text { afastu... }\end{array}$ & $\begin{array}{l}\text { Acho que da mesma forma que eu noto nas } \\
\text { pessoas questões relacionadas à voz, elas } \\
\text { notam em mim. Agem da mesma maneira que } \\
\text { eu: quando passam por problemas ficam triste, } \\
\text { conversam pouco e se afastam das pessoas } \\
\text { que demonstram maldade no tom de voz. }\end{array}$ \\
\hline
\end{tabular}

\section{INSTRUMENTO DE ANÁLISE DO DISCURSO 1}

\begin{tabular}{|l|l|l|}
\hline EXPRESSÕES - CHAVE Questão3 & IDÉIAS CENTRAIS & ANCORAGEM \\
E a sua voz? Fale um pouco sobre ela. & & \\
\hline 1E Bom, eu tenho uma voz é... eu achu & (1) Ela acha que tem uma voz & \\
que ela é um tom..., suave, né... eu fazia & com um tom suave. Era & \\
parte do soprano, né... Então uma voz & soprano, uma voz que & \\
\hline
\end{tabular}


bastante aguda, assim a gente eleva bastante, né ... Segurando o, contralto i a.... tenor, né ... Então, a gente conseguia, i eu conseguia fazê essa part ${ }^{e} \ldots$. mais eu tava com a pressão muito alta i..., comecei a me sentir exageradamente gorda, senti muito cansaço ... pelo meu trabalho qui é agitado, eu já chegava lá super cansada, né..., Já chegava cansada... i... depois eu fui deixanu, né... Pedi licença, mais eu pretendo voltá, porque eu gostu muito de fazê alguma coisa prá... porque através dus hinu, né, da mensagem que a gente passa pas pessoas, então tem pessoas que ta com poblemas e ouvindo, né... As vezes faz muito bem pras pessoas ... Muitas vezis, quantas vezes já... a gente se apresentó... fim de ano assim no Natal, cantata de Natal, né.... Então, as pessoas paravam e dizia "oh é muito bonito o que vocês tão fazendo", aquela coisa toda... Então... passo até no jomal, o coral das senhoras... té eles falaram da terceira idade, qui bom qui eu já faço parte da terceira idade (rindo)... Não, mais estava juntu, né... é uma coisa assim, é muito gratificante, sabe du dia a dia, aquela coisa toda, sabi ... e issu no geral, ...é uma coisa ajuda você, é ... aumenta tua fé, né... pelo modo que você...ta ali fazendo aquele trabalhu, ensaiandu, dedicandu, porque... é a obra que tem que fazé, né.... e é um modu de prega... o evangelho pras pessoas, né...

2E Ah, eu acho que já... a voz da gente já muda de assim... fica mais grossa, já num fica aquela voz mais suave, né?... Purque... a gente nota pelo falá já, fica mais ROCA, achu que em todos os aspecto, né... Tanto pra falá, como pra cantá... É, eu num tinha a voz assim roca como eu tenhu agora... Eu não tinha a voz assim, minha voz era um poco mais... num veju tantu assim no no fala assim, fica mais mais presa... Eu num tinha a voz assim, minha voz era mais... limpa, e hoje já ta mais... Ah, eu sintu assim comu si... na garganta alguma coisa prendesse na hora de falá, eu to falando com você assim, eu sinto que aqui na garganta parece que prende na hora de falá, antigamente não. Soltava a voz mais, não tinha essa considera bastante aguda, elevada, que segurava o contralto e o tenor. A

(2)Conseguia fazer essa parte, mas estava com a pressão muito alta, se sentindo exageradamente gorda, cansada. Talvez pelo seu trabalho que é agitado, chegava cansada (para ensaiar), foi deixando e pediu licença. E

(3) Porém, quer voltar, porque por meio das mensagens dos hinos pode ajudar as pessoas que estão com problemas. Muitas vezes, no fim das apresentações das Cantatas de Natal, as pessoas paravam e elogiavam. Saiu no (tele)jornal como se fosse - coral das senhoras da terceira idade. Então, sente-se gratificada, no dia-a-dia aumenta sua fé, pelo modo que faz o trabalho ensaiando, dedicando e pregando o evangelho para as pessoas, mediante o canto. C

(1) Supõe que a voz muda, fica mais grossa, já não é mais uma voz suave. Nota para falar e para cantar a sua ficou mais rouca, mais presa, mais grossa. Sente como se na garganta alguma coisa prendesse na hora de falar. Antigamente não, a voz era mais limpa, soltava mais, não tinha essa rouquidão, não ficava essa coisa presa. B

(2) Acha que a mudança ocorreu devido a menopausa. A maioria das pessoas fala que muda o comportamento
A maioria diz que a menopausa muda a vida da gente. 
roquidão, essa... coisa presa pra conversá, qui a gente falandu prende, né?... antigamente eu sentia qui ... soltava mais a voz... era mais fácil, a fala... mais limpa... num ficava aquela coisa presa... V- e hoje não, hoje tem mais roca, mais grossa, engrossó mais a voz. Eu não tinha essa voz grossa... Eu achio que é devido a menopausa... ^ Eu acho que sim, né? '́, maioria das pessoas falam, né... que muda u comportamentu, muda a voiz, muda... (rindo) Comportamento queu digo na vida sexual da gente, né... Você já não é a mesma coisa...né? Você já não sente aquela, aquele entusiasmu que uma mulher recém casada quando ela é nova, quela sente... Eu senti a diferença da minha vida sexual pra cá. Já não é queli entusiasmu mais ... Não sei se é devidu a menopausa também ou é... cansaço físico também que faz dormi, mudá, né... Mas eu acredito que sim, que seja mais pelu fatu da menopausa.

3E Minha voz é grossa i é feia, é isso? (rindo)... eu achu feia, eu não gosto da minha voz, fala grossa, parece di homi... Foi engrossando a voz, faz cincu, seis anus...

4E O qui que eu vô falá, num sei ...., eu... (1) acho que minha voz é... (rindo) normal assim, sabi?... ah, se eu to num... tá se sentindu bem, fala as coisa bonita, acho isso aí... eu num sei. > É que se a gente é estudada, acho que sabe fala milhor, né, e isso como eu nunca fui... sei lá, assim... não por não ter ido no colégio, achu que eu num tinha cabeça, sab'... eu me esqueço de todas as coisa que eu faço, sempre assim... as veiz me lembro de dá um recado, às veiz mi esqueçu... Que nem meus remédio, to pensando que eu num sei dize o nome pra dotora que remédio queu tomo, pra pressão, essas coisa... fico ali, leio, pegando, mas depois quando chego eu num sei...

5E Quantu mais velhu, poderá parece... Eu tava te falanu queu tenho a voz tão forte, que quando puxava o canto na igreja, na minha comunidade, ele.. eu puxei tão alto, tanto que o padre que tava celebrando, pego e boto a mão nos óculos i falo i riu... Diz: mas ela quande abre a boca pra sexual, que já não se é mais a mesma coisa, que não se sente o entusiasmo de uma mulher recém-casada, quando é nova, e que muda a voz. Sentiu diferença na vida sexual, menos entusiasmo. Confere mais peso à menopausa. D

(3) Mas considera o cansaço físico que a faz dormir. E
Considera sua voz grossa e feia, não gosta dela, parece de homem. Foi engrossando há mais ou menos cinco, seis anos.

(1)Julga que

pessoas estudadas sabem explicar melhor. Mas observa que a sua é uma voz normal: se está se sentindo bem, fala coisas bonitas.

(2) Relata que tem dificuldades com sua memória: não foi ao colégio por isso, esquece de dar recados ou do nome dos remédios que toma para pressão, por exemplo. E

(1) Reconhece que sua voz é tão forte que quando cantava na igreja da sua comunidade, até o padre que celebrava dizia que precisava cuidar dos óculos (para não quebrar as lentes com o som). Uma 


\begin{tabular}{|c|c|c|}
\hline $\begin{array}{l}\text { canta.. sai, cuida do meus óculos. E a } \\
\text { minha amiga que tava durmindu... diz que } \\
\text { se acordo com a minha voz. Num dava } \\
\text { muito di ajuda, mas tu me acordo na hora } \\
\text { de canta ... Realmente eu tenho a voz bem } \\
\text { forte.... e ai eu sempre procuru trabalha } \\
\text { ela... abri bem a garganta, solta bem a voz, } \\
\text { i pur assim, te agora se sainu bem. }\end{array}$ & $\begin{array}{l}\text { amiga que estava dormindo } \\
\text { acordou com seu canto. A } \\
\text { (2) Procura trabalhar a voz } \\
\text { abrindo bem a garganta e } \\
\text { soltando o som. Por isso acha } \\
\text { que tem se saído bem. D } \\
\text { (3) Contudo, compreende que } \\
\text { quando estiver mais velha } \\
\text { poderá aparecer mudanças. } \\
\text { E }\end{array}$ & \\
\hline $\begin{array}{l}6 \text { 6E ... a minha voz acho qui num mudo } \\
\text { nada, desde quiii, eu mim tendo por vó... } \\
\text { Já so vó quatorze vezes... iii, eu acho que a } \\
\text { minha voz continua a mesma, igual, muitas } \\
\text { pessoa falo qui. quando entra na menopausa a voz } \\
\text { muda também... Fala qui a voz muda mais } \\
\text { grossa..., sei lá, fica cum voz di home... } \\
\text { cria mais pêlo, eu ackio eu num to com nenhum } \\
\text { dessis problema ainda... Pode se que vai vim... A voz } \\
\text { minha continua a mesma..., eu to do } \\
\text { mesmu jeitu. A minha voz é um poco } \\
\text { aguda eu acho. Num sei se acha, mais tem } \\
\text { veizes queu é, assim, deu fala... eu falo } \\
\text { assim um poco ardido... um jeito assim } \\
\text { engraçado, Eu achu, num sei i..., é eu já } \\
\text { ouvi minha voz, eu já gravei já ouvi, falei " } \\
\text { Nossa Senhora D'Aparecida num é ieu qui } \\
\text { to falanu aqui, é outra pessoa", purque tá } \\
\text { muito fea essa voz, i hoji eu to qua voz } \\
\text { meia estranha purque eu to qua garganta } \\
\text { um poco dueno... mais... quando eu gravo } \\
\text { eu morro dá risada, de vê minha vaz no } \\
\text { gravador... purque eu acho tão } \\
\text { engraçada, é uma voz assim muita } \\
\text { aguda..., estalada... Então, i eu so meio } \\
\text { poco rápida pra fala... Então, nossa, pareci } \\
\text { uma matraca falano... }\end{array}$ & $\begin{array}{l}\text { (1) Pondera que sua voz não } \\
\text { mudou nada, continua a } \\
\text { mesma até agora, mesmo } \\
\text { sendo avó de quatorze netos. } \\
\text { Acha que sua voz é um pouco } \\
\text { aguda, ardida, com jeito } \\
\text { engraçado. Não se reconhece, } \\
\text { por ser muito feia, como se } \\
\text { fosse de outra pessoa, } \\
\text { engraçada, muito aguda, } \\
\text { estalada, muito rápida, } \\
\text { parecendo uma matraca } \\
\text { quando fala. B } \\
\text { (2) Muitas pessoas dizem que } \\
\text { na menopausa a voz } \\
\text { engrossa, fica igual à de } \\
\text { homem, cria pêlo, mas acha } \\
\text { que não está com nenhum } \\
\text { desses problemas. Supõe que } \\
\text { ainda possam aparecer. } \\
\text { D }\end{array}$ & $\begin{array}{c}\text { A maioria diz que a } \\
\text { menopausa muda a } \\
\text { vida da gente. } \\
\text { A }\end{array}$ \\
\hline $\begin{array}{l}\text { 7E Minha voz num ta aquela coisa } \\
\text { perfeita... Pior é qui eu num sei a palavra } \\
\text { pra dize como qui é a minha voz..., Eu } \\
\text { acho minha voz é um poco roca de uns } \\
\text { anos pra cá, num é mais uma voz limpa qui } \\
\text { nem era antigamente... É um poco mais } \\
\text { roca. Antes ela era uma voz mais limpa, } \\
\text { antes uns trinta anos pra cá eu acho, trinta } \\
\text { anos atrás agora, dos vinte anos pra cá } \\
\text { quela mudo um poco, num sei se é pur } \\
\text { causa da menopausa... mas menopausa } \\
\text { mesmo quieu to fazeno tratamento, purque }\end{array}$ & $\begin{array}{l}\text { (1) Verifica que sua voz não } \\
\text { é perfeita, que está um pouco } \\
\text { rouca de uns anos para cá, } \\
\text { não é mais limpa como era } \\
\text { antigamente. } \\
\text { B } \\
\text { (2) Sentiu diferença há uns } \\
\text { trinta ou vinte anos antes e } \\
\text { mais ainda há uns quatro } \\
\text { anos e não sabe dizer se é em } \\
\text { função da menopausa porque }\end{array}$ & \\
\hline
\end{tabular}




\begin{tabular}{|c|c|}
\hline $\begin{array}{l}\text { eu tomava aquela injeção Denitriu, que } \\
\text { agora ela ta proibida.... Eu tinha voz mais } \\
\text { limpa uns quatro anos pra trás, agora de } \\
\text { um tempo pra cá eu já noto qui é um poco } \\
\text { roca... }\end{array}$ & $\begin{array}{l}\text { tomava uma injeção } \\
\text { (hormônio??) que agora é } \\
\text { proibida. }\end{array}$ \\
\hline $\begin{array}{l}8 \mathrm{E} \text { A minha voz, se eu tive bem nervosa, } \\
\text { qui nem eu sintu quandu eu veju queu to } \\
\text { nervosa pur causa de pobrema, eu sinto qui } \\
\text { minha voz modifica um poco... o cunversu } \\
\text { alto dimais, o cunversu baxo dimais. }\end{array}$ & $\begin{array}{l}\text { Percebe que a sua voz se } \\
\text { modifica um pouco se estiver } \\
\text { muitor nervosa. } \\
\text { Conversa alto (forte) ou baixo } \\
\text { (fraco) demais. C }\end{array}$ \\
\hline $\begin{array}{l}\text { 9E Eu adoro a minha voz... Mas num sei o } \\
\text { que que de repenti as pessoa acha... De } \\
\text { repent' a pessoa.. ah, vai conversa cua } \\
\text { genti ii, num acha assim quii... ...Mas eu } \\
\text { ainda achu qui as pessoa gosta, é. Achu qui } \\
\text { é um tant }{ }^{\prime \prime} \text { suave..., é assim quieu achu. }\end{array}$ & $\begin{array}{l}\text { Considera a sua voz um tanto } \\
\text { suave e gosta muito dela. Não } \\
\text { sabe se as pessoas gostam e } \\
\text { percebem igual a ela, mas crê } \\
\text { que sim. } \\
\text { A }\end{array}$ \\
\hline $\begin{array}{l}\text { 10E É dificil dize... Como é a minha voz? ... } \\
\text { eu poderiaaa fala alguma coisa, i de repenti } \\
\text { ela si torna irritanti, a minha voz, pra mim } \\
\text { mesmo, dependenđu a manera com qui eu } \\
\text { falu, a, a forma quieu falu..., Muitas vezes } \\
\text { eu posso grita, aí eu to mi tornanu irritanti } \\
\text { pra mim mesmu, agora... tem várias } \\
\text { maneras di si fala, i eu tenhu aprendidu } \\
\text { quiii seu fala brandu, seu fala com amor... } \\
\text { quas pessoas, eu ganhu muitu mais... eu } \\
\text { creiu quiii, com a minha voz, qua minha } \\
\text { fala, eu possuuu demonstra amor pelas } \\
\text { pessoas, qua minha voz eu possuuu, } \\
\text { aconselhar ou intão falar às pessoa aquilo } \\
\text { qui.. elas necessitam ouvir de repenti, } \\
\text { quelas tão passanu por algum problema, } \\
\text { então com a minha voz eu posso faze } \\
\text { muita coisa... Eu posso até tira uma vida de } \\
\text { repenti lá qui ta nu fundu... nu buracu, com } \\
\text { a minha voz eu possu chamá-la, possu } \\
\text { traze ela di volta à vida... }\end{array}$ & $\begin{array}{l}\text { (1) Acha difícil dizer, porque } \\
\text { conforme o que fala, ou da } \\
\text { forma como fala pode tornar- } \\
\text { se irritante, como no grito. } \\
\text { Tem aprendido que se falar } \\
\text { brando e com amor, as } \\
\text { pessoas e ela ganham com } \\
\text { isso. A } \\
\text { (2) Então crê que com sua } \\
\text { voz/fala possa, por exemplo, } \\
\text { demonstrar amor, aconselhar } \\
\text { ou falar o que as pessoas } \\
\text { necessitam ouvir por estarem } \\
\text { passando por problemas, } \\
\text { pode fazer muita coisa, até } \\
\text { tirar uma pessoa que está no } \\
\text { fundo do buraco e chamá-la } \\
\text { de volta à vida. } \\
\text { c }\end{array}$ \\
\hline $\begin{array}{l}11 \mathrm{E} . . . \text { eu creiu qui é bão... Purque eu } \\
\text { cunsigu fala direitu... }\end{array}$ & $\begin{array}{l}\text { Crê que a voz seja boa porque } \\
\text { consegue falar direito. A }\end{array}$ \\
\hline $\begin{array}{l}\text { 12E Ah, eu mesma nem noto... Eu noto } \\
\text { assim: agora depois da tiróidi eu fiquei } \\
\text { roca, fiquei muito deferente purque nois } \\
\text { somo evagello, qui nois gosta di canta, } \\
\text { intão minha voiz roco, eu fui...eu cantava } \\
\text { muito bem assim... depois eu achei } \\
\text { estranha a minha voiz, eu achei muito } \\
\text { deferente, fiquei roca. Já tem uma base } \\
\text { duns... seis anus mais o menus queu to } \\
\text { assim. Só qui agora eu to bem roca pur } \\
\text { causa da gripe forht }{ }^{\dagger} . . . \text { mais a minha voiz }\end{array}$ & $\begin{array}{l}\text { (1) Não nota muito, ficou } \\
\text { rouca, diferente. É evangélica } \\
\text { e gosta muito de cantar, } \\
\text { cantava bem e há uns seis } \\
\text { anos percebeu que ficou } \\
\text { estranha, diferente, tapada e } \\
\text { rouca. B } \\
\text { (2) Não associa à menopausa } \\
\text { porque está sem menstruação } \\
\text { há um ano e seis meses e não } \\
\text { percebeu diferença, mas à }\end{array}$ \\
\hline
\end{tabular}




\begin{tabular}{|c|c|}
\hline $\begin{array}{l}\text { tapo muito depois da tiróide...Ta cum ano } \\
\text { e seis meis que to sem menstruação, um } \\
\text { ano e seis meis. }\end{array}$ & $\begin{array}{|lr|}\text { tireoideopatia. } & \text { Atualmente } \\
\text { está mais rouca porque está } \\
\text { gripada. } \quad \text { D }\end{array}$ \\
\hline $\begin{array}{l}\text { 13E Não, minha voiz é assim sempre. Ah, } \\
\text { sempri assim, ... toda vida foi assim... eu } \\
\text { gostu di se alegre }{ }^{e} \text {, eu gosto di cunversa, dá } \\
\text { risada... i gost" tamém di dança... gostu } \\
\text { muito tamém assim, dança... assim } \\
\text { iscondidu du meu maridu... Iscundidu, qui } \\
\text { daí eli fala qui eu so, qui eu to sortandu a } \\
\text { franga. Ah, mas eu so assim... Num sei } \\
\text { ixplica comu podi aparece... num sei ixplica } \\
\text { mesmu. }\end{array}$ & $\begin{array}{l}\text { (1) Presume que sua voz foi } \\
\text { sempre assim, toda vida. Não } \\
\text { sabe explicar como é a sua } \\
\text { voz. A } \\
\text { (2) Gosta de ser alegre, de } \\
\text { conversar, dar risadas e de } \\
\text { dançar, mesmo que seja } \\
\text { escondida do marido. C }\end{array}$ \\
\hline $\begin{array}{l}14 \mathrm{E} \text {... minha voz é normal assim, comu, } \\
\text { comu eu sempri fui..., desd' criança mi crié } \\
\text { assim... às veiz, to té agora vivenu... é } \\
\text { isso qui eu num sei, num sei explica. U que } \\
\text { qui é? Num sei, num tenhu a minima idéia } \\
\text { como é qui... }\end{array}$ & $\begin{array}{l}\text { Considera sua voz normal e } \\
\text { que sempre foi assim, desde } \\
\text { criança. Não tem a mínima } \\
\text { idéia de como explicar o que é } \\
\text { voz normal. A }\end{array}$ \\
\hline $\begin{array}{l}\text { 15E ... eu não sei. Eu não sei fala como é } \\
\text { minha voz. Eu não gosto da minha voz, sei } \\
\text { lá ... Eu nunca ouvi a minha voz gravada, } \\
\text { mas devi se horrivel, pelo jeitu. Não, não } \\
\text { achu jeitu di pensa, ... (ouve a voz } \\
\text { gravada) Num dá pra entende grandi coisa, } \\
\text { não, mas é uma voz agradável de ouvi, } \\
\text { melhor du quieu pensava... }\end{array}$ & $\begin{array}{l}\text { Julga não saber explicar } \\
\text { como é sua voz. Mas não } \\
\text { gosta dela. Acha que deve ser } \\
\text { horrível. Depois de se ouvir } \\
\text { relata que apesar de não dar } \\
\text { para entender muita coisa do } \\
\text { que é falado, é agradável, } \\
\text { melhor do que pensava. B }\end{array}$ \\
\hline $\begin{array}{l}16 E \text {... conformi a hora eu tamém do uns } \\
\text { berrinhu... conformi a hora eu so... mais } \\
\text { suavi. Eu achu qui ela é meiu, meiu lá i } \\
\text { meiu cá, num sei ti dize ao certu. Pois é, às } \\
\text { vezis conformi u estadu a genti...tem uma } \\
\text { certa.. postura, conformi é uumaa.. } \\
\text { conformi otro estadu você eli eleva mais a } \\
\text { voz. ... pode aparece agressividade na sua } \\
\text { voz ou mais suavidade, podi sim... Tudu } \\
\text { issu vem, achu qui cum todus, qui às vezis } \\
\text { quanu você está alterada, você muda seu } \\
\text { tom de voz, nem qui você não queira, você } \\
\text { muda, a genti muda... i quandu é uma } \\
\text { coisa assim mais... problemáticu você tem } \\
\text { qui usa.... mais a sensibilidade... Mais } \\
\text { suavidade.... você sabi qui até cus poblema } \\
\text { da genti a genti aprendi... a doença, a } \\
\text { dor... a perda, as dificuldadi ensinam a } \\
\text { genti, tudu a genti tira um proveitu na } \\
\text { vida... ii cu essi poblema da minha neta... a } \\
\text { genti ta sendu assimm... menos amarga... } \\
\text { A genti ta venu qui as coisas não é só na } \\
\text { agressividadi, irritabilidadi, u amor qui a }\end{array}$ & $\begin{array}{l}\text { (1) Presume que, conforme } \\
\text { seu estado, a voz pode ser } \\
\text { mais elevada (aguda) ou mais } \\
\text { suave. } \\
\text { (2) Todos mudam o tom de } \\
\text { voz podendo aparecer } \\
\text { agressividade ou suavidade. } \\
\text { Mesmo que não se queira ela } \\
\text { muda muito no dia-a-dia, e } \\
\text { quando a situação é mais } \\
\text { problemática tem que se usar } \\
\text { a sensibilidade, a suavidade. } \\
\text { C } \\
\text { (3) Acha também que as } \\
\text { pessoas aprendem com os } \\
\text { problemas e dificuldades, que } \\
\text { de tudo é possível tirar } \\
\text { proveito na vida. Com a } \\
\text { doença da neta (depressão } \\
\text { profunda) está aprendendo a }\end{array}$ \\
\hline
\end{tabular}


genti ta pondo, uma pessoa falo pra genti... às vezis nem u medicamentu qui a genti ta dandu pra ela, não leva a nada, é u amor, u carinhu, a atenção qui a genti dedica... i é uma verdadi, qui é a melhor terapia. E essi amor, essi carinhu podi transparece na voz, com certeza. A voz é que nem u dia a dia da genti... muda muitu. Tudu na genti muda... Ce ta feliz, ta sorrindu, a voz podi te leva, ta cantandu... eu so muitu cantadera... sempri gostu di canta, agora não tantu, por causa aí do pobrema em casa que ta passanu, mais eu acordu as minhas filhas cum muitu cantu, cantu bastanti, cantei quanu era menina nas radio... então, minha mãe era muitu cantadora tamém, então, agora não porque a genti já ta assim, numa situação meiu assim, qui procura evita barulhu.... você liga o rádio baxu... iscuta uma música baxa, sussegada, mais... qué cunversa, a genti cunversa mais baxu... Então, ce vê comu muda as coisa...

17E Ah, eu gostu da minha voiz... Eu gostu. Eu achu qui é uma voz bunita... Num é uma voiz roca...

18E Minha voz é feia... Eu achu... pra começa eu tenhu a língua meiu travada ... Eu achu feia... Ah, num sei explica... é uma voz qui sai lá de dentru... Num sei não se é fina, eu num possu explica purque..., num sei... Voz qui sai lá di dentru, bom num sei, eu achu minha voz uma voz pertada... Num é aquela voz qui sai gritanu... aquela voz qui é uma voz fina... a minha não, eu achu a minha voz meiu grossa... Tem genti qui fica parecenu qui tem a voz fina... a minha não.... já é meiu grossa, eu não gostu purque é grossa, achu melhor a voz fina.

19E E só sei quieu queria se calma, quiria se bem, quiria se assim, quiria se qui nem as otras pessoa, amorosa, eu num so calma, eu so diferenti di todus, di todu mundu achu, di todu mundu quieu conheçu... pur causa da minha cabeça... Ah, minha voiz eu quiria canta, mais eu num possu canta, eu num possu canta purqueu num tenhu (tenta fazer um som ser menos amarga, agressiva, irritada, e ver que o amor, o carinho e atenção dedicada, às vezes fazem mais efeito que a medicação; é a melhor terapia. Ela gosta muito de cantar e sempre acordou as filhas cantando. Hoje, por estarem com a neta doente em casa, tentam fazer menos ruído, conversam em volume mais baixo, ouvem músicas mais tranqüilas no rádio.

(3) Esses sentimentos e sensações podem transparecer na voz.

D
Gosta da sua voz. Acha que é bonita por não ser rouca. A

Considera sua voz feia e que tem a língua travada.

Mas aponta ser uma voz que sai de dentro, apertada, um pouco grossa. Não é uma voz fina (aguda) nem que sai gritada, como de algumas pessoas. Não gosta por ser grossa e acha melhor a voz fina.

(1) Relata que queria ser calma, igual às outras pessoas, amorosa. Considerase diferente de todos que conhece por causa da sua cabeça (tem diagnóstico de uma psicopatia). Sente-se prejudicada por não manter atenção ou memória, pois 


\begin{tabular}{|c|c|}
\hline $\begin{array}{l}\text { agudo e não sai som, só soprosidade) ó, } \\
\text { sem u dó eu não cantu nada, tenhu coisa, } \\
\text { minha voiz é muitu ruim, ruim dimais pa } \\
\text { canta. Pa fala eu falu altu dimais, meus } \\
\text { filhus falam pra mim quieu falu altu dimais, } \\
\text { quieu divia fala mais baxu, mais... eu so } \\
\text { assim... eu falu sim altu nu ônibus, } \\
\text { conversu cum todu mundu... a outra coisa, } \\
\text { terça-fera eu saí, fui compra um tênis, } \\
\text { perdi u tênis... setenta real perdi no ônibus, } \\
\text { num sei aondi, num sei si dexei mi } \\
\text { robarem, num sei o qui aconteceu, cheguei } \\
\text { im casa sei quieu cheguei im casa sem u } \\
\text { tênis. Sábadu atrasadu eu fui fugi du veiu } \\
\text { pa dança, daí qui gozadu, daí nu ônibus fui } \\
\text { robada... robaro meu dinheru i robaru até } \\
\text { meu cartão, até minha entrada du baile... } \\
\text { Agora eu, saiu dá vontadi di i nu banheru, } \\
\text { caiu um tombu, machucu u juelhu, olha aí } \\
\text { ó u tombu quieu caí (mostrando os joelhos } \\
\text { machucados) Ah, ta locu, a sorti minha é } \\
\text { quieu num cai em cima du monti di garrafa } \\
\text { quebrada qui tinha lá.... }\end{array}$ & $\begin{array}{l}\text { perde dinheiro, compras, e } \\
\text { até cartão para o baile, ou é } \\
\text { roubada sem perceber nos } \\
\text { ônibus; ultimamente quando } \\
\text { sai de casa fica com diarréia a } \\
\text { ponto de ter que descer } \\
\text { rapidamente da condução } \\
\text { para não evacuar em público. } \\
\text { Da última vez, caiu perto de } \\
\text { cacos de garrafas e machucou } \\
\text { os joelhos. E } \\
\text { (2) Gostaria de cantar, mas } \\
\text { não consegue porque a voz } \\
\text { não alcança agudos, então } \\
\text { acha que ela é ruim demais. } \\
\text { Seus filhos dizem que fala } \\
\text { muito forte, porém acha que } \\
\text { esse é seu jeito e que gosta } \\
\text { de conversar com todo } \\
\text { mundo. B }\end{array}$ \\
\hline $\begin{array}{l}\text { 20E Comu quieu possu ti dize? Num mudo } \\
\text { a minha voz, é sempre a mesma... Minha } \\
\text { voz .... Eu pensu qui a minha voz é normal } \\
\text { assim... Eu falu mais baixu, quanu eu queru } \\
\text { eu falu altu... não possu dize mais nada }\end{array}$ & $\begin{array}{l}\text { Sente dificuldade de explicar } \\
\text { sua voz, mas acha que não } \\
\text { mudou e é normal: quando } \\
\text { quer fala fraco ou forte A }\end{array}$ \\
\hline $\begin{array}{l}21 E \text { Ah, eu achi qui não purque pra mim eu } \\
\text { achi qui num mudo nada. Eu achu qui so a } \\
\text { mesma pessoa, qui gostu di conta piada, } \\
\text { estória, ri, i agora as amiga nunca mi falaro } \\
\text { qui a minha voz tava deferente... Eu achu } \\
\text { qui a minha voiz é um poco... fina e muito } \\
\text { vagarosa ... pra conversa, pra...responde u } \\
\text { telefoni }\end{array}$ & $\begin{array}{l}\text { (1) Acha que não mudou nem } \\
\text { a voz nem como pessoa e que } \\
\text { gosta de contar piadas, } \\
\text { estórias, de rir e que as } \\
\text { amigas nunca falaram que } \\
\text { estava diferente. C } \\
\text { (2) Concebe sua voz um } \\
\text { pouco fina e vagarosa para } \\
\text { conversar e responder ao } \\
\text { telefone. }\end{array}$ \\
\hline $\begin{array}{l}22 E \text { Eu não sei, não sei dize come qui ta } \\
\text { minha voz... Eu achu a minha voz normal... } \\
\text { Ela não é, às vezis reclamam qui é alta, } \\
\text { mas eu num achu... Ás veiz a minha filha } \\
\text { chega i diz "mãe, fala mai baxu", mais eu } \\
\text { num num achu quieu to falanu altu.... } \\
\text { Intão, ieu num sei... }\end{array}$ & $\begin{array}{l}\text { Avalia que não sabe dizer } \\
\text { como é sua voz, r mas } \\
\text { considera normal. A filha, às } \\
\text { vezes, reclama que é forte, } \\
\text { porém ela não concorda. } \\
\text { A }\end{array}$ \\
\hline $\begin{array}{l}23 \text { Ea minha voz? I agora? Qui quieu vo } \\
\text { dize da minha voz? Eeeuu... eu achu a } \\
\text { minha voiz bunita... beim... I quanu eu to } \\
\text { tristi tamem... Fico...às veiz to cum } \\
\text { problema, aqueli problema quieu ti falei, du }\end{array}$ & $\begin{array}{l}\text { (1) Julga sua voz bonita e } \\
\text { bem. A } \\
\text { (2) Quando está triste por } \\
\text { depressão sente a que a voz } \\
\text { fica fraca, apertada, sem }\end{array}$ \\
\hline
\end{tabular}




\begin{tabular}{|c|c|}
\hline $\begin{array}{l}\text { meu isposu qui faleceu, daí então eu ... } \\
\text { mordo a voiz tamém... i quandu to alegri } \\
\text { "bom-dia" (forte, claro, sorrindo) falu pras } \\
\text { menina... mais quanu to meia tristi "oi, } \\
\text { tudu beim" (fraco, sem projeção e mal } \\
\text { articulado).... "oh, mãe u qui a senhora ta } \\
\text { tristi?" Achu qui elas deduzem tamém pela } \\
\text { minha voiz... Qui eu to tristi, elas adivinham } \\
\text { quanu eu to tristi só pela voz.. Eu achu, é } \\
\text { minha opinião... }\end{array}$ & $\begin{array}{|lr|}\text { projeção, mal articulada. Os } \\
\text { filhos deduzem pela sua voz e } \\
\text { questionam a razão. } \\
\text { Quando está } & \text { alegre, } \\
\text { demonstra sorrindo. } & \text { C }\end{array}$ \\
\hline $\begin{array}{l}\text { 24E Da minha voz? Ah, não sei ... Não } \\
\text { possu responde...Eu gostu da minha voz.... } \\
\text { mas não... não sei responde. }\end{array}$ & $\begin{array}{l}\text { Acha que não sabe falar a } \\
\text { respeito da sua voz, mas } \\
\text { gosta dela. A }\end{array}$ \\
\hline $\begin{array}{l}\text { 25E Ah, eu achu quieu to meia deprimida... } \\
\text { Eu mi sintu assim, quieu to meia deprimida, } \\
\text { quieu to meia assim com problema côa } \\
\text { minha mãe qui ta doenti... intão, eu to sim } \\
\text { meia deprimida, por exemplu, essa semana } \\
\text { eu to me achanu deprimida, eu sintu assim } \\
\text { quieu to, essa semana não, faiz quinzi dia... } \\
\text { eu to côa minha mãe duenti, quiela quebro } \\
\text { u fêmur, eu to ajudanu cuida dela, intão, } \\
\text { pur mais quieu queru mostra aligria, eu } \\
\text { num to alegri.. intão eu sintu sim, inté sintu } \\
\text { aquela vontadiii ... quela coisa qui ta mi } \\
\text { apertanu, num que solta a voiz tudu... } \\
\text { Sintu assim, hoji, por exemplu, quieu vo } \\
\text { fala cum você eu sintu assim qui eu tooo.... } \\
\text { forçanu pra mim conversa... Eu to sintinu } \\
\text { assim, meiu, essa liberdadi di fala cum } \\
\text { você... mais..., hoji, por exemplu eu to côa } \\
\text { voiz di quem ta assiiim, deprimida mesmu } \\
\text { sabi... O tamem a genti podi ta finginu, } \\
\text { pru médicu... }\end{array}$ & $\begin{array}{l}\text { (1) Reputa que, por estar } \\
\text { deprimida, cuidando da mãe } \\
\text { que sofreu um acidente e } \\
\text { quebrou o fêmur, mesmo } \\
\text { querendo mostrar alegria e } \\
\text { sentindo liberdade para falar } \\
\text { com a entrevistadora, } \\
\text { C } \\
\text { (2) Percebe que a sua voz } \\
\text { está apertada, que não solta, } \\
\text { forçando para conversar, } \\
\text { traduzindo a depressão. } \\
\text { (1) E que isso poderia ser } \\
\text { usado para fingir para o } \\
\text { médico. C }\end{array}$ \\
\hline $\begin{array}{l}\text { 26E Minha voz é beem... qui é ruim... achu } \\
\text { qui é, minha voiz é bem ruim, é assiiim } \\
\text { roca... Tem tempu quela me tranca assim } \\
\text { quanu eu começu a canta, eu achu quiela } \\
\text {... não ta beim. }\end{array}$ & $\begin{array}{l}\text { Pensa que sua voz é ruim, } \\
\text { rouca, que tranca quando } \\
\text { começa a cantar e que não } \\
\text { está bem. }\end{array}$ \\
\hline $\begin{array}{l}\text { 27E Da minha voz? Eu achu a minha voz } \\
\text { um pocooo.. presa... Eu não tenhu } \\
\text { assimmm, eu tenhu um poco di dificuldad'. } \\
\text { Ela mostra quieu so assim pra dentru, eu } \\
\text { so, bastant assim fechada.... É dificil assim } \\
\text { u dia quieu tooo, contente assim, bem feliz } \\
\text { é a hora quieu to cos meu netos, cos meu } \\
\text { filho... aí eu me sintu feliz...Quanu eu to } \\
\text { nervosa eu tenhu assimm muita }\end{array}$ & $\begin{array}{l}\text { (1) Considera sua voz um } \\
\text { pouco presa, que tem } \\
\text { dificuldaderar } \\
\text { (2) Sua voz mostra que ela é } \\
\text { uma pessoa para dentro, } \\
\text { fechada. Sente-ser feliz } \\
\text { somente quando está com os } \\
\text { filhos, com os netos. Quando } \\
\text { está nervosa, conforme a }\end{array}$ \\
\hline
\end{tabular}




\begin{tabular}{|c|c|}
\hline $\begin{array}{l}\text { dificuldade, conforme as pessoa... Eu ficu } \\
\text { assim (cochichando) "ai qui medu de fala, } \\
\text { de fala uma bobage..." Me senti segura } \\
\text { aqui, bastant. }\end{array}$ & $\begin{array}{l}\text { pessoa com quem conversa, } \\
\text { sente medo de falar alguma } \\
\text { bobagem. }\end{array}$ \\
\hline $\begin{array}{l}\text { 28E A minha voz? Eu so assim... Não sei } \\
\text { como faze pra fala... Não posso dize comu } \\
\text { ela é... Quandu mi tratam cum gritu eu } \\
\text { também gritu, é mesma coisa. Eu achu qui } \\
\text { é pra mi defende, si não for por dinheiru, } \\
\text { as pessoa gritam eu gritu tamem, agora si } \\
\text { não grita, fala numa boa, i conversa ai sim, } \\
\text { eu cunversu... si fo pra grita, eu gritu } \\
\text { tamém.... Daí às vezis, às veiz põe respeitu, } \\
\text { às veiz fica na mesma... }\end{array}$ & $\begin{array}{l}\text { Observa que não sabe falar } \\
\text { sobre sua voz. Mas quando é } \\
\text { tratada com gritos, grita } \\
\text { também, pois, às vezes, isso } \\
\text { impõe respeito. Deduz que } \\
\text { grita para se defender, porque } \\
\text { se a pessoa conversa sem } \\
\text { gritar, ela também conversa } \\
\text { bem. c }\end{array}$ \\
\hline $\begin{array}{l}\text { 29E A minha voz? Ah, eu num sei... num } \\
\text { sei sieu agradu alguém, eu gostu, gostu da } \\
\text { minha voz. É possível agrada côa voz, } \\
\text { assim, qui nem eu falei pra você,... às vezis } \\
\text { a pessoa, tem muitas pessoas qui são } \\
\text { agressivu... i pode aparece sim... Apareci } \\
\text { conformi ce conversa cuma pessoa já sabi } \\
\text { comu qui a pessoa é, ... Por mais qui num } \\
\text { entenda muitu, mais ce sabi... Sabi si devi } \\
\text { convive com aquela pessoa .. sempri o } \\
\text { não.... Eu so assim, se a pessoa chega nua, } \\
\text { nua, num lugar, i daí a pessoa mi, mi de } \\
\text { uma chapada comu diz u povu, eu já mi } \\
\text { afastu, falo "não, vamu afasta, purque aqui } \\
\text { num é u meu lugar" Eu façu assim, sempri } \\
\text { fiz... }\end{array}$ & $\begin{array}{l}\text { (1) Não sabe se sua voz } \\
\text { agrada alguém, mas ela } \\
\text { gosta. } \\
\text { (2) Supõe ser possível agradar } \\
\text { as pessoas com a voz, pois } \\
\text { algumas rostram } \\
\text { agressividade e por mais que } \\
\text { ela não entenda muito (do } \\
\text { assunto), conforme conversa, } \\
\text { percebe como a pessoa é. Se } \\
\text { for agressiva ela sempre se } \\
\text { afasta. C } \\
\text { C }\end{array}$ \\
\hline $\begin{array}{l}\text { 30E ... Ah, minha voz éé.. sempre, sempri } \\
\text { a mesma assim, eu num mudu de ... u meu } \\
\text { sotaqui, você diz? Quandu eu num to beim, } \\
\text { daí eu mudo de voz, assim, eu ficu meia } \\
\text { assim, eu ficu mais assim.. agitada, ficu } \\
\text { meia assim fraca... a vozinha, elis acham } \\
\text { assim quieu to côa vozinha mais diferente, } \\
\text { intão, eu tamem percebu, eu percebu a } \\
\text { minha voz. Pareci qui ela fica tipu assim } \\
\text { cuma cansera, eu ficu assim fraca, daí a } \\
\text { voz sai fraquinha tamém, sai débil... }\end{array}$ & $\begin{array}{l}\text { (1) Opina que a sua voz é } \\
\text { sempre a mesma e que ela } \\
\text { também não muda, quando } \\
\text { está bem. } \\
\text { (2) Se ficar agitada, fraca, os } \\
\text { outros percebem e ela } \\
\text { também, que a voz é } \\
\text { diferente, fraquinha, débil e } \\
\text { cansada. c }\end{array}$ \\
\hline
\end{tabular}

\section{INSTRUMENTO DE ANÁLISE DO DISCURSO 2}

Questão 3: E a sua voz? Fale um pouco sobre ela. A = Características positivas observadas na própria voz 


\begin{abstract}
EXPRESSÕES -CHAVE
(1) Bom, eu tenho uma voz... eu achu que ela é um tom..., suave... eu fazia parte do soprano... Então uma voz bastante aguda, assim a gente eleva bastante... Segurando o, contralto i $0 . .$. tenor... ...pelo meu trabalho qui é agitado, eu já chegava lá super cansada... i... depois eu fui deixanu...

(4) ..., eu acho que minha voz é... normal assim... se eu to num...ta se sentindu bem, fala as coisa bonita, acho isso aí... (5) Eu tava te falanu queu tenho a voz tão forte, que quando puxava o canto na igreja, na minha comunidade, ele.. eu puxei tão alto, tanto que o padre que tava celebrando, pego e boto a mão nos óculos i falo i riu Diz: mas ela quande abre a boca pra canta.. sai, cuida do meus óculos. E a minha amiga que tava durmindu... diz que se acordo com a minha voz. Num dava muito di ajuda, mas tu me acordo na hora de canta ... Realmente eu tenho a voz bem forte...

(9) Eu adoro a minha voz... Mas num sei o que que de repenti as pessoa acha... De repent a pessoa.. ah, vai conversa cua genti ii, num acha assim quii... ....Mas eu ainda achu qui as pessoa gosta, é. Achu qui é um tant " suave..., é assim quieu achu.

(10) É dificil dize... Como é a minha voz? ...

DISCURSO DO SUJEITO COLETIVO

Eu tenho um tom suave na voz. Fazia parte das sopranos, sustentando com o tom elevado, agudo, o contralto e o tenor. Porém, como meu trabalho é agitado, ficava cansada e deixei de ensaiar. A minha voz é tão forte que quando cantei na Igreja da comunidade o padre segurou os óculos (para não quebrarem as lentes) e minha amiga que estava dormindo acordou. Eu gosto de conversar com todo mundo, porque se estou me sentindo bem, falo coisas bonitas. Desse modo, eu adoro a minha voz, porém, não sei o que as pessoas pensam a respeito dela, ou se agrada alguém, mas eu acho que gostam, porque é suave. Contudo, às vezes, reclamam que a voz é forte. Assim, eu gosto, acho bonita, bem, porque não é rouca, e creio que ela seja boa porque eu consigo falar direito. Ela sempre foi assim normal, desde criança me criei assim e até hoje estou vivendo. Enfim, é um pouco difícil definir a minha voz, porque dependendo da maneira como eu falo, ela pode se tornar irritante até para mim, como quando se grita. Existem várias maneiras de se falar e tenho aprendido que se for de forma branda, com amor, as pessoas e eu ganhamos muito mais.
\end{abstract} eu poderiaaa fala alguma coisa, i de repenti ela si torna irritanti, a minha voz, pra mim mesmo, dependen ${ }^{\mathrm{d} u}$ a manera com qui eu falu, a, a forma quieu falu... Muitas vezes eu posso grita, ai eu to mi tornanu irritanti pra mim mesmu, agora... tem várias maneras di si fala, i eu tenhu aprendidu quiii seu fala brandu, seu fala com amor... quas pessoas, eu ganhu muitu mais...

(11) ... eu creiu qui é bão... Purque eu cunsigu fala direitu...

(13) Não, minha voiz é assim sempre. Ah, sempri assim, ... toda vida foi assim... Num sei ixplica comu podi aparece... num sei ixplica mesmu.

(14) ... minha voz é normal assim, comu, comu eu sempri fui..., desd criança mi criei assim... às veiz, to té agora vivenu...

(17) Ah, eu gostu da minha voiz... Eu gostu. Eu achu qui é uma voz bunita... Num é uma voiz roca...

(20) Num mudo a minha voz, é sempre a 
mesma... Minha voz .... Eu pensu qui a minha voz é normal assim... Eu falu mais baixu, quanu eu queru eu falu altu...

(22) Eu achu a minha voz normal... Ela não é, às vezis reclamam qui é alta, mas eu num achu... As veiz a minha filha chega i diz "mãe, fala mai baxu", mais eu num num achu quieu to falanu altu.... Intão, ieu num sei...

(23) Da minha voz? I agora? Qui quieu vo dize da minha voz? Eeeuu... eu achu a minha voiz bunita... beim...

(24) Da minha voz? Ah, não sei ... Não possu responde...Eu gostu da minha voz.... mas não... não sei responde.

(29) A minha voz? Ah, eu num sei... num sei sieu agradu alguém, eu gostu, gostu da minha voz.

\section{B = Características negativas observadas na própria voz}

\begin{tabular}{|c|c|}
\hline EXPRESSÕES -CHAVE & DISCURSO DO SUJETTO COLEIIVO \\
\hline $\begin{array}{l}\text { (2) Ah, eu acho que já... a voz da gente já } \\
\text { muda de assim... fica mais grossa, já num fica } \\
\text { aquela voz mais suave... Purque... a gente } \\
\text { nota pela fala já, fica mais roca, achu que em } \\
\text { todos os aspecto... Tanto pra fala, como pra } \\
\text { canta... É, eu num tinha a voz assim roca } \\
\text { como eu tenhu agora.. Eu não tinha a voz } \\
\text { assim, minha voz era um poco mais... num } \\
\text { veju tantu assim no no fala assim, fica mais } \\
\text { mais presa... Eu num tinha a voz assim, minha } \\
\text { voz era mais.. mais limpa, e hoje já ta mais... } \\
\text { Ah, eu, eu sintu assim comu si.. na garganta } \\
\text { alguma coisa prendesse na hora de fala, eu to } \\
\text { falando com você assim, eu sinto que aqui na } \\
\text { garganta parece que prende na hora de fala, } \\
\text { antigamente não. Soltava a voz mais, não } \\
\text { tinha essa roquidão, essa.. coisa presa pra } \\
\text { conversa, qui a gente falandu prende... E } \\
\text { antigamente eu sentia que soltava mais a } \\
\text { voz... era mais fácil fala... mais limpa... num } \\
\text { ficava aquela coisa presa... e hoje não, hoje } \\
\text { tem mais roca, mais grossa, engrosso mais a } \\
\text { voz. Eu não tinha essa voz grossa... } \\
\text { (3) Minha voz é grossa i feia... eu achu feia, eu } \\
\text { não gosto da minha voz, fala grossa, parece di } \\
\text { homi... Foi, foi engrossando a voz, faz cincu, } \\
\text { seis anus... } \\
\text { (6) ... a minha voz acho qui num mudo nada, } \\
\text { desde quiii, eu mim tendo por vó... Já so vó } \\
\text { guatore vezes. iii eu acho aue a minha voz }\end{array}$ & $\begin{array}{l}\text { Antigamente eu soltava mais a voz, era mais } \\
\text { fácil, mais limpa. Atualmente minha voz } \\
\text { mudou, ficou mais grossa, perdeu a suavidade } \\
\text { tanto para falar, quanto para cantar, ficou } \\
\text { rouca, mais presa, trancada, não é uma coisa } \\
\text { perfeita, mostra um pouco de dificuldade, que } \\
\text { notei de uns anos para cá. Eu queria cantar, } \\
\text { mas não tenho os agudos, ficou ruim demais } \\
\text { para cantar. É uma voz que sai lá de dentro, } \\
\text { não posso explicar, é uma voz apertada, não é } \\
\text { gritada nem fina, é meio grossa, foi } \\
\text { engrossando, é forçada, feia e eu não gosto, } \\
\text { parece voz de homem. Deve ser horrivel ouví- } \\
\text { la, ou pode até ser melhor do que eu penso. } \\
\text { Dizem que eu falo muito intenso, mas hoje } \\
\text { estou com a voz deprimida, forçada, não está } \\
\text { bem. Contudo, também não gosto quando ela } \\
\text { fica muito aguda, ardida, engraçada, } \\
\text { irreconhecível para mim, estalada, um pouco } \\
\text { rápida demais, parecendo uma matraca. }\end{array}$ \\
\hline
\end{tabular}


continua a mesma, igual... A voz minha continua a mesma..., eu to do mesmu jeitu. A minha voz é um poco aguda eu acho. Num sei se acha, mais tem veizes queu é, assim, deu fala... eu falo assim um poco ardido... um jeito assim engraçado, Eu achu, num sei i..., é eu já ouvi minha voz, eu já gravei já ouvi, falei " Nossa Senhora D'Aparecida num é ieu qui to falanu aqui, é outra pessoa", purque tá muito fea essa voz, i hoj eu to qua voz meia estranha purque eu to qua garganta um poco dueno... mais.. quando eu gravo eu morro dá risada, de vê minha voz no gravador... purque eu acho tão engraçada, é uma voz assim muita aguda..., estalada... Então, i eu so meio poco rápida pra fala... Então, nossa, pareci uma matraca falano...

(7) Minha voz num ta aquela coisa perfeita... Pior é qui eu num sei a palavra pra dize como qui é a minha voz...., Eu acho minha voz é um poco roca de uns anos pra cá, num é mais uma voz limpa qui nem era antigamente... É um poco mais roca. Antes ela era uma voz mais limpa, antes uns trinta anos pra cá eu acho, trinta anos atrás agora, dos vinte anos pra cá quela mudo um poco... Eu tinha voz mais limpa uns quatro anos pra trás, agora de um tempo pra cá eu já noto qui é um poco roca...

(12) Ah, eu mesma nem noto... Eu noto assim: agora depois da tiróidi eu fiquei roca, fiquei muito deferente purque nois somo evagelho, qui nois gosta di canta, intão minha voiz roco, eu fui...eu cantava muito bem assim... depois eu achei estranha a minha voiz, eu achei muito deferente, fiquei roca.

(15) ... eu não seí. Eu não sei fala como é minha voz. Eu não gosto da minha voz, sei lá ... Eu nunca ouvi a minha voz gravada, mas devi se horrivel, pelo jeitu. Não, não achu jeitu di pensa, ... (ouve a voz gravada) Num dá pra entende grandi coisa, não, mas é uma voz agradável de ouvi, melhor du quieu pensava... (18) Minha voz é feia... Eu achu... pra começa eu tenhu a língua meiu travada ... Eu achu feia... é uma voz qui sai lá de dentru... Num sei não se é fina, eu num possu explica purque..., num sei... Voz qui sai lá di dentru, bom num sei, eu achu minha voz uma voz pertada... Num é aquela voz qui sai gritanu... aquela voz qui é uma voz fina... a minha não, eu achu a minha voz meiu grossa... Tem genti 
qui fica parecenu qui tem a voz fina... a minha não... já é meiu grossa, eu não gostu purque é grossa, achu melhor a voz fina.

(19) Ah, minha voiz eu quiria canta, mais eu num possu canta, eu num possu canta purqueu num tenhu (tenta fazer um som agudo e não sai som, só soprosidade) ó, sem u dó eu não cantu nada, tenhu coisa, minha voiz é muitu ruim, ruim dimais pa canta. Pa fala eu falu altu dimais, meus filhus falam pra mim quieu falu altu dimais, quieu divia fala mais baxu, mais... eu so assim... eu falu sim altu nu ônibus, conversu cum todu mundu...

(25) intão eu sintu sim, inté sintu aquela vontadiii ... quela coisa qui ta mi apertanu, num que solta a voiz tudu... Sintu assim, hoji, por exemplu, quieu vo fala cum você eu sintu assim qui eu tooo.... forçanu pra mim conversa... Eu to sintinu assim, meiu, essa liberdadi di fala cum você... mais.... hoji, por exemplu eu to côa voiz di quem ta assiiim, deprimida mesmu sabi...

(26) Minha voz é beem... qui é ruim... achu qui é, minha voiz é bem ruim, é assiiim roca... Tem tempu quela me tranca assim quanu eu começu a canta, eu achu quiela ... não ta beim.

(27) Da minha voz? Eu achu a minha voz um pocooo.. presa... Eu não tenhu assimmm, eu tenhu um poco di dificuldad'...

\section{C = Condição e estado para observação da voz}

\begin{tabular}{|c|c|}
\hline EXPRESSÕES - CHAVE & DISCURSO DO SUJEITO COLEIIVO \\
\hline $\begin{array}{l}\text { (16) Pois é, às vezis conformi u estadu a } \\
\text { genti...tem uma certa.. postura, conformi é } \\
\text { uumaa.. conformi otro estadu você eli eleva } \\
\text { mais a voz. ... pode aparece agressividade na } \\
\text { sua voz ou mais suavidade, podi sim... Tudu } \\
\text { issu vem, achu qui cum todus, qui às vezis } \\
\text { quanu você está alterada, você muda seu tom } \\
\text { de voz, nem qui você não queira, você muda, } \\
\text { a genti muda... } \\
\text { (21) Eu achu qui a minha voiz é um poco... } \\
\text { fina e muito vagarosa ... pra conversa, } \\
\text { pra...responde u telefoni... } \\
\text { (30) Quandu eu num to beim, dai eu mudo de } \\
\text { voz, assim, eu ficu meia assim, eu ficu mais } \\
\text { assim.. agitada, ficu meia assim fraca... a } \\
\text { vozinha, elis acham assim quieu to côa vozinha } \\
\text { mais diferente, intão, eu tamem percebu, eu } \\
\text { percebu a minha voz. Pareci qui ela fica tipu }\end{array}$ & $\begin{array}{l}\text { Conforme o estado a gente tem uma certa } \\
\text { postura, elevando a voz. Assim, pode aparecer } \\
\text { suavidade ou agressividade e se eu estiver } \\
\text { agitada fico com a voz fraca e todos em casa } \\
\text { percebem. Além disso, a minha voz é um } \\
\text { pouco fina e vagarosa para conversar no } \\
\text { telefone. }\end{array}$ \\
\hline
\end{tabular}


assim cuma cansera, eu ficu assim fraca, daí a voz sai fraquinha tamém, sai débil...

\section{D = Funções exercidas pela voz}

\begin{tabular}{|l|}
\hline EXPRESSÕES -CHAVE \\
\hline (1) ... Pedi licença, mais eu pretendo voltá, \\
porque eu gostu muito de fazê alguma coisa \\
prá....porque através dus hinu, da mensagem \\
que a gente passa pas pessoas, então tem \\
pessoas que ta com poblemas e ouvindo..., \\
As vezes faz muito bem pras pessoas ... \\
Muitas vezis, quantas vezes já... a gente se \\
apresento... fim de ano assim no Natal, \\
cantata de Natal..., Então, as pessoas \\
paravam e dizia "oh é muito bonito o que \\
vocês tão fazendo", aquela coisa toda... \\
Então... passo até no jornal, o coral das \\
senhoras... té eles falaram terceira idade, qui \\
bom qui eu já faço parte da terceira idade! \\
Não, mais estava juntu... Então, é uma coisa \\
assim, é muito gratificante, sabe du dia a dia, \\
aquela coisa toda..., i issu no geral, ...é uma \\
coisa qui ajuda você, é ... aumenta tua fé... \\
pelo modo que você...ta ali fazendo aquele \\
trabalhu, ensaiandu, dedicandu, porque... é a \\
obra que tem que faze..., e é um modu de \\
prega... o evangelho pras pessoas...
\end{tabular}

(8) A minha voz, se eu tive bem nervosa, qui nem eu sintu quandu eu veju queu to nervosa pur causa de pobrema, eu sinto qui minha voz modifica um poco. ... o cunversu alto dimais, o cunversu baxo dimais.

(10) ... eu creiu quiii, com a minha voz, qua minha fala, eu possuuu demonstra amor pelas pessoas, qua minha voz eu possuuu, aconselhar ou intão falar às pessoa aquilo qui.. elas necessitam ouvir de repenti, quelas tão passanu por algum problema, então com a minha voz eu posso faze muita coisa... Eu posso até tira uma vida de repenti lá qui ta nu fundu... nu buracu, com a minha voz eu possu chamá-la, possu traze ela di volta à vida...

(13) ... eu gostu di se alegre ${ }^{e}$, eu gosto di cunversa, dá risada... i gost" tamém di dança... gostu muito tamém assim, dança... assim iscondidu du meu maridu... Iscundidu, qui daí eli fala qui eu so, qui eu to sortandu a franga. Ah, mas eu so assim...

(16) ... pode aparece agressividade na sua

\section{DISCURSO DO SUJEITO COLETIVO}

Eu pretendo voltar a ensaiar e cantar no coral porque é gratificante passar a mensagem do evangelho. Isso aumenta a sua fé. Às vezes faz muito bem e as pessoas param para elogiar e incentivar. Embora tenha saído no telejornal como coral da terceira idade. Então eu creio que com a minha voz, a minha fala eu posso demonstrar amor pelas pessoas, aconselhar ou falar o que elas necessitam ouvir por estarem passando por algum problema. Posso até tirar uma pessoa do fundo de um buraco, e trazê-la de volta à vida. É possível agradar as pessoas ou fingir para alguém com a voz. A minha voz é sempre assim, toda vida; eu gosto de ser alegre, conversar, dar risada e de dançar, mesmo que seja escondida do marido. Minha voz não mudou porque eu gosto de contar piadas, estórias, de rir, e nenhuma amiga minha falou que a voz estava diferente. Conforme o seu estado, pode aparecer agressividade ou suavidade na sua voz. Isso acontece com todos, quando se altera, muda o tom de voz, mesmo que não queira. Às vezes, as pessoas são agressivas e conforme você conversa com elas, já nota isso e decide se deve conviver ou não. Eu me afasto, sempre fiz assim. E quando as coisas estão problemáticas precisa de mais sensibilidade, mais suavidade, aprendendo a ser menos amargo, irritados e agressivos. 0 amor, o carinho, a atenção que dedicamos a alguém pode ser a melhor terapia. E esses sentimentos transparecem na voz: se você está feliz, a voz está cantando, agora, na situação inversa evitamos fazer barulho, conversamos em baixa intensidade, ouvimos música sossegada, com pouco volume. A minha voz mostra se sou para dentro, bastante fechada, e se estou nervosa, conforme a pessoa com quem converso, fico com medo de estar falando bobagens, a voz modifica um pouco. Se eu estiver bem nervosa a minha voz modifica e eu falo forte ou fraco demais. Aqui eu me senti segura, 
voz ou mais suavidade, podi sim... i quandu é uma coisa assim mais... problemáticu você tem qui usa.... mais a sensibilidade... Mais suavidade... ... Ce ta feliz, ta sorrindu, a voz podi te leva, ta cantandu... eu so muitu cantadera... sempri gostu di canta, agora não tantu, por causa ai do pobrema em casa que ta passanu, mais eu acordu as minhas filhas cum muitu cantu, cantu bastanti, cantei quanu era menina nas radio... então, minha mãe era muitu cantadora tamém, então, agora não porque a genti já ta assim, numa situação meiu assim, qui procura evita barulhu.... você liga o rádio baxu... iscuta uma música baxa, sussegada, mais... qué cunversa, a genti cunversa mais baxu... Então, ce vê comu muda as coisa...

(21) Ah, eu achi qui não purque pra mim eu achi qui num mudo nada. Eu achu qui so a mesma pessoa, qui gostu di conta piada, estória, ri, i agora as amiga nunca mi falaro qui a minha voz tava deferente...

(23) I quanu eu to tristi tamem... Fico...às veiz to cum problema, aqueli problema quieu ti falei, du meu isposu qui faleceu, daí então eu .. mordo a voiz tamém... i quandu to alegri "bom-dia" (forte, claro, sorrindo) falu pras menina... mais quanu to meia tristi "oi, tudu beim" (fraco, sem projeção e mal articulado)..., "oh, mãe u qui a senhora ta tristi?" Achu qui elas deduzem tamém pela minha voiz... Qui eu to tristi, elas adivinham quanu eu to tristi só pela voz.. Eu achu, é minha opinião...

(25) Ah, eu achu quieu to meia deprimida... Eu mi sintu assim, quieu to meia deprimida, quieu to meia assim com problema côa minha mãe qui ta doenti... intão, eu to sim meia deprimida, por exemplu, essa semana eu to me achanu deprimida, eu sintu assim quieu to, essa semana não, faiz quinzi dia... eu to côa minha mãe duenti, quiela quebro u fêmur, eu to ajudanu cuida dela, intão, pur mais quieu queru mostra aligria, eu num to alegri.. O tamem a genti podi ta finginu, pru médicu...

(27) Ela mostra quieu so assim pra dentru, eu so, bastant assim fechada.... É difícil assim u dia quieu tooo, contente assim, bem feliz é a hora quieu to cos meu netos, $\cos$ meu filho... ai eu me sintu feliz...Quanu eu to nervosa eu tenhu assimm muita dificuldade, conversei bem, porém se me tratam com gritos, eu grito também, que é para me defender ou impor respeito, nem sempre conseguido. Quando estou triste, meio deprimida, com problemas, por mais que eu sinta vontade de mostrar alegria, a voz demonstra a depressão, fica apertada, fraca e os mais íntimos adivinham, deduzem minha tristeza só pela voz. Se estou alegre, estou bem, aí a voz muda e fica mais agitada. 
conforme as pessoa... Eu ficu assim (cochichando) "ail qui medu de fala, de fala uma bobage..." Me senti segura aqui, bastant.

(28) A minha voz? Eu so assim... Não sei como faze pra fala... Não posso dize comu ela é... Quandu mi tratam cum gritu eu também gritu, é mesma coisa. Eu achu qui é pra mi defende, si não for por dinheiru, as pessoa gritam eu gritu tamem, agora si não grita, fala numa boa, i conversa ai sim, eu cunversu... si fo pra grita, eu gritu tamém... Daí às vezis, às veiz põe respeitu, às veiz fica na mesma...

(29) É possivel agrada côa voz, assim... às vezis a pessoa, tem muitas pessoas qui são agressivu... i pode aparece sim... Apareci conformi ce conversa cuma pessoa já sabi comu qui a pessoa é, ... Por mais qui num entenda muitu, mais ce sabi... Sabi si devi convive com aquela pessoa .. sempri o não.... Eu so assim, se a pessoa chega nua, nua, num lugar, i daí a pessoa mi, mi de uma chapada comu diz u povu, eu já mi afastu, falo "não, vamu afasta, purque aqui num é u meu lugar" Eu façu assim, sempri fiz...

(30) Quandu eu num to beim, daí eu mudo de $\mathrm{voz}_{f}$ assim, eu ficu meia assim, eu ficu mais assim.. agitada, ficu meia assim fraca... a vozinha, elis acham assim quieu to côa vozinha mais diferente, intão, eu tamem percebu, eu percebu a minha voz. Pareci qui ela fica tipu assim cuma cansera, eu ficu assim fraca, daí a voz sai fraquinha tamém, sai débil...

\section{$\mathbf{E}=$ Fatores referidos de interferência na qualidade vocal}

\section{EXPRESSÕES -CHAVE}

(2) E antigamente eu sentia que soltava mais a voz... era mais fácil, a fala... mais limpa... num ficava aquela coisa presa... e hoje não, hoje tem mais roca, mais grossa, engrosso

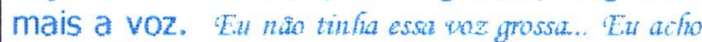
que é devido a menopausi... í, maioria das pessoas falam... que muda $u$, u comportamentu, muda a vois, muda.. Mas eu acredito que sim, que seja mais pelu fatu da menopausa....

(5) e ai eu sempre procuru trabalha ela... abri bem a garganta, solta bem a voz, i pur assim, te agora se sainu bem.
DISCURSO DO SUJEITO COLETIVO

Tudo na gente muda, muda muito e dizem que a menopausa modifica a voz, que ela fica mais grossa, como de homem. Os sentimentos e sensações podem afetar a voz, contudo, as tireoideopatias também deixam a voz mais rouca. Algumas pessoas durante uma gripe apresentam a voz tapada e rouca e exercícios para a laringe também influenciam. 
(6) ... muitas pessoa falo qui. quanto entra na menopausa a voz muda também... Fala qui a voz muda mais grossa..., sei lá, fica cum voz di home... cria mais pêlo, eu acho eu num to com nen fum dessis ploblema ainda.. Pode se que tai vim

(7) Eu acho minha voz é um poco roca de uns anos pra cá, num é mais uma voz limpa qui nem era antigamente... É um poco mais roca. Antes ela era uma voz mais limpa, antes uns trinta anos pra cá eu acho, trinta anos atrás agora, dos vinte anos pra cá quela mudo um poco, num sei se é pur causa da menopausa... mas menopausa mesmo quieu to fazeno tratamento, purque eu tomava aquela injeção Denitriu, que agora ela ta proibida.... Eu tinha voz mais limpa uns quatro anos pra trás, agora de um tempo pra cá eu já noto qui é um poco roca...

(12) ... Já tem uma base duns... seis anus mais o menus queu to assim. Só qui agora eu to bem roca pur causa da gripe forht ... mais a minha voiz tapo muito depois da tiróide...

(16) E essi amor, essi carinhu podi transparece na voz, com certeza. A voz é que nem u dia a dia da genti... muda muitu. Tudu na genti muda...

\section{F = Fatores referidos de interferência na vida cotidiana}

\begin{tabular}{|c|c|}
\hline EXPRESSÕES -CHAVE & DISCURSO DO SUJEITO COLETIVO \\
\hline $\begin{array}{l}\text { (1) Então, a gente conseguia, i eu conseguia } \\
\text { fazê essa part ...., mais eu tava com a pressão } \\
\text { muito alta i..., comecei a me sentir } \\
\text { exageradamente gorda, senti muito cansaço... } \\
\text { (2) Eu senti a diferença da minha vida sexual } \\
\text { pra cá. Já não é queli entusiasmu mais ... Não } \\
\text { sei se é devidu a menopausa também ou é... } \\
\text { cansaço fisico também que faz dormi, muda... } \\
\text { Mas eu acredito que sim, que seja mais pelu } \\
\text { fatu da menopausa. } \\
\text { (4) ... eu me esqueço de todas as coisa que eu } \\
\text { faço, sempre assim, as veiz me lembro de dá } \\
\text { um recado, às veiz mi esqueçu... Que nem } \\
\text { meus remédio, to pensando que eu num sei } \\
\text { dize o nome pra dotora que remédio queu } \\
\text { tomo, pra pressão, essas coisa... fico ali leio, } \\
\text { pegando, mas depois quando chego eu num } \\
\text { sei... } \\
\text { (5) Quantu mais velhu, poderá parece... } \\
\text { (16) Você sabi qui até cus poblema da genti a } \\
\text { qenti aprendi... a doença, a dor.., a perda, as }\end{array}$ & $\begin{array}{l}\text { A pressão alta, o excesso de peso, a } \\
\text { menopausa, problemas de memória e atenção, } \\
\text { a idade, problemas de saúde e o cansaço } \\
\text { interferem na vida das pessoas. Podem } \\
\text { modificar a vida sexual diminuindo o } \\
\text { entusiasmo e dificultar as atividades diárias. } \\
\text { No entanto, deve-se aprender com as } \\
\text { dificuldades e tirar proveito para a vida. }\end{array}$ \\
\hline
\end{tabular}


dificuldadi ensinam a genti, tudu a genti tira um proveitu na vida... ii cu essi poblema da minha neta... a genti ta sendu assimm... menos amarga... A genti ta venu qui as coisas não é só na agressividadi, irritabilidadi, u amor qui a genti ta pondo, uma pessoa falo pra genti... às vezis nem u medicamentu qui a genti ta dandu pra ela, não leva a nada, é u amor, u carinhu, a atenção qui a genti dedica... i é uma verdadi, qui é a melhor terapia. Tudu na genti muda...

(19) E só sei quieu queria se calma, quiria se bem, quiria se assim, quiria se qui nem as otras pessoa, amorosa, eu num so calma, eu so diferenti di todus, di todu mundu achu, di todu mundu quieu conheçu... pur causa da minha cabeça... .... a outra coisa, terça-fera eu saí, fui compra um tênis, perdi u tênis... setenta real perdi no ônibus, num sei aondi, num sei si dexei mi robarem, num sei a qui aconteceu, cheguei im casa sei quieu cheguei im casa sem u tênis. Sábadu atrasadu eu fui fugi du veiu pa dança, daí qui gozadu, dai nu ônibus fui robada... robaro meu dinheru i robaru até meu cartão, até minha entrada du baile... Agora eu, saiu dá vontadi di i nu banheru, caiu um tombu, machucu u juelhu, olha aí ó u tombu quieu caí (mostrando os joelhos machucados) Ah, ta locu, a sorti minha é quieu num caí em cima du monti di garrafa quebrada qui tinha lá....

\section{Ancoragem}

$A=A$ maioria diz que a menopausa muda a vida da gente

\section{EXPRESSÕES -CHAVE}

(2) Eu não tinha essa voz grossa... Eu acho que é devido a menopausa... $\mathscr{E}$, maioria das pessoas falam... que muda $u, u$ comportamentu, muda a voiz, muda...

(6) ...muitas pessoa falo qui. quando entra na menopausa a voz muda também... ... eu acho eu num to com nenfium dessis ploblema ainda... Pode se que vai vim...
DISCURSO DO SUJETTO COLETIVO

A maioria das pessoas diz que na menopausa há mudança na voz e de comportamento. Pode ser que eu ainda vá sofrer com os problemas, além da voz engrossada.

\section{INSTRUMENTO DE ANÁLISE DO DISCURSO 1}

\begin{tabular}{|l|c|c|}
\hline $\begin{array}{l}\text { EXPRESSÕES - CHAVE Questão 4 } \\
\text { Fale um pouco sobre a sua voz na } \\
\text { menopausa. }\end{array}$ & IDÉIAS CENTRAIS & ANCORAGEM \\
\hline $1 \mathrm{E} \mathrm{E}_{\text {, eu dexei di ensaiá por causa do }}$ & (1) Sentiu diferença quando & \\
\hline
\end{tabular}




\begin{tabular}{|c|c|}
\hline $\begin{array}{l}\text { cansaço, no geral... Eu tava sintinu, né... } \\
\text { mas não sei, não dá pra mim saber se é o } \\
\text { cansaçu da voz ou no geral, o cansaçu } \\
\text { físico... acho que mais o cansaçu físicu, } \\
\text { sabe?... Porque quando a gente ta lá } \\
\text { naquele ensaio, a gente não sente cansaçu, } \\
\text { você pode ficar uma, duas, treis horas lá } \\
\text { que num..., não vê u tempu passa, é } \\
\text { uma coisa maravilhosa. Ah sim, eu sinto } \\
\text { que minha voz ficó assim parece que ta } \\
\text { mais grossa, num sei... às vezes eu to lá, } \\
\text { porque eu sempre to co a minha televisão } \\
\text { ligada, né... e tem aquele programa do } \\
\text { missionário Hebert Soares ... é muito bom, } \\
\text { sabi?... então ali tem pregações, tem hinus, } \\
\text { então quandu ta cantando eu também to } \\
\text { cantando junto, sabi? (rindo)...... Eu sinto } \\
\text { diferença quando canta, quandu falo... } \\
\text { apesar que eu achei que minha voz fico } \\
\text { assim... não sei se roca ou... diferente um } \\
\text { pouco do que era antes, nesse tempo aí, } \\
\text { nesse periodo... não sei se é porque a } \\
\text { gente fica sem fazé ensaio, né... purque } \\
\text { um ensaio ajuda bastante, né... Então, .... } \\
\text { por causa daquele problema, } \text { um } \\
\text { pouquinho, eu acho... não sei se é devido } \\
\text { aquele ardume, aquela secura da minha } \\
\text { garganta, né? não, não chega a ser um } \\
\text { calo, porque calo nas cordas vocais é } \\
\text { uma coisa bem diferente, né... mais... eu } \\
\text { acho que alguma coisa atrapalhó, tem } \\
\text { alguma coisa a vê, sim, principalmente } \\
\text { assim, se eu me emociono ou se às veiz eu } \\
\text { tenho que chama a atenção dos meus } \\
\text { netos e se eu falo uma, duas, treis vezes, } \\
\text { na terceira vez dá pigarru, sabi?... É esse, } \\
\text { a diferença que eu to sentindu, antes eu } \\
\text { não tinha issu. }\end{array}$ & $\begin{array}{l}\text { canta e fala: a voz está talvez } \\
\text { um pouco rouca, mais grossa } \\
\text { e atribui à falta de ensaio e à } \\
\text { ardência e secura da } \\
\text { garganta. } \\
\text { A } \\
\text { (2) Não que seja "calo" vocal, } \\
\text { mas que algo atrapalhou, } \\
\text { porque se fica emocionada ou } \\
\text { se seguidamente precisa } \\
\text { chamar a atenção dos netos, } \\
\text { fica com pigarro e isso não } \\
\text { acontecia antes da } \\
\text { menopausa. Relata que deixou } \\
\text { de cantar, pois, apesar de não } \\
\text { sentir o tempo passar } \\
\text { enquanto ensaiava, estava } \\
\text { percebendo muito cansaço } \\
\text { físico. Tem assistido ao } \\
\text { programa de um missionário } \\
\text { na televisão e acompanha os } \\
\text { cânticos. } \\
\text { C }\end{array}$ \\
\hline $\begin{array}{l}\text { 2E A voz muda, muda bastant vai } \\
\text { engrossando mais a voz, né... Num fica } \\
\text { mais aquela voz feminina, que as veiz a } \\
\text { gente até sente mal de conversa, né?... A } \\
\text { gente sent' que, que a voz engrosso bem } \\
\text { mais..Eu achu qui é ... se muda alguma } \\
\text { coisa na pessoa, muda issu... é.... num tem } \\
\text { mais aquela voz feminina, aquela voz mais } \\
\text { aguda, num é aquela voz fina. }\end{array}$ & $\begin{array}{l}\text { (1) Ela acha que a voz após a } \\
\text { menopausa mudou bastante, } \\
\text { tornando-se grossa (grave). } \\
\text { A } \\
\text { (2) não é mais uma voz } \\
\text { feminina, aguda e fina. } \\
\text { C }\end{array}$ \\
\hline $\begin{array}{l}\text { 3E (rindo) Aa Então essa voz, é da } \\
\text { menopausa, é? Eu num sabia dissu, achei } \\
\text { que era pur cigarru... Mudo bastante a }\end{array}$ & $\begin{array}{l}\text { (1) Pela pergunta chega à } \\
\text { conclusão que a mudança na } \\
\text { sua voz é devido também à }\end{array}$ \\
\hline
\end{tabular}


minha voz estis anus pra cá... É as vezes eu atendo... o telefone toca daí eu atendo, dai a pessoa acha que é um homem que ta falanu... Fazé o que, né, não tem como mudá, né? ... Será que tem? (rindo) Então vamu apela pra mudá, né? .... me incomoda ... Aí... sei lá várias coisas... se vê, mesmo... talvez purque até vô na igreja, eu tenho problema, você vê, de voz assim pra canta um hinu. Eu não tinha, você vê, ele me trava, às vezis me tranca, já a voz grossa... daí..., eu não tinha isso aí, agora...

4E Achu que continua a mesma coisa. Num sei respondé como é a minha voz.

$5 E$ Ah, de novinha deve te... eu senti diferença... Mas de antes da menopausa pra gora, eu num senti diferença. É eu tenho a voz muitu forti. Voz forte é quando você qué dá um grito bem alto, qui eli sai a voz limpa e sai grito forte... eu consigo fazé isso, até mais que genti mais nova do que eu. Ah, a gente vê que sim, né?... as otra pessoa você prestanu tenção você percebi que vai mudano, mais eu já por isso já vo adiantando, né... Daí eu sei que isso puderá contecé, eu já... quero evita que acunteça cumigo. Faço massage, se preparo e quando gente vai fala, abri bem a garganta... não dexá i trancandu. Eu leiu revista... escutu a reportagem... eu vi a minha a mãe, eu vi pessoas mais velha, eu já vi que tem pessoas mais velha que vai... as vezes mesmu quando a gente tava na no grupo na igreja que ia cantá, tem pessoas que a gente quiria voz... pessoas mais velha, eu sentia queles apertava garganta... Então eu já vo preparano a minha... eu sei que fazé a que é bom de fazé... num vo espera tá precisano já pra fazé, né?... Já vo evitá que aconteça ... Quando aperta a garganta ela sai uma voz apertada, né... Uma voz chiada... não sai aquela voz limpa, voz forte, se vê que tem parece que tem alguma coisa engasgada na garganta...

6E Hoji eu to achano ela mais cheia, assim pareci a voz ta mais... grossinha... num sei, eu acho qué devido a minha garganta menopausa e não só ao cigarro. Sua voz é confundida com voz de homem ao telefone e gostaria de mudar porque a incomoda,

(2) principalmente quando vai cantar os hinos na Igreja, pois está grossa e ainda trava, tranca (a voz), sensações que não tinha antes da menopausa. A

Acha que a voz continua a mesma

(1) Sentiu diferença de quando era nova para agora, A

(2) mas não de antes e depois da menopausa.

B

(3) Acha que tem uma voz muito forte, que pode gritar alto que ela sai limpa e mais forte do que de pessoas mais novas. Para evitar alterações faz massagens, se prepara e quando vai falar abre bem a garganta, não deixando trancar.

(4) Lê revistas, escuta reportagens sobre o assunto e convive com pessoas mais velhas, nas quais presta atenção, percebendo como a voz vai mudando, pois elas apertam a garganta, a voz sai chiada, não é limpa nem forte e parece ter algo engasgado. D

Observa que, particularmente hoje, a sua voz está mais 
mesmo. Até quieu... eu ia fala... quem ove..., mais quem escuta eu fala ai, quem vai ovi a gravação, fala " nossa que mulher isquisita, que muié mais feia, oh a voz dessa mulher", eu achu... muito feia.. qué dize, eu num so tão bunita, num so bunita, mais também num so tão feia, mais essa voz ai parece daquelas muié muito fea dimais...

7E Eu acho que eu fiquei muito sensivel com a menopausa... Dor eu sei qui eu num tinha, agora to tendo... Qui nunca num duia antes... Tontura..., eu nunca senti antes, to tendo tontura, mas também num to tomando nenhum medicamento queu acho qui ta certo ainda... pra mim melhora, purque eu não me sintu uma pessoa duente, eu acho que se eu toma um remédio que me faça bem, eu vo fica boa, purque trabalha qui nem eu trabalho... uma pessoa doent num trabalha qui nem eu trabalho ... a voz teria que melhora, eu acho... Teim essa fraqueza, essi cansaçu... Ahh, às vezis eu tenho choradera de novo eu achu queu to entrano em depressão..., eu não tinha a qua.. três mesis atrás eu num dava esses tipo de coisa.

8E Não, pur cause quieu acho assim: sei sé purque a genti fica, a genti dá uma ansiedadi na genti, a veis quanu a genti fica deitado, ta durminu, acorda... "Será, meu Deus, queu to boa, será quieu vo se...qui vo te vố te uma melhora, será quiu vo fica melhor assim". Eu achu qui tem hora quieu mesmu sintu queu to, u momentu queu tô falano baxo, cumeçu alto, eu sintu aquela ruindadi assim, daí eu peço pra Deus, "oh Deus me ajuda queu num era assim"... Então..., eu sei queu to passanu pur algum pobrema, então, issu aí to passanu mesmu, to tem... ainda mais a genti qui, qui mora sozinha, num tem cum quem cunversa, então, é pior pra genti ainda, tem hora queu cunverso até sozinha, dendi casa daí, mais faze o que... A genti tem que passa por issu aí...A voz era diferenti. Eu num sei.. purque u motivu... Pur cause qui.., sei lá si a genti.. vai ficanu velha, ou sei lá o que qui conteci, aguma coisa ni mim aconteceu di a minha voiz, eu cheia, mais grossa devido ao problema de garganta, mas que quem escutar a gravação vai achar que é de uma mulher esquisita, muito feia, porque a voz conduz a essa representação, apesar dela não se considerar tão bonita nem tão feia.

Pondera que ficou muito sensível com a menopausa. Dores, tontura, fraqueza, cansaço, choradeira que atribui à depressão são sensações que não tinha até recentemente. Ainda não está tomando nenhuma medicação e, apesar de não considerar-se doente, pois trabalha muito, acha que deve tomar algum remédio que a faça sentir-se melhor, inclusive na voz.

C

(1) Não sabe se é por causa da ansiedade, porém às vezes está dormindo e acorda pensando e pedindo a Deus para melhorar, pois está passando por problemas de saúde, e como mora sozinha, não tem com quem conversar, é pior ainda.

C

(2) Sente a voz diferente, não sabendo se era mais fina ou mais grossa, e acha que o motivo da mudança pode ser a velhice.

A 


\begin{tabular}{|c|c|c|}
\hline $\begin{array}{l}\text { pensei qui eu tinha a voiz deferenti assim, } \\
\text { mas quando eu era mais nova. Ou era mais } \\
\text { fina ou era mais.., mais grossa... Então..., } \\
\text { achu assim. }\end{array}$ & & \\
\hline $\begin{array}{l}\text { 9E Ah, eu achu qui modifico muito pocu, } \\
\text { mas eu achu qui mudo alguma coisa. Não, } \\
\text { eu achu qui não mudo assim pra pior, } \\
\text { não..., achu qui não. Ah, eu achu quiii, de } \\
\text { repenti a genti chega numa idad qui a } \\
\text { genti sabe mais.. os valores das coisas... } \\
\text { Qui antes os valores era um i agora a genti } \\
\text { acha qui u valor é otru... Ai eu achu qui } \\
\text { tudu issu a genti acaba transmitindo na } \\
\text { voz.... Qui a gente senti assim... é... valor } \\
\text { diferenti... a genti consegui medi as coisa } \\
\text { assim... di uma outra forma... Que a genti } \\
\text { acha... vê a vida assim um pocu diferenti } \\
\text { com a idadi qui a genti ta... Qui antis u que } \\
\text { não era muitu di valorizadu pra mim, hoji já } \\
\text { valorizu mais... Eu achu qui é issu... }\end{array}$ & $\begin{array}{l}\text { (1) Conjectura que a voz } \\
\text { mudou muito pouco e para } \\
\text { melhor. } \\
\text { A } \\
\text { (2) Chegou em uma idade que } \\
\text { sabe mais os valores das } \\
\text { coisas, que mede tudo de } \\
\text { forma diferente e vê a vida } \\
\text { mais valorizada e que essa } \\
\text { transformação é transmitida } \\
\text { na voz. C }\end{array}$ & \\
\hline $\begin{array}{l}10 \mathrm{E} \text { Num percebi si realmenti houvi algu, } \\
\text { assim num atinu assim, num cunsigu } \\
\text { dicerni si realmenti houvi. }\end{array}$ & $\begin{array}{l}\text { Não percebe nem discerne se } \\
\text { houve alguma mudança na } \\
\text { voz durante e após a } \\
\text { menopausa. B }\end{array}$ & \\
\hline $\begin{array}{l}11 \mathrm{E} \text { Não! Eu num, não.., sabi quieu num } \\
\text { coloqueei.., num ponhei essi nu } \\
\text { pensamentu, eu não... Eu creiu qui é igual } \\
\text { era antis. }\end{array}$ & $\begin{array}{l}\text { Crê que seja igual à voz que } \\
\text { tinha antes da menopausa. B }\end{array}$ & \\
\hline $\begin{array}{l}\text { 12E Num sinti deferença, num sinti purque } \\
\text { eu tava cum aquele pobrema di voiz... Eu Eu } \\
\text { tenhu uma immã qui depois da menstruação } \\
\text { ela fico bem roca tamém. Depois qui veio... ela } \\
\text { deu um pobrema assim quela, efis fafum qui fooi uuma } \\
\text { chuva qui efa tomo ela fico bem roca, duma chuva qui } \\
\text { ela tomo... Aí ela fico bem roca, mais fico } \\
\text { roca pra sempre, nunca mais trato... Não, } \\
\text { quando veiu, é ... é quandu desceu a } \\
\text { menstruação, intão a gent' tinha aquele } \\
\text { custume di nãão banha cabeça... e ela } \\
\text { tomo aquela chuva duma veiz, aí ela roco. } \\
\text { Agora num fala qui foi issu, num sei ... }\end{array}$ & $\begin{array}{l}\text { (1) Não sentiu diferença } \\
\text { porque já estava com } \\
\text { problemas na voz (por causa } \\
\text { da tireóide). B } \\
\text { (2) Relata sobre uma irmã } \\
\text { que, depois da menarca, } \\
\text { quando estava menstruada, } \\
\text { tomou chuva, e ficou rouca } \\
\text { para sempre. Pensa que pode } \\
\text { ser porque tinham o costume } \\
\text { de não lavar a cabeça estando } \\
\text { menstruada, mas não tem } \\
\text { certeza se a explicação é } \\
\text { verídica. }\end{array}$ & $\begin{array}{l}\text { Menstruada, tomar } \\
\text { chuva deixa rouca. } \\
\text { A }\end{array}$ \\
\hline $\begin{array}{l}13 E \text { Ah, ta meio diferenti... Di quandu eu } \\
\text { era mais jovem assim... Notu qui a genti } \\
\text { vai ficanu di mais idadi... di certu vai } \\
\text { modificanu, sei lá... Num sei, voiz di genti } \\
\text { novu é mais, sei lá, mais eleganti. agora a } \\
\text { genti vai ficanu veia a voiz pareci qui fica } \\
\text { meio diferenti... Ah, eu mi sintu assim... }\end{array}$ & $\begin{array}{l}\text { (1) Presume que houve } \\
\text { diferença na voz depois da } \\
\text { menopausa, que esta ficou } \\
\text { menos elegante. A } \\
\text { (2) Nota que conforme vai } \\
\text { ficando com mais idade, a voz } \\
\text { fica diferente. C C }\end{array}$ & \\
\hline
\end{tabular}




\begin{tabular}{|c|c|}
\hline $\begin{array}{l}14 E \text { Ah, num tenhu comu fala, u qui fala... } \\
\text { Não, achu qui não teve modificação. Eu } \\
\text { achu que desdi minina até agora eu achu } \\
\text { qui, sei lá, num mudei não. Nu meu } \\
\text { pensamentu... nu meu vive, achu qui não... }\end{array}$ & $\begin{array}{l}\text { Chega à conclusão que não } \\
\text { houve mudança em sua voz } \\
\text { durante toda a vida. } \\
\text { B }\end{array}$ \\
\hline $\begin{array}{l}\text { 15E Parece qui fico assim uma voz mais } \\
\text { envelhecida... assim, sei lá... Igual de uma } \\
\text { pessoa de mais idade, o jeitu di fala já nấo } \\
\text { é qui nem uma pessoa mais jovem... } \\
\text { Porque ce sabi, quandu às vezis assim... } \\
\text { conversava cas pessoa assim por telefone... } \\
\text { pessoas assim qui não conhecem a genti, } \\
\text { chamava a genti de você... agora di uns } \\
\text { tempu pra cá, tudo é senhora, senhora, dá } \\
\text { a impressão qui... pelu tom di voz qui eu } \\
\text { envelheci bastanti... Ce pega o telefone é } \\
\text { senhora, primeru era você... agora é } \\
\text { senhora... Puxa, olha.... Agora já, u u } \\
\text { assuntu já muda totalmente... já não ế qui } \\
\text { nem quanu a genti tem menas idade... }\end{array}$ & $\begin{array}{l}\text { (1) Sugere que ficou com o } \\
\text { tom da voz mais envelhecido, } \\
\text { (2) como de uma pessoa com } \\
\text { mais idade em que o jeito de } \\
\text { falar e o assunto são } \\
\text { diferentes de quando se tem } \\
\text { menos idade. Percebeu isso } \\
\text { quando passaram a chamá-la } \\
\text { de senhora no telefone sem } \\
\text { conhecê-la. }\end{array}$ \\
\hline $\begin{array}{l}\text { 16E Não. Até o contrário porque falaram } \\
\text { quieu ta, eu comecei tomar Estrodon P... e } \\
\text { ali na bula logicamente fala... Tinha uma } \\
\text { colega minha quiela tevi uns poblema } \\
\text { seríssimu, ela mudo a voz dela, queria qui } \\
\text { ce visse, mudo, até hoje é mudada, a voz } \\
\text { dela num é aquilu. Ela fico cuma voz de } \\
\text { homem, ce credita? Ela tem, tinha pêlo } \\
\text { tudu assim, assim no rosto dela, assim } \\
\text { incrivel... Eu tive um pouco disso, mas não } \\
\text { no rosto, nas pernas... aqui embaixo um } \\
\text { pouquinho assim... muito pouco... Minha } \\
\text { voz continuou a mesma, graças a Deus, } \\
\text { porque pela bula que você vê do Estrodon } \\
\text { P ali ela causa os efeitos colaterais ali... } \\
\text { seríssimus... ...essa minha colega, nós } \\
\text { trabalhávamos juntus te hoji a genti tem } \\
\text { amizade, ela mudo completamenti a voz } \\
\text { dela. Ela tinha que faze depilação no } \\
\text { rosto.... de tantu em tantu tempu... agora } \\
\text { não, porque agora com a idadi já vai } \\
\text {..amortecenu um poucu... mas a voz dela } \\
\text { continua mema coisa. .... Eu não, minha } \\
\text { voiz não mudo nada.... nem pra canta. } \\
\text { Claru qui eu não tenhu aqueelii.. queli } \\
\text { preparu todu, mais eu cantu. Inclusivi a } \\
\text { genti ce sabi qui quando eu me operei, a } \\
\text { primera veiz quieu fiz a operação de ováriu, } \\
\text { eu tava saindu da anestesia iscutei uma }\end{array}$ & $\begin{array}{l}\text { (1) Verifica que sua voz não } \\
\text { mudou nada nem para cantar, } \\
\text { mesmo não tendo preparo } \\
\text { para isso. } \\
\text { B } \\
\text { (2) Recorda-se de uma colega } \\
\text { que tomou a mesma } \\
\text { medicação que ela, após a } \\
\text { cirurgia (histerectomia e } \\
\text { ooforectomia) e ficou com voz } \\
\text { de homem, com pêlos no } \\
\text { rosto precisando fazer } \\
\text { depilação, porém com ela não } \\
\text { aconteceu nada. } \\
\text { D Dar. pós- } \\
\text { (3) Relata que no pós } \\
\text { cirúrgico, ainda estava um } \\
\text { pouco anestesiada e escutou } \\
\text { a prima, que é enfermeira, } \\
\text { falando para seu companheiro } \\
\text { que ela ficaria mais gorda e } \\
\text { perderia a sexualidade. Ficou } \\
\text { abalada porque fazia poucos } \\
\text { meses que os dois estavam } \\
\text { juntos. Depois percebeu que, } \\
\text { independente de comer mais }\end{array}$ \\
\hline
\end{tabular}


prima minha quiela éé, te hoji ela é enfermera... ela falo pro meu companheru, qui nóis já se conhecia nessi tempu, "só vai ter um pormenor: vai ficar mais gorda (qui realmenti nunca mais pudi voltar u meu pesu quieu pesava quarenta e dois) ... ela vai fica mais gorda purque é qui nem um porco castradu (mi lembru tão bem quiela falo issu) e otra coisa, ela vai perde a sexualidadi... ... Aquilu me abalo, porque nós estávamos, nós fazia pocos mesis qui se tinha se conhecidu, eu e eli... Aquilu, mais eu anestesiada, saindu da anestesia iscutei ela fala... "bandida, falo issu pra eli", sabi. Depois eu xinguei ela... depois dias depois eu xinguei ela. Aí elaaa... não mais nada dissu aconteceu... Aconteceu deu fica gorda, aumento o pesu e não tem como reverte, sieu como poco fico mema coisa, sieu como bem eu fico a mema coisa. Não tem... é engraçadu.. Podi se qui cum ... caminhada, essas coisa qui eu sempri queru faze i nunca dá, podi se quieu voltu um poquinhu menus... Na lanchoneti, nu tempu quieu trabalhava, eu comecei a só toma muitu líquidu... líquidu que dize água mesmu, nem refrigeranti... qui tinha muita coisa ali, muita gordura, muita coisarada, intão dexei de ladu i comecei a toma muitu líquidu, hora quieu tava lá, quieu fazia oitu horas, tinha dias quieu fazia dezesseis horas... Intão, eu aí imagreci, imagreci, magrici, magrici mesmu... Tava até feiu, mais depois eu fui voltandu ao normal, daí eu fiquei muitu magra, as ropa caindu, até minha gerenti falo assim "ai... você ta tão feia assim, você tem u corpu tão bunitu...", qui eu tenhu sempri quadril... "qui ta

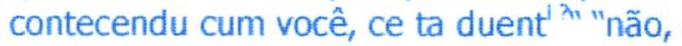
não, a única coisa qui num to comendu essas ... bobagerada ai ${ }^{\prime \prime}$ qui, sabi, saturada "i tomanu bastanti líquidu". Daí eu vi que tava meiu... Ai comecei novamente.. não cume quelas bobagerada, mais..leva um lanche de casa, um pão, dois i comecei novament a ingorda e no percu. Mais u contrário ta tudu bem.

17E Ah, modifico um poco. Num sei se é pur causa du calorão... ... mais modifico um poco a minha voiz... Depois otra, a genti fica muitu nervosa... u calorão também ou menos, como não faz exercícios porque nunca dá tempo, não consegue diminuir seu peso, mas que não perdeu a sexualidade. Quando trabalhava na lanchonete parou de comer os salgados que eram muito gordurosos e só tomar água trabalhando oito ou até dezesseis horas no dia, e emagreceu muito, as roupas ficaram todas caindo. Até a gerente achou que ela estava doente, porque ficou feia. Daí, passou a levar um lanche de casa, engordou e não emagreceu mais. c
(1) Refere mudança na voz: a voz era mais fina e engrossou ficando rouca. Notou diferença quando canta. 


\begin{tabular}{|c|c|}
\hline $\begin{array}{l}\text { ataca muitu us nervu da genti. A minha } \\
\text { voiz era mais fina... deu uma engrossada. } \\
\text { Eu gostu di canta. Antis era mais fina } \\
\text { agora ta mais grossa... ta mais, fico mais.. } \\
\text { roca... Então, foi aondi eu achei diferença... } \\
\text { Quandu a genti canta a genti nota } \\
\text { diferença. }\end{array}$ & $\begin{array}{l}\text { A } \\
\text { (2) Não sabe se é por causa } \\
\text { do calorão, que a deixa muito } \\
\text { nervosa. } \\
\text { C }\end{array}$ \\
\hline $\begin{array}{l}\text { 18E Quieu mi lembru não, nem sei comu } \\
\text { era a minha voz antis... num sei não... Eu } \\
\text { achu qui não, achu qui continua senu a } \\
\text { mesma. } \mathrm{Na} \text { minha opinião achu qui } \\
\text { continua a mesma... }\end{array}$ & $\begin{array}{l}\text { (1) Acha que a voz continua a } \\
\text { mesma. B } \\
\text { (2) e não sabe como era sua } \\
\text { voz antes da menopausa. C }\end{array}$ \\
\hline $\begin{array}{l}\text { 19E Nunca consegui canta, nunca. Nem di } \\
\text { mocinha. Eu cantu, mais é tudu desafinadu } \\
\text { i tem uma coisa qui incomoda. Sempri, } \\
\text { desdi moça durmu fazenu (faz sons de } \\
\text { roncos no nariz e garganta) a noiti intera } \\
\text { fazenu issu. Ela mando faze exami di } \\
\text { sangui i no meu ixami di sangui hoji eu vo } \\
\text { vê a tiróidi. }\end{array}$ & $\begin{array}{l}\text { Relata que nunca conseguiu } \\
\text { cantar, nem de mocinha: é } \\
\text { muito desafinada. Porém, o } \\
\text { que a incomoda são os sons } \\
\text { que faz enquanto dorme. Fez } \\
\text { exames de sangue e hoje iria } \\
\text { ver com a médica se está com } \\
\text { problemas de tireóide. C }\end{array}$ \\
\hline $\begin{array}{l}\text { 20E A minha voz sempre foi a mesma. Eu } \\
\text { gostu da minha voz. }\end{array}$ & $\begin{array}{l}\text { Entende que sua voz foi } \\
\text { sempre a mesma. } \\
\text { B }\end{array}$ \\
\hline $\begin{array}{l}21 \mathrm{E} \text { A voiz continua a mesma. Eu achu } \\
\text { quieu era assim, purque eu sempri gostei di } \\
\text { fala calma assim, num pricisu di grita nem } \\
\text { nada... }\end{array}$ & $\begin{array}{l}\text { (1) Reconhece que a voz } \\
\text { continua a mesma após a } \\
\text { menopausa B } \\
\text { (2) e que isso se deve ao fato } \\
\text { de falar calmamente, sem } \\
\text { precisar gritar. C C }\end{array}$ \\
\hline $\begin{array}{l}22 \mathrm{E} \text { Eu achu que não, achu que não... } \\
\text { Continua, continua como era antis. Não } \\
\text { senti nenhum tipo di mudança... }\end{array}$ & $\begin{array}{l}\text { Opina que a sua voz continua } \\
\text { como antes da menopausa, } \\
\text { que não sentiu nenhuma } \\
\text { mudança. B }\end{array}$ \\
\hline $\begin{array}{l}\text { 23E Eeeu acchu. Fico mais grossa... Era } \\
\text { mais fina... Até nu telefoni, às veiz, certas } \\
\text { pessoa estranha... "Cum quem qui eu to } \\
\text { falanu?", "Ah, com ***." "Ah, ta coa voz } \\
\text { tão estranha.." Eu achu qui mudo, eu achu } \\
\text { qui mudo sim. }\end{array}$ & $\begin{array}{l}\text { (1) Compreende que sua voz } \\
\text { mudou, ficou mais grossa, A } \\
\text { (2) e que até no telefone as } \\
\text { pessoas estranharam. C }\end{array}$ \\
\hline $\begin{array}{l}\text { 24E Não, eu notei nu rostu, to inrugandu, } \\
\text { eu não tinha issu aqui (mostra em torno da } \\
\text { boca, com a mão) di poquinhu tempu pra } \\
\text { cá eu comecei, minha pele ta flácida, na } \\
\text { voz não, na voz não senti... }\end{array}$ & $\begin{array}{l}\text { (1) Notou mudanças no rosto } \\
\text { que está enrugando e ficando } \\
\text { flácido em pouco tempo, C } \\
\text { (2) mas na voz não. }\end{array}$ \\
\hline
\end{tabular}




\begin{tabular}{|c|c|}
\hline $\begin{array}{l}\text { força um poco pra fala.. purque eu nunca } \\
\text { fui di conversa altu mesmu... a genti já é } \\
\text { mai di familia di conversa mais baxu, mais } \\
\text { eu sintu assim qui tem hora quieu tenhu } \\
\text { qui força um poco assim pra fala... Achu } \\
\text { qui é meu tom di voiz ta dimi, ta ficanu } \\
\text { mais rocu, mais assim baxu... tem hora qui } \\
\text { força, i quanu eu to meia deprimida é pior } \\
\text { ainda... Eu sintu issu, eu sintuuu qui forçu } \\
\text { bastanti, depois quieu entrei na } \\
\text { menopausa. }\end{array}$ & $\begin{array}{l}\text { modificado depois que entrou } \\
\text { na menopausa e que agora } \\
\text { precisa forçar mais para falar, } \\
\text { que o tom da voz está ficando } \\
\text { mais baixo, mais rouco, A } \\
\text { (2) e piora quando está } \\
\text { deprimida. Sempre foi de falar } \\
\text { em baixa intensidade, como a } \\
\text { família. } \\
\text { C }\end{array}$ \\
\hline $\begin{array}{l}\text { 26E É, eu achu qui é depois da menopausa } \\
\text { qui ela fico mais, parece... Tem hora qui } \\
\text { fico assim bem fanhosa... }\end{array}$ & $\begin{array}{l}\text { Dispõe que depois da } \\
\text { menopausa a voz ficou mais } \\
\text { fanhosa } \quad \text { A }\end{array}$ \\
\hline $\begin{array}{l}27 E \text { Eu acho que sim. É é, como eu vo dize, } \\
\text { eu conversava mais... agora to mais assim, } \\
\text { prefiro fica assim... sem fala. }\end{array}$ & $\begin{array}{l}\text { A mudança notada é que } \\
\text { conversava mais e agora } \\
\text { prefere ficar calada. A }\end{array}$ \\
\hline $\begin{array}{l}28 \mathrm{E} \text { Não, pelu quieu sintu assim, não... A } \\
\text { minha voiz é sempre assim... Não so de } \\
\text { muita..., muito tempu di conversa, si } \\
\text { conversa dimais, começa, ai já dá dor nu } \\
\text { corpu da genti... }\end{array}$ & $\begin{array}{l}\text { (1) Pelo que sente a voz } \\
\text { continua a mesma, B } \\
\text { (2) que nunca foi de conversar } \\
\text { muito, pois isso dá dor no } \\
\text { corpo. C C }\end{array}$ \\
\hline $\begin{array}{l}\text { 29E Eu achu qui sim. Dá a impressão assim } \\
\text { qui ela fecha ma um pocu... Mais fechada, } \\
\text { assim, mais éé, mais forçada pra fala. Essa } \\
\text { foi a diferença quieu notei. Qui ela é meia } \\
\text { roca (quando fazia tratamento para a } \\
\text { tireóide), tem veiz qui é meia roca, tem } \\
\text { veiz qui não. }\end{array}$ & $\begin{array}{l}\text { Nota que a voz ficou diferente, } \\
\text { instável, às vezes rouca, às } \\
\text { vezes não, com a impressão } \\
\text { de estar mais fechada, mais } \\
\text { forçada para falar. } \\
\text { A }\end{array}$ \\
\hline $\begin{array}{l}\text { 30E Mudo um poquinhu, sim, num sei } \\
\text { pareci quieu andu mais assim, mais roca, di } \\
\text { veiz im quandu pareci assim, quando eu } \\
\text { conversu um poquinhu demais, pareci qui, } \\
\text { que eu ficu mais roca assim, eu fiquei cum } \\
\text { mais facilidadi di fica roca, é issu ai. É } \\
\text { mesma coisa qui era antis, cum mais } \\
\text { facilidade de fica roca, é. Eu fui nu médicu } \\
\text { da depressão, eli dissi qui u nervosismu eli } \\
\text { é em parte por causa da menopausa } \\
\text { tamem... Só qui daí eu falei pra eli assim } \\
\text { "dotor eu no to tomanu remediu, eu to } \\
\text { usanu us adesivu"... Eu não sei porque qui } \\
\text { a médica não mideu o remédio lá, mando } \\
\text { gruda us adesivu... eu achu qui é porque } \\
\text { protegi u fígadu, a genti já tomo bastanti } \\
\text { remediu... daí quantu menus melhor... Eu } \\
\text { tinha já essas informações a respeito da }\end{array}$ & $\begin{array}{l}\text { (1) Concebe que houve uma } \\
\text { pequena mudança e que está } \\
\text { com facilidade de ficar rouca: } \\
\text { basta conversar um pouco a } \\
\text { mais. } \\
\text { A } \\
\text { (2) O médico psiquiatra que a } \\
\text { trata da depressão havia } \\
\text { alertado a respeito de alguns } \\
\text { sintomas que se exacerbam na } \\
\text { menopausa e inclusive de } \\
\text { mudanças que poderiam } \\
\text { ocorrer na voz. Relata a ele } \\
\text { que não toma remédios, } \\
\text { porém, que está em } \\
\text { tratamento com hormônios } \\
\text { por adesivos, e acha que é } \\
\text { para proteger o fígado, pois }\end{array}$ \\
\hline
\end{tabular}


menopausa e até da voz pelu médicu da depressão... usou muitos medicamentos.

C

\section{INSTRUMENTO DE ANÁLISE DO DISCURSO 2}

\section{Questão 4: Fale um pouco sobre a sua voz na menopausa}

$$
\mathbf{A}=\text { Houve mudanças na voz }
$$

\begin{tabular}{|c|c|}
\hline EXPRESSÕES -CHAVE & DISCURSO DO SUJEITO COLEIIVO \\
\hline $\begin{array}{l}\text { (1) ... mas não sei, não dá pra mim saber se } \\
\text { é o cansaçu da voz ou no geral, o cansaçu } \\
\text { físico... Assim, eu sinto que minha voz fico } \\
\text { assim parece que ta mais grossa, num sei.. } \\
\text {... Eu sinto diferença quando canta, quandu } \\
\text { falo... apesar que eu achei que minha voz } \\
\text { fico assim é... não sei se roca ou... diferente } \\
\text { um pouco do que era antes, nesse tempo aí, } \\
\text { nesse periodo... não sei se é devido aquele } \\
\text { ardume, aquela secura da minha garganta, } \\
\text {... e se eu falo uma, duas, treis vezes, na } \\
\text { terceira vez dá pigarru... É esse, a diferença } \\
\text { que eu to sentindu, antes eu não tinha issu. } \\
\text { (2) A voz muda, muda bastant', vai } \\
\text { engrossando mais a voz... Num fica mais } \\
\text { aquela voz feminina, que as veiz a gente até } \\
\text { sente mal de conversa... A gente sent' que, } \\
\text { que a voz engrosso bem mais... Eu achu qui } \\
\text { muda... ...se muda alguma coisa na pessoa, } \\
\text { muda issu... } \\
\text { (3) ele me, me trava, às vezis me tranca, já a } \\
\text { voz grossa......, eu não tinha isso ai agora. } \\
\text { (8) A voz era diferenti. ... eu pensei qui eu } \\
\text { tinha a voiz deferenti assim, mas quando eu } \\
\text { era mais nova. Ou era mais fina ou era } \\
\text { mais... mais grossa... } \\
\text { (9) Ah, eu achu qui modifico muito pocu, } \\
\text { mas eu achu qui mudo alguma coisa. Não, eu } \\
\text { achu qui não mudo assim pra pior, não.... } \\
\text { achu qui não. } \\
\text { (13) Ah, ta meio diferenti... Di quanu, } \\
\text { quandu eu era mais jovem assim... Num sei, } \\
\text { voiz di genti novu é mais, sei lá, mais } \\
\text { eleganti... } \\
\text { (15) Parece qui fico assim uma voz mais } \\
\text { envelhecida..., sei lá... } \\
\text { (17) Ah, modifico um poco. ... A minha voiz } \\
\text { era mais fina... deu uma engrossada. Eu } \\
\text { gostu di canta. Antis era mais fina i agora ta } \\
\text { mais grossa... fico mais.. roca... Então, foi }\end{array}$ & $\begin{array}{l}\text { Se há alguma coisa que muda na pessoa } \\
\text { depois da menopausa é a voz; a voz muda } \\
\text { bastante, dá para sentir a diferença para } \\
\text { cantar e para falar. Fica um pouco diferente } \\
\text { de quando era jovem: voz de gente nova é } \\
\text { mais elegante, não sei se mais fina ou mais } \\
\text { grossa. Agora ficou uma voz mais } \\
\text { envelhecida, que vai engrossando, às vezes } \\
\text { rouca, às vezes não, porém mais travada, } \\
\text { trancada. Sinto que tenho que forçar para } \\
\text { falar, pois o tom está mais baixo, mais rouco, } \\
\text { parece mais fanhosa, dá a impressão de mais } \\
\text { fechada. Não sei se é devido ao cansaço } \\
\text { fisico ou da voz, à ardência e secura da } \\
\text { laringe, ou pigarro, mas não é mais feminina. } \\
\text { Eu não tinha isso antes da menopausa, por } \\
\text { isso acho que modificou, pois era mais fina e } \\
\text { agora às vezes a gente sente mal de } \\
\text { conversar; parece que se conversa demais } \\
\text { fica mais rouca, ou estou com mais facilidade } \\
\text { de ficar rouca. Então, eu conversava mais, } \\
\text { mas agora prefiro ficar calada. No entanto, } \\
\text { para alguns, a mudança não é para pior. }\end{array}$ \\
\hline
\end{tabular}


aondi eu achei diferença... Quandu a genti canta a genti nota diferença.

(23) Eeeu acchu. Fico mais grossa... Era mais fina... Eu achu qui mudo, eu achu qui mudo sim.

(25) Modifico. Eu sintu assim quieu tenhu di força um poco pra fala.. Achu qui é meu tom di voiz ta dimi, ta ficanu mais rocu, mais assim baxu, ...tem hora qui força, ... Eu sintu issu, eu sintuuu qui forçu bastanti, depois quieu entrei na menopausa.

(26) É, eu achu qui é depois da menopausa qui ela fico mais, parece.... Tem hora qui fico assim bem fanhosa...

(27) Eu acho que sim. É é, como eu vo dize, eu conversava mais, sabi, agora to mais assim, prefiro fica assim... sem fala.

(29) Eu achu qui sim. Dá a impressão assim qui ela fecha ma um pocu... Mais fechada, assim, mais éé, mais forçada pra fala. Essa foi a diferença quieu notei. Qui ela é meia roca (quando fazia tratamento para a tireóide), tem veiz qui é meia roca, tem veiz qui não.

(30) Mudo um poquinhu, sim, num sei pareci quieu andu mais assim, mais roca, di veiz im quandu pareci assim, quando eu conversu um poquinhu demais, pareci qui, que eu ficu mais roca assim, eu fiquei cum mais facilidadi di fica roca, é issu á́. É mesma coisa qui era antis, cum mais facilidade de fica roca, é.

\section{$B=$ Não houve modificações na voz}

\begin{tabular}{|c|c|}
\hline EXPRESSÕES - CHAVE & DISCURSO DO SUJEITO COLETIVO \\
\hline $\begin{array}{l}\text { (4) Achu que continua a mesma coisa. } \\
\text { (5)... Mas de antes da menopausa pra } \\
\text { gora, eu num senti diferença. } \\
\text { (10) Num percebi si realmenti houvi algu, } \\
\text { assim num atinu assim, num cunsigu dicerni } \\
\text { si realmenti houvi. } \\
\text { (11) Eu creiu qui é igual era antis. } \\
\text { (12) Num sinti deferença, num sinti purque } \\
\text { eu tava cum aquele pobrema di voiz... } \\
\text { (14) Não, achu qui não teve modificação. } \\
\text { (16) .... Eu não, minha voiz não mudo } \\
\text { nada... nem pra canta. } \\
\text { (18) Quieu mi lembru não, ... Eu achu qui } \\
\text { não, achu qui continua senu a mesma. Na } \\
\text { minha opinião achu qui continua a mesma... } \\
\text { (20) A minha voz sempre foi a mesma. } \\
\text { (21) A voiz continua a mesma. }\end{array}$ & $\begin{array}{l}\text { Eu não senti diferença da minha voz de antes } \\
\text { da menopausa para agora. Acho que } \\
\text { continua a mesma coisa; não percebi se } \\
\text { realmente houve algo porque já estava com } \\
\text { problema de voz, então acho que não teve } \\
\text { modificação. Portanto, na voz não, na voz } \\
\text { não senti mudança nem para cantar, ela } \\
\text { sempre foi assim. }\end{array}$ \\
\hline
\end{tabular}


(22) Eu achu que não, achu que não... Continua como era antis. Não senti nenhum tipo di mudança...

(24) ... na voz não, na voz não senti...

(28) Não, pelu quieu sintu assim, não..... A minha voiz é sempre assim...

\section{C= Ponderações constituídas sobre a própria voz}

\begin{tabular}{|c|c|}
\hline & DISCURSO DO SUJEITO COLETIVO \\
\hline $\begin{array}{l}\text { (1) É, eu, eu dexei di ensa } \\
\text { cansaço, no geral... Eu tava } \\
\text { que mais o cansaçu físicu... P } \\
\text { gente ta lá naquele ensaio } \\
\text { sente cansaçu, você pode f } \\
\text { treis horas lá que num... } \\
\text { passa, é uma coisa maravill } \\
\text { eu to lá, porque eu sempre } \\
\text { televisão ligada... e tem aque } \\
\text { missionário Hebert Soares ... } \\
\text { então ali tem pregacões, te }\end{array}$ & $\begin{array}{l}\text { Voz feminina é aguda e fina. A voz } \\
\text { engrossada da menopausa, ou do } \\
\text { cigarro, parece de homem, } \\
\text { principalmente no telefone. Ela incomoda } \\
\text { tanto por esta confusão quanto por não } \\
\text { poder cantar mais em casa ou na Igreja } \\
\text { - para quem conseguia, não era } \\
\text { desafinada - e por representar que é } \\
\text { uma pessoa esquisita, muito feia. As } \\
\text { mudanças na voz podem ser produzidas } \\
\text { pelo calorão que exacerba o nervoso, } \\
\text { pela ansiedade e pela solidão daquelas } \\
\text { que moram sozinhas. Aparentemente se } \\
\text { vai ficando velha e a voz fica diferente, } \\
\text { algo acontece, porque se há emoção ou } \\
\text { uso freqüente da voz, aparece o pigarro, } \\
\text { que atrapalha, mas é bem diferente de } \\
\text { um calo nas pregas vocais; o tom } \\
\text { envelhecido da voz faz as pessoas } \\
\text { desconhecidas chamarem a gente de } \\
\text { senhora - apesar de que o jeito e os } \\
\text { assuntos de pessoas mais velhas } \\
\text { também serem outros da conversa de } \\
\text { um jovem - e as conhecidas passarem a } \\
\text { estranhar aquela voz. E acho também } \\
\text { que a gente chega em uma idade } \\
\text { sabendo dar mais valor às coisas, à vida, } \\
\text { e essa sensação é transmitida pela voz. } \\
\text { A menopausa ampliou minha } \\
\text { sensibilidade: dores, tontura, fraqueza, } \\
\text { cansaço físico e da voz, choradeira, } \\
\text { depressão, e aumentou o peso que } \\
\text { parece só diminuir com exercícios, } \\
\text { independente da quantia de alimentos, a } \\
\text { não ser que se passe somente com } \\
\text { água, trabalhando de oito a dezesseis } \\
\text { horas por dia. Algumas informações que }\end{array}$ \\
\hline
\end{tabular}


eli saí a voz limpa e saí grito forte... eu consigo faze isso, até mais que genti mais nova do que eu. Faço massage, se preparo e quando a ch... quando gente vai fala, abri bem a garganta... não dexa i trancandu.

(6) Hoji eu to achano ela mais cheia, assim pareci a voz ta mais... grossinha, num sei, eu acho qué devido a minha garganta mesmo. Até quieu... eu ia fala ... quem ove,.... mais quem escuta eu fala ai, quem vai ovi a gravação, fala " nossa que mulher isquisita, que muié mais feia, oh a voz dessa mulher", eu achu... muito feia.. qué dize, eu num so tão bunita, num so bunita, mais também num so tão feia, mais essa voz aí parece daquelas muié muito fea dimais...

(7) Eu acho que eu fiquei muito sensivel com a menopausa... Dor eu sei qui eu num tinha, agora to tendo... Qui nunca, num, num duia antes... Tontura..., eu nunca senti antes, to tendo tontura, mas também num to tomando nenhum medicamento queu acho qui ta certo ainda... pra mim melhora, purque eu não me sintu uma pessoa duente, eu acho que se eu toma um remédio que me faça bem, eu vo fica boa, purque trabalha qui nem eu trabalho... uma pessoa doent num trabalha qui nem eu trabalho ... a voz teria que melhora, eu acho... Teim essa fraqueza, essi cansaçu.... Ahh, às vezis eu tenho choradera de novo i eu achu queu to entrano em depressão.... eu não tinha a qua.. três mesis atrás eu num dava esses tipo de coisa.

(8) Não, pur cause qui.. quieu acho assim: sei sé purque a genti fica, a genti dá uma ansiedadi na genti, a veis quanu a genti fica deitado, ta durminu, acorda... "Será, meu Deus, queu to boa, será quieu vo se...qui vo te vô te uma melhora, será quiu vo fica melhor assim". Eu achu qui tem hora quieu mesmu sintu queu to, u momentu queu tô falano baxo, cumeçu alto, eu sintu aquela ruindadi assim, dai eu peço pra Deus, "oh Deus me ajuda queu num era assim"... Então.... eu sei queu to passanu pur algum pobrema, então, issu ai to passanu mesmu, to tem... ainda mais a genti qui mora sozinha, num tem cum quem cunversa, então, é pior pra genti ainda, tem hora queu cunverso até sozinha, dendi casa dai, mais faze o que... Eu num sei.. purque u motivu... Pur cause qui.., sei lá si a genti.. vai ficanu recebi sobre sintomas da menopausa, inclusive sobre voz, se concretizaram, outras não. Existem tratamentos com hormônios, até em adesivo para não prejudicar o fígado de quem toma outros remédios, mas os medicamentos também podem trazer mudanças como aumento de pêlos, voz de homem perpetuamente. Talvez tenha algum que faça a gente sentir-se melhor, incluindo a voz, apesar de eu não estar doente, porque trabalhar como eu trabalho nenhum doente consegue. $\mathrm{E}$ se tem como cuidar da voz grossa é melhor tratar, porque incomoda, pois mesmo falando baixo, igual a todos da família, tem hora que precisa forçar, principalmente se estiver deprimida. A falta de treino (ensaios, exercícios ou cuidados) para cantar, ou problemas de garganta podem prejudicar a voz. Às vezes, o que me incomoda não é a voz, mas os ruídos produzidos durante 0 sono, o que está sendo pesquisado, pois alteração na tireóide pode provocar isto. As mudanças ocorreram apenas no rosto em que as rugas e a flacidez se instalaram rapidamente ou só observaram alteração de criança para adulto. Outras alegam sempre falarem calmamente e em baixa intensidade, gostarem da sua voz, ou ainda ter uma voz forte, podendo gritar intensamente com a voz limpa, melhor do que pessoas mais novas. 
velha, ou sei lá o que qui conteci, aguma coisa ni mim aconteceu di a minha voiz, ...

(9) ... Ah, eu achu quiii, de repenti ééé, a genti chega numa idad' qui a genti sabe mais.. os valores das coisas... Qui antes os valores era um i agora a genti acha qui u valor é otru... Ai eu achu qui tudu issu a genti acaba transmitindo na voz... Qui a gente senti assim.. .. valor diferenti... a genti consegui medi as coisa assim.. ééé di uma outra forma... Que a genti acha... vê a vida assim um pocu diferenti com, com a idadi qui a genti ta... Qui antis u que na, não era muitu di valorizadu pra mim, hoji já valorizu mais... Eu achu qui é issu...

(11) Não! Eu num, não.., sabi quieu num coloqueei.., num ponhei essi nu pensamentu, eu não...

(13) ... Notu qui a genti vai ficanu di mais idadi... di certu vai modificanu, sei lá... agora a genti vai ficanu veia a voiz pareci qui fica meio diferenti... Ah, eu mi sintu assim...

(14) Ah, num tenhu comu fala, u qui fala... ...Eu achu que desdi minina até agora eu achu qui, sei lá, num mudei não. Nu meu pensamentu... nu meu vive, achu qui não...

(15) ... Igual de uma pessoa de mais idade, o jeitu di fala já não é qui nem uma pessoa mais jovem... Porque ce sabi, quandu às vezis assim... conversava cas pessoa assim por telefone... pessoas assim qui não conhecem a genti, chamava a genti de você... agora di uns tempu pra cá, tudo é senhora, senhora, dá a impressão qui.. pelu tom di voz qui eu envelheci bastanti... Ce pega o telefone é senhora, primeru era você... agora é senhora... Puxa, olha.... Agora já, u assuntu já muda totalmente... já não é qui nem quanu a genti tem menas idade...

(16) Inclusivi a genti ce sabi qui quando eu me operei, a primera veiz quieu fiz a operação de ováriu, eu tava saindu da anestesia iscutei uma prima minha quiela éé, te hoji ela é enfermera... ela falo pro meu.. meu companheru, qui nóis já se conhecia nessi tempu, "só vai ter um pormenor: vai ficar mais gorda (qui realmenti nunca mais pudi voltar u meu pesu quieu pesava quarenta e dois) ... ela vai fica mais gorda purque é qui nem um porco castradu (mi lembru tão bem quiela falo issu) e otra coisa, 
ela vai perde a, a sexualidadi...".. Aquilu me abalo, porque nós estávamos, éé, nós fazia pocos mesis qui se tinha se conhecidu, eu e eli... Aquilu, mais eu anestesiada, saindu da anestesia iscutei ela fala... "bandida, falo issu pra eli", sabi. Depois eu xinguei ela... depois dias depois eu xinguei ela. Aí elaaa... não mais nada dissu aconteceu... Aconteceu deu fica gorda, aumento o pesu e não tem como reverte, sieu como poco fico mema coisa, sieu como bem eu fico a mema coisa. Não tem, sabi, é engraçadu.. Podi se qui cum... caminhada, essas coisa qui eu sempri queru faze i nunca dá, podi se quieu voltu um poquinhu menus... Na lanchoneti, nu tempu quieu trabalhava, eu comecei a só toma muitu líquidu... líquidu que dize áqua mesmu, nem refrigeranti... qui tinha muita coisa ali, muita gordura, muita coisarada, intão dexei de ladu i comecei a toma muitu líquidu, hora quieu tava lá, quieu fazia oitu horas, tinha dias quieu fazia dezesseis horas... Intão, eu aí imagreci, imagreci, magrici, magrici mesmu... Tava até feiu, mais depois eu fui voltandu ao normal, daí eu fiquei muitu magra, as ropa caindu, até minha gerenti falo assim "ai... você ta tão feia assim, você tem u corpu tão bunitu...", qui eu tenhu sempri qui... "qui ta contecendu cum você, ce ta duent' ?" "não, não, a única coisa qui num to comendu essas... bobagerada ai $i^{\prime \prime}$ qui, sabi, saturada "i tomanu bastanti líquidu". Daí eu vi que tava meiu... Aí comecei novamente.. não cume quelas bobagerada, mais... leva um lanche de casa, um pão, dois i comecei novament a ingorda e no percu. Mais $u$ contrário ta tudu bem.

(17) ... Num sei se é pur causa du calorão... mais modifico um poco a minha voiz... Depois otra, a genti fica muitu nervosa... u calorão também ataca muitu us nervu da genti.

(19) Nunca consegui canta, nunca. Nem di mocinha. Eu cantu, mais é tudu desafinadu i tem uma coisa qui incomoda. Sempri, desdi moça durmu fazenu (faz sons de roncos no nariz e garganta) a noiti intera fazenu issu. Ela mando faze exami di sangui i no meu ixami di sangui hoji eu vo vê a tiróidi.

(21) Eu achu quieu era assim, purque eu sempri gostei di fala calma assim, num pricisu di grita nem nada... 


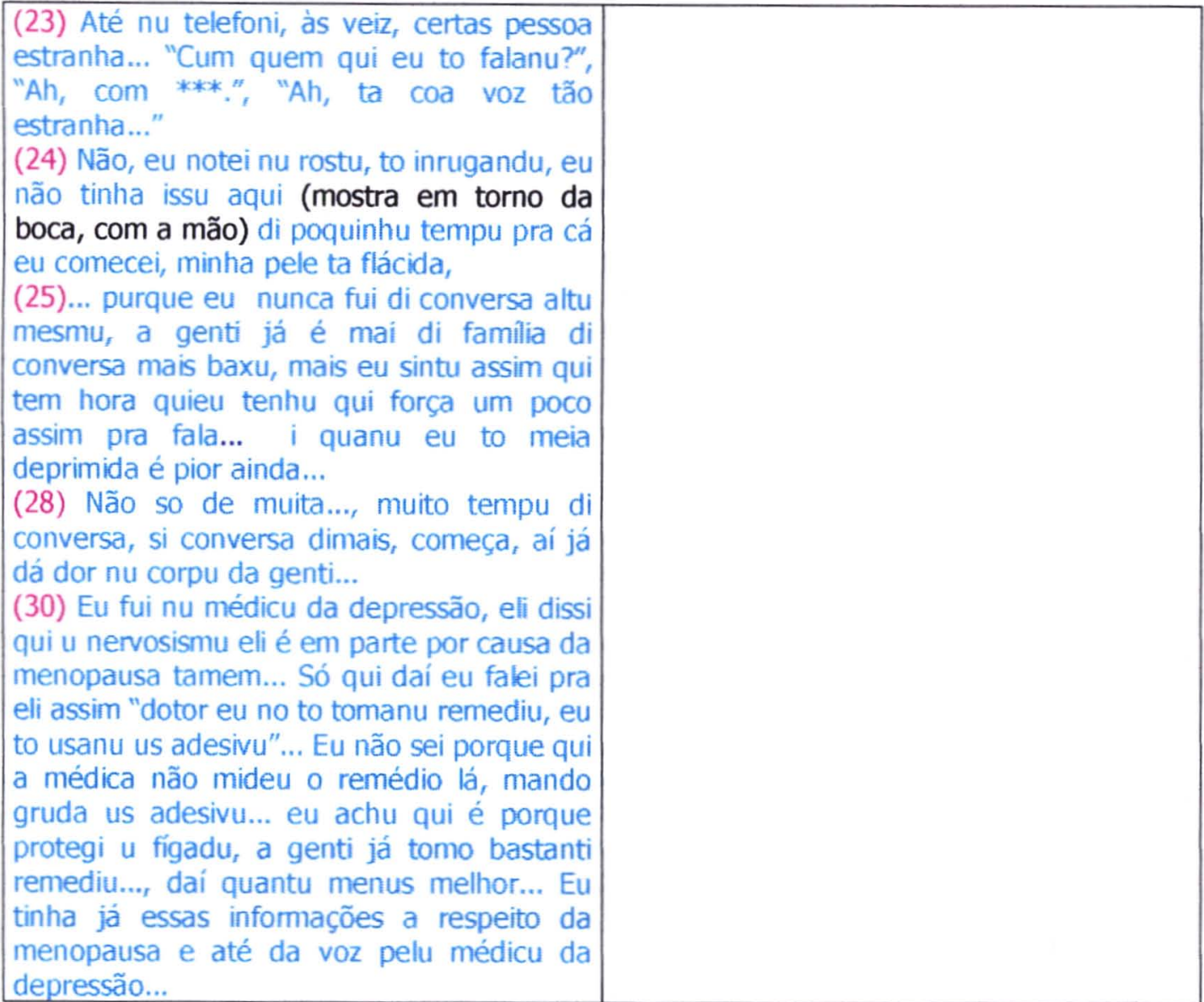

D = Ponderações constituídas sobre a voz dos outros

\section{EXPRESSÕES - CHAVE}

DISCURSO DO SUJEITO COLEIIVO

(5) Eu leiu revista.., escutu a reportagem... Eu leio revistas, escuto reportagens, vi minha eu vi a minha a mãe, eu vi pessoas mais velha, eu já vi que tem pessoas mais velha que vai.. as vezes mesmu quando a gente tava no grupo na igreja que ia canta, tem pessoas que a gente quiria voz... pessoas mais velha, eu sentia queles apertava garganta... Então eu já vo preparano a minha... eu sei que faze o que é bom de faze..., num vo espera ta precisano já pra faze... Já vo evita que aconteça ... Ah, a gente vê que sim... as otra pessoa você prestanu tenção você, você percebi que, que vai mudano, mais eu já por isso já vo adiantando... Daí eu sei que isso pudera contece, eu já.. quero evita que acunteça cumigo. Quando aperta a garganta ela sai uma voz apertada... Uma voz chiada...., não sai aquela voz limpa, voz forte, se vê que tem mãe e outras pessoas mais velhas que cantavam e percebo que a voz vai mudando. Quando os idosos apertam a garganta para cantar sai uma voz chiada, apertada, fraca, suja, parecendo estar com algo engasgado na garganta. Então, eu sei que isso poderá acontecer comigo e me preparo. Eu tenho uma irmã que, dizem, depois de descer a menstruação ficou rouca para sempre por ter tomado uma chuva. Tenho também uma colega que tomou uma medicação e a sua voz mudou. Ela tinha que fazer depilação no rosto, mas hoje não precisa mais, porque a idade vai amortecendo a necessidade. 
parece que tem alguma coisa engasgada na garganta...

(12) Eu tenhu uma irmã qui depois da menstruação ela fico bem roca tamém. Depois qui veio... ela deu um pobrema assim quela, elis falum qui fooi uuma chuva qui ela tomo ela fico bem roca, duma chuva qui ela tomo... Aí ela fico bem roca, mais fico roca pra sempre, nunca mais trato... Não, quando veiu, é ... é quandu desceu a menstruação, intão a gent tinha aquele custume di nãão banha cabeça... e ela tomo aquela chuva duma veiz, aí ela roco. Agora num fala qui foi issu, num sei...

(16) Tinha uma colega minha quiela tevi uns poblema seríssimu, ela mudo a voz dela, queria qui ce visse, mudo, até hoje é mudada, a voz dela num é aquilu. Ela fico cuma voz de homem, ce credita? Ela tem, tinha pêlo tudu assim, assim no rosto dela, assim incrivel... ...essa minha colega, nós trabalhávamos juntus te hoji a genti tem amizade, ela mudo completamenti a voz dela. Ela tinha que faze depilação no rosto.... de tantu em tantu tempu... agora não, porque agora com a idadi já vai ..amortecenu um poucu... mas a voz dela continua mema coisa.

\section{Ancoragem}

\section{$A=$ Menstruada, tomar chuva deixa rouca}

\begin{tabular}{|l|l|}
\hline \multicolumn{1}{|c|}{ EXPRESSŐES - CHAVE } & \multicolumn{2}{|c|}{ DISCURSO DO SUJEITO COLETIVO } \\
\hline $\begin{array}{l}\text { (12) Depois qui veio... ela deu um pobrema assim quela, } \\
\text { efas fafum qui fooi uuma chivva qui ela tomo ela fico bem } \\
\text { roca, duma chiuva qui ela tomo... }\end{array}$ & $\begin{array}{l}\text { As pessoas que moram na zona rural dizem } \\
\text { que não pode tomar chuva estando } \\
\text { menstruada. Isso pode deixar rouco para } \\
\text { sempre. }\end{array}$ \\
\hline
\end{tabular}




\section{ANEXO III}

\section{Termo de Compromisso Ético}

Alicerçada na Resolução 196/96 do Conselho Nacional de Saúde e nas Normas Éticas Internacionais para Investigações Biomédicas com Seres Humanos - CIOMS 1996, foram obtidos os seguintes critérios :

A população será constituída de mulheres consideradas como autônomas; capazes legalmente e não-vulneráveis. A participação na pesquisa será voluntária e consistirá em responder a um roteiro temático, que contem questões pessoais e opinativas a respeito dos assuntos voz e menopausa.

As entrevistas serão realizadas em ambiente propício e individualmente, sem a presença de outras pessoas, conservando a privacidade e a confidencialidade no ato da mesma. Serão gravadas e transcritas, havendo garantia de cuidado e respeito com as informações e material constante, preservando a identidade da entrevistada através da utilização de nomes fictícios.

Após serem informadas dos objetivos e procedimentos da pesquisa, será apresentado um termo de consentimento livre e esclarecido (ANEXO IV) para ser assinado.

Será assegurada a liberdade de recusa ou de desistência em qualquer momento da investigação sem que isso implique prejuizos ao atendimento no serviço ambulatorial. 


\section{ANEXO IV \\ CONSENTIMENTO LIVRE E ESCLARECIDO}

Fui informada previamente a respeito da pesquisa realizada no Programa de Saúde da Mulher no Climatério, do setor de Ginecologia da Santa Casa de Misericórdia de Curitiba, Paraná, e que consistirá em responder questões pessoais acerca dos assuntos voz e menopausa.

Fui esclarecida que a entrevista será gravada e que o material utilizado e as informações obtidas serão mantidos em condições de respeito e preservação da minha identidade em todas as esferas em que a pesquisa for apresentada. Foi explicado também que posso não aceitar ou desistir sem que isso interfira no atendimento do serviço de saúde.

Assinatura da entrevistada

Data

Contato com a responsável pela pesquisa: Fga Maria Aparecida M. P. Machado Telefones - (041) 320-3524 às segundas- feiras

(011) 3066-7702 / 3066-7703 / 3066- 7773

Orientador da pesquisa: Prof. Dr. João Yunes/ Dr. José Mendes Aldrighi

Departamento de Saúde Materno Infantil

Faculdade de Saúde Pública

Universidade de São Paulo 


\section{UNIVERSIDADE DE SÃO PAULO \\ FACULDADE DE SAÚDE PÚBLICA \\ COMITÉ DE ÉTICA EM PESQUISA-COEP \\ Av. Dr. Arnaldo, 715 - Cerqueira César \\ São Paulo-SP - CEP: 01246-904 \\ Telefone: (0xx11) 3066-7779 - e-mail: mdgracas@usp.br}

\section{Of.COEP/061/01}

16 de maio de 2001

Pelo presente, informo que o Comitê de Ética em Pesquisa da Faculdade de Saúde Pública da Universidade de São Paulo-COEP, analisou e aprovou, em sua 4.\%/01, Sessão Ordinária, realizada em 15.05.2001, de acordo com os requisitos da Resolução CNS/196/96, o Protocolo de Pesquisa n. ${ }^{\circ} 459$, intitulado: "A VOZ DAS MULHERES NA PÓS-MENOPAUSA", apresentado pela pesquisadora Maria Aparecida Miranda de Paula Machado.

Atenciosamente,

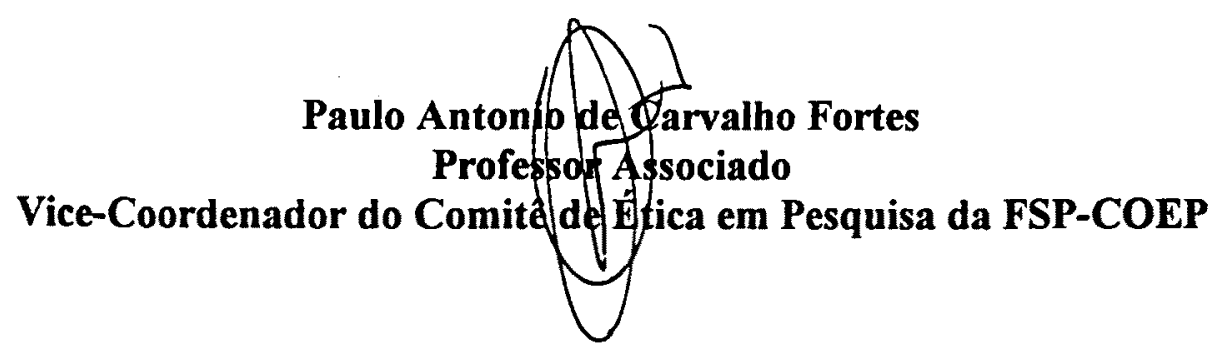

